\title{
The Insurgent's Dilemma: A Theory of Mobilization and Conflict
}

\section{Outcome}

\author{
By
}

Eric Jardine

A thesis submitted to the Faculty of Graduate Studies and Postdoctoral Affairs in Partial Fulfilment of the Requirements for the Degree of

Doctor of Philosophy

in

International Affairs

\author{
Carleton University \\ Ottawa, Ontario
}

(C) 2014

Eric Jardine 
Abstract (310): Why do some rebel groups win while others lose? Current explanations for why the outcomes of insurgencies vary tend to either overlook the role that the population plays in supporting an insurgency or fail to specify how the requirements of a rebel group's mobilization of popular support might have their own effect on conflict outcome. In this dissertation, I develop a theory of conflict outcome that links a rebel group's mobilization of popular support to organizational and administrative reforms, which, in turn, affect an insurgency's chances of winning or losing. I argue that all rebel groups face a core "Insurgent's Dilemma." On the one hand, insurgent groups often need to become organizationally centralized and have a large-scale administrative presence in order to mobilize a large amount of popular support, because with higher levels of popular support comes a greater chance of defeating a regime. Yet the same organizational and administrative characteristics that allow for effective mobilization actually favour the state in its efforts to destroy an insurgency. On the other hand, an insurgency can abjure centralization and a large-scale presence and avoid adopting characteristics that favour the state's counterinsurgency efforts. Doing so, however, limits the amount of popular support that an insurgency can ultimately mobilize, which effectively means that the group is unlikely to succeed, even if it is hard to defeat. Throughout the development of the mobilization and conflict outcome theory, I substantiate each point with qualitative historical evidence from a number of insurgencies. I also explicitly test three hypotheses that are derived from the theory using descriptive statistics from 21 insurgencies. Finally, I test the proposed mechanisms 
Jardine, 3

against four cases (the Mau Mau in Kenya, the Shining Path in Peru, the Mujahideen in Afghanistan, and the EPLF in Eritrea). 


\section{Table of Contents}

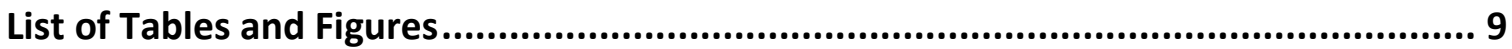

Table 6.3. Incidents and Deaths by Month, April 1992-March 1993. 297 .10

Acknowledgements .12

Chapter 1: Introduction to the Insurgent's Dilemma .................................................13

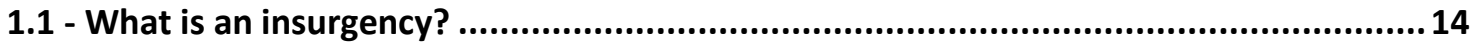

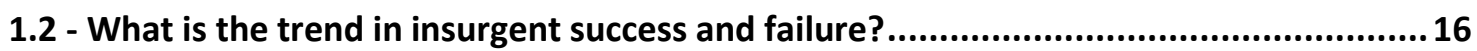

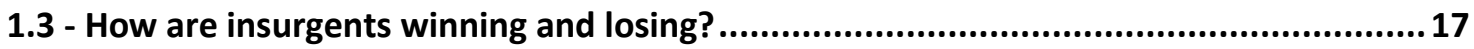

1.4 - What are the current explanations of Rebel Group Success and Failure and what do

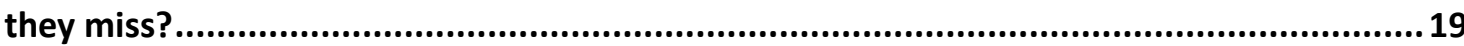

1.4.1 - The Social Scientific Explanations: Strategic Interaction, Counterinsurgent Force

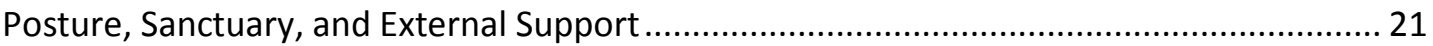

1.4.2 - The Illuminating Practical Work on Waging Insurgency ........................................... 33

1.4.3 - Conclusions on the Social Scientific Explanations and the Thoughts of Practitioners 38



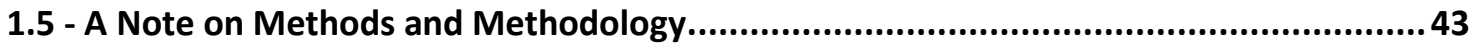

1.5.1 - Part 1, The "Discovery Stage": Building a Theory of Mobilization and Conflict



1.5.2 - Part 2, The "Appraisal Stage": Testing the Theory against Empirical Evidence........... 45



1.6 - A Summary of The Mobilization and Conflict Outcome Theory and Chapter Outline ...49

Chapter 2: Insurgency and Popular Support

2.1 - Popular Support for an Insurgency: What is it, How does it Manifest, Why Does it Matter? .57

2.2 - How much popular support will an insurgency need? .62

2.3 - How do Insurgent Organizations Obtain the Support of the Population? .69

2.3.1 - Method 1: Providing Remunerative Compensation to the Population in Exchange for Support

2.3.2 - Method 2: Manipulating the Preferences of the Population through Coercion and

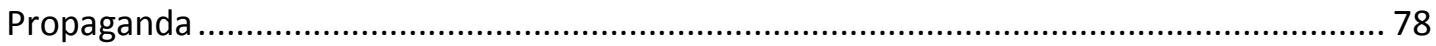

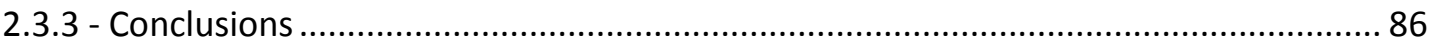

2.4 - What role does the state play in the population-insurgent group exchange

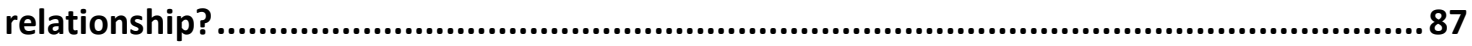

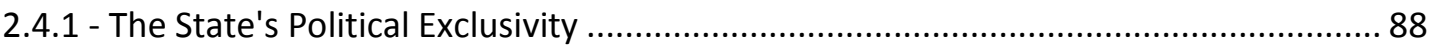

2.4.2 - The State's Use of Indiscriminate Violence................................................................ 92

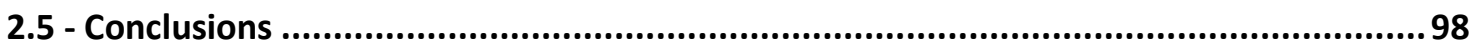




\section{Chapter 3: The Structural Characteristics of Insurgent Groups and Organizational} Growth

3.1 - How can an insurgent group grow in size so as to bridge the gap between its current amount of mobilized popular support and the quantity of popular support that it needs to effectively challenge the regime?

3.2 - How can an insurgency produce enough popular support-securing outputs to obtain growth?

3.2.1 - Defining Economies of Scale and Insurgent Group Administrative Presence

3.2.2 - An Expanded Profit Margin Model: Rebel Group Administrative Presence and Quantity Produced.

3.2.3 - Marginal Tradeoffs: Military Versus Administrative and Depth Versus Breadth ..... 116

3.2.4 - Expanding Administration and the Generation of Economies of Scale .................... 119

3.2.5 - Expansion Via Wholly-Original Organization Building ........................................... 120

3.2.6 - Expansion Via the Incorporation of Pre-Existing Socio-Political Organizations........ 123

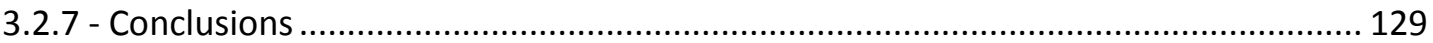

3.3 - What rebel group organizational structure leads to the highest growth potential? ... 130

3.3.1 - Some Definitions: Variable Costs, Production Efficiency, and Organizational Centralization

3.3.2 - An Expanded Profit Margin Model: Rebel Group Organizational Centralization and Variable Costs

3.3.3 - Production Process Costs and Rebel Group Efficiency ......................................... 135

3.3.4 - Decision-Making Costs, Hierarchy, and Organizational Centralization

3.3.5 - Coordination Costs, Coordination Mechanisms, and Organizational Centralization 142

3.3.6 - Opportunity Costs, Organizational Specialization and Organizational Centralization148

3.3.7 - Agency Costs, Monitoring and Compliance Mechanisms, and Organizational

Centralization

3.3.8 - Some General Relationships: Organizational Centralization, Group Size, and Group

Productive Efficiency.

3.3.9 - Conclusions

3.4 - Conclusions 166

Chapter 4: The Interaction of the State and the Insurgency 168

4.1 - How does the scale of an insurgent group's administrative presence affect its vulnerability to state action?

4.1.1 - Administrative Presence and Rebel Group Mobility

4.1.2 - Administrative Presence and the Contrast Between the Population and a Rebel

Group's Organization and Infrastructure.

4.1.3 - Some General Relationships between Rebel Group Administrative Presence, Rebel

Group Vulnerability, and the Rebellion's Capacity Relative to the State 183

4.1.4 - Conclusions 188

4.2 - How does the degree of an insurgency's organizational centralization affect its resiliency to state military action? 
4.2.1 - Organizational Resilience and Subunit Mutual Reliance: Centralization and CoDependence, Decentralization and Autonomy. 190

4.2.2 - Centralized Groups: Mutually Reliant and Lacking in Resilience .............................. 191

4.2.3 - Decentralized Groups: Lacking in Mutual Reliance but Highly Resilient .... 194

4.2.4 - Total Group Resilience as a Product of Both Organizational Form and Relative Capacity 199

4.2.5 - Contest Success Functions: An Overview 200

4.2.6 - A Modified Contest Success Function: State Offensives, Rebel Group Resilience, and Rebel Attrition. 200

4.2.7 - Vietnam and Malaya: Empirical Examples of the Conflict Success Function and Attrition Curve 209

4.3 - Conclusions 216

Chapter 5: Why do some rebel groups win and others lose? .218

5.1 - What is the General Relationship between an Insurgent Group's Mobilization of Popular Support and Conflict Outcome?

5.2 - If the theory is correct, what should we expect to see across multiple insurgencies? 230

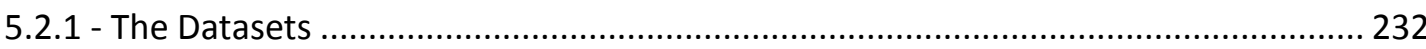

5.2.2 - Hypothesis 1: The State Should Almost Always Win .............................................. 234

5.2.3 - Hypothesis 2: The Relationship between A Rebel Group's Mobilized Capacity and State Success Should be Positive so Long as the Insurgency is Weaker

5.2.4 - Hypothesis 3: High Levels of Absolute Mobilization Require Centralization and an Expansion of a Rebel Group's Administrative Presence .................................................. 245

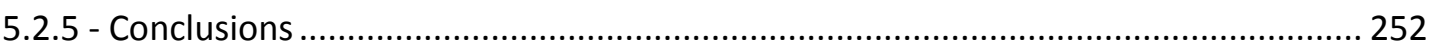

5.3 - What factors, as suggested by the theory, affect conflict outcome? .......................... 252

5.3.1 - Will a Rebel Group Lose Before it Can Win? How Conditions Affect the Slope of the

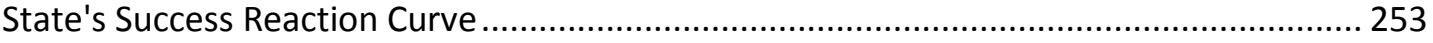

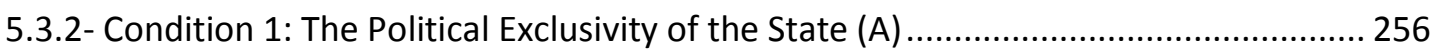

5.3.3 - Condition 2: The State's Use of Indiscriminate Repression (B).................................. 257

5.3.4 - Condition 3: Expansion of a Rebel Group's Administrative Presence by Incorporating

Pre-Existing Socio-Political Networks (C) ...................................................................... 258

5.3.5 - Condition 4: External Support for an Insurgency (Illicit Crops, Lootable Resources,

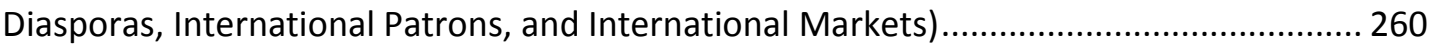

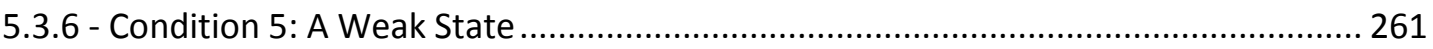

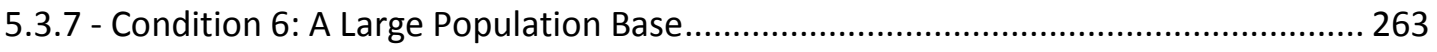



Chapter 6: Evidence on the Mechanisms from Four Types of Insurgencies................266

6.1 - A Typology of Rebel Groups: Administrative Presence and Organizational

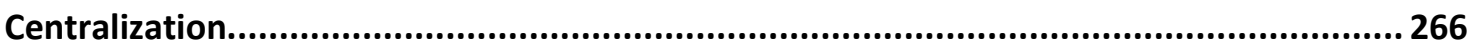

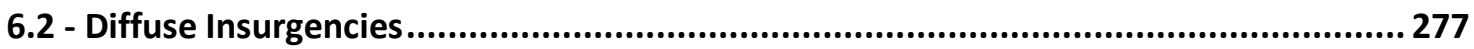

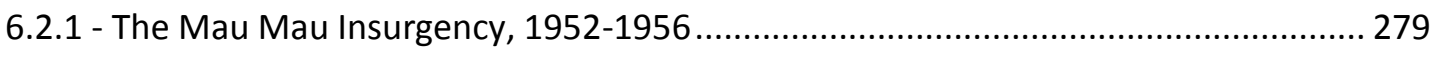

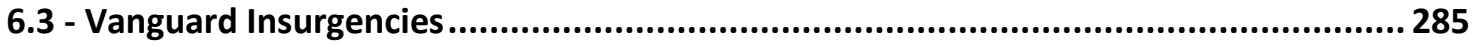




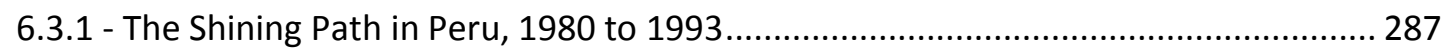

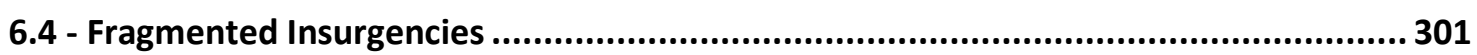

6.4.1 - The Afghan Mujahideen against the Soviets, 1978-1989 .......................................... 304

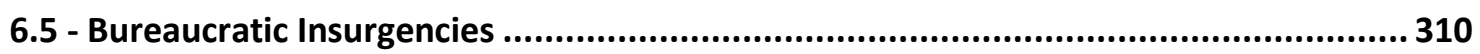

6.5.1 - The Eritrean People's Liberation Front in then-Ethiopia .......................................... 312

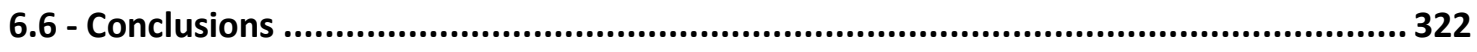

Chapter 7: Some Brief Conclusions............................................................323 
Jardine, 8 


\section{List of Tables and Figures}

Figure 1.1. The 200 Year Trend in State Success and Failure Against Insurgencies

Figure 1.2. A Possible Causal Relationship Between Mobilization, Popular Support, and Conflict

Outcome.

Figure 2.1. The Insurgency's Exchange of Services and Goods for Popular Support. 76

Figure 2.2. The Insurgency's Manipulation of Popular Preferences Through Coercion and Propaganda. .82

Figure 2.3. The State's Exclusionary Politics and the Population's Preference for Rebellion.

Figure 2.4. The State's Use of Indiscriminate Repression and the Preferences of the

People.

Figure 3.1. Insurgent Group Mobilization Context, Group Structure, and Organizational Growth or Decline

Figure 3.2. An Insurgency's Investment in Administrative Presence and Group Growth

Figure 3.3. Insurgent Group Administrative Presence and the Average Cost per Unit of Production.

Figure 3.4. Investment in Centralization and Group Growth.

Figure 3.5. Increasing Organizational Centralization and the Costs of

Production.

Figure 4.1. Rebel Group Administrative Presence and Group Vulnerability Conditioned by The Relative Capacity of the State and the Insurgency..... .185

Figure 4.2. Subunit Mutual Reliance and Organizational Decentralization and Centralization. 190

Figure 4.3. The State's Offensive Contest Success Function and a Rebel Group's Relative Capacity and Organization. .205 
Table 4.1. Insurgent Size, Attrition, and Replacement in Malaya

Figure 5.1. Rebel Group Relative Capacity and Chance of State Victory. .223

Figure 5.2. The State's Success Rate Against Insurgent Groups in Limited Autarky....235

Table 5.1. Insurgencies without External Support. $240-241$

Figure 5.3. Rebel Group Relative Capacity Under Autarky. .243

Figure 5.4. Rebel Group Relative Capacity and State Success under Limited Autarky.244 Figure 5.5. The Prevalence of Hierarchies and Networks by Group Size Under Limited Autarky. .250

Figure 5.6. Rebel Group Administrative Presence and Absolute Size Under Limited Autarky. .251

Figure 5.7. Rebel Group Relative Capacity and Chance of State Success Under Variable Conditions. .255

Table 6.1. A Typology of Rebel

Organizations. 267

Table 6.2. Operational Measures of Rebel Group Organizational Centralization and Administrative

Presence .271

Figure 6.3. Diffuse

Insurgencies .278

Figure 6.4. Vanguard Insurgencies. .286

Table 6.3. Incidents and Deaths by Month, April 1992-March 1993. .300

Figure 6.4. Fragmented Insurgencies .303

Figure 6.5. Bureaucratic Insurgencies. 
Jardine, 11 


\section{Acknowledgements}

My research has been generously supported by a number of organizations and individuals. Carleton University, the Norman Paterson School of International Affairs, and the Centre for Security and Defence Studies have provided me with a home for the last 5 years. The former Security and Defence Forum, the Ontario Graduate Scholarship fund and the Social Sciences and Humanities Research Council have all provided me with funds to conduct my research. The members of my supervisory committee, Fen Hampson, Jez Littlewood, and Dane Rowlands, have provided much needed advice and guidance throughout the process. This work could not have been completed without their tutelage.

My parents, academics themselves, have encouraged me every step of the way. Many of my friends have listened while I talked at them about my research. Some select individuals, notably Simon Palamar, Theo McLaughlin, Josh Kilberg, Marc Tyrrell, and, in particular, Jennifer Dumoulin, have read my work and given me much needed guidance and advice. Needless to say, the mistakes that remain are my fault alone. 


\section{Chapter 1: Introduction to the Insurgent's Dilemma}

Even the most cursory observation of the numerous civil wars that have occurred around the world indicates that a rebel group's success or failure is not preordained. Some insurgent groups defeat the states that they are challenging, as was the case with the Vietcong in Vietnam, the Eritrean People's Liberation Front (EPLF) in Eritrea, the National Liberation Front (FLN) in Algeria, and Fidel Castro's M26 movement in Cuba. Other rebel groups, such as the Liberation Tigers of Tamil Eelam (LTTE) in Sri Lanka, the Malayan Communist Party (MCP) in Malaya, the Huks in the Philippines, and the Tupamaros in Uruguay, lose. This variation in the outcome of rebel movements begs an obvious question: why do some insurgent groups win while others lose?

In my dissertation, I answer this question by developing a theory of rebel group success and failure that emphasizes how an insurgency' mobilization of popular support affects both its organizational development and conflict outcome. In particular, I argue that how an insurgent group organizes, both structurally and administratively, in order to mobilize higher levels of popular support can actually improve the odds that the state can defeat an insurgency, at least up until the insurgency becomes stronger than the regime. This claim provides some much needed nuance to the classical notion that popular support is necessary for successful rebellion.

In this introductory chapter, I first offer a definition of insurgency. I then layout the trend in insurgent group success and failure over the last 200 years. Next, I specify how insurgent groups tend to win or lose. Following that, I review current explanations 
for insurgent group success and failure. I argue that many of the best social science explanations of conflict outcome make largely untenable assumptions about the behaviour of the population within a country in conflict. I also argue that many of those works written by practitioners of insurgency, while highlighting the importance of popular support to successful rebellion, erroneously amalgamate the process by which an insurgency actually mobilizes support and an insurgency's possession of the support of a population. These are, I posit, analytically distinct elements with different effects on conflict outcome. After reviewing the literature, I discuss the methodology that I employ in the various parts of my dissertation. Lastly, I outline what I call the mobilization and conflict outcome theory and provide a breakdown of how the various chapters unfold.

\section{1 - What is an insurgency?}

In my study, I rely upon a somewhat older, but nevertheless prescient, Central

Intelligence Agency definition of insurgency:

Insurgency is a protracted political-military activity directed toward completely or partially controlling the resources of a country through the use of irregular military forces and illegal political organizations. Insurgent activity--including guerrilla warfare, terrorism, and political mobilization, for example propaganda, recruitment, front and covert party organization, and international activity--is designed to weaken government control and legitimacy while increasing insurgent control and legitimacy. The common denominator of most insurgent groups is their desire to control a particular area. This objective differentiates insurgent groups from purely terrorist organizations, whose objectives do not include the creation of an alternative government capable of controlling a given area of country. ${ }^{1}$

\footnotetext{
${ }^{1}$ This definition is from the Central Intelligence Agency's Guide to the Analysis of Insurgency, cited in, Daniel Byman, Peter Chalk, Bruce Hoffman, William Rosenau, and David Brannan, Trends in Outside Support for Insurgent Movements (Santa Monica: RAND Corporation Publishing, 2001), 4-5. Emphases added.
} 
I chose this definition of insurgency because it provides a clear statement on the common means and motives of insurgent groups, as well as some criteria that allow for distinctions to be drawn between insurgent groups and terrorist organizations. ${ }^{2}$ The three italicized portions of this definition outline the general boundaries of an insurgent group as they pertain to my study, particularly as it differs from its closest cousin, a terrorist organization. First, as noted in the cited passage, insurgents aim to control the resources of a country, which is often, in theory at least, the exclusive domain of the state. This aspect of the definition of insurgency places the rebel group and the state on a direct collision course, although this is not to say that there might not be other political actors in a country that also aim to control resources. The second italicized portion specifies the means that an insurgency can use to obtain control of the resources of a country, including most prominently, terrorism and guerrilla warfare, as well as political mobilization. These means are not exclusive to insurgent groups, but insurgent groups do use these tactics. The final italicized portion is, perhaps, the most important, as it draws the clearest boundary between rebels and terrorists. Insurgent groups aim to control and govern territory, be it a portion of a country, as in a secessionist conflict, or a whole country, as in the case of a nationalist insurgency. This final element most clearly differentiates insurgent groups from terrorist organizations, as the latter aim to obtain policy reform, but do not necessarily desire to control and govern territory. ${ }^{3}$

\footnotetext{
${ }^{2}$ It is also important to note that I use rebel group, insurgent group, insurgency, insurrection and guerrilla to mean the same thing. Each means the non-state actor that conforms with the definition provided that challenges the government of a country. I also use counterinsurgency, counterinsurgent, regime, and state to mean the same thing. Each captures the incumbent authority that is challenged by an insurgency. ${ }^{3}$ Certainly, some organizations that are usually called terrorist groups, such as Hamas or the Shining Path, aim to control and administer territory. Such groups would effectively be insurgent groups according to my definition. According to my definition, insurgent groups is a larger, but still clearly defined, category and terrorist groups is a smaller category. Some groups like Al-Qaeda span that divide, depending upon
} 


\section{2 - What is the trend in insurgent success and failure?}

Understanding the trend over time in the outcome of civil wars is important because any satisfying explanation of why some groups win and other lose needs to be able to account for the pattern in outcomes over time. If a theory cannot provide a satisfactory explanation for large macro-historical trends, its utility is somewhat lessened.

The trend in insurgent group success and failure is not what one might think. Intuitively, one would expect that the state, being bigger, stronger, and better established, should be able to defeat insurgent challengers, who are weaker, smaller, and initially unknown to the population, most of the time. However, the empirical record of state success and failure is far more mixed than this view would suggest. Prior to the end of the First World War, the state did indeed win most of the conflicts that it fought against rebels. Looking at conflicts between 1920 and 2002, the trend has actually reversed itself, with insurgent groups winning more than 50 percent of the time. For example, between 1800 and the end of World War I, insurgents that faced Great Powers were defeated 81 percent of the time. Likewise, rebels that faced non-great powers lost 80 percent of the time. Since 1919, however, the trend has changed considerably, with great powers defeating rebel groups only 40 percent of the time and non-great powers defeating insurgent challengers only 33 percent of the time. ${ }^{4}$

\footnotetext{
whether you look at the core or the franchises. For a review of terrorist strategies, see Andrew H. Kydd and Barbara F. Walter, "The Strategies of Terrorism," International Security, Vol. 31, no. 1 (2006), 49-80. ${ }^{4}$ These percentages are taken from Jason Lyall and Isaiah Wilson III, "Rage Against the Machines: Explaining Outcomes in Counterinsurgency Warfare," International Organization, Vol. 63, no. 1 (2009), 6970. Lyall and Wilson code draws as a win for the state.
} 


\section{Figure 1.1. The 200 Year Trend in State Success and Failure Against Insurgencies}

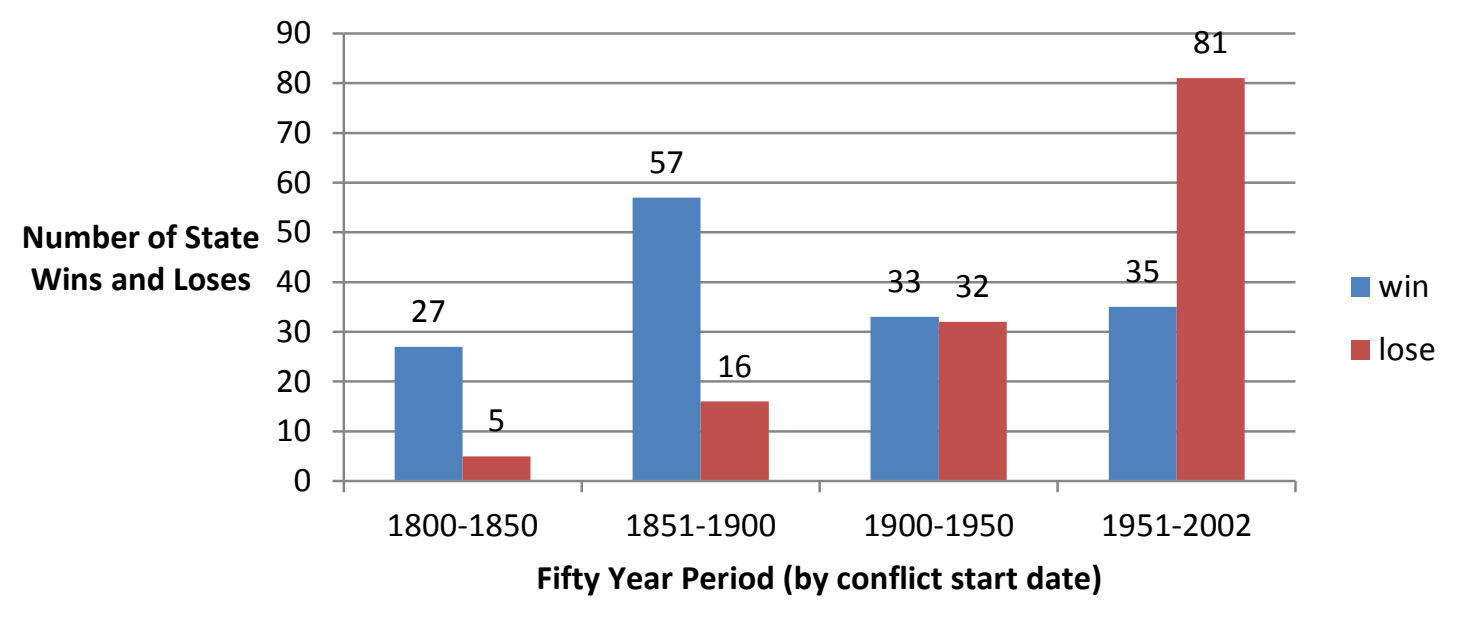

Figure 1.1 presents a histogram of the 200 -year trend is state success and failure against all insurgencies. ${ }^{5}$

What this means is that any theory of why some rebel groups win and others lose needs to be able to explain - or at least be generally in line with - this long term historical trend. Any theory of conflict outcome during civil war, therefore, needs to be able to answer the question of why insurgencies win far more often than they did in the past.

\section{3 - How are insurgents winning and losing?}

In addition to knowing the frequency with which rebel groups are winning and losing over time, it is also important to have some sense of how such conflicts unfold. The literature on internal wars and insurgencies suggests that military force plays a key role in

\footnotetext{
${ }^{5}$ Data for this figure is drawn from Lyall and Wilson III dataset, Correlates of Insurgency. More detailed discussion of the Correlates of Insurgency dataset is found in chapter 5. Jason Lyall and Isaiah Wilson III, "Rage Against the Machines: Explaining Outcomes in Counterinsurgency Warfare," International Organization, Vol. 63, no. 1 (2009), 69-70. Lyall and Wilson code draws as a win for the state.
} 
determining the outcome of a civil war. ${ }^{6}$ According to the Department of Defense Analysis' Internal Wars Database, there have been 243 insurgencies started and ended between 1945 and $2006 .^{7}$ One hundred and twelve of these cases, or roughly 46 percent of all insurgencies, have what appears to be a negotiated outcome. However, McCormick, Horton and Harrison find that only 20 percent of these cases, or 47 insurgencies total, were actually ended by a substantive negotiated settlements. In the rest of the cases, the negotiated settlement reified the wins and losses that had already been determined through the use of force on the battlefield.

Digging into the circumstances of these 47 cases, the authors find that in 17 percent ( 8 cases), a faction broke away from the insurgency and continued fighting. In 36 percent (17 cases) of these cases, the state and an internal challenger reached an agreement, but the conflict continued between the regime and some other insurgent group. The authors conclude that only 47 percent ( 22 cases) of the 47 substantive negotiated outcomes to internal wars have actually led to a lasting peacetime settlement. ${ }^{8}$ As a percentage of the total number of internal wars between 1945 and 2006, this finding entails that substantive negotiated settlements account for only 9.4 percent of outcomes. In the remaining 212 or upwards of 90 percent of the cases, the use of force played a decisive role in determining the outcome of the conflict, either leading to a solid victory by one side or the other or leading to a stalemate that was then reified in a negotiated agreement.

\footnotetext{
${ }^{6}$ This discussion is drawn from Gordon H. McCormick, Steven B. Horton, and Lauren A Harrison, "Things Fall Apart: The Endgame Dynamics of Internal Wars," Third World Quarterly, Vol. 28, no. 2 (2007), 321367.

${ }^{7}$ The Internal War database uses a fairly low threshold of 25 battle deaths for inclusion in the sample. See Ibid., 324.

${ }^{8}$ Ibid., 324-325.
} 
Empirically, this trend in how internal wars and insurgencies end means that any study of why some rebel groups win and others lose should focus on the drivers of the effective use of force during the conflict. Focusing on the use of negotiations, mediation, or other forms of non-violent conflict resolution, while useful in its own right and appealing on moral grounds, does not focus in on a very large part of the broader empirical pattern of internal war endings. Providing a clear theoretical explanation for why some rebel groups win and others lose that focuses on what drives the effective use of force explains a larger portion of the empirical record. Indeed, one primary aim of good social science is theoretical generality. As John Gerring puts it, "If the fundamental purpose of social science is to tell us about the world, then it stands to reason that an inference informing us about many phenomena is, by virtue of this fact, more useful than an inference pursuant to only a few phenomena." ${ }^{9}$

\section{4 - What are the current explanations of Rebel Group Success and Failure and what do they miss?}

With a topic as broad as why some rebel groups win and others lose, it is not surprising that there are several explanations for this phenomenon already in the literature. My review of this literature is divided into three parts. In one, I review the social scientific explanations of conflict outcome. In the second, I review the practical literature on insurgency. ${ }^{10}$ In the third section, I briefly discuss three studies that consider how rebel

\footnotetext{
${ }^{9}$ John Gerring, Social Science Methodology: A Unified Framework (New York: Cambridge University Press, 2012), 61.

${ }^{10}$ By distinguishing the literature into social scientific explanations and practical accounts, I do not mean to imply that one type of literature is any better than the other. They are crafted for different purposes and so I consider them in different sections.
} 
groups organize themselves and how differing organizational structures affect various elements of their behaviour.

The best social scientific explanations of variation in conflict outcome pinpoint important covariates of rebel group success and failure. I argue that each of these theories overlooks the central role that the population of a contested country plays in either sustaining or condemning a revolt. What is problematic is that each of the theories assumes, to varying degrees, that the population is generally supportive of the rebellion. Since the support of the population is itself highly variable, it simply cannot be assumed. Theories that do assume the support of the population likely overlook, I argue, a very important driver of how a conflict unfolds. Ultimately, these theories also incorrectly specify the drivers of conflict outcome by ignoring the amount of popular support controlled by a rebel group.

I also review some of the best practical guides to insurgency, written by insurgents themselves. While these works correctly emphasize the importance of popular support for a rebel group to effective insurgency (and counterinsurgency for that matter), I argue that they fail to distinguish between a rebel group's command of a given level of popular support and the processes and requirements of mobilizing that support. These two concepts are usually blended together, but they are actually analytically distinct phenomenon. As I show in more detail throughout this section, what an insurgent group has to do to mobilize popular support can actually be detrimental to an insurgency's chances of success, even if having more popular support is, itself, a good thing for an insurgency. 
In the literature on rebel group organization, I find that the focus of each study is primarily on explaining why different rebel groups organize differently. While some of the studies then connect a particular form of organization to various tasks that an insurgency can undertake, none of them directly considers how organization affects conflict outcome.

\subsection{1 - The Social Scientific Explanations: Strategic Interaction, Counterinsurgent Force} Posture, Sanctuary, and External Support

Most social scientific explanations of conflict outcome make a strong and ultimately problematic assumption about the behaviour and disposition of the local population. Each assumes that the population is generally supportive of the insurgency, likely providing the rebellion with material resources and refusing to denounce insurgents to state forces. This assumption, which is common across all but one of the explanations surveyed below, is problematic because there is actually considerable variation in the level of support that the population of a contested area provides to an insurgency.

The MNLF insurgency in the Philippines, for example, obtained a significant level of popular support, as did the GAM insurgency in Aceh, the Mujahideen insurgency in Afghanistan, the LTTE in Sri Lanka, the CCP in China, the FMLN in El Salvador, and the Vietcong in Vietnam. Other insurgent groups, such as the RUF in Sierra Leone, the Montoneros in Argentina, and the Tupamaros in Uruguay, the FARC in later years in Colombia, the Taliban in post-Soviet Afghanistan, and the Shining Path in Peru, obtained far less popular support. ${ }^{11}$ Since popular support for an insurgency varies radically across

\footnotetext{
${ }^{11}$ The estimates for popular support for each of these groups are from Ben Connable and Martin Libicki's dataset, How Insurgencies End. In their study, the popular support level for the group was determined as "whether the group was popular (in the sense of whether they could have won an election) in the region
} 
time and across cases, it is problematic to assume that it is fixed at a given level, as the theories reviewed below tend to do.

Below, I review explanations that emphasize strategic interaction between the insurgency and the counterinsurgency, counterinsurgent force posture, sanctuary for insurgent group, and external support for an insurgency as crucial covariates of successful insurgency. An account of conflict outcome can only be obtained if these factors, and many others, are wedded, at their core, to some understanding of how much popular support an insurgent group obtains.

\subsubsection{1 - Strategic Interaction}

Ivan Arreguin-Toft, building on the work of Andrew Mack, argues that the weaker side in an asymmetric conflict wins or loses depending upon the interaction of the strategy it adopts and the strategy of the stronger party. ${ }^{12}$ Arreguin-Toft classifies all strategies that either side can use into two ideal types: direct and indirect. Direct strategies, he argues, include conventional attack and conventional defence. The purpose of these strategies is to destroy the opponent's armed forces. Indirect strategies, which include guerrilla warfare and barbarism, target the opponent's will to resist by targeting a side's support base, although indirect strategies still require conflict between the two sides. ArreguinToft argues that when the strategies employed by the two parties are the same (direct and direct or indirect and indirect), the stronger party should win because "there is nothing to

for which it is fighting." This definition of popular support is similar to the one employed in this study, although the coding definition in Connable and Libicki's study is quite a bit narrower. See, Ben Connable and Martin Libicki, How Insurgencies End (Santa Monica: RAND Corporation, 2010), 204.

${ }^{12}$ Ivan Arreguin-Toft, How the Weak Win Wars: A Theory of Asymmetric Conflict (New York: Cambridge University Press, 2008); Andrew J.R. Mack, "Why Big Nations Lose Small Wars: The Politics of Asymmetric Conflict," World Politics, Vol. 27, no. 2 (1975), 175-200. For a more concise presentation of ArreguinToft's argument, see Ivan Arreguin-Toft, "How the Weak Win Wars: A Theory of Asymmetric Conflict," International Security, Vol. 26, no. 1 (2001), 93-128. 
mediate or deflect a strong actor's power advantage." ${ }^{13}$ When the strategies adopted by the combating parties are opposite (direct and indirect and indirect and direct), the weaker party should win most often because the mismatched strategies blunts the strong power's material advantage and result in a protracted struggle, which, as I outline below, theoretically favours the weaker party.

While the idea that symmetrical confrontation between a strong and a weak party should favour the powerful is fairly straightforward, the strategic interaction explanation falters somewhat in explaining weak party success. According to the theory, weak parties win when strategies are mismatched because the conflict becomes protracted. Insurgency is a fairly inexpensive form of warfare, while counterinsurgency involving modern armies is fairly expensive. ${ }^{14}$ Simply in terms of resource expenditure, the cheaper form of warfare should be more sustainable, everything else being equal. However, counterinsurgents usually have far larger budgets than insurgent groups and so could plausibly sustain a more expensive war effort for a longer period of time. Thus, when mismatched strategies result in a prolonged conflict, it is not altogether clear that the weaker party will necessarily be able to sustain its war-fighting efforts for a longer period of time than the stronger forces.

In fact, the conclusion that the weaker party should win protracted conflicts only holds if the weaker party in question has a sustained source of recruits and war-fighting capacity, which in the context of most insurgencies means the support of the

\footnotetext{
${ }^{13}$ Ibid., 34.

${ }^{14}$ David Galula, Counterinsurgency Warfare: Theory and Practice (Westport: Praeger Security International, 2006), 6-7.
} 
population. ${ }^{15}$ Even when the stronger power tries to directly destroy the weaker party and the weaker party adopts, say, a guerrilla warfare strategy that avoids direct confrontations, the stronger side can still do some damage to the weaker side (a point that I elaborate upon in chapter 4). The damage inflicted by the stronger party may be less than it could do if the strategies adopted by each side were matched, but the weaker party's resources are still going to be eroded under any combination of strategic choices. Spread over time, even a small amount of damage can add up to a big problem for a weaker combatant, unless they are able to replace their lost capacity faster than it is expended. ${ }^{16}$

Arreguin-Toft's strategic interaction explanation of why insurgents win, therefore, assumes that the population of a country is willing to supply the insurgency with recruits, military materiel, and other supplies so that the weaker party can last out, continue to wage a prolonged conflict, and press towards victory. The problem with this assumption is that there is actually considerable variation in the level of support that a population provides to an insurgent group. Since the level of support that an insurgent group obtains from the population is highly variable and since a certain level of popular support is needed in order for a weak party to sustain a protracted war effort, the strategic interaction explanation makes the problematic assumption that the people support the insurgency. If the population does not support the insurgency, then even mismatched strategies are unlikely to be enough to have the weak beat the strong.

\footnotetext{
${ }^{15}$ Certainly, as I point out in more detail below, insurgents can also get support from external sources. See Jeffrey Record, Beating Goliath: Why Insurgencies Win (Washington: Potomac Books, Inc., 2009); Nathan Leites and Charles Wolf, Jr., Rebellion and Authority: An Analytic Essay on Insurgency Conflict (Santa Monica: RAND Corporation, 1970).

${ }^{16}$ Nathan Leites and Charles Wolf, Jr., Rebellion and Authority: An Analytic Essay on Insurgency Conflict (Santa Monica: RAND Corporation, 1970).
} 


\subsubsection{2 - Counterinsurgent Force Posture}

Another explanation of why some insurgent groups win and others lose is proposed by Jason Lyall and Isaiah Wilson III. ${ }^{17}$ The authors argue that counterinsurgents have lost an increasing large percentage of the conflicts that they have engaged in because of the mechanization of modern militaries. In previous historical periods, state militaries lacked a long logistical tail, which devolved the supply of armies into the field and necessitated the practice of "foraging" for supplies. Since soldiers had to get supplies from the local area, they would invariably need to interact with the local people. Through this interaction, nominally aimed at obtaining material supplies for the army, state forces ended up obtaining a familiarity of the area and oftentimes information about the insurgency. This familiarity and information, in turn, assisted the typically better armed state forces in their efforts to find and destroy insurgents.

With the increasing mechanization of state armed forces, this link between the soldiers of the state and the population was severed, since modern armies now rely upon a long logical tail. Without frequent interaction with the local population, the counterinsurgency becomes subject to "information starvation." ${ }^{18}$ Lacking information on the insurgency, the counterinsurgency has a hard time identifying actual insurgents amongst the mass of the population. Efforts to use force against the insurgency in this context of poor information can often do more harm than good, leading to indiscriminate

\footnotetext{
${ }^{17}$ Jason Lyall and Isaiah Wilson III, "Rage Against the Machines: Explaining Outcomes in Counterinsurgency Warfare," International Organization, Vol. 63, no. 1 (2009), 67-106.

${ }^{18} \mathrm{Ibid} ., 68$. This idea is based upon Stathis Kalyvas' notion of the "identification problem." See, Stathis N. Kalyvas, The Logic of Violence in Civil War (New York: Cambridge University Press, 2009), 89-91.
} 
violence against the local population that creates a grievance that the insurgency can exploit to aid its efforts at mobilization. ${ }^{19}$

Similar to the strategic interaction explanation of conflict outcome, Lyall and Wilson III's account of why some insurgent groups win and others lose assumes the local population is generally supportive of the insurgency. In this case, the support provided by the people is largely passive. People refuse to provide information to the counterinsurgency on the location and membership of the insurgency, and, in so doing, support the insurgency. Since the people do not denounce the insurgency, the counterinsurgency is starved for information and becomes less effective. Certainly, the opportunity for the people to denounce the insurgency to the counterinsurgency could be lessened if there are lower levels of interaction between regime forces and the people, which is what high levels of armed forces mechanization might suggest.

There are several reasons to suspect, however, that the mechanization of a state's armed forces is not, in and of itself, the real driver of the population's willingness to passively support the insurgency by refusing to provide information to the counterinsurgency. First, there is no reason to necessarily expect that highly mechanized armed forces might not use their personnel in such a way as to result in frequent interaction with the population. Frequently, for example, state forces do make an active effort at patrolling neighbourhoods. Counterinsurgents also establish tip-lines and provide other ways that the people can access state forces. ${ }^{20}$ The population, for its part, might also detest the insurgency and make an active effort to inform on insurgents.

\footnotetext{
${ }^{19}$ US Army and Marine Corps Field Manual, FM 3-24, Counterinsurgency (Chicago: University of Chicago Press, 2007), 41.

${ }^{20}$ For a interesting firsthand account of this sort of process, see David Galula, Pacification in Algeria, 19561958 (Santa Monica: RAND Corporation, 2006).
} 
Additionally, Stathis Kalyvas has found that the population's willingness to denounce insurgents is a function of the level of control that the counterinsurgency can exert in an area. ${ }^{21}$ Higher levels of counterinsurgent control result in higher levels of denunciation, which provides the counterinsurgency with valuable information on the insurgency. Higher levels of insurgent control, in contrast, results in less denunciation to state forces and so less information. Again, there is no reason why a large quantity of highly mechanized soldiers cannot control an area just as well as the same quantity of less mechanized soldiers, provided the soldiers are used effectively for that purpose. If anything, the mobility advantages that come with helicopters, light armoured vehicles and the like suggests that, controlling for the total number of soldiers, highly mechanized forces should be able to exert control over a larger area than a less mechanized army. The presence of mechanized forces is insufficient to cause the population to passively support the insurgency by refusing to provide information to the counterinsurgency. The real fulcrum of success and failure in the mechanization account is the population's decision to either passively support the rebellion or denounce the insurgency to state forces. A given level of passive support is simply presumed to be present in each observation in Lyall and Wilson III's explanation. The force posture of a counterinsurgency is, again, an important factor in determining conflict outcome. However, as before, the level of passive support that the people provide to the insurgency varies significantly and cannot simply be assumed. Instead, it should be incorporated directly into the account of why some groups win and others lose.

${ }^{21}$ Stathis N. Kalyvas, The Logic of Violence in Civil Wars (New York: Cambridge University press, 2009). 


\subsubsection{3 - Sanctuary for a Rebel Group}

A third explanation for rebel group success and failure involves the presence or absence, respectively, of sanctuary for an insurgency in a state neighbouring a conflict area.

Sanctuary in neighbouring states provides a safe haven for insurgents. Whereas states are often constrained by the juridical limits of national boundaries, many rebel groups are not. By hiding in neighbouring states that are either supportive or unable to contend with an insurgency, a rebel group enjoys more safety than would likely be the case if the base area were established within the geographical boundaries of the state that is being challenged. ${ }^{22}$ An insurgent group is given the leisure to plan, organize, mobilize resources, and recoup from counterinsurgent offensives in this relatively safe sanctuary. Each of these features alone, and together in combination, presumably increases the odds that an insurgent group can be successful. Idean Salehyan, for example, finds that external sanctuary can provide both a safe haven for counterinsurgent military activity and a mobilization advantage to insurgents. ${ }^{23}$ Plausibly, larger insurgencies that are able to mobilize resources in relative freedom from the repressive activity of the state that they are challenging should be more likely to win, all things being equal. Indeed, in a study of the Portuguese wars in Angola, Guinea-Bissau, and Mozambique, Jeffrey Treistman finds

\footnotetext{
${ }^{22}$ An exception to this view is posited by Abdulkahar Sinno, who proposes that a safe haven within a country is crucial for effective organization and successful insurgency. See, Abdulkader H. Sinno, Organizations at War: In Afghanistan and Beyond (Ithaca: Cornell University Press, 2008).

${ }^{23}$ Idean Salehyan, "Transnational Rebels: Neighboring States as Sanctuary for Rebel Groups," World Politics, Vol. 59, no. 2 (January 2007), 217-242.
} 
that an external sanctuary that affords insurgents with a safe location for training, recruitment, and planning contributes to successful insurgency. ${ }^{24}$

As with the other explanations of successful and unsuccessful insurgency, the idea that the presence of external sanctuary causes a rebel group to be successful makes a large assumption about the behaviour of the local population within the country in conflict. Sanctuary for a rebellion, in this case, is only likely to contribute to successful insurgency when the population of the state that is being challenged supports, both actively and passively, the rebel group. The level of popular support that an insurgency receives conditions the effectiveness of an available sanctuary for two reasons. First, as Eqbal Ahmad puts it:

The incumbent army's pressure for conventional attack on an external sanctuary is yet another sign that a revolutionary war has been lost on home grounds. ... Politically and militarily, revolutionary guerrillas are by and large a self-sustaining group that can go on fighting indefinitely even if infiltration from across the border stops. ${ }^{25}$

Ahmad's comments highlight the idea that sanctuary is only likely to make a lasting positive contribution to rebel group success when the population supports the insurgency, that is, when the counterinsurgent's "war has been lost on home ground." Indeed, his notion that a revolutionary force is largely "self-sustaining" illustrates the idea that guerrillas tend to survive by being able to extract resources from the population to sustain their war efforts and that no amount of sanctuary can really compensate for a basic lack of popular support. While this sentiment overstates the affect of popular support on the

\footnotetext{
${ }^{24}$ Treistman also notes that sanctuary needs to be paired with rebel group ideological unity and common goals in order for the chances of success to improve. See, Jeffrey Treistman, "Home Away From Home: Dynamics of Counterinsurgency Warfare," Comparative Strategy, Vol. 31, no. 3 (2012), 235-252. ${ }^{25}$ Eqbal Ahmad, "Revolutionary Warfare and Counterinsurgency," in Gerard Chaliand ed., Guerrilla Strategies: An Historical Anthology from the Long March to Afghanistan (Berkeley: University of California Press, 1982), 253. Emphasis added.
} 
survivability of insurgency (as I will show throughout this work), it does highlight that sanctuary alone is insufficient to produce a successful rebellion. Popular support for the insurgency is needed too.

Secondly, while sanctuary is always an asset that protects an insurgency from counterinsurgent military activity, the effectiveness of any effort by an insurgent group to transgress borders and enter into a country to challenge the government is going to be conditioned by the disposition of the local population. If the population is overtly hostile to the insurgency, then efforts to enter into the country could well be met by local resistance or the systematic denunciation of insurgents to counterinsurgent forces. This process is illustrated in David Kilcullen's firsthand experience in Iraq during the recent insurgency, where the local population rejected the external involvement of al-Qaeda militants and rebelled against them. ${ }^{26}$ Certainly, an insurgency could coerce some level of acquiescence to their presence from the local people, but this is both a waste of finite resources, and, at least when coercion is used indiscriminately, likely to alienate the people from the insurgents and their cause. In other words, sanctuary in a neighbouring state is only an effective base area for insurgency when the population of the country in conflict supports the insurgency.

Overall, sanctuary alone is likely to be inadequate to ensure that an insurgency is successful. Popular support for the rebel group is, at least in the two basic ways mentioned above, even more important. Currently, the explanation for rebel group success that emphasizes the presence or absence of a sanctuary for an insurgency makes a strong assumption about the likely behaviour of the population of a contested country

\footnotetext{
${ }^{26}$ David Kilcullen, The Accidental Guerrilla: Fighting Small Wars in the Midst of Big Ones (New York: Oxford University Press, 2009), 158-159.
} 
(that is, that they generally support the insurgency). As with the other explanations for rebel group success and failure, simply assuming that the population is generally supportive of an insurgency overlooks the large amount of variation in levels of support and provides, at best, only a slim and partial picture of the drivers of conflict outcome.

\subsubsection{4 - External Support for an Insurgency}

A final explanation for rebel group success and failure found in the existing literature is that external support for an insurgency - particularly material support - drives successful conflict outcome. ${ }^{27}$ External support operates by increasing the strength of the insurgency relative to the regime. More external support leads to a stronger insurgent organization. As an insurgent group's material capabilities grow, it can stand against regime forces with greater ease and its chances of winning improve. The vast quantity of external support provided to the Vietcong and the Mujahideen in their successful wars with the world's two superpowers suggests that external support does indeed matter a great deal for effective insurgency. As Bard O'Neill puts it, "Unless governments are utterly incompetent, devoid of political will, and lacking resources, insurgent organizations normally must obtain outside assistance if they are to succeed."${ }^{28}$

External support is, indeed, very important for effective insurgency. Unlike the other explanations of rebel group success and failure, where popular support was a necessary compliment to the various causes of success, external support and popular

\footnotetext{
${ }^{27}$ For the main treatment expounding this idea, see Jeffrey Record, Beating Goliath: Why Insurgencies Win (Washington: Potomac Books, Inc., 2009). For a review of external support for insurgent groups, see Daniel Byman, Peter Chalk, Bruce Hoffman, William Rosenau, and David Brannan, Trends in Outside Support for Insurgent Movements (Santa Monica: RAND Corporation Publishing, 2001). ${ }^{28}$ Bard O'Neill, Insurgency and Terrorism: Insider Modern Revolutionary Warfare (Dulles: Brassey's, Inc., 1990), 111.
} 
support are largely supplementary. To some degree, having high levels of popular support makes up for not having that much external support, as in the case of the EPLF in Eritrea. By the same token, having high levels of external support can compensate for either a lack of popular support or a fairly small popular support base, as in the case of the LTTE in Sri Lanka. The sum of a group's total popular support and total external support determines the group's total capacity, assuming for the moment that both types of support manifest only as material capabilities. ${ }^{29}$

Since the two forms of support for an insurgent group are supplementary (a point that I explore in more detail in chapter 2), the external support explanation of rebel group success and failure makes far fewer assumptions about the disposition and behaviour of the local population. An insurgent group that has both popular support and external support would likely be doubly troubling for a regime. But, a rebellion with a high level of one or the other could well still pose a challenge to the state.

Yet, to form an accurate assessment of how well an insurgency is likely to do, it is necessary to know both the level of external support and the level of popular support. Since both forms of support - at least in their material form - are supplements for each other, knowing only one level or the other provides only a partial picture of a rebel group's true level of capacity. Such a partial picture lacks accuracy in its predictions of conflict outcome. Focusing only on external support, without an explicit consideration of how such support relates to the level of popular support that an insurgency receives,

\footnotetext{
${ }^{29}$ Several works note that external support can also be moral, ideological, and non-material. However, material support is by far the most important in determining conflict outcome. On the alternative forms of external support, see Bard O'Neill, Insurgency and Terrorism: Insider Modern Revolutionary Warfare (Dulles: Brassey's, Inc., 1990), 111-124; David Galula, Counterinsurgency Warfare: Theory and Practice (New York: Praeger Security International, 2006), 25-28. On the idea that an insurgent group gains material capacity from internal and external sources, see Nathan Leites and Charles Wolf, Jr., Rebellion and Authority: An Analytic Essay on Insurgency Conflict (Santa Monica: RAND Corporation, 1970).
} 
provides a valid but imprecise answer to the question of why some rebel groups win but others lose. A better theory would be able to account for both forms of support simultaneously.

\subsection{2 - The Illuminating Practical Work on Waging Insurgency}

The literature written by key practitioners of insurgency is quite clear: popular support matters for successful insurgency. Insurgent groups that lack popular support tend to fair poorly. Rebel groups that obtain the support of the population tend to do fairly well. Practitioners of counterinsurgency, for their part, also commonly assert that, in order to win, the state needs to break the connection between the insurgency and the population. ${ }^{30}$ The practical literature does well to emphasize the importance of popular support for successful insurgency (and the co-variation of a lack of support with unsuccessful rebellion). In this literature, the conceptualization of popular support that is adopted invariably amalgamates two analytically distinct things: 1) having more popular support and its affect on conflict outcome and 2) the actual process of mobilizing more popular support. I argue that, as a product of this amalgamation, the practical literature fails to consider how everything that a rebel group has to do in order to mobilize popular support might have additional effects on conflict outcome over-and-above producing a higher level of support amongst the people. Put another way, it is possible that having popular support is good for an insurgency, but undertaking certain actions in order to mobilize such support can cause an insurgency to lose the conflict.

\footnotetext{
${ }^{30}$ On this point, see Roger Trinquier, Modern Warfare: A French View of Counterinsurgency (Westport: Praeger Security International, 2006); David Galula, Counterinsurgency Warfare: Theory and Practice (Westport: Praeger Security International, 2006); David Kilcullen, Counterinsurgency (New York: Oxford University Press, 2010); US Army and Marine Corps Field Manual, FM 3-24, Counterinsurgency (Chicago: University of Chicago Press, 2007).
} 


\subsubsection{Mao, Che, and Giap: Practitioners of Insurgency}

The written works of Mao Tse-tung, Ernesto "Che" Guevara, and Vo Nguyen Giap stand as foremost examples of how practitioners of insurgency - some obviously more successful than others - understood the key role that the population plays in revolutionary warfare. A smattering of quotations highlights the central role of the people, which is clearly put forward as the key driver of successful insurgency.

Mao, in his numerous writings on guerrilla warfare, routinely emphasizes the central role that popular support plays in sustaining an insurgency and in pressing an insurgency towards victory against a regime. "Without a political goal," Mao writes, "guerrilla warfare must fail, as it must if its political objectives do not coincide with the aspirations of the people and their sympathy, cooperation, and assistance cannot be gained." ${ }^{31}$ Mao makes a similar point in his lectures on Protracted War. Here, Mao argues:

The mobilization of the common people throughout the country will create a vast sea in which to drown the enemy, create the conditions that will make up for our inferiority in arms and other things, and create the prerequisites for overcoming every difficulty in the war. To win victory, we must preserver in the War of Resistance, in the united front and in the protracted war. But all these are inseparable from the mobilization of the common people. $^{32}$

Indeed, Mao classically compares the insurgency to a fish and the population to the water surrounding, nurturing, and protecting it. "Many people think it impossible," Mao writes in On Guerrilla Warfare, "for guerrillas to exist for long in the enemy's rear [area]. Such a belief reveals lack of comprehension of the relationship that should exist between the people and the troops. The former may be likened to water and the latter to the fish who

\footnotetext{
${ }^{31}$ Mao Tse-tung, On Guerrilla Warfare, Samuel B. Griffith trans., (Mineola: Dover Publications, 2005$), 43$.

${ }^{32}$ Mao Tse-tung, On Protracted War (Honolulu: University of the Pacific Press, 2001), 60. Emphasis added.
} 
inhabit it. ... It is only undisciplined troops who make the people their enemies and who, like the fish out of its native element, cannot live." ${ }^{33}$

Mao is not alone in his emphatic emphasis on the importance of popular support to effective insurgency. Ernesto "Che" Guevara makes similar points. In his manual, Guerrilla Warfare, Che posits that, "guerrilla warfare is a war of the masses, a war of the people. The guerrilla band is an armed nucleus, the fighting vanguard of the people. It draws its great force from the mass of the people themselves." ${ }^{34}$ Likewise, in order to maintain a heavy tempo of guerrilla action against counterinsurgent forces, Guevara claims that "the absolute cooperation of the people ... is necessary." ${ }^{35}$ In similar form, General Vo Nguyen Giap, speaking of the Vietnamese war against the French, argues: "'The Vietnamese people won because their war of liberation was a people's war.' When the Resistance War spread to the whole country, the Indochinese Communist Party emphasized in its instructions that our Resistance War must be the work of the entire people. Therein lies the key to victory." ${ }^{36}$

Each of these theorists emphasizes different means that can be used to actually mobilize support. Of the three, Mao's thinking probably best exemplifies the problem with failing to distinguish between popular support as such and the requirements of the process of mobilization, largely because Mao gave the greatest attention to issues of mobilization. Mao - like Giap in many cases - highlights the importance of land redistribution from rich peasants to poor landless farmers. He also emphasizes political

\footnotetext{
${ }^{33}$ Mao Tse-tung, On Guerrilla Warfare, Samuel B. Griffith trans., (Mineola: Dover Publications, 2005), 9293.

${ }^{34}$ Ernesto Che Guevara, Guerrilla Warfare (Lincoln: Bison Books, 1998), 9-10.

${ }^{35}$ Ibid., 16.

${ }^{36}$ Vo Nguyen Gaip, People's War, People's Army: The Viet Cong Insurrection Manual for Underdeveloped Countries (New York: Bantam Books, 1962), 38-39.
} 
indoctrination, the protection of the people from bandits, and, crucially, the maintenance of good relations between the army and the people as means that could be used to mobilize the population. ${ }^{37}$

To effectively use these means of mobilization, Mao argues that there were certain organizational requirements that an insurgency needs to put into place. For example, Mao notes that, "If we lack national organization, we will lack the essential unity that should exist between the soldiers and the people." ${ }^{38}$ Likewise, discipline needs to be enforced amongst the insurgent guerrillas to ensure that they obeyed the so-called "three rules and eight remarks." ${ }^{39}$ Mao's emphasis on strong organization suggests that effectively using the means of mobilization requires a centralized organizational structure that can control its membership, coordinate the actions of the various parts of the insurgency, and that is generally guided by a coherent central leadership cadre. But herein lies the rub, as research on insurgent military performance and civil war has increasing found that how an insurgency organizes affects everything from its structural integrity, ${ }^{40}$ its susceptibility to leadership decapitation, ${ }^{41}$ the group's military effectiveness, ${ }^{42}$ and the insurgency's ability to undertake a variety of wartime tasks,

\footnotetext{
${ }^{37}$ On the Vietnamese methods of mobilization involving land reform, see Samuel L. Popkin, The Rational Peasant: The Political Economy of Rural Society in Vietnam (Berkeley: University of California Press, 1979); Jeffrey Race, War Comes to Long An: Revolutionary Conflict in a Vietnamese Province (Berkeley: University of California Press, 2010). On the protection of the people from bandits and the correction of land imbalances in China, see Odoric Y.K. Wou, Mobilizing the Masses: Building Revolution in Henan (Stanford: Stanford University Press, 1994).

${ }^{38}$ Mao Tse-tung, On Guerrilla Warfare, Samuel B. Griffith trans., (Mineola: Dover Publications, 2005$), 89$.

${ }^{39}$ Ibid., 92.

${ }^{40}$ Paul D. Kenny, "Structural Integrity and Cohesion in Insurgent Organizations: Evidence from Protracted Conflicts in Ireland and Burma," International Studies Review, Vol. 12, no. 4 (2010), 533-555.

${ }^{41}$ Jenna Jordan, "When Heads Roll: Assessing the Effectiveness of Leadership Decapitation," Security Studies, Vol. 18, no. 4 (2009), 719-755.

42 Patrick Johnston, "The Geography of Insurgent Organizations and its Consequences for Civil War: Evidence from Liberia and Sierra Leone," Security Studies, Vol. 17, no. 1 (2008), 107-137.
} 
including mobilization and the disciplining of the group's membership. ${ }^{43}$ In other words, how an insurgency organizes likely affects its ability to use the means necessary to mobilize popular support, but it is also plausible that how a rebel group organizes can have some additional effects upon how a conflict unfolds and, ultimately, on conflict outcome.

\section{Figure 1.2 - A Possible Causal Relationship Between Mobilization, Popular Support, and Conflict Outcome}

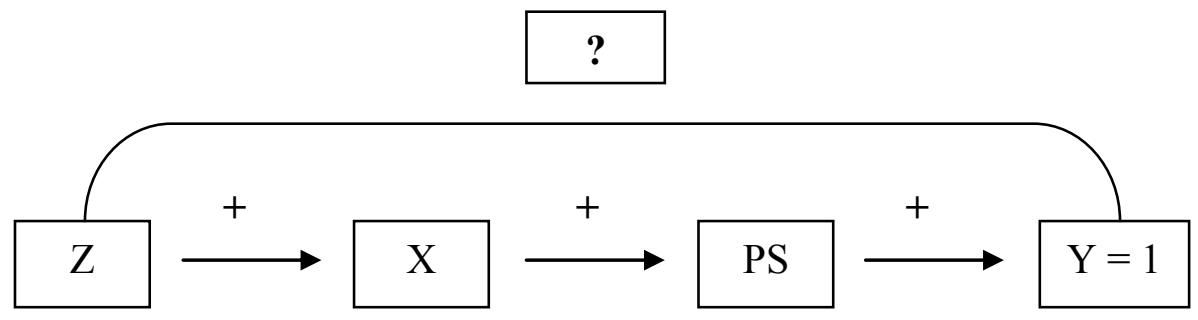

Figure 1.2 formalizes this critique using a simplified causal diagram. ${ }^{44}$ Here, $\mathrm{Y}$ is the dependent variable of conflict outcome, framed as a dichotomous variable. When Y equals 1 , an insurgency wins. When Y equals 0 , the state wins. Popular support for an insurgency is captured by the variable PS. It has a direct effect upon conflict outcome, Y. The effect, building upon the preceding literature review, is positive - hence, the plus sign above the causal arrow that leads from PS to $\mathrm{Y}=1$. More popular support for an insurgency increases the chances that the rebel group will win. The variable $\mathrm{X}$ is the means through which an insurgency mobilizes popular support. The means of mobilization, X, are positively related to a rebel group's realized level of popular support, PS. Different theories posit different means that can be used to mobilize popular support.

\footnotetext{
${ }^{43}$ Abdulkader H. Sinno, Organizations at War: In Afghanistan and Beyond (Ithaca: Cornell University Press, 2008).

${ }^{44}$ John Gerring, Social Science Methodology: A Unified Framework (New York: Cambridge University Press, 2012), 228-230.
} 
I develop an original exchange theory of mobilization in chapter 2 that synthesizes theory and historical evidence to pinpoint the general sort of means that all rebel groups use to mobilize the population under different circumstances. The variable $\mathrm{Z}$ represents how a rebel group organizes. How an insurgency organizes, Z, is positively related to its ability to use the means of mobilization, as denoted by the + sign above the causal arrow running from $\mathrm{Z}$ to $\mathrm{X}$. As the proceeding discussion made clear, how a rebel group organizes also likely has an effect on conflict outcome that occurs independently of its effect on an insurgency's ability to mobilize more popular support, which is signified by the long causal arrow running directly from $\mathrm{Z}$ to $\mathrm{Y}=1$. The direction of this effect is unclear, hence the ? mark about the causal arrow. At this stage, it is plausible that organization could either positively or negatively affect conflict outcome through this additional causal pathway.

A few things are left unresolved by this discussion. First, the means of mobilization, while impressionistically referenced in the work of Mao and others, are not well specified, which begs the question of how insurgent groups mobilize support. Second, it is not clear what sort of organizational structure actually results in the more effective use of the means of mobilization - therefore resulting in higher levels of popular support. Third, given an organizational structure that allows an insurgent group to effectively use the means of mobilization, it is not clear what the sign (positive or negative) and shape (linear, logarithmic, quadratic) of the relationship between that effective form of organization and conflict outcome might be.

\subsection{3 - Conclusions on the Social Scientific Explanations and the Thoughts of Practitioners}


In this section, I first reviewed some of the best explanations for why some rebel groups win and others lose. I focused on studies that pinpoint key covariates of insurgent group success and failure. The strategic interaction explanation, the mechanization and information starvation explanation, and the sanctuary explanation all assume that the population of the country in conflict is generally supportive of the insurgency. This assumption is problematic because, first, the amount of popular support that the people provide to an insurgent group is highly variable, and, second, because the operation of the proposed mechanisms actually requires that the people be fairly supportive of the insurgency. The external support argument, when the focus is placed solely on how much external support a group receives, overlooks the fact that popular support and external support are largely substitutes. Knowing how much external support a rebel group receives is, therefore, only going to provide a partial picture of how strong a rebel group is, which reduces the precision with which the explanation can account for variation in conflict outcome.

To reiterate again, my review of these explanations is not meant to deride these accounts of conflict outcome or to suggest that strategy, counterinsurgent force posture, sanctuary for insurgents, or external support for a rebellion do not matter. The review is meant to highlight that any explanation of why some rebels win and others lose is incomplete if it fails to explicitly incorporate the level of popular support that an insurgent group receives. Simply assuming that the population is generally supportive of a rebellion is insufficient.

Practitioners of insurgency clearly recognize that popular support for a rebellion is of crucial importance for an insurgency. However, I argued that while it is proper for 
these theories to emphasize the role that popular support plays in determining conflict outcome, the practical work tends to amalgamate an insurgent group's possession of popular support and the efforts that it needs to undertake in order to mobilize that support in the first place. In particular, the means of mobilization and the organizational structure that best allows a rebel group to use those means are not clearly specified. Additionally, any effects that a particular organizational structure might have on conflict outcome, independent of that particular structure's affect on mobilizing popular support, is not really considered at all.

\subsection{4 - Rebel Organization and Group effectiveness}

While the works explaining conflict outcome are problematic because they make untenable assumptions about the behaviour of the population and the role that rebel group structure plays in both the mobilization process and in determining conflict outcome, there are a few recent works that focus in on how a group structures itself and what effect these choices have on various aspects of a group's behaviour and performance. Core among these works are Paul Staniland's Networks of Rebellion, Jacob Shaprio's The Terrorist's Dilemma, and Jeremy Weinstein's Inside Rebellion. Given the similarity in the focus of these works and the arguments that I develop in my dissertation, I briefly discuss each in turn.

Stanliand's book advances the idea that how an insurgent group incorporates preexisting networks (both vertical networks and horizontal ones) affects the ability of the group to remain cohesive and act as a coherent organizational unit. While Staniland notes that more coherently formed groups (such as integrated groups in his typology) tend to be more militarily effective, his main purpose is to investigate the origins of insurgent 
organizations and explain variation in group structure over time and across groups. ${ }^{45}$ Staniland certainly emphasizes that insurgent group form affects various outcomes, but notes that "a particular organizational structure does not necessarily lead to a specific political or military overall outcome. ${ }^{46}$ In this sense, Staniland's work overlaps with the work done in chapters 2, 3 and 4 of my dissertation, where I answer questions about why groups structure themselves in a particular way, but does not extend to cover directly my overarching question of what causes rebel group success and failure.

In The Terrorist's Dilemma, Jacob Shaprio focuses his attention on how principal-agent problems create a dilemma for terrorist leadership. On the one hand, they can maximize their security by minimizing their level of bureaucratization. Minimal levels of bureaucratization, on the other hand, can severely reduce the efficiency with which a terrorist organization is able to undertake effective, well-timed and well-targeted attacks. Essentially, Shaprio argues that terrorist groups need to find ways to balance their operational efficiency with their prospects for organizational survival. Shaprio points to an important dilemma that terrorist groups face and he demonstrates that terrorist groups ranging from Russian Anarchists in the early 1900s to Al-Qaeda in Iraq face similar management dilemmas. ${ }^{47}$ Like with Stanliand, Shaprio stops short of actually using his framework to explain why differently organized groups are more or less likely to succeed, although the clear implication is that more bureaucratic groups that are more effective should be better at obtaining their political objectives than less bureaucratic groups (even if they are more likely to be targeted by state forces).

\footnotetext{
${ }^{45}$ Paul Staniland, Networks of Rebellion: Explaining Insurgent Cohesion and Collapse (Ithaca: Cornell University Press, 2014).

${ }^{46}$ Ibid., 8.

47 Jacob N. Shapiro, The Terrorist Dilemma: Managing Violent Covert Organizations (Princeton: Princeton University Press, 2013).
} 
In Inside Rebellion, Jeremy Weinstein argues that rebel group organizational structure is not, in fact, voluntarily chosen by an insurgency. Instead, it is a function of an insurgency's "resource endowment". ${ }^{48}$ The nature of a group's resource endowment (split between lootable sources and popular support) determines both the type of recruits a group is likely to attract and the form of organization the group is likely to develop. A lootable endowment attracts individuals that are out for their own short run interest. Such individuals make organizational control difficult, leading to decentralized organizational structures. As a result of its recruits' temperament and the group's structure, an insurgent group that is based around a lootable resource endowment tends to be more indiscriminately violent towards the populace. In contrast, a rebel group that is based upon an endowment of popular support tends to attract recruits that are concerned with the long term, which facilitates the development of a centralized organizational structure. In turn, such groups use less indiscriminate violence against the people. As with the other two works considered here, Weinstein does not extend his discussion to cover conflict outcome and focuses instead on the questions of why some groups structure themselves as they do and how this structure affects the group's use of violence.

In this section, I briefly discussed three works that overlap considerably with my own work's focus on how insurgent groups structure themselves to fulfil the tasks of insurgency. While developing slightly different answers to some questions of organization, my work primarily moves beyond these previous studies by explicitly connecting the previously disparate issues of mobilization, organization, and conflict outcome.

\footnotetext{
${ }^{48}$ Jeremy Weinstein, Inside Rebellion: The Politics of Insurgent Violence (New York: Cambridge University Press, 2009).
} 


\section{5 - A Note on Methods and Methodology}

My work is presented, and the research was conducted, in two parts. John Gerring calls these two parts the "discovery" and the "appraisal" stages. ${ }^{49}$ The first stage corresponds to the theory-building stage. The second stage involves the testing of the theory to see how well it fits with the available empirical evidence. After discussing the methodology underpinning the work in each of these sections, I specify some of the assumptions that underpin the mobilization and conflict outcome theory.

\subsection{1 - Part 1, The "Discovery Stage": Building a Theory of Mobilization and Conflict} Outcome

The first part of my dissertation builds a theory linking a rebel group's mobilization of popular support to conflict outcome. To develop the theory, I rely extensively on wideranging secondary historical material. The process of data collection and synthesis into theory is driven by a desire on my part to read as widely as possible. My motive in reading widely like this is rooted in my desire to build a general theory of insurgent conflict outcome. At various stages of the research, I also rely heavily on extant theory to guide my way.

I use a few methodological strategies in the construction of the theory. First, in developing the theory, I routinely consider what other things I should expect to see if the primary causal relationship is true. ${ }^{50}$ This method is commonly referred to as "causal-

\footnotetext{
${ }^{49}$ John Gerring, Social Science Methodology: A Unified Framework (New York: Cambridge University Press, 2012), 28.

${ }^{50}$ I first came across this notion in Gary King, Robert O. Keohane, and Sidney Verba, Designing Social Inquiry: Scientific Inference in Qualitative Research (Princeton: Princeton University Press, 1994), 30.
} 
process observation. ${ }^{51}$ Following this approach allows me to determine the internal validity of the theory more precisely by increasing the number of functional observations that I have at any given point and time by relying upon strictly non-comparable forms of data. ${ }^{52}$ For example, in chapter 2, I argue that the amount of popular support an insurgent group wants to mobilize is conditioned by the strength of the state. Stronger states should result in higher levels of demanded popular support by a rebel group, everything else being equal. The secondary implication of this hypothesis is that groups that base their mobilization on small segments of a population, say, a minority ethnic community or upon only a single economic class, should either lose due to a lack of support or be compelled to expand their mobilization base. I found support for both the primary prediction and the two secondary implications. Proceeding in this way helped me to fully specify the theory and increase its internal validity. Indeed, as Gerring puts it, "causalprocess observations play a ubiquitous role in causal inference. Arguably, they are more valuable than dataset observations because they pertain to different aspects of a causal relationship, providing a form of triangulation. ${ }^{153}$

Again to help clearly specify the theory, I frequently use diagrammatical representations of the causal relations that are at play. These diagrams are helpful for readers and have helped me crystallize my own thinking on a subject. By placing a causal relationship on an $\mathrm{X}, \mathrm{Y}$ (sometimes $\mathrm{X}, \mathrm{Y}, \mathrm{Z}$ ) graph, I find that I am forced to consider what is structuring the shape and direction of a relationship between $\mathrm{X}$ and $\mathrm{Y}$ and what causes both shifts and rotations in the associational trend line between the independent

\footnotetext{
${ }^{51}$ John Gerring, Social Science Methodology: A Unified Framework (New York: Cambridge University Press, 2012), 328-333.

52 John Gerring, Social Science Methodology: A Unified Framework (New York: Cambridge University Press, 2012), 328-333.

${ }^{53} \mathrm{Ibid}$., 333. Emphasis in the original.
} 
and dependent variables. To me, these are useful things to think about, as they are some of the necessary elements of a complete and internally consistent theory. The graphical figures, except where otherwise indicated, are heuristic representations of how I conceive of the direction and shape of the relationship between variables as it is suggested by the evidence and the theory. ${ }^{54}$

\subsection{2 - Part 2, The "Appraisal Stage": Testing the Theory against Empirical Evidence}

I conduct a series of tests to ascertain the validity of the theory, both internally and externally. In chapter 5, I run a series of descriptive statistical tests on some core implications of the mobilization and conflict outcome theory. The aim of these tests is to determine the validity of the core processes of the theory through a process of triangulation. The tests vary in terms of their "certainty" and "uniqueness", to use the language of Stephen Van Evera. ${ }^{55}$ Certainty involves predictions that must follow from the theory, but that follow from other theories as well. Uniqueness is the idea that a prediction might be unique to the proposed theory and not predicted by other theories. Some of the tests in chapter 5 combine both certainty and uniqueness to form "doublydecisive tests." ${ }^{56}$ Other tests conducted in chapter 5 are certain, but not unique, to the mobilization and conflict outcome theory. Together, this battery of tests shows that the theory is supported by some broad evidence, giving it some claim to generalizability.

\footnotetext{
${ }^{54} \mathrm{John}$ Gerring is referring to causal diagrams in general, but I think his insights here are applicable to diagrammatical representations of causal phenomenon. See, John Gerring, Social Science Methodology: A Unified Framework (New York: Cambridge University Press, 2012), 228.

${ }^{55}$ As Van Evera phrases it, "A certain prediction is an unequivocal forecast. ... A unique prediction is a forecast not made by other known theories." Stephen Van Evera, Guide to Methods for Students of Political Science (Ithaca: Cornell University Press, 1997), 31.

${ }^{56}$ Ibid., 32.
} 
In chapter 6, I also test the internal validity of the theory against evidence from four cases. These case studies provide some support for how well the proposed mechanisms operate. During the case studies, I use what Alexander George and Andrew Bennett call "process tracing," which is a method used to see if the historical evidence shows that a theory's proposed mechanisms are in fact in operation in a given case.$^{57}$ The evidence presented in chapter 6 shows that the mechanisms underlying the mobilization and conflict outcome theory are supported across four different cases. These finding show that the theory has a high level of internal validity. The comparative element of the cases also buttresses the theory's external validity to some degree.

\subsection{3 - Assumptions}

In order to construct a theory that is both parsimonious and powerful in terms of its explanatory ability, I made several general assumptions that need to be clearly acknowledged.

First, I assume that a rebel group faces an "average" state. By average, I mean a state that does not perform its counterinsurgency tasks with either exceptional acumen or large-scale ineptitude. Obviously, states that are very good at waging counterinsurgency would be more likely to win. States that are bad at defeating insurgencies would, well, have a hard time defeating an insurgency. My goal in developing my theory is to specify how a rebel group's actual mobilization of popular support relates to conflict outcome. The theory is probabilistic rather than deterministic, so the variables that I pinpoint increase the odds that one or the other side will win, but I do not argue that any of the

\footnotetext{
${ }^{57}$ Alexander L. George and Andrew Bennett, Case Studies and Theory Development in the Social Sciences (Cambridge: MIT University Press, 2005), 6-7.
} 
variables are necessarily sufficient to produce a positive or negative outcome. In this sense, a better-than-average state would have a higher probability of winning and worsethan-average state would be more likely to lose.

Secondly, I assume that a rebel group has already overcome the initial collective action problem and formed a revolutionary core with at least some endowment of resources. There is a large literature on solving the so-called collective action problem, as it was first developed by Mancur Olsen ${ }^{58}$ Rather than delving into this well-researched area, I focus in on how a group that has been established grows over time and particularly how achieving that growth relates to conflict outcome. Obviously, this research problem could also be considered one of extended collective action, but my point is that I am not concerned with where a rebel group comes from in the first place, although the models presented in chapter two do provide an explanation for this type of event. ${ }^{59}$

Third, particularly in my discussion in chapter 2 of how an insurgent group mobilizes popular support, I assume that the people cannot flee from the conflict zone and so opt-out of supporting the regime, supporting the insurgency, or trying to remain neutral. Internal and external population movement during civil war is certainly a largescale phenomenon and critiques can be levelled against theories that assume that the population is fixed in place. ${ }^{60}$ In this case, I maintain this assumption in the theoretical portion of my dissertation because it is not immediately apparent which people will move

\footnotetext{
${ }^{58}$ On the collective action problem, see Mancur Olsen, The Logic of Collective Action: Public Goods and the Theory of Groups (Cambridge: Harvard University Press, 1971). For an excellent treatment on the various ways in which a rebel group can overcome the collective action problem, see Mark Irving Lichbach, The Rebel's Dilemma (Ann Arbour: University of Michigan Press, 2009).

${ }^{59}$ For an interesting account of the problem of "fanatics and first actors", see Roger D. Peterson, Resistance and Rebellion: Lessons From Eastern Europe (Cambridge: Cambridge University Press, 2006), 272-295.

${ }^{60}$ Eric Jardine, "Population-Centric Counterinsurgency and the Movement of Peoples," Small Wars and Insurgencies, Vol. 23, no. 2 (2012), 264-294.
} 
first and under what conditions they will use flight as a strategy versus other practices such as acquiescence to rebel or state demands. I relax this assumption in the empirical portions and consider how population movement affects the ease with which an insurgency mobilizes support.

Fourth, in chapter 5, I derive a baseline statement on the relationship between rebel group mobilization and conflict outcome. To test this baseline, I assume that the rebel group exists in a condition of autarky, which can be defined a closed system that is totally reliant on its own resources. ${ }^{61}$ This assumption is useful in the initial testing of the mobilization and conflict outcome theory for two reasons. First, the presence of autarky means that an insurgent group is going to have to rely upon the mobilization of the population if it wants to secure enough capacity to effectively challenge the regime. This reliance means that the effects that the theory suggests should be present are likely going to be most pronounced under the condition of autarky. As this dissertation is partially a theory-building exercise, looking in the "most likely" places for evidence of the theory is a valuable initial step. ${ }^{62}$ Secondly, I use an insurgent group's relative share of the total number of mobilized soldiers in the area of conflict as a proxy for its level of mobilized popular support relative to the state. I use the rebel group's total number of soldiers as a measure of its absolute size. These measures are used to test two derivative hypotheses in chapter 5. If a rebel group has external support, its number of mobilized soldiers tends to get artificially inflated, either because it has soldiers from outside of the country or because it has externally derived weapons and armaments that mean it can equip more

\footnotetext{
${ }^{61}$ See, Michael Todaro and Stephen Smith, Economic Development, 10th ed., (Toronto: Pearson, Addison Wesley, 2009), 819.

${ }^{62}$ On "most likely" cases, see Alexander L. George and Andrew Bennett, Case Studies and Theory Development in the Social Sciences (Cambridge: MIT University Press, 2005), 121-122.
} 
soldiers. Either way, the presence of external support makes the measure of insurgent group relative (and absolute) capacity used for two of the tests in chapter 5 less accurate as a measure of the total amount of mobilized popular support. Absent a more refined measure of the actual amount of popular support that different rebel groups have mobilized, using the imperfect proxy under a strict assumption for a series of test is better than not doing any empirical tests at all. I would note, however, that I do not think that the assumption of autarky is essential for the operation of the theory, merely that the anticipated effects are likely to be most pronounced under this condition.

Finally, the mobilization and conflict outcome theory is concerned, at its core, with a rebel group's production of outputs that secure it higher levels of popular support, things such as services, payments, propaganda, and coercion. The last assumption that I maintain is that the production technology available to insurgencies is constant, both across groups and over time. This is a strong assumption, since, particularly when it comes to producing propaganda, modern social media, telecommunications, and so forth has undoubtedly reduced the cost of producing a propaganda message. Other changes have likely occurred as well. The effect of changing technology on the core processes discussed in this work is an interesting one to consider, but left to another time.

I also make several additional assumptions on a more selective basis. These additional assumptions are made for illustrative and analytical purposes. When an additional assumption is being made, I state so plainly in the text.

\section{6 - A Summary of The Mobilization and Conflict Outcome Theory and Chapter Outline}


Good theory is parsimonious, descriptively accurate, predicatively useful, falsifiable, logically consistent, and complete. ${ }^{63} \mathrm{~A}$ theory that purports to explain why some rebel groups win and others lose should be all of these things and account for the four trends pointed out above. In other words, a good theory of conflict outcome should also:

1) Be able to account for why rebel groups are winning more now than they did previously;

2) Be able to explain the drivers of the use of force within the conflict;

3) Be able to account for variation in the level of support that the population provides to the insurgency, in addition to the other relevant factors affecting conflict outcome;

4) Be able to account for how the requirements of mobilizing popular support might have an independent effect on conflict outcome.

In my dissertation, I develop what I have come to call the mobilization and conflict outcome theory to answer the overarching research question of why some rebel groups win and others lose.

In Chapter 2, I specify how rebel groups obtain popular support through an exchange relationship. In this process of exchange, an insurgent group provides remunerative compensation (services and goods) to the people in order to purchase their support. A rebel group can also use preference manipulation tactics (coercion and propaganda) to favourably affect the preferences of the population towards supporting the rebellion at a less cost to an insurgency. The state's behaviour and structure vis-a-vis the

\footnotetext{
${ }^{63}$ For a good discussion of developing policy-relevant theory, see Stephen M. Walt, "The Relationship between Theory and Policy in International Relations," Annual Review of Political Science, Vol. 8 (2005), 23-48. For a similar list of features of good theory, see John Gerring, Social Science Methodology: A Unified Framework (New York: Cambridge University Press, 2012), 58-73.
} 
people affects the population's underlying preference for an alternative to the current regime. When the regime is politically exclusive (as opposed to inclusive) and uses indiscriminate violence (as opposed to discriminate violence), the population's preferences towards the state sour and an insurgent group is able to mobilize more popular support at less cost to the rebellion. How much popular support an insurgent group requires in order to effectively challenge the state is conditioned by the strength of the state and the price and availability of substitutes to popular support, such as external support, illicit crops, or lootable natural resources.

The mobilization process, using the means of remunerative compensation and preference manipulation tactics, is inherently cumulative. A rebel group expends resources to produce the means that it uses to purchase popular support, which manifests as capacity augmenting inputs. In Chapter 3, I show why rebel groups need to be concerned with issues of scale and efficiency in their production of popular supportsecuring outputs. I detail two ways that an insurgent group can more easily obtain organizational growth over time. One method is for an insurgent group to increase the scale of its administrative presence, which can be done through some combination of original organization building and the incorporation of pre-existing socio-political networks. Building a larger scaled administrative presence allows an insurgency to produce more output. Higher production levels can generate economies of scale in the production of popular support-securing outputs and distribute all fixed costs across a large quantity of output. This process reduces an insurgency's long run average cost per unit of output produced. As a group's long run average costs decline, its profit margins improve and the odds that a group can grow in size over time increase. The other method 
is for an insurgent group to adopt a centralized organizational structure, with hierarchical decision-making, specialization of labour, coordination mechanisms, and control and monitoring systems to reduce principal-agent problems. As these sources of cost are corrected for, the efficiency of the group's production increases and its ability to mobilize more popular support over time grows.

The incentive to centralize its organizational structure and to expand its administrative presence increases as an insurgency grows in size. Organizational inefficiencies increase as a group's absolute size rises. Likewise, since the population has differential preferences towards supporting an insurgency, the cheapest supporters (those that have a strong preference for revolt) tend to support the insurgency early on, while the more expensive supporters (those that have a weaker preference for revolt) tend to only join at later stages of the conflict, particularly once the insurgency has reach a larger size. This association entails that an insurgency needs to produce even higher levels of popular support-securing outputs as it grows in order to just maintain a constant growth rate, which creates an incentive towards expanding the group's administrative presence.

These features of a rebel group's organizational structure and its administrative presence are beneficial when the focus is solely placed on the scale and efficiency of an insurgency's mobilization of popular support. When the focus is shifted to how an insurgent group interacts with the state that it is challenging, both of these productionenhancing characteristics have negative effects on an insurgency's chances of beating the state.

As I show in chapter 4, when an insurgent group increases its administrative presence and adopts a centralized organizational structure, it becomes both more 
vulnerable to targeting by state forces and less resilient to being targeted. All this suggests that a rebel group faces a core insurgent's dilemma in its efforts at mobilizing popular support. On the one hand, an insurgency that needs to grow in size in order to effectively challenge the state should adopt a centralized organizational structure and expand its administrative presence. On the other hand, an insurgency that needs to increase its resilience to state military activity and to reduce its vulnerability to being targeted by state forces should decentralize its organization and reduce the scale of its administrative presence.

In chapter 5, I further specify the core insurgent's dilemma by disaggregating the process of a conflict into cycles or periods, encompassing years, seasons, or some other temporal unit. In each conflict period, there is a chance that the state might win, that the insurgency might win, or that both sides might simply survive to continue fighting in the next period. A rebel group's odds of winning improve as it mobilizes more popular support. In this sense, having popular support is, as the literature reviewed above suggests, positively related to rebel group success. However, it is often the case that in order to actually mobilize more support over time, an insurgent group needs to adopt a centralized organizational structure and expand the scale of its administrative presence. Both of these features of a rebel group increase the odds that the state can effectively target and disrupt an insurgency with military force.

Whether or not an insurgent group is able to mobilize more popular support ("turn a profit," so to speak) over time depends upon what I call the rebel group's mobilization context: a constellation of factors that condition the population's willingness to supply a given bundle of popular support to an insurgency in exchange for a given 
bundle of popular support-securing outputs. The more favourable the rebel group's mobilization context, the easier it is for an insurgency to ensure organizational growth. Thus, the better the mobilization context, the weaker the incentive toward organizational and administrative reform. Conversely, the more unfavourable the mobilization context is, the harder it is for an insurgency to grow over time and the more important the efficiency enhancing characteristics of organizational centralization and a large-scale administrative presence become. In the end, an insurgency should be able to mobilize more support with less destructive features in a favourable context, and so should win more often, than a rebel group in a less favourable mobilization context.

In chapter 6, I generate a typological theory of rebel groups that classifies all insurgencies according to both the scale of their administrative presence and the degree of their organizational centralization. Based upon this categorization, I end up with four types of insurgent groups (diffuse, vanguard, fragmented and bureaucratic). I then specify how each conflict should unfolded based upon each type of insurgency's administrative and organizational characteristics. I test these predictions against four cases of insurgency: the Mau Mau in Kenya, the Shining Path in Peru, the Mujahideen in Afghanistan, and the EPLF in Eritrea.

Finally, in chapter 7, I conclude with some thoughts on the limitations of my research and avenues for further exploration. I also talk briefly about the potential policy implications of the mobilization and conflict outcome theory. 
Jardine, 55

\section{Chapter 2: Insurgency and Popular Support}

Popular support for an insurgency is a crucial factor in the production of a successful conflict outcome for a rebellion. Despite the importance of popular support for successful insurgency, several questions about the interrelationship between popular support and guerrilla movements are often not asked together or are left entirely unanswered:

1) What is popular support for an insurgency, how does it manifest, and why does it matter?

2) How much popular support does an insurgency need?

3) How do insurgent organizations obtain the support of the population?

4) What role does the state play in the relationship between the population and an insurgent group?

In this chapter, I answer these questions by drawing on broad comparative evidence from multiple insurgencies. I argue that popular support for an insurgency is a combination of active and passive actions on the part of the population in favour of a rebel group. I argue further that, related to the first point, popular support for a rebel group manifests as actions (or, at times, inaction) by the population that enhances the capacity of the insurgency to administer territory and make war against the state. Popular support matters for an insurgency because it increases the capacity of a rebellion relative to a regime and is, at times, the primary source of people and material for a rebellion. Additionally, I posit that an insurgent group needs enough popular support to effectively challenge the state both politically and militarily. The actual amount of popular support 
that an insurgent group needs, and consequently demands from the population, is conditioned by both the strength of the state and the 'price' of substitutes for popular support.

An insurgent group, I argue, obtains popular support through an exchange process. In this process, an insurgent group can increase the popular support that it receives in two non-exclusive ways. First, an insurgency can obtain popular support by compensating the population for their support through the provision of a bundle of services and goods. Second, an insurgency can put pressure on individual preferences, effectively altering the amount of payment that individuals within the population require in exchange for supplying a given level of popular support to the insurrection. Stated otherwise, an insurgency can either satisfy an individual's preference for compensation or manipulate those preferences in favour of the rebellion. The basic implication of this exchange relationship is that the more services and goods that an insurgency supplies to the people and the more an insurgent group manipulates individual preferences through coercion and propaganda, the more popular support (measured as capacity augmenting inputs) the insurgency receives. Finally, I argue that both the characteristics and the behaviour of the state affect the exchange relationship by influencing the willingness of the population to supply popular support to a rebel group at a given price.

Below, in the first section, I outline what popular support is and why it matters. In the second section, I pinpoint the conditions that determine how much popular support a rebel group needs. In the third section, I detail the various ways in which an insurgency can obtain popular support. In the fourth section, I elaborate upon the state's role in 
determining how much popular support a rebel group can obtain at any given point and time. Then, I offer conclusions.

\section{1 - Popular Support for an Insurgency: What is it, How does it Manifest, Why Does it Matter?}

In this section, I explain what popular support for an insurgency is, how it manifests, and why it matters. I argue that popular support is a fluid combination of active and passive actions and inactions undertaken by the population in favour of the insurgency. Such support manifests as war-fighting and administrative capacity for an insurgent group, with active support directly augmenting the strength of a rebellion and passive support increasing the relative capacity of an insurgency by diminishing the war-fighting capacity of the state. I posit that popular support for an insurgency matters because it is $a$ - if not the - primary source of insurgent capacity, particularly when external sources of material aid are not forthcoming.

Popular support for an insurgency, or, more properly, support provided by the population to an insurgent group, can be defined as either passive or active behaviour on the part of individuals within the population in favour of a rebel group. The distinction between passive and active support is fairly ubiquitous in the literature on insurgency and counterinsurgency. ${ }^{64}$ It is a useful distinction because it draws a clear line between the possible types of supportive behaviour that individuals can exhibit towards an insurgency. It is also analytically useful because it focuses on the behaviour of individuals rather than their hidden preferences. Focusing on the revealed preferences of the population, as shown by their actual behaviour, provides a clear act that can be

\footnotetext{
${ }^{64}$ Bard E. O'Neill, Insurgency and Terrorism: Inside Modern Revolutionary Warfare (Dulles: Brassey's, Inc., 1990), 70-74.
} 
observed and recorded. Moreover, with the focus placed on the actions of the population, the factors inducing or compelling people to behave in a particular way can be clearly specified.

Passive support for an insurgency is by far the most common form of support that the population can provide to a rebel group. ${ }^{65}$ Such support involves only favourable inaction on the part of the population towards the insurgency. Passive support manifests as loyalty to an insurgency. Loyalty towards the insurgency means, most simply, that a population that passively supports an insurrection will not disclose information on insurgent movements, intentions, and organization to the forces of the counterinsurgency. During the Huk rebellion in the Philippines, for instance, peasants that supported the insurgency often withheld information on guerrilla activity from the Japanese forces. As one peasant from San Ricardo noted, when Japanese patrols entered the villages, "we were in a difficult situation. We didn't like the Japanese, of course, but we couldn't stand up and fight either. So we were just pleasant, but never said anything about the Hukbalahap. Then they'd [the Japanese forces] leave." ${ }^{66}$ Similarly, the population of Mallawi in Upper Egypt often refused to cooperate with security forces looking for AlJamaa Al-Islamiyya insurgents. As one police officer noted, "People here are very negative. ... We wish they would tell us about the hideouts of the militants. ${ }^{67}$ In a similar fashion, during the FMLN insurgency in El Salvador, one resident of the area of Las

\footnotetext{
${ }^{65}$ The U.S. Army and Marine Corps, Counterinsurgency Field Manual, FM 3-24 (Chicago: University of Chicago Press, 2007), 35-36

${ }^{66}$ Cited in, Benedict J. Kerkvliet, The Huk Rebellion: A Study of Peasant Revolt in the Philippines (New York: Rowman \& Littlefield Publishers, Inc., 2002), 64.

${ }^{67}$ Cited in, Stefan Malthaner, Mobilizing the Faithful: Militant Islamist Groups and Their Constituencies (New York: Campus Verlag, 2011), 161.
} 
Marias indicated that, "We used to help them [the FMLN] by telling the military, 'No, haven't seen anyone'." 68

Passive support for a rebellion indirectly augments the war-fighting capacity of an insurgency relative to the state. When the population refuses to supply the forces of the state with key information on the location, disposition, and organization of an insurgent group and its membership, the overall effectiveness of counterinsurgent military actions is reduced. ${ }^{69}$ During the insurgency in Malaya, for example, one British officer recounted, "We could not bring our military machine to bear without information, and we could not get information without the support of the population." ${ }^{70}$ Likewise, in Peru in the 1980s, it was noted that "The police were unsuccessful in their efforts to identify or capture Sendero militants. Rather, many suspects were rounded up in hopes of capturing a few active guerrillas. A central problem was a lack of intelligence about guerrilla operations in rural areas, largely because the population neither trusted nor cooperated with the police." ${ }^{71}$ Similarly, the U.S. Army and Marine Corp Counterinsurgency Field Manual posits, "Without good intelligence, counterinsurgents are like blind boxers wasting energy flailing at unseen opponents and perhaps causing unintended harm." ${ }^{72}$

\footnotetext{
${ }^{68}$ Anonymous interview respondent, cited in, Elisabeth Jean Wood, Insurgent Collective Action and Civil War in El Salvador (New York: Cambridge University Press, 2003), 126.

${ }^{69}$ The U.S. Army and Marine Corps, Counterinsurgency Field Manual, FM 3-24 (Chicago: University of Chicago Press, 2007), 41; Stathis Kalyvas, The Logic of Violence in Civil War (New York: Cambridge University Press, 2009), 174-176.

${ }^{70}$ Oliver Crawford, The Door Marked Malaya, cited in, Stathis Kalyvas, The Logic of Violence in Civil War (New York: Cambridge University Press, 2009), 174.

${ }^{71}$ Ronald H. Berg, "Peasant Responses to Shining Path in Andahuaylas," in David Scott Palmer ed., Shining Path of Peru (New York: St. Martin's Press, 1992), 95.

${ }^{72}$ The U.S. Army and Marine Corps, Counterinsurgency Field Manual, FM 3-24 (Chicago: University of Chicago Press, 2007), 41.
} 
Active support involves the overt participation of the population in favour of an insurgency. It is, therefore, the far rarer form of popular support. ${ }^{73}$ Active support manifests in a variety and fluid combination of forms, including monetary support for a rebellion, the supply of material and human resources for use in insurrectionary activity, and the provision of food and shelter to guerrillas. The exact combination of support that is provided will vary across time, circumstance, and individuals, but the effect is fairly inelastic: more active popular support for a rebellion provides more capacity augmenting inputs for an insurgency, which can then be transformed into greater war-fighting and administrative outputs. ${ }^{74}$ During the Shining Path insurgency in Peru, for example, active supporters of Sendero Luminoso would "provide minor support in the form of money, medicine, clothes, food, arms, or explosives [to the insurgency]." ${ }^{75}$ Similarly, in Vietnam, a Vietminh guerrilla warfare manual clearly laid out the central role of active popular support in effective guerrilla warfare:

The population ... supplies liaison agents, hides and protects us, assists our actions near posts, feeds us and looks after our wounded. ... Cooperating with guerrillas, it has participated in sabotage acts, in diversionary actions, in encircling the enemy, and in applying the scorched earth policy. ... On several occasions and in cooperation with guerrillas, it has taken part in combat. ${ }^{76}$

Another lengthy example of active popular support comes from the FMLN insurgency in El Salvador. Here, a commander of the ERP faction of the insurgency indicated:

\footnotetext{
${ }_{73}$ Mark Irving Lichbach, The Rebel's Dilemma (Ann Arbor: The University of Michigan Press, 2009), 17-18.

${ }^{74}$ This notion of needing to transform inputs into outputs is found in Nathan Leites and Charles Wolf, Jr., Rebellion and Authority: An Analytic Essay on Insurgency Conflict (Santa Monica: RAND Corporation, 1970).

${ }^{75}$ Gabriela Tarazona-Sevillano, "The Organization of Shining Path," in David Scott Palmer ed., Shining Path of Peru (New York: St. Martin's Press, 1992), 182.

${ }^{76}$ A Vietminh training document, cited in, Bard E. O'Neill, Insurgency and Terrorism: Inside Modern Revolutionary Warfare (Dulles: Brassey's Inc., 1990), 72.
} 
Essentially, it was the local people who supplied us. We created various supply networks and also networks of information. Teenagers also participated in local military activity, displaying propaganda and laying contact bombs. There were various levels of militia participation. Some might be mobilized for activities for two, three, or five days - they would participate and then return to their homes. Others would join us for two weeks of a month, depending on whether an operation was planned. ${ }^{77}$

As a final example, during the resistance to the Soviets in Galicia, Ukraine, it was noted that:

Neither the underground OUN nor the UPA could have survived without support from the general population, for it was only the villagers who could provide the underground movement with food, clothing, occasional shelter and information. Without these essentials, the underground would have been incapable of simple physical survival. ${ }^{78}$

Popular support, as was noted, is actually transferred to the insurgency as a composite of material, human, and monetary resources, as well as in the form of loyalty, information, and non-disclosure of insurgent activities to the regime. Consequently, each individual that supports an insurgency supplies some amount of labour, material, money, or loyalty to the insurgency. The more popular support that is provided by the population to a rebel group, the more capacity an insurgency will command relative to the forces of the counterinsurgency. In this sense, "the richest source of power to wage war lies," as Mao Tse-Tung puts it, "in the masses of the people." ${ }^{79}$ As an insurgent group's capacity increases, so does the overall strength of the insurrection. For a guerrilla movement,

\footnotetext{
${ }^{77}$ Anonymous interview respondent, cited in, Elisabeth Jean Wood, Insurgent Collective Action and Civil War in El Salvador (New York: Cambridge University Press, 2003), 124.

${ }^{78}$ Alexander Motyl, "The Organized Ukrainian Resistance Movement," cited in, Roger D. Petersen, Resistance and Rebellion: Lessons from Eastern Europe (New York: Cambridge University Press, 2006), 216.

${ }^{79}$ Mao Tse-Tung, On Protracted War (Honolulu: University of the Pacific Press, 2001), 105.
} 
popular support is, therefore, crucial because it is a key source of material and qualitative war-fighting and administrative capacity. ${ }^{80}$

In sum, how the support of the population, both active and passive, manifests suggests that popular support matters for successful insurgency because it is a-and perhaps the-primary way that an insurgency can increase its capacity relative to the counterinsurgent forces of the state. Both forms of popular support augment the capacity of an insurgency relative to the regime. Passive support indirectly augments the relative capacity of the insurgency by reducing the amount of information that is available to the counterinsurgency. This lack of information, in turn, renders the counterinsurgent's military activities less effective, and, correspondingly, increases the capacity of an insurgency relative to the state. Active support, on the other hand, augments the relative capacity of an insurgency directly by increasing the amount of human, material, and monetary resources that an insurgency commands.

\section{2 - How much popular support will an insurgency need?}

In this section, I specify the conditions affecting the amount of popular support an insurgency needs in its efforts to challenge and potentially capture the state. Popular support, as was noted, is a source of much-needed capacity for a rebel organization. Because popular support - both active and passive - augments the capacity of an insurgency, a higher level of popular support results in a more powerful insurgent group relative to the state. In this section, I argue that the amount of popular support an insurgency needs is a function of two factors: 1) the strength of the state and 2) the 'price'

\footnotetext{
${ }^{80}$ The primary role of factors internal to a state in insurgent organizational development is well-noted in Nathan Leites and Charles Wolf, Jr., Rebellion and Authority: An Analytic Essay on Insurgency Conflict (Santa Monica: RAND Corporation, 1970).
} 
and availability of capacity augmenting substitutes to popular support, such as external support and lootable natural resources. In particular, insurgencies that are challenging more powerful states will demand more popular support, because a rebellion will, other things being equal, need to be more capable if it is to militarily defeat a more powerful opponent. However, when other capacity augmenting inputs are cheaper than popular support, an insurgent group will demand less popular support and rely, instead, on the alternative sources of capacity. Relatively cheap and available capacity-augmenting substitutes lessen an insurgent group's demand for popular support because an insurgency can grow materially stronger through less cost by purchasing the cheaper capacity augmenting input. The core point is that an insurgent group's demand for popular support is not, in any direct sense, a function of its ability to obtain it. Theoretically, a rationally calculating insurgent group will demand enough capacity augmenting support to provide them with a good chance of defeating the regime and will also pursue the cheapest source of capacity, be it popular support, resource rents, or external support.

State capacity plays a central role in both the outbreak and success or failure of an insurgency. As Lenin noted in One of the Fundamental Questions of the Revolution, "The basic question of every revolution is that of state power. ... The question of power cannot be evaded or brushed aside, because it is the key question determining everything in a revolution's development." ${ }^{81}$ Lenin's insight about the central role of the state in the course of insurgency and revolution is borne out by both theoretical and empirical research. Theda Skocpol, for example, argued that the successful social revolutions in

\footnotetext{
${ }^{81}$ V.I. Lenin, "One of the Fundamental Questions in the Revolution," cited in, Jeff Goodwin, No Other Way Out: States and Revolutionary Movements, 1945-1991 (Cambridge: Cambridge University Press, 2003), 42. Emphasis in the original work.
} 
France, Russia, and China all required a weakening of the central state. ${ }^{82}$ Similarly, Jeff Goodwin argued that a combination of poor governance structures, exclusionary politics, and, importantly, weak state capacity creates the most fertile conditions for successful revolution. ${ }^{83}$ The central role of state capacity in the onset and outcome of revolutions is also readily apparent empirically. Large- $\mathrm{N}$ empirical studies have found that weak state capacity is significant and positively correlated with the outbreak of civil wars. ${ }^{84}$ An extensive comparative study of has also found that the loss of American military support and a sudden weakening of the state's capacity in Cuba in the 1950s and Nicaragua in the 1970s also coincided with two of the only successful revolutions in Latin American. ${ }^{85}$ Strong states, then, tend to be able to deter and successfully repress insurgent challengers, while weak states tend to be more easily plagued and overthrown by insurgent violence and revolution.

A rationally calculating insurgency will, typically speaking, demand as much popular support as it needs in order to defeat the state that it is challenging. ${ }^{86}$ The amount of popular support that an insurgency needs in order to defeat the state is, therefore, highly variable and is conditioned by the strength of the state. Learned practitioners of insurgency have posited a wide range of necessary levels of popular support. Mao TseTung, for example, observes that only 15 to 25 percent active support amongst the

\footnotetext{
${ }^{82}$ Theda Skocpol, States and Social Revolutions: A Comparative Analysis of France, Russia, and China (Cambridge: Cambridge University Press, 2008).

83 Jeff Goodwin, No Other Way Out: States and Revolutionary Movements, 1945-1991 (Cambridge: Cambridge University Press, 2003), 28-29.

${ }^{84}$ James D. Fearon and David Laitin, "Ethnicity, Insurgency, and Civil War," The American Political Science Review, Vol. 97, no. 1 (2003), 75-90; Cullen S. Hendrix, "Head for the Hills? Rough Terrain, State Capacity, and Civil War Onset," Civil Wars, Vol. 13, no. 4 (2011), 345-370.

${ }^{85}$ Timothy Wickham-Crowley, Guerrillas and Revolutions in Latin America: a Comparative Study of Insurgents and Regimes since 1956 (Princeton: Princeton University Press, 1993), 312.

${ }^{86}$ A similar notion, that the required strength of the insurgency is conditioned by the strength of the state, is found in Gordon H. McCormick, Steven B. Horton, and Lauren A Harrison, "Things Fall Apart: The Endgame Dynamics of Internal Wars," Third World Quarterly, Vol. 28, no. 2 (2007), 323.
} 
population was needed in order for the Communist insurgency to prevail decisively over the Japanese.$^{87}$ In a Latin American context, Abraham Guillen notes, in contrast, that a "great majority," or somewhere around 80 percent of the population, would be need to support the insurgency in order for the guerrillas to stand against the forces of state. ${ }^{88}$ Finally, during the Arab Revolt against the Ottoman Turks, T.E. Lawrence posited that, with just 2 percent of the population actively supporting the insurgency and 98 percent passively sympathetic, "final victory seemed certain." 89

In these three cases, the extent of popular support deemed necessary for successful insurgency generally co-varies with the capacity of the states that are being challenged. Of the three examples, the strongest states were in Latin American, where Abraham Guillen advocated for the highest level of required popular support. The Japanese expeditionary army in China was far flung, meaning that the costs of projecting its capacity over distance would have diminished its functional strength in China. ${ }^{90}$ Thus, Mao predicted that only between 15 and 25 percent active popular support was needed to defeat the counterinsurgent forces. Finally, the Turkish forces in Arabia were materially weak and overextended, while the Turkish state was also simultaneously fighting a Great Power war. Thus, the Turkish capacity in Arabia was generally very low, and so the Arab insurgency required only a very minimal level of active popular support in order to be victorious. While these estimates are certainly heuristic, their co-varying relationship with the strength of the state is strongly suggestive of the idea that an insurgency's

\footnotetext{
${ }^{87}$ Mao Tse-Tung, On Guerrilla Warfare (New York: Dover Publications, Inc., 2005), 27.

${ }^{88}$ Abraham Guillen, cited in, Ben Connable and Martin Libicki, How Insurgencies End (Santa Monica: RAND Corporation, 2010), 29.

${ }^{89}$ T.E. Lawrence, Seven Pillars of Wisdom (London: Vintage Books, 2008), 202.

${ }^{90}$ Eric Jardine, "Controlling Territory and Population during Counterinsurgency: State Security Capacity and the Costs of Power Projection," Civil Wars, Vol. 14, no. 2 (2012), 228-253.
} 
demand for popular support is conditioned by the strength and capacity of the state. Stronger states necessitate stronger insurgencies, all else being equal. Weaker states, in contrast, can be militarily defeated by generally weaker insurgent organizations.

Strategically minded insurgent groups, as a result, should tend to demand sufficient active and passive popular support to provide a reasonable chance of victory in a conflict.

A related intuition that helps to determine the validity of the core notion is that a rebel group that seeks active and passive support from a segment of the population that is too small relative to the strength of the state should either be compelled to expand its efforts at mobilizing the population or should lose in the conflict. In theoretical terms, this notion is generally consistent with Robert H. Dix's observation that broad-based "negative coalitions" among multiple social strata are necessary for successful revolution, as well as Charles Tilly's point that alliances between revolutionary groups in both town and countryside are needed for successful revolt. ${ }^{91}$ More generally, yet in a similar vein, John A. Booth has observed that, "Coalitions among diverse social sectors with different grievances and aspirations have been typical of successful revolutionary movements; single-class or single-group movements have commonly failed." ${ }^{92}$

The related intuition is also present historically. In Indonesia, for example, the communist PKI emphasised the mobilization of urban workers, squatters, youth, estate labourers, and low state functionaries. As Rex Mortimer points out, "Even if the PKI had fully mobilized and organized these groups, they would not have constituted a sufficient base of support for a challenge to the established order. [As a result,] the PKI felt obliged

\footnotetext{
${ }^{91}$ Robert H. Dix, "Why Revolutions Succeed \& Fail," Polity, Vol. 16, no. 3 (1984), 423-446; Charles Tilly, "Town and Country in Revolution," in John Wilson Lewis, ed., Peasant Rebellion and Communist Revolution in Asia (Stanford: Stanford University Press, 1974), 271-302.

92 John A. Booth, The End and The Beginning: The Nicaraguan Revolution (Boulder: Westview Press, 1985), 3-4.
} 
to seek a wider clientele among the peasants." ${ }^{93}$ The support base of the Communist Party in Malaya was clustered in the Chinese ethnic group. The Chinese composed roughly 34 percent of the population of Malaya, yet filled 90 to 95 percent of the Communist Party ranks. ${ }^{94}$ The Malayan insurgency was unable to prevail in their conflict against the British counterinsurgency, partially at least because of its limited support base. ${ }^{95}$ Similarly, within Sri Lanka, the LTTE drew its active and passive popular support from the Tamil population, which is only 10 or 11 percent of Sri Lanka's total population. Like the communist insurgency in Malaya, the LTTE could not mobilize enough popular support within Sri Lanka to defeat the state, although the considerable diaspora support did prolong the conflict considerably. ${ }^{96}$ The idea that insurgent groups need to form broadbased coalitions in order to win supports the primary notion that the strength of the state determines how much popular support an insurgent groups needs in order to pose an real challenge to the regime.

An insurgency needs and demands popular support largely because it is a capacity augmenting input. In some cases, however, an insurgency can obtain capacity from sources other than the population. Sometimes an insurgency can be provided with capacity from state-sponsors, diaspora groups, or other non-state actors, as was the case with the Mujahideen in Afghanistan, the Vietcong in Vietnam, and the LTTE in Sri

\footnotetext{
${ }^{93}$ Rex Mortimer, "Traditional Modes and Communist Movements: Change and Protest in Indonesia," in John Wilson Lewis, ed., Peasant Rebellion and Communist Revolution in Asia (Stanford: Stanford University Press, 1974), 105-106.

${ }^{94}$ For various estimates about the percentage of the MRLA that was populated by ethnic Chinese see, for example, Robert B. Asprey, War in the Shadows: The Guerrilla in History, vol. 1 (Lincoln: Backinprint.com, 2002), 564; John Coates, Suppressing Insurgency: An Analysis of the Malayan Emergency, 1948-1954 (Boulder: Westview Press, 1992), 49.

95 Kelly M. Greenhill and Paul Staniland, "Ten Ways to Lose at Counterinsurgency," Civil Wars, Vol. 9, no. 4 (2007), 403.

${ }^{96}$ C. Christine Fair, "Diaspora Involvement in Insurgencies: Insights From the Khalistan and Tamil Eelam Movements," Nationalism and Ethnic Politics, Vol. 11, no.1 (2005), 125-156.
} 
Lanka ${ }^{97}$ Insurgent organizations can also obtain capacity by trading lootable natural resources, such as diamonds, coltan, timber, or illegal crops, for capacity augmenting inputs, as the Taliban insurgency in Afghanistan, the FARC rebels in Columbia, and the RUF in Sierra Leone have all done. ${ }^{98}$ For an insurgent group, both external support and lootable natural resources are substitutes for popular support because they will increase the capacity of the insurgency relative to the state.

Generally, with its demand for capacity conditioned by the strength of the regime, an insurgent group should aim to augment its strength relative to the state that it is challenging in the cheapest way possible. The pursuit of cheap capacity means that if the cost (measured as an amalgam of political or fiscal capital) of obtaining popular support is cheaper than the cost of obtaining a supplementary form of support, then an insurgency will try to secure more popular support. Alternatively, if the cost of a supplementary form of support, such as external support or lootable resources, is cheaper than popular support, then an insurgent group will limit their pursuit of popular support and try and secure the supplementary form of capacity instead. Basically, as the relative cost of substitutes to popular support declines, the amount of popular support that an insurgency will demand falls as well, while the insurgency's pursuit of other forms of support will rise.

\footnotetext{
${ }^{97}$ Jeffrey Record, for example, argues that external support is key to successful insurgency. Jeffrey Record, Beating Goliath: Why Insurgencies Win (Washington: Potomac Books, 2009); Daniel Byman, Peter Chalk, Bruce Hoffman, William Rosenau, and David Brannan, Trends in Outside Support for Insurgent Movements (Santa Monica: RAND Corporation Publishing, 2001).

${ }^{98}$ On the nexus between natural resources and civil conflict see, for example: Paul Collier and Anke Hoeffler, "Greed and grievance in civil war," Oxford Economic Papers, Vol. 56, no. 4 (2004), 563-595; Macartan Humphreys, "Natural Resources, Conflict, and Conflict Resolution: Uncovering Mechanisms," Journal of Conflict Resolution, Vol. 49, no. 4 (2005), 508-537; Michael Ross, "How Do Natural Resources Influence Civil War? Evidence from Thirteen Cases," International Organization, Vol. 58, no. 1 (2004), 3567; James D. Fearon, "Primary Commodity Exports and Civil War," The Journal of Conflict Resolution, Vol. 49, no. 4 (2005), 483-507.
} 
In this section, I have argued that the amount of popular support an insurgency needs and demands from the population is conditioned by two factors: the strength of the state and the relative cost of supplementary forms of capacity for an insurgency. Stronger states generally necessitate stronger insurgencies, which require higher levels of popular support. Cheaper supplements to popular support, such as nearly costless external support or cheap lootable natural resources, means that the pursuit of popular support is a less attractive option for an insurgent organization. Knowing, in general terms at least, how much popular support an insurgency will demand begs another question: how does an insurgent group obtain popular support?

\section{3 - How do Insurgent Organizations Obtain the Support of the Population?}

In this section, I argue that the best way to conceptualize how an insurgency obtains popular support is to use a market exchange model, similar in form to that which is used to determine the demand and supply of a consumer good. ${ }^{99}$ From this perspective, individuals within the population supply active and passive support to an insurgent group, provided that their preference for compensation is satisfied. Individual preferences vary across the population, with some people desiring a lot of compensation in order to provide a given level of support and others demanding less compensation in exchange for

\footnotetext{
${ }^{99}$ On the idea that an insurgency exists in an exchange relationship with the population, see Timothy $\mathrm{P}$. Wickham-Crowley, "The Rise (And Sometimes Fall) of Guerrilla Governments in Latin America," Sociological Forum, Vol. 2, no. 3 (Summer 1987), 473-499; Timothy P. Wickham-Crowley, Exploring Revolution: Essays on Latin American Insurgency and Revolutionary Theory (Armonk: M.E. Sharpe, Inc., 1991); Jeffrey Race, War Comes to Long An: Revolutionary Conflict in a Vietnamese Province (Berkeley: University of California Press, 2010); Joel S. Migdal, Peasants, Politics, and Revolution: Pressures towards Political and Social Change in the Third World (Princeton: Princeton University Press, 1974); Samuel Popkin, The Rational Peasant: The Political Economy of Rural Society in Vietnam (Berkeley: University of California Press, 1979). These earlier exchange theories of popular support and insurgency did not consider how the exchange relationship might affect the rebel group's organizational and administrative structures.
} 
the same amount of proffered support. Hence, as I outline below, differential preferences among individuals within the population are at the core of the exchange theory of popular support for an insurgency as I develop it.

In what follows, I first outline the central role that preferences of the population play in the exchange relationship. I then outline the two methods that an insurgency can use to secure higher levels of popular support, namely, the supply of services and goods as payment to the population (remunerative compensation) or the manipulation of the preferences of the population through coercion and propaganda (preference manipulation tactics). Next, I provide historical examples of the first method and a graphical model that captures the effect of service and good provision by an insurgent group on the amount of popular support received. Following that, I outline the role that the threat of coercion and the application of propaganda can have on the willingness of the population to supply popular support to an insurgent group. Here again, I provide historical examples to substantiate the various points that are made and present another graphical model that distils the effects of insurgent coercion and propaganda on the population's supply of support to an insurgency.

The differential preferences of the population are, as was noted, at the core of the exchange relationship. Each individual (or potentially each familial, tribal, or political grouping) tends to deal directly with the insurgency as a whole and makes the decision to provide popular support on the basis of the bundle of payment that the insurgency supplies and their unique quantity of compensation demanded. The core implication of the population's differential preferences towards an insurgency is that some individuals will demand more payment in exchange for providing support to the rebellion, while 
others will demand less based largely upon their privately held preferences. Those individuals whose preferences align with an insurgency or, potentially, those whose individual preferences are strongly against a regime will tend to demand less payment in exchange for the provision of support. Individuals whose preferences lie strongly with the regime or against the insurgency will tend to demand more payment, but can still be coopted into passively or actively supporting an insurgent group if the amount of remuneration provided by the guerrilla organization is sufficient to meet their preferences for compensation. ${ }^{100}$

Given the presence of differential individual preferences, an insurgent group can gain popular support, I posit, through two complementary and non-exclusive methods. First, an insurgency can satisfy an individual's demand for payment by providing benefits to the population in exchange for their supply of support. Such benefits include both services and material and ideational goods. Secondly, an insurgency can manipulate the preferences of individuals within the population, thereby lowering the quantity of benefits that need to be provided in order to secure a given level of popular support. Preferences can be manipulated both positively through propaganda and negatively through the use of coercion and the threat of violence. When effectively used by an insurgency, both propaganda and coercion decrease the amount of payment that an individual will require in exchange for supplying a certain level of support, although neither method of preference manipulation necessarily eliminates the central role of positive inducements in the exchange process. ${ }^{101}$ The main implication of this exchange relationship is that the

\footnotetext{
${ }^{100}$ Nathan Leites and Charles Wolf, Jr., Rebellion and Authority: An Analytic Essay on Insurgency Conflict (Santa Monica: RAND Corporation, 1970).

${ }^{101}$ On the role of positive and negative inducements for participation in an organization see, for example, Amitai Etzioni, A Comparative Analysis of Complex Organizations (New York: The Free Press, 1975), 3-22.
} 
level of popular support that an insurgency obtains is contingent upon both the amount of payment its supplies to the people and the preferences of the population, which can be manipulated somewhat through coercion and propaganda. More payment and/or more favourable preferences result in more proffered popular support, while, on the contrary, less payment and/or more unfavourable preferences result in a lower level of popular support for the insurgency.

\subsection{1 - Method 1: Providing Remunerative Compensation to the Population in Exchange} for Support

The first method by which an insurgency can secure popular support, as outlined above, is to provide remunerative compensation to the population. One form of remuneration is for an insurgent group to provide services to the population in rebel-controlled areas or areas of weak state administration. The types of services that are frequently provided range from security provision, to justice administration, to the supply of health care and education to the local people.

Historical examples of service provision as an effective method for an insurgent group to obtain popular support are quite plentiful. As Timothy Wickham-Crowley notes of insurgencies in Latin America, "Guerrillas consolidated their authority over the peasantry as they began to provide the full array of social-contact 'services' to the local populace: defense, police-administration, and welfare." ${ }^{102}$ Similarly, in southern Lebanon, Hezbollah provides extensive services to the Shiite community and is

\footnotetext{
102 Timothy P. Wickham-Crowley, "The Rise (And Sometimes Fall) of Guerrilla Governments in Latin America," Sociological Forum, Vol. 2, no. 3 (Summer 1987), 482.
} 
characterised as the "largest non-state provider of healthcare and social services." ${ }^{103}$ In the Western Sahara, the Polisario Front provides many services in order to guarantee that the population supports the insurgency, and does so by ensuring that "each [refugee] camp has its [own] day-care centers, primary schools, youth centers." ${ }^{104}$ In Afghanistan, in an effort to secure higher levels of popular support, the Taliban insurgency has established "courts, alternative schools, and other services to demonstrate their capacity to deliver services where the government has failed to [do so]." ${ }^{105}$ In Ethiopia, the TPLF insurgency routinely supplied services to the population in order to obtain higher levels of popular support. As John Young notes, "The Front attempted to gain the confidence and ultimately the support of peasants by their highly disciplined behaviour, displays of self-sacrifice, and commitment to the peasants' interest. In this early period peasants report, for example, how TPLF cadres arranged a doctor's visit for a sick man, or helped a widow with her ploughing." ${ }^{106}$ Likewise, in neighbouring Eritrea, "providing health care for peasants and pastoralists in areas which had no medical facilities generated significant rural support" for the EPLF insurgency. ${ }^{107}$ In the Philippines, the CPP expanded its level of popular support "by addressing a number of key issues that the government has either been unwilling or unable to resolve. Agrarian reform, social services, rudimentary health care, law enforcement, justice, and other local services are being provided in an effective,

\footnotetext{
${ }^{103}$ Bryan R. Early, "'Larger than a Party, Yet Smaller than a State,'" World Affairs, Vol. 168, no. 3 (Winter 2006), 115.

${ }^{104}$ Jon Lee Anderson, Guerrillas: Journeys in the Insurgent World (Toronto: Penguin Books, 2004), 13.

${ }^{105}$ Neil A. Englehart, "A Tale of Two Afghanistans: Comparative Governance and Insurgency in the North and the South," Asian Survey, Vol. 50, no. 4 (2010), 752.

${ }^{106}$ John Young, Peasant Revolution in Ethiopia: The Tigray People's Liberation Front, 1975-1991 (New York: Cambridge University Press, 2006), 103.

${ }^{107}$ David Pool, From Guerrillas to Government: The Eritrean People's Liberation Front (Athens: Ohio University Press, 2001), 81.
} 
if sometimes brutal fashion, by the rebels." ${ }^{108}$ In El Salvador, the FMLN developed political organizations around the population. "The purpose of these organizations," notes Elisabeth Wood, "was to provide food and health care to local residents as well as guerilla forces, typically through cooperative buying of seeds and fertilizer and marketing of surplus as well as the collective cultivation of some land for communal consumption." ${ }^{109}$

Another form of payment that an insurgency can use to compensate the population for supplying popular support is the provision of material goods, such as food, tools, medicine, or redistributed land, as well as more ideational goods, such as praise and social acceptance. In the Tamil-controlled areas of Sri Lanka, for example, both material and ideational goods were often provided to the population in exchange for popular support of the insurgency, particularly when families supplied recruits to the LTTE. According to several Tamil respondents interviewed by Jannie Lilja, the families of recruits received all sort of material benefits, ranging from land to physical protection to foodstuffs, as well as more ideational praise and social acceptance. ${ }^{110}$ Similarly, amidst a complex melange of factors, one collaborator with the FMLN insurgency in El Salvador noted that supporting the insurgency was necessary "because at that time you couldn't get anything to eat in town. [...] They [the guerrillas] brought us the food, because they could get it. They brought everything: corn, rice, beans. [...] Once we started to support them,

\footnotetext{
${ }^{108}$ Gregg R. Jones, Red Revolution: Inside the Philippine Guerrilla Movement (Boulder: Westview Press, 1989), 12.

${ }^{109}$ Elisabeth Jean Wood, Insurgent Collective Action and Civil War in El Salvador (New York: Cambridge University Press, 2003), 126.

${ }^{110}$ Jannie Lilja, "Trapping Constituents or Winning Hearts and Minds? Rebel Strategies to Attain Constituent Support in Sri Lanka," Terrorism and Political Violence, Vol. 21, no. 2 (2009), 316.
} 
yes, they gave us food." ${ }^{111}$ The Polisario Front in the Western Sahara also provided, in exchange for popular support, the bulk of the material goods available to the population, including such basic essentials as housing, food, clothing, water, and electricity. ${ }^{112}$ Moreover, as Antonio Giustozzi notes, in Afghanistan, "the Taliban sometimes paid villagers cash (reportedly US\$ 15-55) to harass foreign and government troops with occasional rocket attacks and shooting [sic]."113

The first general method that an insurgent group can use to secure popular support, then, is to pay the people with services and goods in exchange for their supply of active and passive popular support to the insurgency. To perhaps state the obvious, rebel groups will need to provide things that the population lacks in exchange for their support, so the insurgency will not trade money for money, but will trade justice administration for shelter or food or money for manpower.

To obtain more popular support, an insurgency needs to increase the amount of payment that it provides. The effect of this strategy is captured in Figure 2.1. In Figure 2.1, Curve S1 is the population's supply curve. It indicates how much popular support (PS) the population will provide to an insurgency in exchange for a given bundle of payment (RC), which is composed of insurgent-provided services and goods.

\footnotetext{
${ }^{111}$ Cited in, Jocelyn S. Viterna, "Pulled, Pushed and Persuaded: Explaining Women's Mobilization into the Salvadoran Guerrilla Army," American Journal of Sociology, Vol. 112, no. 1 (July 2006), 32.

112 Jon Lee Anderson, Guerrillas: Journeys in the Insurgent World (Toronto: Penguin Books, 2004), 13.

${ }^{113}$ Antonio Giustozzi, Koran, Kalashnikov and Laptop: The Neo-Taliban Insurgency in Afghanistan (New York: Columbia University Press, 2008), 41.
} 


\section{Figure 2.1. The Insurgency's Exchange of Services and Goods for Popular Support}

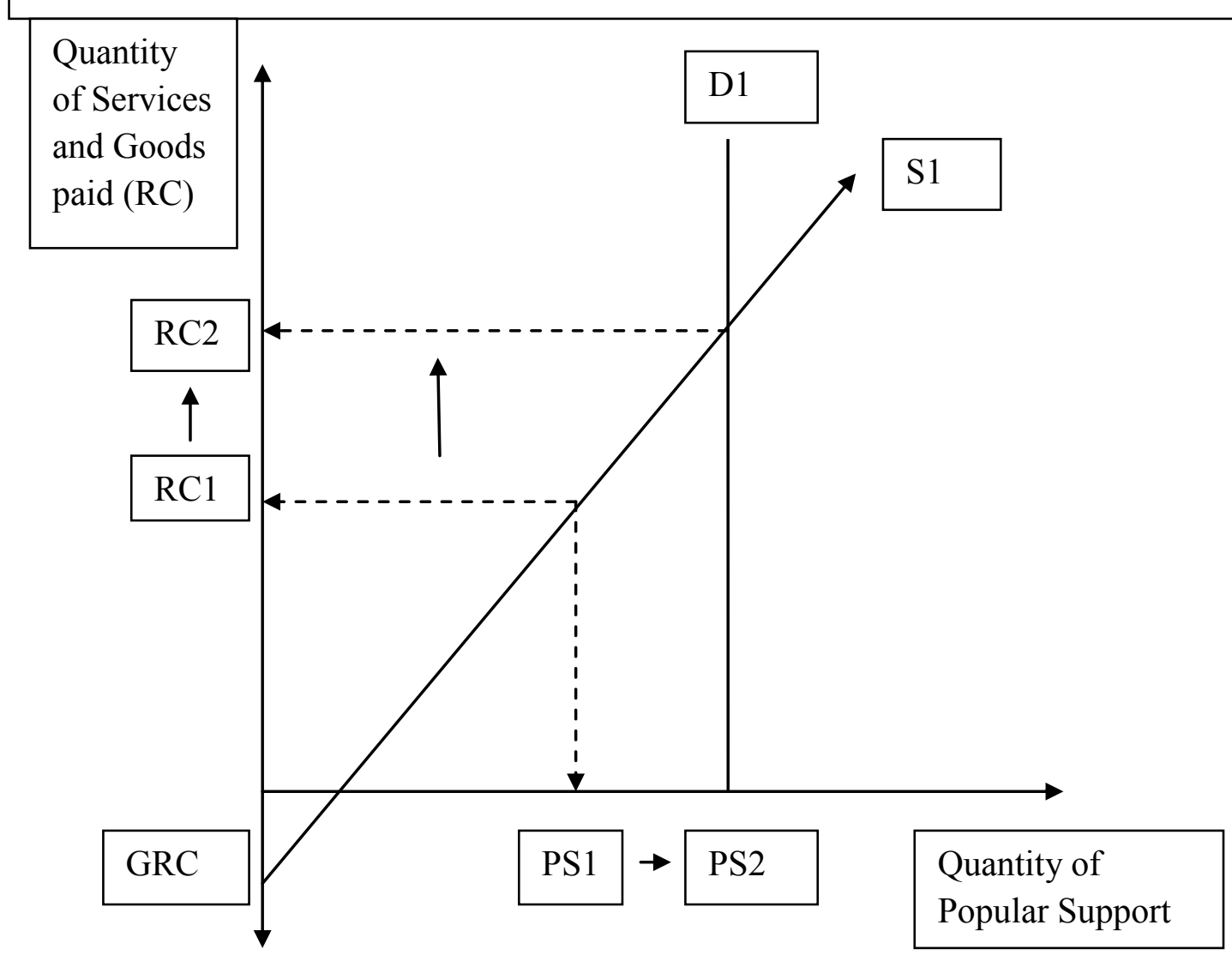

Curve S1 is sloped upwards so as to capture the differential preferences that each individual within population has toward supplying support to a rebel group in exchange for insurgent payment. The $\mathrm{S} 1$ curve intersects the $\mathrm{x}$-axis at a positive value because there are likely to be some individuals within the population who will pay the insurgency for the opportunity to provide the rebel group with their active and passive support. These individuals are the "fanatics" and "first movers" that start rebel organizations, often at great personal cost. ${ }^{114}$ It is from these individuals that an insurgent group obtains its initial material resources that it can then spend, in later periods, to secure even higher

\footnotetext{
${ }^{114}$ For an interesting account of the problem of "fanatics and first actors", see Roger D. Peterson, Resistance and Rebellion: Lessons From Eastern Europe (Cambridge: Cambridge University Press, 2006), 272-295.
} 
levels of popular support. In general, those individuals that are closer to origin have a strong preference for the insurgency and will provide support without much compensation. Near to the end of the S1 curve, that is, furthest from origin, are the people who have a very strong preference against the insurgency, such as regime elites, or individuals in government-controlled areas. ${ }^{115}$ For an insurgency to get the popular support of these people, it would need to provide a lot of remunerative compensation, but a large enough bundle of payment could still persuade them to support a rebellion.

Curve D1, in Figure 2.1, is the insurgency's demand curve. It captures the insurgency's demand for popular support as an often crucial input into the process of insurrection. It is perfectly inelastic, and hence vertical, because an insurgent group's needed amount of popular support, and hence the amount it demands, is not a function of the price of that support. Instead, a rebel group's demand for popular support is determined exogenously and is, as was noted, a function of the strength of the state and the price and availability of substitutes for popular support. The main idea is that curve D1 illustrates the amount of popular support that an insurgency needs in order to confront the state both politically and militarily. At the intersection of curves D1 and S1, you have the point at which the insurgency pays the necessary price in services and goods (RC2) and receives, in exchange, a sufficient quantity of popular support (PS2) to effectively challenge the regime.

An insurgency may demand sufficient popular support to effectively challenge a regime, but this does not necessarily mean that it will have the ability to provide the needed level of services and goods as compensation to the population. For example, as

\footnotetext{
${ }^{115}$ On territorial control and the behaviour of the population see Stathis N. Kalyvas, The Logic of Violence in Civil War (New York: Cambridge University Press, 2009).
} 
shown in Figure 2.1, if an insurgency can only provide some amount of services and goods to the people ( $\mathrm{RC} 1)$, then the point of intersection between that line and the population's supply curve, S1, illustrates the amount of popular support (PS1) that an insurgency receives in exchange. Because this amount is less than is actually demanded (the amount needed for a rebellion to effectively challenge the state), an insurgency has an incentive to attempt to increase its ability to supply more services and goods and thereby move its provision of payment upwards until it is providing the necessary amount of services and goods (RC2) to the people and receiving the sufficient amount of popular support (PS2) in exchange. How an insurgency can provide more services and goods is the focus of chapter 3 .

\subsection{2 - Method 2: Manipulating the Preferences of the Population through Coercion and} Propaganda

In addition to satisfying each individual's preference for compensation through the provision of services and goods, an insurgency can also use a combination of targeted coercion and propaganda to secure more popular support by manipulating the preferences of individuals within the population. The use of preference manipulation tactics by an insurgency essentially makes people more disposed towards supporting the rebellion, which means the group needs to provide less payment in the form of remunerative compensation for any given level of popular support.

Coercive methods, particularly the threat and commission of well-targeted physical violence, increase the downside risk that an individual faces for not supporting 
an insurgency. ${ }^{116}$ Generally, as the costs of not supporting the insurgency rise, the amount of remunerative compensation that an insurgency needs to provide as payment in exchange for the active or passive support of the population declines. Essentially, a rebel group can use the credible threat of violence against the population to discount the amount of positive benefits that need to be provided in order to achieve a given level of popular support. By making non-support a costly option, an insurgency can compel individuals within the population to accept less payment than they would otherwise demand in exchange for their supply of active and passive support. As Stathis Kalyvas puts it, "violence is primarily a resource rather than a final product; it is intended to shape the behavior of a target audience by altering the expected value of a particular action." 117

A peasant from Hoi $\mathrm{Cu}$ village in Vietnam during the Viet Minh's resistance to the French describes the process: "[The people] were afraid of the Viet Minh ... and continued to contribute money to the resistance. ... Those who refused to contribute money to the Viet Minh and argued with them were kidnapped at night, blindfolded and buried alive in the fields. ... the villagers, therefore, were frightened to death and had to make contributions to the resistance." ${ }^{118}$ Similarly, during the Venezuelan revolution in the 1960 s, one peasant noted, "When the guerrillas were relatively unknown, a peasant could coexist with them, getting good prices for his corn and hens, though most of those cooperating did so for fear of being killed [by the insurgency]." ${ }^{119}$ During the Zimbabwe

\footnotetext{
${ }^{116}$ Stathis N. Kalyvas and Matthew Adam Kocher, "How 'Free' is Free Riding in Civil Wars? Violence, Insurgency, and the Collective Action Problem," World Politics, Vol. 59, no. 2 (2007), 177-216.

${ }^{117}$ Stathis N. Kalyvas, "The Paradox of Terrorism in Civil War," Journal of Ethics, Vol. 8, no 1 (2004), 100.

${ }^{118}$ Cited in, David W.P. Elliot, The Vietnamese War: Revolution and Social Change in the Mekong Delta, 1930-1975 (Armonk: M.E. Sharpe,2007), 52.

${ }^{119}$ Cited in, Norman Gall, "Venezuela and the Continental Revolution," The New Leader (April 1965), 5, cited in, Timothy P. Wickham-Crowley, "The Rise (And Sometimes Fall) of Guerrilla Governments in Latin America," Sociological Forum, Vol. 2, no. 3 (Summer 1987), 484. Emphasis added.
} 
war of independence, ZANU guerrillas frequently used coercion to extract support and resources from the population. One storeowner from Nyamuzuwe, for example, received a letter from the guerrillas stating that, "If we didn't meet their requests (for groceries, soft drinks, money) we'd be asked to contribute more money for a bazooka and then comrades could kill us." ${ }^{120}$ Indeed, one study on rebel recruitment into the insurgency in Sierra Leone, notes that as many as "88 percent of the fighters in the RUF describe being abducted." ${ }^{121}$ Later, in testimony given to the Special Court of Sierra Leone, Charles Taylor clearly outlined the role coercion played in the recruitment of manpower during the insurgency:

Look, whenever you are fighting war, the strength of any revolution, it depends on the manpower, the manner in which you carry out your recruitment ... They have to recruit whoever they meet: old people, young people, young girls, young boys. They have to join the revolution and if they refuse to join, it means they are classified to be enemies. So you have to compulsorily recruit these people. ${ }^{122}$

Another tactic that an insurgency can use to manipulate the preference of the people, and so achieve popular support at a lower price, is to positively influence people's preferences toward a rebel group through the generous application of propagandistic appeals, such as claims that disparage the regime's actions or that laud the rebellion. By shifting individual preferences either away from the regime or toward the insurgency, a rebel group's propaganda effort, if effective, decreases the amount of positive inducements that need to be supplied to the population in exchange for a given level of support. Islamist insurgents in Afghanistan, for example, routinely inflate the number of

\footnotetext{
${ }^{120}$ Cited in, Norma J. Kriger, Zimbabwe's Guerrilla War: Peasant Voices (New York: Cambridge University Press, 2008), 107. Parentheses in the original.

${ }^{121}$ Macartan Humphreys and Jeremy M. Weinstein, "Who Fights? The Determinants of Participation in Civil War," American Journal of Political Science, Vol. 52, no. 2 (April 2008), 438.

${ }^{122}$ Charles Taylor, cited in, Ibid.
} 
counterinsurgent casualties in order to make their efforts appear more effective so as to generate more interest among potential recruits. ${ }^{123}$ During the Vietnam War, Vietcong operatives routinely used intensive propaganda sessions to secure higher levels of popular support. Insurgent propaganda, in this case, included both a negative message about state behaviour, intentions, and the probability of counterinsurgent success, as well as a positive message about the virtues, patriotism, and chances of successful insurrection. ${ }^{124}$ Likewise, to obtain popular support during the insurgency in the Philippines during the 1940s, the "Huks told people all about what happened to the Hukbalahap, about how the Americans had 'rewarded' them for their good, anti-Japanese fighting [with persecution and repression]." ${ }^{125}$ In Peru, "Sendero's growth and expansion at the national level is due in part to its political work at the grass roots. ... Sendero's ideology, tailored to its audience, spreads by emphasizing the failures and inadequacies of the present state, the unjust and corrupt nature of the existing socioeconomic order." ${ }^{126}$ Finally, in Ethiopia, one TPLF rebel noted that, "'through our revolutionary songs we are trying to instil confidence in the people themselves, telling them that they are the course of political power and that they will one day destroy their oppressors."'127

\footnotetext{
${ }^{123}$ Chris Lundry, Steven R. Corman, R. Bennett Furlow, and Kirk W. Errickson, "Cooking the Books: Strategic Inflation of Casualty Reports by Extremists in the Afghanistan Conflict," Studies in Conflict and Terrorism, Vol. 35, no. 5 (2012), 369-381.

${ }^{124}$ W.P. Davison, "Some Observations on Viet Cong Operations in the Villages," RAND Research Memorandum, RM-5267/2-ISA/ARPA (July 1967), 14-19.

${ }^{125}$ Silvestre Liwanag, cited in, Benedict J Kerkvliet, The Huk Rebellion: A Study of Peasant Revolt in the Philippines (New York: Rowman \& Littlefield Publishers, Inc., 2002), 175.

${ }^{126}$ Gabriela Tarazona-Sevillano, "The Organization of Shining Path," in David Scott Palmer ed., Shining Path of Peru (New York: St. Martin's Press, 1992), 178-179.

${ }^{127}$ Cited in, John Young, Peasant Revolution in Ethiopia: The Tigray People's Liberation Front, 1975-1991 (New York: Cambridge University Press, 2006), 173.
} 


\section{Figure 2.2. The Insurgency's Manipulation of Popular Preferences Through} Coercion and Propaganda

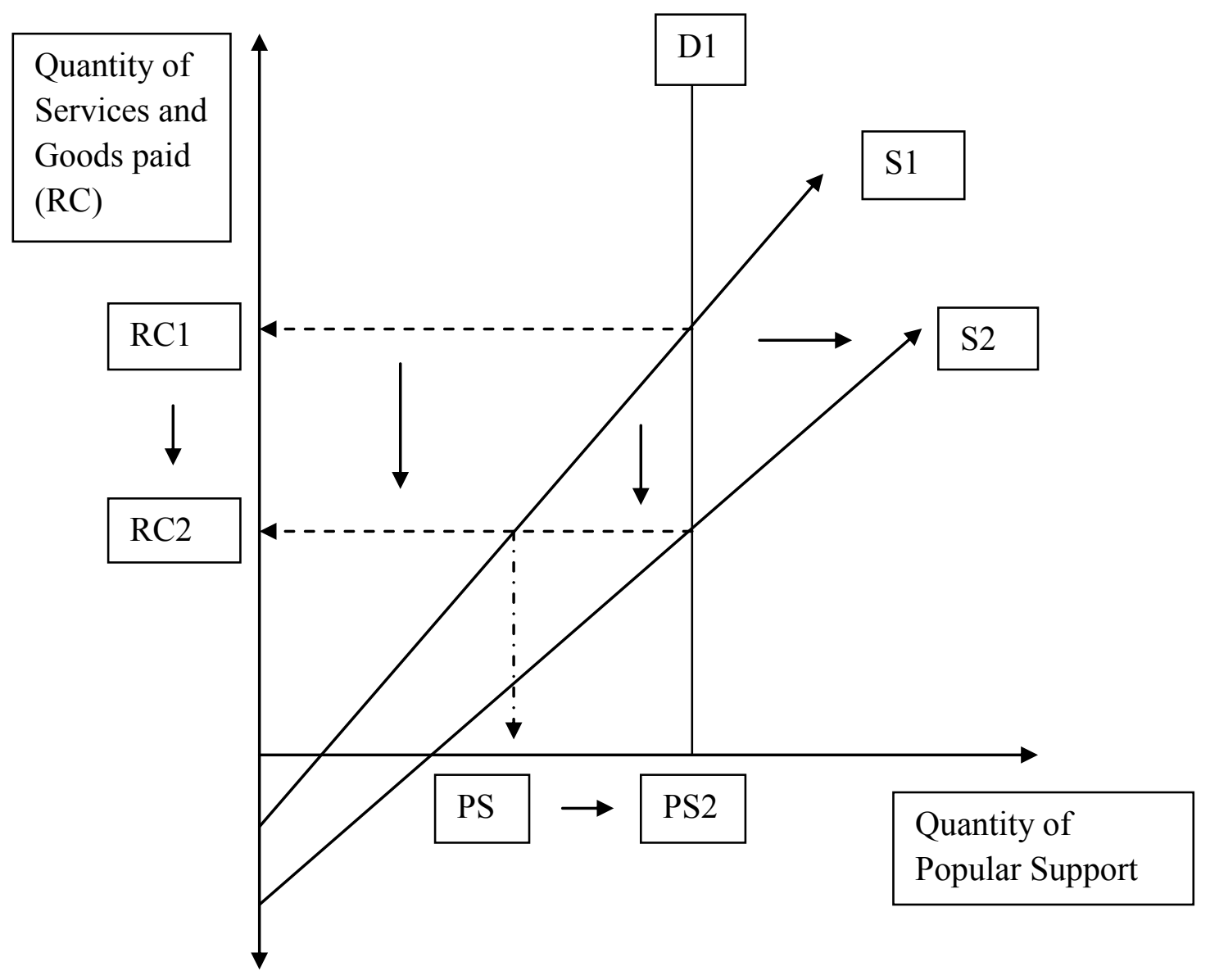

As in Figure 2.1 above, Figure 2.2 has a perfectly inelastic, as in perfectly vertical, insurgent demand curve, D1. The population's initial supply curve (S1) is sloped upwards, so as to capture the presence of differential individual preferences about supporting an insurgency. The intersection of the population's supply curve (S1) and the insurgent's demand curve (D1) results in a point of equilibrium. At this point, the insurgency receives the full amount of active and passive popular support from the population (PS2) that it needs to effectively challenge the state. In exchange, the 
insurgent group has to provide a bundle of remunerative compensation ( $\mathrm{RC} 1)$ as payment to the population.

An insurgent group's use of targeted coercion and propaganda affect the preferences of the population in different ways. The use of targeted coercion results in a shift to the right of the population's supply curve. The use of effectively crafted propagandistic appeals results in a flattening of the population's supply curve. In combination, the effects of both forms of preference manipulation tactics on the population's willingness to supply popular support to an insurgency are complimentary. The effective use of preference manipulation tactics entails that for any given level of remunerative compensation that a rebel group provides, the insurgency receives a larger quantity of popular support.

As depicted in Figure 2.2, if an insurgency is effective at manipulating the preferences of the population through the application of some combination of targeted coercion and the use of propaganda, then the population's supply curve shifts to the right and flattens out, moving from S1 to, say, S2. This shift and rotation basically means that individuals within the population have become more inclined towards the insurgency and will accept less remunerative compensation in exchange for supplying any given level of popular support to the rebel group. From the insurgency's perspective, the price of a given bundle of popular support has gone down. The threat of coercion pushes the supply curve to the right by making non-support of an insurgent group more costly, thereby discounting to zero the amount of remunerative benefits that a person is willing to accept in exchange for supplying a given level of popular support. Graphically, this process is captured by the new intercept of the S2 curve that falls further out along the $\mathrm{x}$-axis than 
the S1 curve. Propaganda flattens the slope of the population's curve by persuading the people that the insurgency is more worth supporting at any given price. As a person's favourable view of the insurgency increases, the amount of remunerative compensation that is demanded in exchange for providing a given level of popular support declines. Once the population's supply curve has moved from S1 to S2, the insurgency's demand curve (D1) now intersects the population's new supply curve (S2) at a lower level of remunerative compensation (RC2). Basically, by both persuading and compelling the population to accept fewer benefits in exchange for a given level of support, the coercive and propagandistic acts of an insurgency reduce the amount of remunerative compensation, in the form of services and goods, that need to be supplied in order to obtain the demanded level of popular support.

Conversely, of course, if the preferences of the population sour and shift against the insurgency, then securing popular support becomes more costly for a rebel group. If, say, an insurgent's prospect of victory over a regime diminishes and this makes people prefer to not support the insurgency and to support, instead, the forces of the state, then there would be a rotation of the population's supply curve that would make it steeper. In Figure 2.2, this would be a shift from S2 to S1. As the population's preference for remunerative compensation increases, the amount of services and goods that an insurgency needs to provide to secure a given level of support increases too, with the amount of services and goods needed to secure an insurgency's demanded level of popular support rising from $\mathrm{RC} 2$ to $\mathrm{RC} 1$.

Likely, the causal effect of both types of preference manipulation tactics is asymmetrical, so that the addition of a cause and its removal have a differently sized 
effect on the baseline preferences of the population. ${ }^{128}$ The addition of a large amount of propaganda shifts the population's preferences in favour of the insurgency (say, by 10 points). However, since the aim of propaganda (like effective advertising) is to have the ideas that are being promoted internalized by the target individual, the cessation of the propaganda campaign will not necessarily result in a backslide in the population's preferences to their original value. Instead, assuming the ideas that are being promoted are internalized to some extent, the people will still support the objectives of the insurgency more than they did before (say, 5 points more), even with the removal of the initial cause.

Coercion likely has a similar, but very distinct effect. Being compelled into supporting an insurgency can result in resentment amongst the population. As long as the credible threat of coercion is maintained, the population will act in the way described above and support the insurgency more freely than their initial preferences would normally allow. If the threat of coercion is removed, the most plausible change in the population's baseline preferences is again asymmetrical. But, in this case, rather than the removal of an insurgent group's use of coercion resulting in less pronounced change in the level of popular support that the population provides to the insurgency, the effect is likely larger than the initial benefits obtained through the threat of violence. In other words, the resentment that might accumulate within the population towards an insurgent group that relies extensively on coercion to mobilize popular support can result in a

\footnotetext{
${ }^{128}$ As Stanley Lieberson puts it, "In examining the causal influence of X1 [an explanatory variable] on $\mathrm{Y}$ [a dependent variable], for example, one has also to consider whether shifts to a given value of $\mathrm{X} 1$ from either direction have the same consequences for $\mathrm{Y}$. ... If the causal relationship between $\mathrm{X} 1$ [an explanatory variable] and $Y$ [a dependent variable] is symmetrical or truly reversible, then the effect on $Y$ of an increase in X 1 will disappear if $X 1$ shifts back to its earlier level (assuming that all other conditions are constant)." Cited in, Gary King, Robert O. Keohane, and Sidney Verba, Designing Social Inquiry: Scientific Inference in Qualitative Research (Princeton: Princeton University Press, 1994), 89-90.
} 
backlash if that coercion or the credible threat of coercion is lessened or removed. For instance, applying coercion might shift the population's supply curve to the right 10 points, making popular support cheaper. In turn, the removal of the credible threat of coercion might shift the population's supply curve to the left by 15 points, making the support of the people even more expensive than it was originally. Of course, while the general effect of both propaganda and coercion is likely asymmetrical, the precise degree to which the effect of the cause is different from its removal is an empirical question.

\subsection{3 - Conclusions}

Clearly, the two methods of obtaining popular support are not mutually exclusive. Increased provision of remunerative compensation by an insurgency can be combined with active preference manipulation to garner more popular support, with the aim being to obtain the needed quantity of popular support to be able to functionally challenge the state. And, indeed, in every specific case, the exact combination of methods that an insurgency uses to obtain popular support will vary. That being said, an insurgency will have a bounded amount of resources that it can apply to either the provision of remunerative compensation or the use of preference manipulation tactics. At the margin, a trade-off exists between the two, and, as will be developed in more detail in the next chapter, each insurgent organization will need to decide how many resources to allocate to each activity. The basic point is that a group cannot necessarily maintain a given level of, say, service provision and then just apply a significant amount of preference manipulation tactics in order to obtain their quantity of popular support demanded. An increase in one method may result in a decrease in the other method, assuming that the group is operating at the outer boundary of its so-called production possibility frontier. 
In sum, regardless of whether a group provides a lot of remunerative compensation and undertakes little preference manipulation tactics or vice-versa, the fundamental exchange relationship that is at the core of the mobilization process remains the same. Popular support needs to be purchased through some combination of service provision and the supply of material and ideational goods, coupled with preference manipulation strategies that employ some combination of the use of coercion against nonsupporters and propaganda extolling the insurgency and disparaging the regime.

\section{4 - What role does the state play in the population-insurgent group exchange relationship?}

In addition to the actions of the insurgency, both the political characteristics and behaviour of the state condition certain aspects of the exchange relationship by which an insurgent group obtains popular support. State characteristics and behaviour can either positively or negatively influence individual preferences towards supplying active and passive support to a rebel group. In this section, I argue that the mobilization context that is created by the state's policies and behaviour conditions the exchange relationship that is at the core of an insurgent group's efforts to achieve popular support in two ways. ${ }^{129}$ First, the political characteristics of the state that governs society can either positive or negatively affect the population's baseline preference for revolt, thereby influencing the costs that an insurgent group must pay to mobilize popular support. Secondly, the state's use of indiscriminate violence and repression influences the costs of participation or non-

\footnotetext{
${ }^{129}$ The mobilization context is very similar to the classical notion of a "political opportunity structure". The core difference is that the political opportunity structure illustrates how well a group is going to do politically, while the mobilization context speaks only to the idea of how easy it will be for an insurgent group to mobilize popular support. For a cogent review of the concept of the political opportunity structure, see Sidney Tarrow, Power in Movement: Social Movements, Collective Action, and Politics (Cambridge: Cambridge University Press, 1994).
} 
participation in collective action against the state, thereby affecting the amount of compensation individuals demand in exchange for providing support to an insurgent group at any given point and time.

\subsection{1 - The State's Political Exclusivity}

States that are fairly open to political participation, both during the course of daily politics and during potential peace negotiations, tend to decrease the population's underlying willingness to supply support to an insurgent group. ${ }^{130}$ Political participation is important to the population because it ensures the distribution of public goods and ensures the material needs and political satisfaction of the people. When groups are excluded from political participation, they tend to also be excluded from the material benefits and services that the state provides. In contrast, when groups are active in the political process, they tend to be able to secure some benefits for their constituency. As Jeff Goodwin notes, "Exclusionary regimes tend to 'incubate' radical collective-action: those who specialize in it tend to prosper, because they come to be viewed by many people as more realistic and potentially effective than political moderates, who themselves come to be viewed as hopelessly ineffective."131

\footnotetext{
${ }^{130}$ For a lucid discussion of this point see, for example, Jeff Goodwin, No Other Way Out: States and Revolutionary Movements, 1945-1991 (Cambridge: Cambridge University Press, 2001); David L. Horowitz, Ethnic Groups in Conflict (Berkeley: University of California Press, 2000). For a discussion of exclusive peace negotiations and the occurrence of insurgent violence by spoilers see Lisa Blaydes and Jennifer De Maio, "Spoiling the Peace? Peace Process Exclusivity and Political Violence in North-Central Africa," Civil Wars, Vol. 12, 1-2 (2010), 3-28.

131 Jeff Goodwin, "State-Centered Approaches to Social Revolutions: Strengths and Limitations of a Theoretical Tradition," John Foran ed., Theorizing Revolutions (London: Routledge, 1997), 18.
} 
Figure 2.3. The State's Exclusionary Politics and the Population's Preference for Rebellion

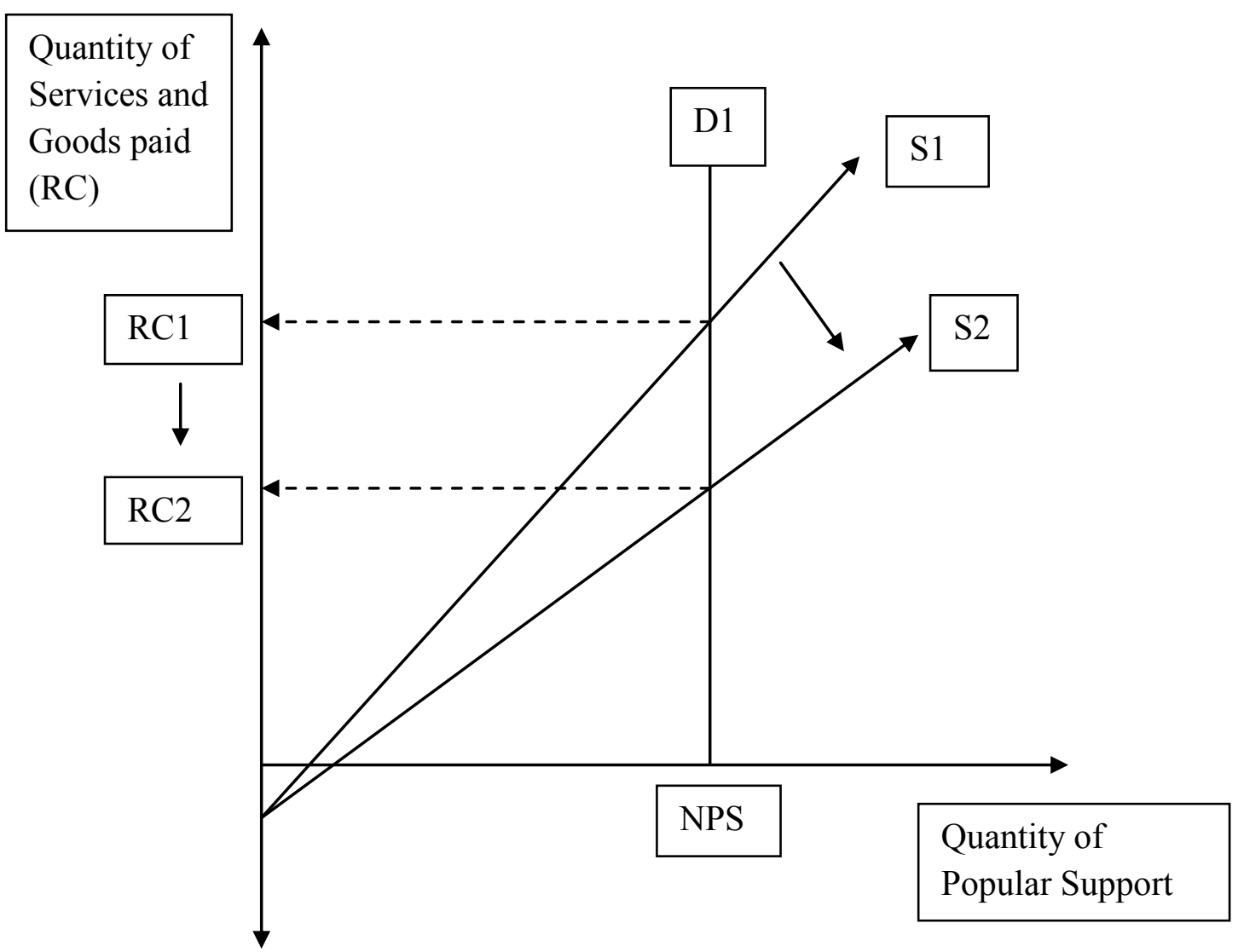

Both theoretical and empirical research, for example, has found that states with fairly accessible political processes, such as elections and fewer restrictions on free association, tend to inhibit a turn towards organized insurgency by allowing peaceful political engagement. In contrast, states that curtail peaceful political engagement and participation tend to give rise to more violent forms of political contestation. ${ }^{132}$ As Timothy Wickham-Crowley notes of the effect of an 'open' political system on the

\footnotetext{
${ }^{132}$ For the theoretical argument that suppression of peaceful protest can generate violent protest, see Mark Irving Lichbach, "Deterrence or Escalation? The Puzzle of Aggregate Studies of Repression and Dissent," Journal of Conflict Resolution, Vol. 31, no. 2 (1987), 266-297. For an empirical test of Lichbach's theory, see Will H. Moore, "Repression and Dissent: Substitution, Context, and Timing," American Journal of Political Science, Vol. 42, no. 3 (1998), 851-873.
} 
propensity towards revolt in Venezuela, "Political actors mostly attempted to secure government power through legal and electoral channels, and not by setting up a parallel government or counter-state as a path to dual power." ${ }^{133}$ In contrast, "the Cuban revolutionary movement of 1959 engendered cross-national opposition to the state largely because Felgencio Batista's regime was a personalistic [highly exclusive], rather than collective, form of dictatorship." ${ }^{134}$ During the CPP insurgency against the Marcos regime in the Philippines, one guerrilla retrospectively explained her motivation for joining the insurgency as a pure response to the regime's prohibition of peaceful political participation. "I didn't know what the underground was when martial law was declared. ... My going into the movement was totally because of martial law. It wasn't ideological. It was out of protest. I was not politically or ideologically prepared to go underground. But martial law left you with no choice."135 Likewise, after over a decade of relative calm in the Western Sahara, the Polisario Front turned once again to violent political action when it "was essentially excluded from peace negotiations over the future of Western Sahara." ${ }^{136}$ In Nepal, the Maoist insurgency was able to mobilize certain ethnic groups fairly easily because these segments society were "very poorly represented in the state apparatus, elected office or management positions," which generated considerable discontent and sympathy towards the insurgency. ${ }^{137}$ Open and accessible political

\footnotetext{
${ }^{133}$ Timothy Wickham-Crowley, Guerrillas \& Revolution in Latin America: a Comparative Study of Insurgents and Regimes Since 1956 (Princeton: Princeton University Press, 1993), 196.

${ }^{134}$ Mohammed M. Hafez and Quintan Wikorowicz, "Violence as Contention in the Egyptian Islamic Movement," Quintan Wiktorowicz ed., Islamic Activism: a Social Movement Theory Approach (Indianapolis: Indiana University Press, 2004), 66.

${ }^{135}$ Nelia Sancho, cited in, Gregg R. Jones, Red Revolution: Inside the Philippine Guerrilla Movement (Boulder: Westview Press, 1989), 108.

${ }^{136}$ Lisa Blaydes and Jennifer De Maio, "Spoiling the Peace? Peace Process Exclusivity and Political Violence in North-Central Africa," Civil Wars, Vol. 12, 1-2 (2010), 7.

${ }^{137}$ Gilles Boquerat, "Maoism and the Ethnic Factor in the Nepalese People's War," in Laurent Gayer and Christophe Jaffrelot eds., Armed Militias of South Asia: Fundamentalists, Maoists, and Separatists (New
} 
systems, therefore, tend to limit the extent and severity of an insurgency by reducing the population's preference for an alternative political system, while exclusive political regimes tend to increase the popular base of an insurgency and engender a turn to violence. ${ }^{138}$

Figure 2.3 show the effect that the state's political exclusivity has on the ease with which a rebel group can mobilize popular support. Imagine that you have two otherwise similar rebel groups faced off against otherwise similar states that vary only in their degree of political exclusivity. Each insurgent group need to mobilize NPS amount of popular support in order to challenge the state. One of the rebel groups is challenging an inclusive state that tries to accommodate itself to the needs and desires of the population. In this country, the population's preference for rebellion aggregates into the supply curve S1. The other rebel group is challenging a more exclusive state that bars, say, certain ethnic groups from meaningful participation in the politics of the nation. In this country, the preferences of the population for revolt aggregate into the flatter supply curve S2. Both groups need NPS amount of popular support in order to stand a chance of defeating the state. In the more inclusive country, the rebel group needs to provide $\mathrm{RC} 1$ amount of remunerative compensation to the population in order to secure enough popular support. In the more exclusive country, the rebel group can provide only RC2 amount of remunerative compensation and still secure enough popular support to effectively challenge the regime. The only change in these scenarios is the degree of political exclusion that the state exhibits.

York: Colombia University Press, 2009), 49; See also Prakash Adhikari and Steven Samford, "The Nepali State and Dynamics of the Maoist Insurgency," Studies in Comparative International Development, online first (2012), 8.

${ }^{138}$ Jeff Goodwin, "State-Centered Approaches to Social Revolutions: Strengths and Limitations of a Theoretical Tradition," John Foran, ed., Theorizing Revolutions (London: Routledge, 1997), 18. 
It is not uncommon for states to respond to an insurgent challenger through either increased democratization and political openness, as was done in British Malaya, or increased repression and political exclusion, as was done recently in Thailand. Changing political conditions are one way that a state can alter the political context that an insurgency must contend with. If a regime responded to an insurgency with increased political exclusion, the population's willingness to support the insurgency would likely increase and the insurgent group could then obtain more popular support in exchange for a given level of remunerative compensation. In the context of Figure 2.3, increased political exclusivity would alter the slope of the population's supply curve, moving it from, say, S1 to S2. A regime could also respond to an insurgent challenger by opening up its political system, thereby making the non-violent satisfaction of the people's political preferences easier. As the population's ability to achieve its political preferences within the current system increases, so does the general amount of remunerative compensation that it will demand in exchange for providing popular support to an insurgent group. Changes in a regime's political exclusivity will affect the course of the insurrection by influencing how cheaply the population will support an armed insurgency.

\subsection{2 - The State's Use of Indiscriminate Violence}

In addition to the basic political characteristics of the state, how the state behaves towards the population during the course of the conflict also affects the exchange relationship that ultimately determines how much popular support an insurgency receives. The state's use of discriminate or indiscriminate coercion, in particular, affects the population's calculations of the costs of supporting a revolt versus attempting to 
remain unaligned. Quite often, when faced with an active insurgent group, states respond with the vigourous application of coercion against identified guerrilla fighters, but also against both sympathizers and, at times, against the populace at large. The aim of discriminate coercion against insurgents is to decimate the ranks of the rebellion and reduce the extent of the challenge to the state's authority. A common problem with effectively implementing this tactic is that the collection of intelligence about individual insurgents is costly and generally a positive function of a state's control in a particular area. ${ }^{139}$ Given that, almost by definition, a state's control of some part of its territory has to be fairly low for an insurgency to emerge and persist for a reasonable amount of time, the state's ability to use wholly discriminate violence against an insurgency during most conflicts is generally restricted.

The main alternative to the use of discriminate violence against members of the insurgency is the use of more indiscriminate violence against the population. Nominally, the targeting of sympathizers and passive supporters would primarily occur, but, once again, the population holds private information about their actions, inactions, and disposition that are generally costly for the regime to learn, particularly in areas of weaker state control. As a result, the state's use of coercion often takes on a more wholly indiscriminate formation. Certainly, indiscriminate violence itself can be effective when the insurgency is primarily drawn from a proportionately small segment of the population, is confined to a small territorial area of the country, and can be even more

${ }^{139}$ Stathis Kalyvas, The Logic of Violence in Civil Wars (Cambridge: Cambridge University Press, 2009). 
effective than selective violence when the population that supports the insurgency has fairly inflexible preferences. ${ }^{140}$

From the perspective of rebel mobilization, the state's use of indiscriminate coercion is effectively an exogenous event that provides the population with potentially transient inducements towards more active and passive participation in an insurgency. ${ }^{141}$ Periods of state coercion can be more or less episodic, but the effect is similar, even while the extent of the effect would be highly variable. For a regime, the use of indiscriminate, or even just poorly targeted, coercion against the population can incentivise popular participation in the revolution. Indiscriminate coercion makes popular participation in insurgency more likely by increasing the costs of non-participation in an insurgency, while also making the cost of participating, both actively and passively, in armed revolt relatively less costly. ${ }^{142}$ The reason that state violence against the population can induce the population into supporting a rebel group is that an insurgency often provides security and protection from counterinsurgent violence to its supporters and membership. When the state employs indiscriminate violence, being a part of a rebellion is often one of the safer places to be. ${ }^{143}$

Comparative historical evidence bears out this tendency. During the Huk insurgency in the Philippines, for example, Jesus Lava, the leader of the Communist Party, noted that "the great majority of Huks," initially mobilized "because of repression

\footnotetext{
${ }^{140}$ Alexander B. Downes, "Draining the Sea by Filling the Graves: Investigating the Effectiveness of Indiscriminate Violence as a Counterinsurgency Strategy," Civil Wars, Vol. 9, no. 4 (2007), 420-444.

${ }^{141}$ T. David Mason and Dale A. Krane, "The Political Economy of Death-Squads: Toward a Theory of the Impact of State-Sanctioned Terror," International Studies Quarterly, Vol. 33, no. 2 (1989), 175-198.

${ }^{142}$ Stathis Kalyvas and Matthew Adam Kocher, "How 'Free' is Free-Riding in Civil Wars?: Violence, Insurgency, and the Collective Action Problem," World Politics, Vol. 59, no. 2 (2007), 177-216.

${ }^{143}$ The extent to which joining the rebellion versus other potential strategies, like trying to flee, is the most cost-efficient choice depends upon the rebel group's capacity. See, for example, Reed M. Wood, "Rebel Capability and Strategic Violence against Civilians," Journal of Peace Research, Vol. 47, no.5 (2010), 612.
} 
by the Philippine government, American soldiers, and civilian guards. Many felt it was either join or be killed without at least putting up a fight." ${ }^{144}$ Later, in the Philippines during the 1970s, "Martial law brought wholesale state repression and forced into the communist movement many young Filipinos who otherwise might never have joined." ${ }^{145}$ Similarly, in Guatemala, "Military repression of reformist efforts and community organization led ... to widespread defensive mobilization. ... Victimized by the military and lacking alternatives for economic self-improvement, the Indians became increasingly willing to turn to armed opposition, swelling the ranks of the guerrilla movement. By and large, their resistance was a result of state repression, not its cause." ${ }^{146}$ In Nepal, one individual from Jhapa noted, "When the state itself is engaged in indiscriminate killing and torturing innocent civilians, you either join the rebels or flee to a safer location." 147 During the FLN insurgency in Algeria, even as the initial organizational presence of the insurgency was heavily affected by counterinsurgent military activity, "there was a plentiful substitution of new recruits [for the insurgency] resulting from the indiscriminate mass arrests in the cities and overzealous ratissages [security sweeps] in the bled." ${ }^{148}$ Likewise, the PIRA in Ireland in the 1970s grew significantly as a result of extra-judicial and indiscriminate detention measures and the events of Bloody Sunday. As Paul D. Kenny notes, "The main consequence of these events was a massive increase

\footnotetext{
${ }^{144}$ Jose Lava, cited in, Jeff Goodwin, No Other Way Out: States and Revolutionary Movements, 1945-1991 (Cambridge: Cambridge University Press, 2003), 119.

${ }^{145}$ Gregg R. Jones, Red Revolution: Inside the Philippine Guerrilla Movement (Boulder: Westview Press, 1989), 61.

${ }^{146}$ Trudeau and Schoultz, cited in, Jeff Goodwin, No Other Way Out: States and Revolutionary Movements, 1945-1991 (Cambridge: Cambridge University Press, 2003), 166.

${ }^{147}$ Nepali interview respondent, cited in, Prakash Adhikari and Steven Samford, "The Nepali State and the Dynamics of the Maoist Insurgency," Studies in Comparative International Development, online first (2012), 10.

${ }^{148}$ Alisair Horne, A Savage War of Peace: Algeria, 1954-1962 (New York: New York Review of Books, 2006), 104.
} 
in the size of the PIRA. By 1973, the organization is estimated to have had as many as 3,000 members. ${ }^{149}$ In Afghanistan, senior Pakistani and American military officials have noted that, "The people believe that coalition forces are culturally insensitive, cause unnecessary civilian casualties, and fail to offer appropriate reparations for those casualties. The people then embrace badal [a part of Pashtunwali calling for revenge against affronts], increasing passive support for the Taliban and creating a pool of potential new fighters." ${ }^{150}$ During the Shining Path insurgency in Peru, the state's use of indiscriminate violence expanded the level of support for the insurgent group, which allowed it to "spread over a wider area and intensified" the conflict. ${ }^{151}$ In Kenya, one first-hand account of the growth of the Mau Mau insurgency in response to state repression is particular apt and worth quoting a length:

I learnt that Nyeri had 5,800 warriors in Nyandarua, of whom 1,800 were new recruits who had entered the forest within that week. The Government action of burning and evicting people all along the forest boundary, declining their farms to become 'Special Area' and forcing all men to become Home Guards and fight against their people in order to prove their loyalty to the Government made so many men flee to the forest in order to escape the Government punishment imposed to nonloyalists. This only increased our number in the forests; more fighters joined in this month than in any other. ${ }^{152}$

\footnotetext{
149 Paul D. Kenny, "Structural Integrity and Cohesion in Insurgent Organizations: Evidence from Protracted Conflicts in Ireland and Burma," International Studies Review, Vol. 12, no. 4 (2010), 544.

${ }^{150}$ Shahid Afsar, Chris Samples, and Thomas Wood, "The Taliban: An Organizational Analysis," Military Review (May-June 2008), 69.

${ }^{151}$ Lewis Taylor, Shining Path: Guerrilla Warfare in Peru's Northern Highlands, 1980-1997 (Liverpool: Liverpool University Press, 2006), 36.

152 Donald L. Barnett and Karari Njama, Mau Mau From Within: Autobiography and Analysis of Kenya's Peasant Revolt (New York: Modern Readers Paperback, 1966), 197.
} 
The state's use of indiscriminate violence shifts the population's supply curve to the right, as outlined in Figure 2.4. The implication of this shift is that the amount of remunerative compensation that an insurgency would need to pay in order to secure enough popular support to challenge the state decreases, falling from RC1 to RC2. The shift of the population's supply curve from S1 to S2 also means that a larger portion of the population, those people from origin to the intersection of S2 and the $\mathrm{x}$-axis, are now willing to supply both active and passive support to the insurgency without any remunerative compensation from the insurgency.

Figure 2.4. The State's Use of Indiscriminate Repression and the Preferences of the People

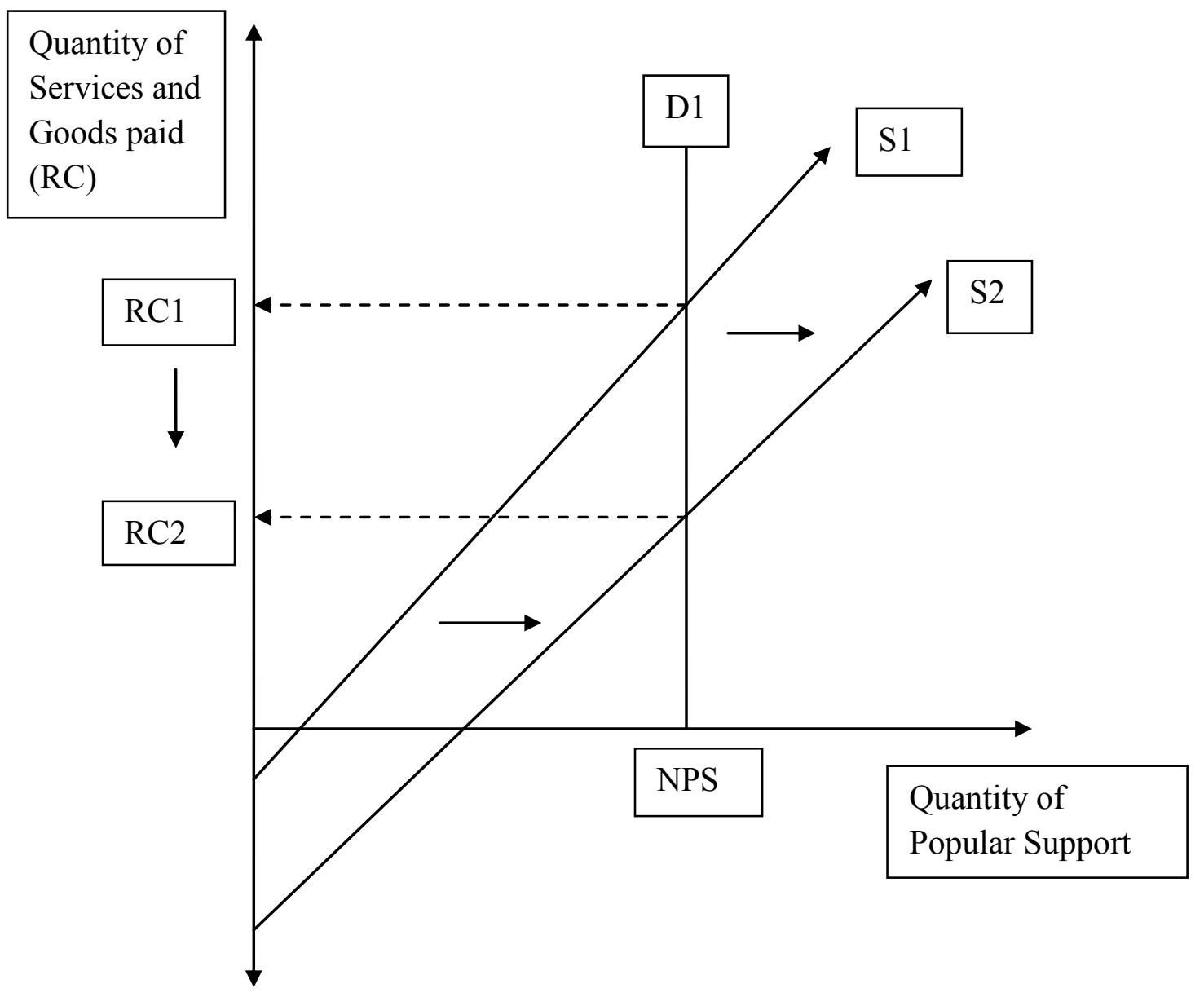


This intuition fits with Elizabeth Wood's finding that some people in the highly repressive context of the El Salvadorian civil war were willing to supply popular support to the insurgency without much direct compensation from the rebels. ${ }^{153}$ In other words, indiscriminate repression can destroy an insurgent organization, as happened in the 1980s during the Syrian regimes bombardment of Hama, but it also fosters popular support for rebellion. ${ }^{154}$ Often, as the evidence presented above suggests, the extent to which repression increases popular support for rebellion tends to outweigh the rate at which indiscriminate coercion can decimate a rebel group, although the relationship is likely parabolic with an exceedingly high level of repression leading to the destruction of a rebel group.

\section{5 - Conclusions}

In this chapter, I have argued that popular support for an insurgency comes in two forms: passive support and active support. Passive support for an insurgency involves favourable inaction on the part of the population. Most commonly, this action involves an unwillingness of the population to denounce members of the insurgency or provide information to the counterinsurgency on the general disposition, location or organizational structure of the rebel group. Passive popular support indirectly augments the capacity of the insurgency relative to the state by decreasing the efficacy of counterinsurgent military activity due to a lack of actionable information about the insurgency. Active popular support for an insurgent group, in turn, involves the

\footnotetext{
${ }^{153}$ Elisabeth Jean Wood, Insurgent Collective Action and Civil War in El Salvador (New York: Cambridge University Press, 2003).

${ }^{154}$ See, Martin Van Creveld, The Changing Face of War: Combat from the Marne to Iraq (New York: Ballantine Books, 2008), 235-246.
} 
population's overt participation and contribution to an insurgency. Such support directly augments the insurgency's capacity relative to the forces of the counterinsurgency.

Given that providing support to an insurgency can be costly to the individual, the people are unlikely to provide support without compensation, unless they strongly prefer the insurgency over the counterinsurgency and current regime. ${ }^{155}$ Thus, I presented a market exchange theory of how an insurgent group obtains popular support. In this theory, an insurgency has two ways of obtaining popular support. A rebel group can either supply a bundle of payment, inclusive of both services and goods, to the population or it can influence the population's preferences through the use of coercion and propaganda. Together, the provided bundle of services and goods compensates a population in exchange for their support of a rebel group, while the threat of coercion raises the costs of non-compliance with insurgent demands and propaganda persuades people that support of a rebellion is a good cause. Insurgent organizations, then, can obtain popular support by manipulating both the supply of positive benefits and the population's preference for insurgency.

Crucially, the quantity of popular support that an insurgency demands is determined by the strength of the state and the price and availability of capacity augmenting substitutes. The amount of popular support that an insurgency demands, therefore, is disconnected from the actual ability of an insurgent group to produce enough remunerative compensation and preference manipulation tactics to obtain the amount of popular support that they require in order to effectively challenge the regime. Put otherwise, an insurgency might not be able to obtain its needed quantity of popular

\footnotetext{
${ }^{155}$ For the original formulation of the collective action problem see Mancur Olsen, The Logic of Collective Action: Public Goods and the Theory of Groups (Cambridge: Harvard University Press, 1971).
} 
support and so will remain weak relative to the state. As a result, an insurgent group has an incentive to increase its supply of remunerative compensation and/or its application of preference manipulation tactics until it can obtain its quantity of popular support demanded - that is, until it can achieve enough popular support to functionally challenge the regime politically and militarily. The presence of this incentive begs the obvious question that is answered in Chapter 3: how does an insurgent group increase its supply of remunerative compensation and its ability to apply preference manipulation tactics? 


\section{Chapter 3: The Structural Characteristics of Insurgent Groups and Organizational Growth}

In the previous chapter, I developed an exchange theory that explains how insurgent groups obtain popular support. I argued that a rebel group can obtain popular support through two non-exclusive methods. First, a rebellion can provide the population with remunerative compensation, thereby satisfying the population's preference for recompense in exchange for support. Secondly, an insurgency can use preference manipulation tactics in order to alter the population's willingness to supply popular support to an insurgency at any given 'price'. The population's willingness to provide support to an insurgency, that is, the price the insurgency has to pay to obtain a given level of support, is conditioned by the state's degree of political exclusivity and its use of indiscriminate violence, with more exclusive and more repressive regimes encouraging the population to support an insurgency at a cheaper price. The amount of popular support that an insurgency demands (put otherwise, the amount of support the group needs in order to effectively challenge the regime) is conditioned by the strength of the state that the insurgency is challenging and the price of substitutes to popular support, such as external support or illicit crops and lootable natural resources.

A largely unexplored intuition follows from the exchange theory of insurgent group mobilization and popular support. Since an insurgency's needed amount of popular support is set relative to its opponent's capacity and the price of alternative sources of support for the insurgency, the quantity of popular support that an rebel group demands might have little relationship to a group's actual ability to obtain that support through a process of exchange. Thus, the derivative intuition is this: unlike the outcome of an 
exchange relationship in a perfectly competitive market, an insurgent group's demand for popular support might go unsatisfied - at least initially. The potentially severe disconnection between the needed amount of popular support and the amount of support that an insurgency is actually able to obtain raises three questions that are addressed in this chapter.

1. How can an insurgent group grow in size so as to bridge the gap between its current amount of mobilized popular support and the quantity of popular support that it needs to effectively challenge the regime?

2. How can an insurgency produce enough popular support-securing outputs to obtain growth?

3. What rebel group organizational structure leads to the highest growth potential? In this chapter, I argue that an insurgent group that is currently not expanding in size can obtain organizational growth if its incoming level of popular support (revenue) is greater than its outgoing expenditures (costs). More precisely, I argue that an insurgency can shift from a position of stasis or decline to one of organizational growth by expanding its administrative presence and centralizing its organizational structure, which alternatively imbue the group with economies of scale and increase the group's efficiency.

Before proceeding, a final word on the focus of the chapter is needed. In this chapter, I ask, broadly speaking, how an insurgent group can best structure itself so as to obtain organizational growth by mobilizing more popular support over time. Some key considerations are left for the next chapter. Of particular note is that I do not consider how the characteristics that enhance a rebel group's ability to obtain growth might either 
positively or negatively affect the insurgency's overall military position relative to the state that is trying to eradicate it. This exclusive focus on an insurgent group's mobilization of the population is a conscious choice. The next chapter deals with the contending incentives that a rebel group faces when the analytical focus is placed on the strategic interaction between the regime and the insurgency.

\section{1 - How can an insurgent group grow in size so as to bridge the gap between its current amount of mobilized popular support and the quantity of popular support that it needs to effectively challenge the regime?}

In this section, I present a basic profit margin model to specify the conditions under which an insurgency is able to obtain organizational growth over time. In its simplest formulation, and leaving aside the effect of attrition of rebel forces for the moment, an insurgency can grow over time if the cost of producing a bundle of popular supportsecuring outputs is less than the amount of popular support (capacity augmenting inputs, as advanced in chapter 2) that the rebellion receives in exchange from the population.

Insurgent groups that use an exchange relationship to obtain popular support are involved in an inherently dynamic process. Insurgents expend resources to produce some amount of popular support-securing outputs. Providing the population with popular support-securing outputs results in the support of the people to some degree. This support manifests as capacity augmenting inputs that an insurgency can then expend, at some future date, on both military (fighting the regime) and political (producing more popular support-securing outputs) activity. Leaving aside the effect of attrition on rebel group growth for the moment, an insurgent group needs to be expending fewer resources to produce a bundle of popular support-securing outputs than it receives in return from the 
population in order to ensure organizational growth over time. In a rough, yet nevertheless apt, comparison to a firm, an insurgent group needs to generate a profit, where the resources expended in production are less than the resources obtained in exchange, in order to grow in size over time. Since no insurgent group is likely to start a conflict with enough capacity to effectively challenge the state, all rebellions need to be concerned with organizational growth. In most cases, this primary concern implies that an insurgency also needs to be mindful, to some extent at least, of how to organize so as to maximize both production capacity and efficiency, given the overarching environment that the group exists within.

Two sets of factors coalesce to determine if a rebel group is growing in size, shrinking, or simply staying the same size over time: the population's willingness to supply support to an insurgency and the internal group structure of the insurgency. ${ }^{156}$ The population's willingness to support an insurgency structures how much revenue the insurgency brings in in exchange for its provision of popular support-securing outputs. More favourable populations are willing to provide more revenue to an insurgency in exchange for a given level of compensation than less favourable populations.

As pointed out in chapter 2, the two primary variables that structure the population's preference for revolt are 1) the political exclusivity of the state and 2) the state's use of indiscriminate repression. The more politically exclusive a state is, the more willing the population likely is to support an alternative political arrangement, which is presumably offered by the insurgency. The more the state uses indiscriminate repression, the more the population is likely to try and protect itself from the state's excesses by

\footnotetext{
${ }^{156}$ For a similar idea that terrorist groups structure themselves in response to internal and external factors, see Joshua Kilberg, "A Basic Model Explaining Terrorist Group Organizational Structure," Studies in Conflict and Terrorism, Vol. 35, no. 11 (2012), 810-830.
} 
joining the rebellion ${ }^{157}$ and the more likely it is that people will find "pleasure in the agency" of supporting an insurgency. ${ }^{158}$ Both of these factors make it easier for an insurgent group to mobilize popular support because it makes support effectively cheaper to purchase through a process of exchange. In this sense, the preferences of the population matter a great deal for an insurgency, as they determine part of the equation that specifies how quickly the rebel group will grow and how big the rebellion is likely to become.

The other set of factors that determine if a group is growing are internal to a rebel movement and involve the group structure of the insurgency. This group structure has two components: the group's administrative presence and the group's degree of organizational centralization. The scale of a rebel group's administrative presence affects its total production capacity and essentially determines the amount of output that it can produce, which can, in turn, lead to economies of scale. Organizational centralization affects a group's ability to obtain efficient, as in cost effective, production.

\footnotetext{
${ }^{157}$ Stathis N. Kalyvas and Matthew Adam Kocher, "How 'Free' is Free Riding in Civil Wars? Violence, Insurgency, and the Collective Action Problem," World Politics, Vol. 59, no. 2 (2007), 177-216.

${ }^{158}$ Elisabeth Jean Wood, Insurgent Collective Action and Civil War in EI Salvador (New York: Cambridge University Press, 2003).
} 
Figure 3.1. Insurgent Group Mobilization Context, Group Structure, and Organizational Growth or Decline

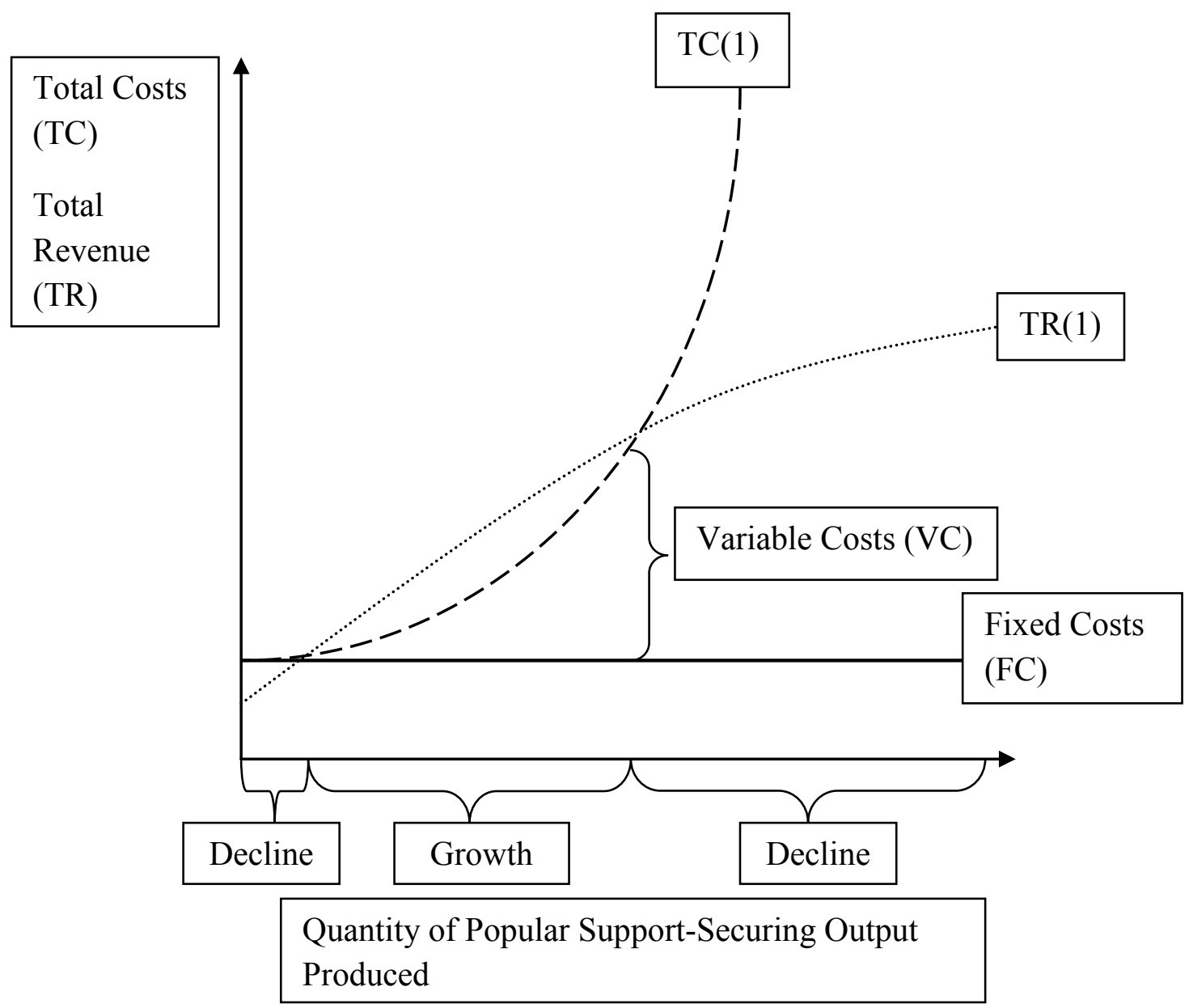

Figure 3.1 systematizes into a simplified conceptual model the basic idea that organizational growth is related to an insurgency's incoming revenue and outgoing costs. In this figure, the TR curve represents total revenue, the FC curve represents fixed costs, the TC curve represents total costs, and VC are the variable costs. A rebel group's production of popular support-securing output is measured on the $\mathrm{x}$-axis and both total costs and total revenue are measured on the y-axis, which implies they are measured in 
like units (say, dollars). The interaction of all of these variables determines whether or not an insurgent group is growing, shrinking, or remaining the same size over time. I deal with each in turn.

Total revenue represents the amount of popular support an insurgent group obtains from providing the population with remunerative compensation and after it has used its preference manipulation tactics. The curve is nonlinear because the benefits that the population provides in exchange for remunerative compensation and the rebel group's use of preference manipulation tactics tend to decrease as the total quantity supplied increases. People will willingly supply a large amount of benefits if the insurgency operates a hospital in an area. If the insurgency were to start up a second hospital in the same area, the amount of support that the people will provide would not be twice as much as before. Instead, the people might provide more absolute support than before, but less than a full one hundred percent increase. The same diminishing marginal returns would obtain for propaganda, coercion, wages and every other form of inducement or tactic that an insurgency can use to obtain the support of the population.

Both the slope and the intercept of the total revenue curve are determined by a population's preference for revolt. In Figure 3.1, the total revenue curve starts a part of the way up the total revenue axis. This intercept entails, as also shown in the models in Chapter 2, that there is a small core to the population that provides popular support (revenue) to an insurgency without the rebellion needing to compensate them through the normal processes of exchange. The intercept can be further affected by the regime's behaviour. Under regimes that exhibit a high level of indiscriminate repression, the people often, as outlined in chapter 2, provide support to the insurgency without 
demanding any real compensation in exchange, although the desire to support an insurgency in the face of repression usually requires an insurgency that can offer some semblance of protection to its membership and supporters. Higher levels of indiscriminate state repression, therefore, raise the intercept of the total revenue curve, meaning the rebel group is more likely to generate a profit and to grow in size over time.

The slope of the total revenue curve varies according to the political exclusivity of the regime. States that are more politically exclusive result in a steeper slope, where the people are willing to provide a lot of popular support to an insurgent group in exchange for relatively little popular support-securing outputs. More politically inclusive states generate a worse mobilization context for an insurgency, meaning the total revenue curve is flatter. In this case, for a given level of total production costs, more popular supportsecuring outputs would need to be produced in order for an insurgency to obtain a given unit of popular support. Overall, the total revenue (popular support) that an insurgency can obtain in exchange for a give quantity of popular support-securing outputs is greater when the rebel group's mobilization context is more favourable. More revenue, in turn, increases the chances that an insurgency can grow over time.

In general terms, the costs of producing popular support-securing outputs come in three forms: variable, fixed and total. I discuss each type of cost in general terms in this section and provide more detail about how costs can be mitigated or managed through an expansion of a rebel group's administrative presence and through organizational centralization in the next two sections. Variable costs are the costs that accrue with the production of an additional unit of popular support-securing output. Variable costs are composed of both the cost of the raw materials (labour and capital) that go into producing 
a unit of output and the cost of the production process itself, which can be more or less efficient. Variable costs can either be constant, as in each unit of output costs the same as every other, or truly variable, in the sense that additional units of output can cost less or more than previous units. As it is depicted in Figure 3.1, variable costs are variable over the quantity of popular support-securing outputs produced, so each unit of output costs more to produce than each previous unit and less than each future unit. Variable costs increase at an increasing rate because labour, capital, and other production materials come into short supply and quality, which makes the final unit of output produced infinitely expensive.

Fixed costs are the costs that a rebel group must pay in order to maintain its productive organization and administrative presence. Fixed costs can never be reduced to zero so long as a rebel group exists. A rebel group cannot produce any output without maintaining some sort of organization and some form of administrative presence, although, as I detail in the next two sections, the amount of fixed costs that an insurgency needs to pay vary in predictable ways. The fixed cost curve is horizontal because fixed costs do not shift based upon the amount of output that is produced. Rebel groups need some guerrillas in place to administer justice in an area if they are going to supply the people with remunerative compensation. These guerrillas will cost some amount of money to maintain even if they do not undertake their designated task. This cost is the fixed cost of having an organizational and administrative presence.

Total costs are the sum of an insurgency's fixed costs plus its variable costs. The total cost curve intersects the y-axis at the same point as the fixed cost curve. Total costs start at the level of fixed costs for the simple reason that the cost of producing no output, 
at least while still maintaining the organization and administrative presence to do so in the future, means that the insurgency needs to pay all the fixed costs up front. Total costs then increase as the quantity of output that a rebel group produces goes up, since the insurgency needs to pay the additional variable costs for each unit of popular supportsecuring output that it produces.

An insurgency is breaking even when the total revenue curve, TR, intersects with the total cost curve, TC. When the total revenue curve is above the total cost curve, the insurgency is growing in size, as the amount of capacity being obtained from the people is greater than the amount being spent to produce popular support-securing outputs. The point at which the total revenue and the total cost curves are tangent is the most efficient production point, where marginal costs are equal to marginal benefit, while the intersection of the total revenue curve and the total cost curve at the far right hand side of the growth range results in the largest organizational size.

\section{2 - How can an insurgency produce enough popular support-securing outputs to obtain growth?}

In this section, I argue that as a rebel group's administrative presence increases in scale, two countervailing effects result. First, a larger scale administrative presence increases the rebel group's fixed costs, which in turn increases the total costs that the insurgency needs to absorb in order to obtain growth. Second, as the scale of an insurgent group's administrative presence increases in scale, the rebellion's production capacity rises, which allows the insurgency to produce more popular support-securing outputs. If production rises to a sufficient degree, an insurgency can produce itself into growth. 
Below, I first outline how I conceptualize two core concepts: economies of scale and rebel group administrative presence. I then specify, using a modified version of the profit margin model introduced in the last section, why an insurgent group may need to invest in expanding its administrative presence in order to increase the quantity of output that it can generate in any given period. Such an investment, while increasing the fixed costs that the group needs to pay, can actually allow the insurgency to obtain organizational growth. I argue further than an insurgency can expand its administrative presence through two non-exclusive ways: via the incorporation of pre-existing sociopolitical networks or through original organization building. Which method of expansion is adopted affects the group's fixed costs and so the ability of an insurgency to obtain growth. Throughout the analysis, I shore up my argument with historical examples, although the particular mechanisms at work in this case are extremely hard to observe directly.

\subsection{1 - Defining Economies of Scale and Insurgent Group Administrative Presence}

Economies of scale emerge when the scale - as in size - of a firm's (or a rebel group's) production capacity increases. Michael Todaro defines economies of scale as, "Economies of growth resulting from expansion of the scale of production capacity of a firm or industry, leading to increases in its output and decreases in its costs of production per unit of output."159

A simple numerical example should help to clarify the concept of economies of scale as it applies in this context. An insurgency's production of health services, for instance, comes with a certain fixed cost needed to train medical staff and administrators,

${ }^{159}$ See Michael P. Todaro and Stephen C. Smith, Economic Development 10th ed., (2009), 821. 
establish facilities, and develop the infrastructure to deliver medical services to the population. These initial fixed costs, plus the additional costs for antibiotics, gauze, and other useable medical supplies, make the average cost of a small quantity of output quite high. Say that the fixed costs of setting up medical services was 1,000 dollars and that the additional variable cost per unit of output was 1 dollar. If the insurgency produces 10 units of medical services, the average cost per unit would be 101 dollars. Imagine instead that the insurgency produced 100 units of health services. The average cost would now be 10.10 dollars per unit. If the quantity produced increased to 1,000 units, the average costs per unit would fall to 1.01 dollars, and so forth. In sum, once the initial fixed costs have been absorbed by an organization, and assuming that variable costs remain constant as output rises (not captured in the figure), the average cost per unit of output declines as the quantity produced rises.

I conceptualize rebel group administrative presence as the scale of insurgent productive infrastructure and organization in a given area. Insurgent infrastructure and organization are a rebel group's equivalent (sometimes literally so) of a firm's factories, facilities, management offices, and supply chains. An insurgency cannot produce any sizeable quantity of popular support-securing outputs if it lacks some minimal administrative presence in an area. As the scale of an insurgency's administrative presence rises, its capacity to produce remunerative compensation and preference manipulation tactics should also rise. The overall scale of an insurgency's administrative presence is actually a composite of its administrative depth and its administrative breadth. Administrative depth is an expression of the thickness of an insurgent group's 
Figure 3.2. An Insurgency's Investment in Administrative Presence and Group Growth



administrative infrastructure and organization in a given area. Administrative breadth is the reach of an insurgency's infrastructure and organization across a territory.

\subsection{2 - An Expanded Profit Margin Model: Rebel Group Administrative Presence and Quantity Produced}

Rebel groups do not start out with the ability to produce popular support-securing outputs like food, justice administration, security provision, propaganda messages or coercion in unlimited quantities. In any given area, the quantity of popular support-securing outputs that a rebel group can produce is dependent upon the scale of its administrative presence, 
which is akin to a firm's productive infrastructure. A small scale administrative presence can produce some output, but the costs of producing more output rapidly increase as the production level overwhelms the rebellion's available production capacity. To correct for this problem, a rebel group can invest in the expansion of its administrative presence to effectively expand its production capacity and market access. However, while a larger administrative presence increases an insurgency's production capacity, it also costs resources to develop and maintain. The bottom line is that an insurgent group can invest resources to expand the scale of its administrative presence so as to increase its production potential, but such an investment also raises the group's fixed costs. If output production is increased to a large enough extent, economies of scale can emerge as the group distributes its fixed costs across more units of output. A sufficiently large increase in output production allow a group that was previously not able to grow large enough to effectively challenge the state to mobilize sufficient popular support to do so.

Figure 3.2 depicts the relationship between an expansion of an insurgent group's administrative presence and the insurgency's ability to secure growth. In this example, an insurgent group has a fixed total revenue curve, TR(1), which represents the aggregate of the entire population's willingness to supply popular support to the insurgency in exchange for popular support-securing outputs. Say the rebel group starts out, as all groups inevitably must, with a small administrative presence which generates a total cost curve TC(1). Along this cost curve, a rebel group can produce around a maximum of Q1 amount of output before the costs of producing more remunerative compensation and preference manipulation tactics escalate exponentially and quickly outweigh the benefits 
that the group obtains in exchange. Costs escalate so rapidly because the available production infrastructure simply becomes overwhelmed, and, for a given level of productive efficiency, no more output can be realistically squeeze out. Imagine that there are four insurgents working in a village and that they are tasked with providing up to Q1 amount of remunerative compensation and preference manipulation tactics. These four individuals are, say, working 24 hours a day to the best of their ability (really costs would start to escalate to prohibitive levels well before this point). With these four insurgents working this hard, additional output beyond Q1 cannot be obtained without impossibly high costs. If, in exchange for Q1 amount of popular support-securing outputs, the rebel group is not obtaining enough popular support to effectively challenge the regime, then it needs to produce more in order to bring more of the people on side.

Now, recognizing this problematic situation, a rebel group could invest in expanding the scale of its administrative presence. It could increase its depth in an area by adding additional layers to its administrative presence in a given village, city, or region. Such a move would, for example, add a fifth guerrilla to our previous team of four. Alternatively, it could invest in expanding its presence to a new village, which would expand its administrative breadth. In either case, the rebel group has to bear an additional fixed cost in addition to $\mathrm{FC}(1)$ in order to establish this new organization. This effect is captured by the higher intercept of each subsequent total cost curve when compared to the one previous. The increase in fixed costs for every expansive move are not likely to be constant, as some elements, like a leadership core, might not need to be replicated at every turn. Since fixed costs often decline as the group expands, larger 
scaled production drives down the average cost per unit of output and makes obtaining organizational growth easier.

Overall, the important point to note in Figure 3.2 is that an investment in the expansion of a rebel group's administrative presence raises the group's fixed costs, but also increases the amount of capacity that the insurgency can produce while still generating a profit. In the figure, the initial rebel group might be producing at a maximum of Q1 along TC(1), but, so long as its accrued wealth can cover the fixed costs of expansion, the group can expand. It can continue doing so until its production reaches, say, Q4 along TC(4), at which point we could say that it has mobilized enough capacity to effectively challenge the regime. As it is depicted, if the group needed to expand further, it could do so via the same process. In the next two sections, I unpack the notions of rebel expansion and the generation of economies of scale that I have pointed to in a preliminary and more abstract way in this section.

\subsection{3 - Marginal Tradeoffs: Military Versus Administrative and Depth Versus Breadth}

Given that every insurgency has a finite amount of resources and group capacity at any single point and time, there is a two-stage sorting process at work that determines the absolute size of a rebel group's administrative presence. In the first sorting stage, the insurgency needs to decide how many resources and how much group capacity it will devote to strictly military activity and how much it will devote to administration, the latter largely involving the production of popular support-securing outputs. Admittedly, some effects of military activity, such as harassing state forces, can result in increased security for the population in insurgent-controlled areas, meaning that the military activity is, in some ways, a more or less far-flung version of remunerative compensation 
provision. Regardless, at the margin, a rebel group needs to make an initial trade-off between its military and its administrative tasks.

Historical evidence suggests that, both across groups and within a single group across time, the relative allocation of resources toward administrative activity versus military tasks is highly variable. Hezbollah, for example, devotes a significant proportion of its resources toward building up its administrative apparatus in the Beirut suburbs and Southern Lebanon. ${ }^{160}$ In contrast, the LTTE often devoted a greater relative share of its resources to military operations, such as building the naval Sea Tigers, which meant that it had less capacity to expend on deepening and broadening its administrative presence. ${ }^{161}$ Likewise, over the course of time, the same rebel group can change its relative allocation of resources from administrative to military tasks and back again depending upon the overall needs of its campaign. In Eritrea, for instance, a massive Ethiopian offensive by Derg forces in 1978 caused the EPLF to withdrawal from many towns and villages. Consequently, for the insurgency "organizing [the people] was subordinated to the military fight-back, and many of the personnel involved in mass administration returned to military duties." ${ }^{162}$ Near to the end of the conflict, as the military situation shifted back again in favour of the EPLF, the relative balance of administrative activity and military tasked shifted back again towards a heavier emphasis on administration. By the end of the war, over 80 percent of villages in Eritrea had an insurgent administrative committee

\footnotetext{
${ }^{160}$ Stefan Malthaner, Mobilizing the Faithful: Militant Islamist Groups and Their Constituencies (New York: Campus Verlag, 2011), 174-231.

${ }^{161}$ Shawn Teresa Flanigan, "Nonprofit Service Provision by Insurgent Organizations: The Cases of Hizballah and the Tamil Tigers" Studies in Conflict and Terrorism, Vol. 31, no. 6 (2008), 509.

${ }^{162}$ David Pool, From Guerrillas to Government: The Eritrean People's Liberation Front (Athens: Ohio University Press, 2001), 118-119.
} 
of varying depth. ${ }^{163}$ Unsurprisingly, rebel groups under a significant amount of military pressure tend to devote more resources to military activity and relatively less to administrative tasks and to mobilizing the population.

Within the quantity of resources and capacity that is devoted to administrative tasks, a second trade-off exists between increasing the depth of the rebel group's administrative presence in one area versus expanding the group's administrative presence across larger areas. Both movements increase the scale of the insurgency's administrative presence within a territorial area, but clearly do so in different ways. Depth increases the concentration of insurgent administration, while breadth expands its scope. Insurgent groups vary in terms of whether increased breadth or increased depth presents the best course of action.

Numerous historical examples highlight the trade-off that rebel groups face between increasing the depth and expanding the breadth of their administrative presence. These examples also plausibly show how different insurgent group's aim to maximize their return to increased administrative presence - assuming, of course, that rebel groups do learn and do attempt to maximize their returns. Hezbollah, for example, has developed a very deep administrative presence in the suburbs of Beirut and Southern Lebanon, while, in contrast, it has spent very few resources attempting to expand the breadth of its administrative presence beyond predominantly Shi'a populated area. ${ }^{164}$ The Vietcong devoted significant resources to expanding its administrative presence across large swaths of South Vietnam, while also building up some areas of considerable

\footnotetext{
${ }^{163}$ Dan Connell, Against All Odds: A Chronicle of the Eritrean Revolution (Lawrenceville: Red Sea Press, 1997), 237.

${ }^{164}$ Stefan Malthaner, Mobilizing the Faithful: Militant Islamist Groups and Their Constituencies (New York: Campus Verlag, 2011), 174-231.
} 
administrative depth. ${ }^{165}$ Recognizing a lack of sufficient returns to a relatively dense administrative presence in a single area, the Huk rebellion in the Philippines attempted to expand their administrative presence outside of Central Luzon by increasing the breadth of the insurgency's administration, although it failed to do so due to weak organizational monitoring and control mechanisms. ${ }^{166}$ Having spread to all of Peru's twenty four departments by the mid-1980s, the Shining Path would establish a village-level administrative presence that put an area under "the control of five individuals who [were] responsible for the administration of most aspects of the community's routine. Apart from the group leader, these [insurgent administrators] are in charge of security, educational development, production, party organization, and recruitment." ${ }^{167}$ In other words, the Shining Path's administrative presence spread broadly, but often lacked considerable depth at the village-level, as I point out in more detail in chapter 6 .

In sum, all insurgent groups face two trade-offs when allocating their finite resources and capacity to increasing the scale of its administrative presence. First, an insurgency faces a marginal trade-off between increasing its military tasks versus increasing its administrative presence. Secondly, there is a second marginal trade-off that exists between increasing the depth versus increasing the breadth of a rebel group's administrative presence.

\subsection{4 - Expanding Administration and the Generation of Economies of Scale}

\footnotetext{
${ }^{165}$ Douglas Pike, The Vietcong: The Organization and Techniques of the National Liberation Front of South Vietnam (Cambridge: MIT University Press, 1968).

${ }^{166}$ Benedict J. Kerkvliet, The Huk Rebellion: a Study of Peasant Revolt in the Philippines (New York: Rowman \& Littlefield Publishers, Inc., 2002), 235.

${ }^{167}$ Gordan H. McCormick, The Shining Path and the Future of Peru (Santa Monica: RAND Corporation, 1990), 19.
} 
In this sub-section, I show that there is a continuum of methods that a rebel group can use to expand its administrative presence. At one end of the continuum, an insurgency can build its administrative presence from scratch, without relying on any pre-existing sociopolitical groups. At the other end of the continuum, a rebel group can expand by incorporating pre-existing socio-political networks into its overarching administrative structure. Most actual rebel groups probably increase their administrative presence through some combination of both methods. I also detail how economies of scale emerge as an insurgency's administrative presence expands and how this can result in a lower average cost per unit of output. Finally, I outline how the method that an insurgent group uses to expand its administrative expansion affects the average cost per unit of popular support-securing output that the group produces, with groups that expand via incorporation and assimilation generally obtaining lower long run average costs than groups that expand through wholly-original organizational building.

\subsection{5 - Expansion Via Wholly-Original Organization Building}

An insurgent group can expand its administrative presence through original organization building. In its most extreme form, this method of expansion requires that an insurgency construct from scratch every part of its organization, infrastructure, and administration as it expands outwards over territory or downwards into the sociological roots of a population within a given area. Organizational building of this sort entails that the rebel group needs to pay certain fixed costs as its administrative presence expands. However, as its administrative presence grows, its productive capacity increases and the quantity of remunerative compensation and preference manipulation tactics that it produces should rise accordingly. As the quantity of output rises, economies of scale emerge as the fixed 
costs of administrative building are spread out across a higher quantity of outputs. Thus, as the quantity of output rises in step with the horizontal or vertical expansion of an insurgency's administrative presence, the average cost per unit of output should fall. As the average cost per unit of output falls, the chance that the group can secure positive organizational growth is enhanced. The core expectation that follows from this notion is that as an insurgency's administrative presence expands either broadly across an area or deeper into the sociological bases of a given area, output should rise and the extent of popular support that the group obtains should rise as well.

A significant amount of historical evidence suggests that as an insurgency's administration expands, so does its ability to mobilise the population, which is in line with the theoretical expectations. While the historical evidence is not necessarily definitive of the emergence of economies of scale in production, it remains highly plausible that economies of scale likely do in fact emerge as an insurgency's administrative presence expands and that this provides a core motivation for a rebellion's decision to increase its administrative presence across areas or through increased depth. David Pool notes, for example, that for the EPLF in Eritrea, "The greater the presence [of insurgent administration], the greater the capacity to recruit from highlanders." ${ }^{168}$

Likewise, Eqbal Ahmad argues in more general terms that:

The rebels must build an administrative structure to collect taxes, to provide some education and social welfare, and to maintain a modicum of economic activity. A revolutionary guerrilla movement which does not have these administrative concerns and structures to fulfill its obligations to the populace

\footnotetext{
${ }^{168}$ David Pool, From Guerrillas to Government: The Eritrean People's Liberation Front (Athens: Ohio University Press, 2001), 107.
} 
would degenerate into banditry. Even in clandestiness, the parallel government must prove its efficacy. ${ }^{169}$

Indeed, in Vietnam, where the localized military balance allowed the Vietcong to fully develop its administrative presence, insurgent mobilization of the population was at its highest level, with the sheer scope of the mobilization being suggestive of the idea that economies of scale were contributing to the amount of popular support-securing outputs that were being created. As one study drawing on interviews with over 2,400 Vietnamese villagers notes, "In their [Viet Cong] villages, ... everybody worked for the [National Liberation] Front. Those who were not in some kind of military service were tapped for labor [sic] service, and those who were too old or weak to perform labor [sic] services were assigned some other kind of duty. This high degree of mobilization was made possible by the Viet Cong organizations [administrative presence, in my conceptualization], which embraced nearly everybody." ${ }^{170}$

A markedly similar pattern is present in other insurgencies, ranging from the Middle East to Africa. Hezbollah, for example, operates primarily in southern Lebanon, the Beirut suburbs, and the Beqaa Valley. After years of organizational development, the insurgency has achieved a high level of popular support among the Shi'a population through the provision of services, goods, and the use of propaganda and the threat of sanction for non-compliance. ${ }^{171}$ In order to produce these popular support-securing outputs at an efficient level, Hezbollah has had to develop an administrative presence of

\footnotetext{
${ }^{169}$ Eqbal Ahmad, "Revolutionary Warfare and Counterinsurgency," in Gerard Chaliand ed., Guerrilla Strategies: An Historical Anthology from the Long March to Afghanistan (Berkeley: University of Californian Press, 1982), 249.

${ }^{170}$ W.P. Davison, "Some Observations on Viet Cong Operations in the Villages," RAND Research Memorandum, RM-5267/2-ISA/ARPA (July 1967), 77.

${ }^{171}$ Shawn Teresa Flanigan, "Nonprofit Service Provision by Insurgent Organizations: The Case of Hizballah and the Tamil Tigers," Studies in Conflict and Terrorism, Vol. 31, no. 6 (2008), 499-519.
} 
significant depth in its areas of control. For instance, Al-Shaid delivers financial assistance to the families of 'martyrs,' while Al Jahar provides material and educational assistance to wounded fighters. Jehad al-Binah, more generally, is a construction agency that provides infrastructure and employment to the population of Southern Lebanon. ${ }^{172}$ These multiple and overlapping administrative structures have greatly increased the amount of popular support-securing outputs that Hezbollah produces and has secured the group a significant amount of active and passive popular support. Similarly, in Ethiopia, "the Tigray People's Liberation Front (TPLF) designed and implemented an elaborate set of administrative structures intended to generate the willing support of the civilians." 173

Historical evidence confirms that one way in which an insurgent group can buildup its administrative presence is by building its infrastructure and organization in an area. The evidence presented also supports the notion that insurgencies tend to develop a deeper and broader administrative presence in and around the people in order to obtain higher levels of popular support through the production of a higher quantity of remunerative compensation and preference manipulation tactics. Such evidence is further suggestive of the idea that there could be scale economies at work as a rebel group's administrative presence expands through organization building, although, without having detailed information on a group's fixed costs and the quantity of output produced, a definitive statement cannot be made.

\subsection{6 - Expansion Via the Incorporation of Pre-Existing Socio-Political Organizations}

\footnotetext{
${ }^{172}$ For a far more thorough description of these organizations, and of Hezbollah as a whole, see, for example, Martin Rudner, "Hizbullah: An Organizational and Operational Profile," International Journal of Intelligence and Counterintelligence, Vol. 23, no. 2 (2010), 229-231.

${ }^{173}$ Nelson Kasfir, "Guerrillas and Civilian Participation: The National Resistance Army in Uganda, 19811986," The Journal of Modern African Studies, Vol. 43, no. 2 (June 2005), 272.
} 
The second general method through which an insurgency can expand its administrative presence, both in term of increased depth and increased breadth, is by incorporating preexisting socio-political organizations into the rebellion's own super-ordinate administrative structure. ${ }^{174}$ When done effectively, an insurgency benefits from incorporating pre-existing infrastructure and organizations through reduced average costs of production in the long run. Reduced average costs emerge because a lot of the initial fixed costs that are needed in order to establish insurgent administration, either broadly into new geographical areas or deeper into the sociological bases of a population in a given area, have already been paid by the pre-existing socio-political organization. By effectively incorporating these groups into the overarching insurgent administrative structure, a rebel group can generally obtain lower average costs than a group that buildsup its administrative presence from scratch. What this suggests is that an insurgency that can expand through effective incorporation and assimilation of pre-existing sociopolitical organizations is likely, other things being equal, to have lower average costs per unit of popular support-securing output than a group that expands through only wholly organizational building. Overall, the core implication of this postulate is that a group that can expand by effectively incorporating and assimilating pre-existing networks should be more likely to secure organizational growth than a rebel group that only builds-up it own administrative presence in a given area, since the former effectively has lower fixed costs than the latter.

Historical evidence suggests that many insurgencies do often expand by incorporating in pre-existing socio-political organizations, rather than simply relying on

\footnotetext{
${ }^{174}$ For an insightful article on how variation in a group's incorporation of pre-existing groups affects its ability to absorb resource rents and external support, see Paul Staniland, "Organizing Insurgency: Networks, Resources, and Rebellion in South Asia," International Security, Vol. 37, no. 1 (2012), 142-177.
} 
from-scratch organization building. The evidence also suggests that these efforts often yield high levels of popular support. In Nepal, for example, the Maoists actively incorporated pre-existing ethnic and regional socio-political group into the rebellion's organization, which facilitated the rapid spread of the insurgency in the $1990 \mathrm{~s} .{ }^{175}$ Likewise, during the 1930s in China, "The peasant mass movement led by the CCP was an adaptation of the infrastructure provided by this tradition [of local self-defence]. One element of the CCP's power in the rural areas stemmed from its ability reshuffle and reintegrate this institution into its own revolutionary infrastructure." ${ }^{176}$ During the SovietAfghan War in the 1980s, "The mobilization of the countryside," as Gilles Dorronsoro points out, "took place in the context of local solidarity networks, organised around 'commanders'," who were loosely subordinated to the seven Peshawar-based Mujahideen factions. ${ }^{177}$ Similarly, in the Philippines, while the relationship between the insurgency and pre-existing socio-political organizations was prone to betrayal and disruption, "the MNLF, especially in the early days, relied on the help of certain prominent traditional leaders" to obtain an administrative presence in a given area and to mobilize popular support. ${ }^{178}$ Before the outbreak of hostilities in 1980, the expansion of the Shining Path's administrative presence in 1977 and 1978 was "assisted by the absorption of a number of small [pre-established] revolutionary sects." ${ }^{179}$ In Indonesia, in "villages in which the PKI established its influence in the 1950's and early 1960 's, ... the Party relied mainly on

\footnotetext{
${ }^{175}$ Sudheer Sharma, "The Maoist Movement: An Evolutionary Perspective," in Michael Hutt, ed., Himalayan 'People's War': Nepal's Maoist Rebellion (London: Hurst \& Company, 2004), 41-42.

${ }^{176}$ Tetsuya Kataoka, Resistance and Revolution in China: The Communists and the Second United Front (Berkeley: University of California Press, 1974), 104.

177 Gilles Dorronsoro, Revolution Unending: Afghanistan, 1979 to the Present (New York: Columbia University Press, 2005), 93.

${ }^{178}$ Thomas M. McKenna, Muslim Rulers and Rebels: Everyday Politics and Armed Separatism in the Southern Philippines (Berkely: University of California Press, 1998), 165.

${ }^{179}$ Lewis Taylor, Shining Path: Guerrilla War in Peru's Northern Highlands, 1980-1997 (Liverpool: Liverpool University Press, 2006), 7.
} 
traditional patron-client and authority relationships to establish its organization." ${ }^{180}$ In the Western Sahara, the Polisario Front came to control the Saharawi population by absorbing the "old pre-revolutionary tribal councils." ${ }^{181}$ Lastly, in Algeria during the war of independence against the French, "wherever possible, the guerrillas borrowed from older organizations" as they expanded. ${ }^{182}$ These examples show that rebel groups often expand via the incorporation of pre-existing socio-political organizations into the insurgency's overarching administrative structures. The aimed for, and commonly obtained, result is that insurgent groups are able to obtain high levels of popular support.

\footnotetext{
${ }^{180}$ Rex Mortimer, "Traditional Modes and Communist Movements: Change and Protest in Indonesia," in John Wilson Lewis, ed., Peasant Rebellion and Communist Revolution in Asia (Stanford: Stanford University Press, 1974), 114.

181 Jon Lee Anderson, Guerrillas: Journeys in the Insurgent World (New York: Penguin Books, 2004), 172.

${ }^{182}$ Alf Andrew Heggoy, Insurgency and Counterinsurgency in Algeria (Bloomington: Indiana University Press, 1972), 107.
} 
The general relationship between the expansion of a rebel group's administrative presence and the emergence of economies of scale is presented in Figure 3.3. This figure shows that as an insurgency's administrative presence increases, its average cost per unit of popular support-securing output - that is, remunerative compensation and preference manipulation tactics - declines. The two arched curves, $\mathrm{AC} 1$ and $\mathrm{AC} 2$, are the average cost curves of two rebel groups, one that builds its organization from scratch as it expands (AC1) and one that expands through the effective assimilation and integration of pre-existing socio-political organizations (AC2). A rebel group along the $\mathrm{AC} 1$ curve would have an average cost per unit of output A1 at a low-to-medium scale administrative presence, $\mathrm{AP}(\mathrm{M})$. If this group was to expand its administrative presence 
through more original organizational building, either deeper into an area's sociological base or across territory, its administrative presence would grow in scale to, say, $\mathrm{AP}(\mathrm{H})$. As its administrative presence increases from $\mathrm{AP}(\mathrm{M})$ to $\mathrm{AP}(\mathrm{H})$, its average cost per unit of popular support-securing output falls from A1 to A3.

\section{Figure 3.3. Insurgent Group Administrative Presence and the Average Cost per} Unit of Production



Insurgent Group Administrative Presence

Having incorporated some pre-existing socio-political groups into its overarching organizational structure, an insurgent group on the $\mathrm{AC} 2$ curve could obtain an average cost per unit of remunerative compensation or preference manipulation tactics, A2, at a low level of administrative presence, $\mathrm{AP}(\mathrm{L})$. If the rebellion was able to expand further by effectively absorbing more pre-existing socio-political organizations, the scale of the 
rebel group's administrative presence could increase to, say, a high administrative presence, $\mathrm{AP}(\mathrm{H})$. At this level of administrative presence, the rebel group that effectively expands via assimilation and incorporation of pre-existing socio-political organizations would have an average cost of A4 per unit of popular support-securing outputs that it produced.

Two interesting intuitions emerge when the two theoretical rebel groups are compared. First, since the group that is expanding by effectively assimilating and incorporating pre-existing networks into the over-arching organizational structure of the insurgency has a lower average cost per unit of popular support-securing output than the group that builds its administrative presence from scratch, the expectation would be that the former group should be able to grow faster and to a larger size than the latter group, everything else being equal. A second intuition that is more directly relevant for the next chapter on the insurgency's military position relative to the state is that a rebel group that expands through effective incorporation and assimilation should be able to obtain as much if not more popular support at any scale of administrative presence when compared to a group that grows purely through original organizational building.

\subsection{7 - Conclusions}

In sum, I have argued that an insurgent group can often obtain organizational growth and grow to a large overall size by increasing the scale of its administrative presence. Such an investment raises the rebel group's fixed costs, although the extent to which fixed costs are increased depends upon whether the insurgency is expanding its presence via the incorporation of pre-existing socio-political networks (typically cheaper) or through original organization building (typically more expensive). While a rebel group's fixed 
costs are increased as the scale of its administrative presence rises, the insurgency's ability to produce popular support-securing outputs also goes up. As output increases, economies of scale can emerge as the group's fixed costs are distributed over a larger amount of outputs. In the end, an insurgency can often produce its way to organizational growth by expanding the scale of its administrative presence.

\section{3 - What rebel group organizational structure leads to the highest growth potential?}

The last section corrected one deficiency with the simplified profit margin model presented in Figure 3.1, namely, the assumption that an insurgency's production potential is unbounded, or at least not related to its fixed costs and production potential. The other problem with the simplified model is that there is, as it currently stands, no account for how variable costs and fixed costs related to one another. I argue here that fixed costs and variable costs are inversely related. Investing in certain aspects of an organization's structure (more precisely, centralizing the insurgency's organization) can increase an insurgency's fixed costs and, at the same time, lower its variable costs by improving the group's productive efficiency. If variable costs are reduced more than fixed costs are increased, then total costs fall and the insurgency is more likely to be able to obtain organizational growth.

In what follows, I show how an insurgency can invest in organizational centralization in order to reduce its variable costs per unit of popular support-securing output produced. In making this argument, I first define three key concepts: variable costs, production efficiency, and organizational centralization. I then present a variation of the profit margin model originally presented in its simplest form in Figure 3.1. In 
discussing the expanded model, I outline how an investment in the fixed costs of organizational centralization can actually reduce the variable costs that an insurgency pays per unit of output produced. Reduced variable costs, in turn, can lower the group's total costs, provided that the increase in the rebellion's fixed costs are less than the reduction in its variable costs. I then contrast centralized and decentralized organizational types to show why the former is often efficiency enhancing but more costly to set up and maintain than the latter. As before, I substantiate my arguments about the various reasons why centralization is typically more efficient for an insurgency with broad-based historical examples.

\subsection{1 - Some Definitions: Variable Costs, Production Efficiency, and Organizational Centralization}

To understand how centralization can enhance a rebel group's productive efficiency and reduce its variable costs, it is first necessary to clearly conceptualize the three core components of this claim: variable costs, what efficiency means, and how organizational centralization and decentralization are defined.

While variable costs were briefly defined before in section 3.1, a short reiteration is warranted here. Variable costs are composed of both the cost of the raw material (labour and capital) that go into producing a unit of output and the cost of the production process itself, which can be more or less efficient. For example, a variable cost of 100 dollars per unit might be composed of 65 dollars for raw material and 35 dollars that accrue due to current production practices and routines. Assuming that the price of raw materials is constant, an increase in the efficiency of a rebel group's production process leads to a lower variable cost per unit. 
Efficiency is defined as the ratio of inputs expended in the production process to the quantity of outputs produced. For a given level of fixed costs, higher variable production costs entail a worse input-to-output ratio, meaning less efficient production; whereas lower variable production costs entail a better input-to-output ratio, resulting in more efficient production. Hence, insurgent groups that are attempting to obtain organizational growth often need to be producing outputs as efficiently as possible, although variable production costs can never actually reach zero.

Organizational centralization and its opposite, organizational decentralization, are, at their root, organizing principles that denote how mutually reliant all the subunits of the organization are. The subunits in a centralized organization are generally mutually reliant to a significant degree, which means that each unit depends upon another unit in some way in order to accomplish its primary task. A subunit might, for example, require direction from leadership. Subunits in more decentralized organizations are less mutually reliant, which allows each unit to undertake its core tasks without needing to rely upon other parts of the broader organization. As I detail below, centralized organizations tend to be more efficient than decentralized groups due to their hierarchical decision-making, larger coordination mechanisms, greater specialization, and greater control and monitoring mechanisms.

\subsection{2 - An Expanded Profit Margin Model: Rebel Group Organizational Centralization and Variable Costs}

Having defined the core concepts of variable costs, efficiency and organizational centralization, I now present a modified profit margin model that formalizes how an insurgency's investment in centralizing its organizational structure increases a rebel 
group's fixed costs but decreases its variable costs. If the reduction in the variable costs that an insurgency obtains by centralizing is greater than the increase in fixed costs that it has to pay to develop and maintain this more complex form of organization, then the group's total costs fall and the rebellion's ability to grow in size over time increases.

\section{Figure 3.4. Investment in Centralization and Group Growth}



Figure 3.4 formalizes this claim. In this case, an insurgency has a fixed total revenue curve TR(1) and an initial total cost curve TC(1). It also has to pay an initial fixed cost of $\mathrm{FC}(1)$ to maintain the organization that it already has. Comparing the amount of total revenue (popular support) that a group receives before and after an 
investment in centralization provides some clear insight into the potentially positive effect that such organizational change can have on a group's ability to obtain growth. Assume that the rebel group is initially producing Q1 amount of popular support-securing outputs and receiving TR amount of popular support in exchange. Further assume that the insurgency needs more popular support in order to effectively challenge the regime.

Since the insurgency in this case needs to grow larger, it must try to secure more organizational growth. One route to higher levels of growth in this instance is for the insurgency to invest in its organizational structure, moving from a more decentralized to a more centralized group form. Centralized organizations are more costly to maintain than decentralized organizations, as centralization requires, as I detail below, greater decision-making, coordination, specialization, and control and monitoring mechanisms, each of which is costly to establish and maintain. Investing in organizational centralization, therefore, raises the fixed costs that the insurgency needs to pay, shifting the fixed cost curve upwards from $\mathrm{FC}(1)$ to $\mathrm{FC}(2)$. Since centralization is typically efficiency enhancing (another point which I elaborate on below), the variable costs that an insurgency pays to produce a unit of output generally decline as the group's centralization goes up. A decline in the rebellion's variable costs flattens the slope of the total cost curve, moving it from, say, $\mathrm{TC}(1)$ to $\mathrm{TC}(2)$. This decline in production costs allows the group to produce more popular support-securing output, Q2, while still generating a profit (organizational growth). Even though the rate at which the population provides support to the insurgency remains the same (TR(1) is constant), a rebel group that invests in organizational centralization and reduces its variable costs is now able to 
secure a higher level of popular support, TR2, than it did previously. What this means is that the group is able to grow faster and larger than it did previously and now stands a better chance of effectively challenging the state.

\subsection{3 - Production Process Costs and Rebel Group Efficiency}

Four major costs factor into a rebel group's production process and can inhibit the ability of an insurgency to produce remunerative compensation and preference manipulation tactics at an optimal level of efficiency. In particular, high decision-making, coordination, opportunity, and agency costs can all reduce the efficiency of a rebel group's production of popular support-securing outputs. At its simplest level, each cost increases as an insurgent group's organizational decentralization rises. The reason for this positive relationship between decentralization and higher production costs is that organizational decentralization itself tends to result in less group hierarchy, weaker coordination mechanisms, less organizational specialization, and weaker monitoring and compliance mechanisms. As these organizational mechanisms decline, the four costs become more pronounced and the efficiency of a group's production falls. Increasing organizational centralization, in contrast, tends to result in stronger hierarchy, more effective coordination mechanisms, more organizational specialization, and better monitoring and compliance mechanisms. As these mechanisms increase in scope and effectiveness, the four costs decline and the efficiency of a group's production of remunerative compensation and preference manipulation tactics increases. As the efficiency of an insurgency's production of popular support-securing outputs goes up, its variable costs fall and the group should be more easily able to secure organizational growth over time. 
The general relationship between centralization, cost reducing mechanisms, and costs that hamper a group's production efficiency is laid out in Figure 3.5.

\section{Figure 3.5. Increasing Organizational Centralization and the Costs of Production}

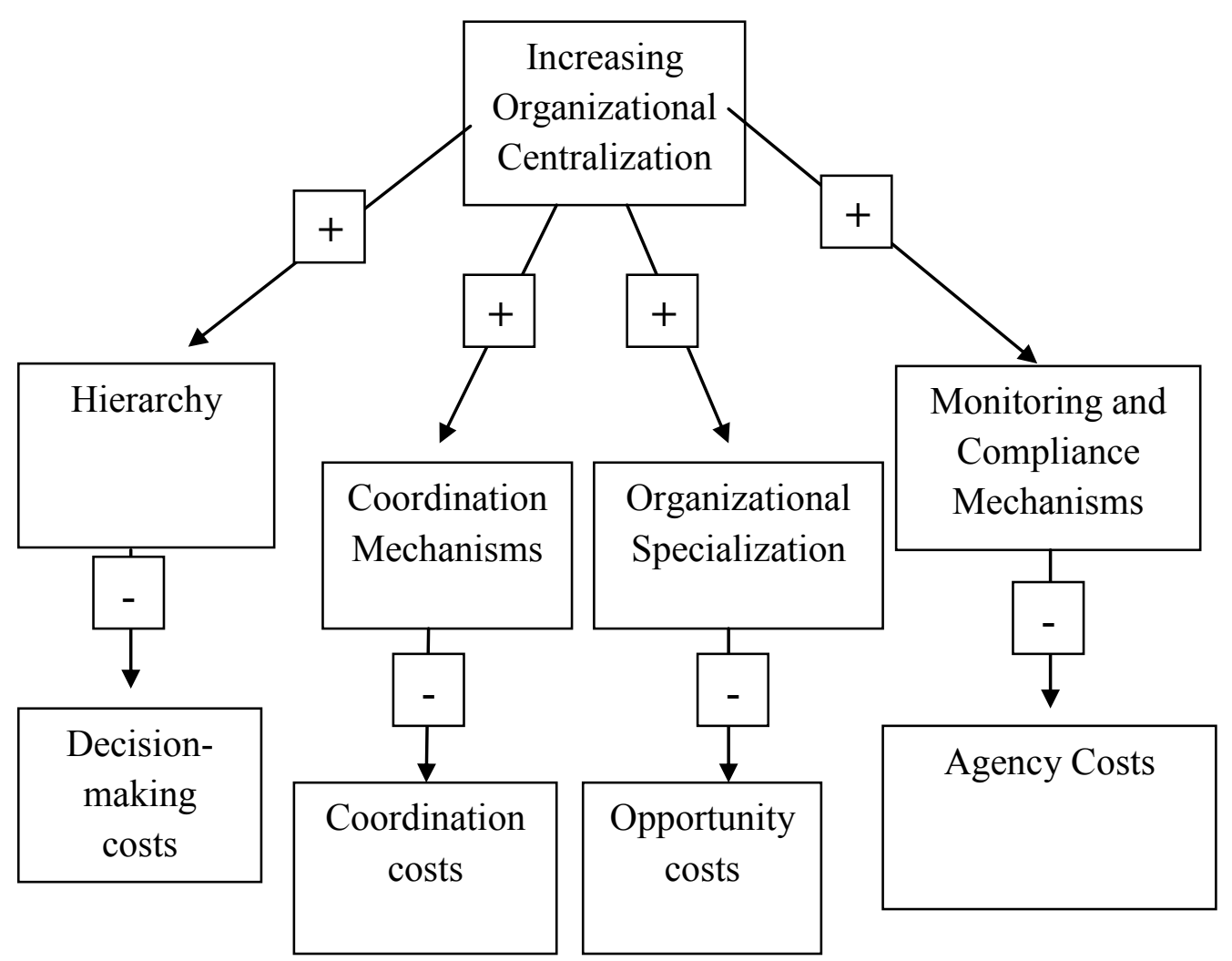

In the following four subsections, I describe each type of cost and how it can make a rebel group less efficient at producing popular support-securing outputs. I also explain how a particular organizational characteristic can address each cost. I further show how each cost-correcting characteristic is, in turn, an integral part of organizational centralization. I then pinpoint how the various aspects of centralized organization that redress each type of variable cost are themselves costly and require that an insurgency 
increase its fixed costs if it is to develop and maintain these cost-correcting mechanisms.

Lastly, I also highlight why larger group size exacerbates the extent of each cost and further incentivises organizational change towards increased levels of centralization as an insurgency gets larger.

One final caveat is in order. The following four subsections disaggregate organizational centralization and decentralization into discrete costs and corrective mechanisms. Invariably, the disaggregation of these concepts, while analytically possible, is empirically suspect. Real organizations are far less neat and tidy than the depiction presented in the following sections. While disaggregating the concept of organizational structure into its component parts is useful and provides a lot of analytical leverage, I caution the reader to remember that the real world is messy. ${ }^{183}$

\subsection{4 - Decision-Making Costs, Hierarchy, and Organizational Centralization}

In order to produce outputs, an insurgent group needs to make a conscious decision about what combination, allocation, and distribution of inputs best maximizes the amount of output that can be produced. How an insurgent organization comes to a decision on a particular course of action affects the amount of decision-making costs that are entered into the group's production relationship. Decision rules can range from hyper-democratic, such as a situation requiring unanimous agreement, to hyper-hierarchical, where most, if not all, relevant decisions are made by only a few individuals. The more costly the decision rule, the less efficient a group's production process becomes, with all the associated effects on an insurgency's ability to secure growth.

\footnotetext{
${ }^{183}$ I am grateful to David Jardine for always reminding me of this point. See, also, Alfred North Whitehead, Science and the Modern World (Cambridge: Cambridge University Press, 1926), 64, 72.
} 
Generally, decision-making costs, defined in terms of the time and effort needed to reach a decision, increase as the number of people directly involved in the decisionmaking process rise. ${ }^{184}$ The inverse relationship between decision-making costs and the number of relevant decision-makers suggests that more democratically organized groups, where decisions are made by many people, have comparatively higher decision-making costs. As a result, more democratic groups should also have a less efficient production process. In contrast, groups that are more hierarchically organized with fewer decision makers, as well as "clear departmental boundaries, clean lines of authority, detailed reporting mechanisms, and formal decision making procedures" have comparatively lower decision-making costs. ${ }^{185}$ And, with lower decision-making costs, more hierarchical groups should generally be more efficient at producing remunerative compensation and preference manipulation tactics.

The size of the organization also factors into the optimal decision-making rule for each group. Larger group size ensures that fewer decision-makers as a proportion of the group's total membership is the most efficient alternative. A smaller group, however, can reach efficient decisions with a higher proportion of its membership being involved in the decision making process. ${ }^{186}$ For a group of any medium-to-large size, hierarchy is an efficiency enhancing organizational characteristic that reduces the amount of decisionmaking costs that are introduced into the production process. As Gary J. Miller notes,

A firm's manager who permits other employees to share in the decision making of the firm could create organizational instability, indecisiveness,

\footnotetext{
184 James M. Buchanan and Gordan Tullock, The Calculus of Consent: Logical Foundations of Constitutional Democracy (Indianapolis: Liberty Fund, 2004), 65.

${ }^{185}$ Walter Powell, "Neither Market nor Hierarchy: Network Forms of Organization," Research in Organizational Behavior, Vol. 12 (1990), 303.

${ }^{186}$ For an extension of Buchanan and Tullock's model on this point, see Milton Z. Kafoglis and Richard J. Cebula, "The Buchanan-Tullock Model: Some Extensions," Public Choice, Vol. 36, no. 1 (1981), 181-183.
} 
inefficiency, or manipulability. Firms that seek to realize the efficiency potential in specialized, interdependent team production processes not only must create authoritative group decision structures, but must also centralize power. The inevitable result is hierarchy. ${ }^{187}$

The number of leadership positions in hierarchically organized groups is relatively small compared to more democratic forms of organization, so the amount of decision-making costs that get added to the production process tend to fall as the group's hierarchy increases. For an insurgent group, then, hierarchy is efficiency enhancing, which reduces the organization's variable costs. And, by extension, hierarchically organized groups should be more efficient, and, as a result, should find it easier to secure higher levels of organizational growth, everything else being equal.

Hierarchy is, moreover, a core component of organizational centralization, as both concepts involve the authoritative control of subordinates by super-ordinate leadership. ${ }^{188}$ Typically, a group becomes more centralized organizationally when its decision-making structure becomes more hierarchical. Insurgent organizations, therefore, can vary from more centralized groups, with a prevalent hierarchical decision-making structure, to a more decentralized organization with a strongly democratic decisionmaking rule in place.

For a centralized rebellion, maintaining a functional hierarchy requires that the insurgency raise its fixed costs over what they are under a more decentralized organizational structure. For example, a clear pattern of authority needs to be established and maintained if a hierarchical decision-making system is going to function. Maintaining such a system can often require that benefits, such as wages or status, be

\footnotetext{
${ }^{187}$ Gary J. Miller, Managerial Dilemmas: The Political Economy of Hierarchy (Cambridge: Cambridge University Press, 2002), 25.

${ }^{188}$ Gary Johns and Alan M. Saks, Organizational Behaviour: Understanding and Managing Life at Work (Toronto: Pearson/ Prentice-Hall, 2005), 461.
} 
paid to members at all rungs of the hierarchical system. These benefits are not a part of the variable costs associated with the actual process of production, but are, instead, simply used to maintain the efficacy of the decision-making rule and the edifice that codifies it. Decentralized organizations obviously need to pay some wages to their membership as well. Plausibly, however, these payments are generally less extensive than in hierarchical systems, since individuals within a decentralized organization are partially compensated for their actions through their increased autonomy rather than through material compensation. ${ }^{189}$

Comparative historical evidence suggests that more hierarchical rebel groups with fewer decision-makers are better at producing remunerative compensation and preference manipulation tactics than more democratically organized groups. In Angola, for instance, the hierarchical organization of UNITA was central to the efficient production of outputs used to secure popular support. As Bard O' Neill notes,

Visitors to UNITA areas in the southeast consistently paint a picture of a smoothly functioning central governing apparatus that extends its authority to the village level and manages to provide basic services. UNITA's government has various ministries (e.g., health, information, natural resources, and so forth) and a radio station. ... UNITA's ministries also manage more than nine hundred primary and secondary schools and the export of diamonds, ivory, timber, and other resources. ${ }^{190}$

Similarly, much of the LTTE's production of remunerative compensation and preference manipulation tactics was linked, ultimately, to the central leadership of the insurgency and the direction and decision-making of the main leader, Thiruvenkadam Velupillai

\footnotetext{
${ }^{189}$ On the idea that hierarchical decision-making rules impose individual costs that would presumably need to be compensated for by higher wages, see James M. Buchanan and Gordan Tullock, The Calculus of Consent: Logical Foundations of Constitutional Democracy (Indianapolis: Liberty Fund, 2004).

${ }^{190}$ Bard E. O'Neill, Insurgency and Terrorism: Inside Modern Revolutionary Warfare (Dulles: Brassey's Inc., 1990), 93.
} 
Prabhakaran. As Neil De Votta points out, "The LTTE has a Central Committee that basically approves Prabhakaran's dictates and political military wings that ensures that those dictates are implemented. While the political wing covers areas such as the courts, economic development, health care, education, and the arts and culture, the military wing oversees policing, recruitment, finance, intelligence gathering, and special operations." 191 As a result of these political and military efforts, moreover, the LTTE received a high degree of active and passive popular support from the Tamil population of Sri Lanka. In a similar fashion, the efficiency with which the Shining Path in Peru undertook military and productive activity was similarly increased due to the organization's strong hierarchy. ${ }^{192}$

In contrast, during the early stages of the Huk rebellion in the Philippines, Jose Lava, a leader of the communist party, reflectively noted that a part of the party's marginalization in the early stages of the peasant rebellion was due to the fractured nature of the party's leadership, which inhibited efficient decision-making and the effective implementation of policies that could have won the communists more popular support through the efficient production of preference manipulation tactics and remunerative compensation. As Lava noted, "The record of the regular PB [Politburo] and the SF [Second Front] from September 1946 to January 1947 is one of continuous conflicts and contradictions, with mutual accusations of demoralization; inefficiency, etc., resulting in their failure to give political and organizational guidance to the lower Party organs." 193

\footnotetext{
${ }^{191}$ Neil De Votta, Blowback: Linguistic Nationalism, Institutional Decay, and Ethnic Conflict in Sri Lanka (Stanford: Stanford University Press, 2004), 170.

${ }^{192}$ Cynthia McClintock, Revolutionary Movements in Latin America (Washington: United States Institute of Peace Press, 1998), 91.

${ }^{193}$ Jose Lava, cited in, Benedict J. Kerkliet, The Huk Rebellion: A Study of Peasant Revolt in the Philippines (New York: Rowman \& Littlefield Publishers, Inc., 2002), 187.
} 
In the context of Figure 3.4, an insurgent group can invest in its organizational structure by establishing a system of hierarchical decision-making. Such an investment raises the fixed cost that the insurgency needs to pay in order to maintain the new, more expensive system, as the benefits paid to individuals to maintain the decision-making system go up as hierarchical organization rises. Despite these rising fixed costs, the insurgency becomes more efficient at producing popular support-securing outputs as its decision-making costs fall. Improved efficiency, in turn, reduces the insurgency's variable costs. If the decline in variable costs is greater than the increase in fixed costs, then total costs fall and the ability of the rebel group to obtain organizational growth over time go up.

\subsection{5 - Coordination Costs, Coordination Mechanisms, and Organizational Centralization}

Coordination costs are the second type of cost that can factor into an insurgent organization's production of remunerative compensation and preference manipulation tactics. Coordination refers to the coming together of inputs, people and capacity for the purpose of action - in this case, for the purpose of producing popular support-securing outputs. The output of coordinated production is often greater than the sum of all individual contributions. ${ }^{194}$ For example, by working independently, two insurgents could potentially produce, say, 30 units of remunerative compensation each - for a total production of 60 units. Through a coordinated team production effort, however, the two

\footnotetext{
${ }^{194}$ In the literature on the economics of organization, coordination costs are often known as team production costs. See, for example, Armen A. Alchian and Harold Demsetz, "Production, Information Costs, and Economic Organization," The American Economic Review, Vol. 62, no. 5 (1972), 777-795. Alchain and Demsetz also note that multiple inputs and multiple "owners" of inputs are needed for team production costs to emerge. I take these conditions as a given in the context of my analysis as they are almost always present.
} 
insurgents could produce, say, 80 units of remunerative compensation - or 20 more units than could have been produced through individual action. This process is what Russell Hardin has described as the "super-additive" effect of coordinated individual behaviour during revolution, where coordinated production often ensures that the output is greater than the sum of each individual's discrete contribution. ${ }^{195}$

Properly coordinating the distribution and allocation of inputs, however, is costly and coordination breakdowns can actually result in a worse output level than if each individual was producing in isolation. Coordination costs are all the costs that a rebel group needs to bear in order to successfully bring together labour and capital for the purpose of production. By raising the costs of the production process, greater coordination costs reduce the efficiency of an insurgent group's production of outputs. Put another way, compared to an insurgency that successfully coordinates its production, a rebel group with high coordination costs should have fairly high variable cost per unit of output produced.

Coordination can be obtained in a spectrum of ways. As Ronald Coase originally conceived the problem, individuals hold the raw inputs of production - labour and capital - which need to be combined in the aggregate for any volume of finished product to be created. ${ }^{196}$ Each holder of the means of production provides inputs in exchange for some amount of compensation. Two methods, or really two poles along a continuum, exist to ensure that inputs are effectively coordinated for the purpose of production: a market exchange mediated by a price mechanism and the directed coordination of labour and capital allocation and distribution by some overarching authority.

\footnotetext{
${ }^{195}$ Russell Hardin, One for All: The Logic of Collective Action (Princeton: Princeton University Press, 1995), 37.

${ }^{196}$ Ronald Coase, "The Nature of the Firm," Economica, Vol. 4, no. 16 (1937), 386-405.
} 
In the market method of coordinated production, every exchange and aggregation of inputs needs to be deliberately negotiated. This process of negotiation takes time, is prone to failure, and introduces additional coordination costs into the production process. ${ }^{197}$ The alternative method for successfully coordinating inputs for the purpose of production is to substitute market exchange transactions for "the entrepreneur-coordinator, who directs production." ${ }^{198}$ When present, an entrepreneur coordinator authoritatively allocates resources with an eye toward enhancing the productive potential of the group. For this substitution to make economic sense, the cost of the entrepreneur coordinator must be less than the coordination costs that would otherwise be incurred during the process of production in a market exchange system. Given the ubiquity of firms, Coase concludes that there are usually some cost-saving advantages (efficiency gains) for a firm to use an "entrepreneur-coordinator" to plan and authoritatively coordinate the allocation and distribution of inputs rather than relying on the market exchange method. Like with firms, few insurgent organizations rely completely on market exchange to facilitate coordination, suggesting that here too authoritative coordination mechanisms tend to reduce costs and enhance group efficiency.

Research on group production has also found that coordination costs increase as a group increases in size. ${ }^{199}$ Essentially, when the number of parts that need to be coordinated rises, the cost of coordinating the allocation and distribution of inputs rises as well. Rising coordination costs occur regardless of the precise method of coordination that is used, although the method would certainly affect the rate at which cost escalate as

\footnotetext{
${ }^{197}$ Ronald Coase originally termed these costs "marketing costs" and they are probably most commonly known as transaction costs.

${ }^{198}$ Ronald Coase, "The Nature of the Firm," Economica, Vol. 4, no. 16 (1937), 388.

${ }^{199}$ Ivan D. Steiner, Group Processes and Productivity (New York: Academic Press, 1972).
} 
a rebel group grew in size. When coordination costs rise, moreover, the input-to-output ratio deteriorates and the group is affected with less efficient production, so larger groups tend to have less efficient production. ${ }^{200}$

For a firm (or a rebel group) to be more efficient than the market at allocating the distribution of inputs and compensation, it needs to have effective and comparatively cost-efficient coordination mechanisms. Coordination mechanisms - including supervisors, formal plans, and the standardization of skills, outputs, and specific production procedures - enhance the management of inputs in a production process. ${ }^{201}$ When present, these mechanisms provide the leadership of the organization with the ability to directly and deliberately coordinate the allocation and distribution of inputs towards the most efficient possible combinations at generally less cost than more market - or self-directed - processes of resource distribution, combination, and allocation. ${ }^{202}$ As with a firm in the production process, an insurgent organization that has better coordination mechanisms tends to be more efficient because it has to absorb fewer coordination costs in its production of remunerative compensation and preference manipulation tactics. In turn, such an organization should have lower variable costs and find it easier to secure organizational growth over time.

As with hierarchy as a group characteristic, effective coordination mechanisms, such as supervisors, formal plans, and standardization, are a core component of

\footnotetext{
${ }^{200}$ Richard Z. Gooding and John Wagner III, "A Meta-Analytic Review of the Relationship between Size and Performance: The Productivity and Efficiency of Organizations and their Subunits," Administrative Science Quarterly, Vol. 30, no. 4 (1985), 462-481.

${ }^{201}$ For a review of the many different forms of coordination mechanisms in business firms, see Gary Johns and Alan M. Saks, Organizational Behaviour: Understanding and Managing Life at Work (Toronto: Pearson/ Prentice-Hall, 2005), 455-459.

${ }^{202}$ Gary J. Miller, Managerial Dilemmas: The Political Economy of Hierarchy (Cambridge: Cambridge University Press, 2002), 52.
} 
organizational centralization. Such mechanisms tend to be the most effective in more centralized organizations because each can be buttressed by other aspects of centralization, with, for example, hierarchical decision-making bolstering the effectiveness of supervisors and formal planning. Indeed, research has consistently found that organizational centralization increases the level of intra-organizational coordination that a group can achieve ${ }^{203}$ As Abdulkader H. Sinno notes, "The highest levels of coordination, for which control is a prerequisite, can only be achieved in centralized organizations." 204

Finally, from an organizational perspective, obtaining higher levels of coordination, and so lower coordination costs, is certainly not costless. Indeed, while coordination costs are generally higher in groups that adopt a market method of coordination for the reasons noted above, the fixed costs of maintaining this sort of system to coordinate productive activities is truly negligible. In contrast, a group that adopts a centralized structure with robust coordination mechanisms has lower coordination costs, but higher fixed costs associated with maintaining formal plans, supervisors, standardization, and effective communication systems. Importantly, these coordination mechanisms generally need to be maintained regardless of whether coordination for the purpose of production actually occurs. The reason being that developing functional coordination mechanisms on short notice is difficult to accomplish and quite prone to failure.

Historical examples illustrate how coordination mechanisms helped various rebel groups produce remunerative compensation and preference manipulation tactics and win

\footnotetext{
${ }^{203}$ James March and Herbert Simon, Organizations (Oxford: Blackwell Publishing, 1993), 3;

${ }^{204}$ Abdulkader H. Sinno, Organizations at War: In Afghanistan and Beyond (Ithaca: Cornell University Press, 2008), 60.
} 
popular support. In the late 1970s, for instance, the ZANU rebels in Zimbabwe established specialized, coordinating "branch committees composed of a cluster of villages ... to improve efficiency of the [resource mobilization] system and to ensure that the same villages were not being asked to meet demands from many guerrilla groups."205 Likewise, in Sri Lanka, "the LTTE established the Tamil Eelam Education Council (TEEC) to coordinate the provision of education," with the result of such coordinated provision of educational services being higher levels of popular support for the insurgency. ${ }^{206}$

Insurgent organizations with effective coordination mechanisms, therefore, can better distribute, allocate, and combine their raw inputs and capacity for the purpose of producing remunerative compensation and preference manipulation tactics. Rebel groups with weaker coordination mechanisms must rely upon more market-based methods of coordination and will generally incur higher coordination costs because each transaction needs to be negotiated and is prone to failure or delay. The inverse is true regarding each type of group's fixed costs. Here, groups with robust coordination mechanisms generally have higher fixed costs that are needed in order to maintain effective coordination mechanisms. Rebel groups that rely upon market methods of coordination, in contrast, do not need to maintain much in the way of coordination mechanisms, so fixed costs for this type of organization are usually lower. If the efficiency gains that are to be had through effective coordination mechanisms outweigh the fixed costs that need to be incurred to

\footnotetext{
${ }^{205}$ Norma J. Kriger, Zimbabwe's Guerrilla War: Peasant Voices (New York: Cambridge University Press, 2008), 118.

${ }^{206}$ Zachariah Cherian Mampilly, Rebel Rulers: Insurgent Governance and Civilian Life During War (Ithaca: Cornell University Press, 2011), 121.
} 
maintain these mechanisms, then an insurgency's total costs are lower and the group is more likely to obtain organizational growth over time.

\subsection{6 - Opportunity Costs, Organizational Specialization and Organizational Centralization}

Opportunity costs are a third type of cost that is typically higher in decentralized groups, when compared to centralized insurgencies. An opportunity cost is "whatever must be given up to obtain some item." ${ }^{207}$ In other words, nothing is free. In this case, an insurgent group can be afflicted with the opportunity cost of missed efficiency gains that frequently result from a lack of organizational specialization. Adam Smith classically noted that specialization improves productivity considerably, with the efficiency of the production process rising accordingly. ${ }^{208}$ Likewise, Max Weber concluded that organizational specialization was one of the core features of effective administrative bureaucracies. ${ }^{209}$ Indeed, recent empirical evidence supports the idea that specialization both increases output and reduces production costs, making the production process more efficient, although over-specialization can clearly result in a loss of efficiency. ${ }^{210}$ At its core, organizational specialization involves the allocation of resources toward specific tasks, such as, in the case of a rebel group, decision-making, administration, service provision, coercion and intimidation, war-fighting, and propaganda dissemination. Organizational specialization can occur both vertically and

\footnotetext{
${ }^{207}$ N. Gregory Mankiw, Ronald D. Kneebone, Kenneth J. McKenzie, and Nicolas Rowe, Principles of Microeconomics 4th ed., (Toronto: Thomson Nelson, 2008), 521.

${ }^{208}$ Adam Smith, The Wealth Of Nations (New York: Oxford University Press, 1998), 15.

${ }^{209}$ Peter M. Blau and W. Richard Scott, Formal Organizations: A Comparative Approach (Stanford: Stanford University Press, 2003), 32-34.

${ }^{210}$ James C. Dumville and Franciso A. Torano, "Division of Labor, Efficient? Empirical Evidence to Support the Argument," SAM Advanced Management Journal, Vol. 62, no. 2 (Spring 1997), 16-20.
} 
horizontally. ${ }^{211}$ Vertical specialization, in many ways a core component of both hierarchical organization and effective coordination mechanisms, assigns specialized tasks to leadership and different, yet equally as specialized tasks, to lower level organizational units. Horizontal specialization assigns different tasks to different discrete units within the organization. In an insurgent group, for example, this could mean that certain individuals would be assigned the task of disseminating propaganda exclusively, while other units would be tasked with intimidating and coercing the population in to providing support.

Specialization improves productivity and efficiency through three main mechanisms. Specialized units generally becomes more skilful at the task at hand, save time and effort by not having to move between tasks, and can develop better techniques and methods for completing the task at hand. ${ }^{212}$ All of these mechanisms are productivity enhancing, but there is also a clear element of efficiency improvement at play because more output is generally created by less input when the task is a specialized one, meaning that variable production costs are reduced. ${ }^{213}$ Hence, insurgent groups with higher levels of vertical and horizontal organizational specialization tend to be more efficient and are, as a result, more likely to be able to secure organizational growth and more likely to grow to a larger overall size.

As an organization increases in size, the opportunity cost that emerges if specialization is not adopted grows more pronounced. The opportunity cost per worker or organizational unit can plausibly increase in both absolute and relative terms. In absolute

\footnotetext{
${ }^{211}$ Gary Johns and Alan M. Saks, Organizational Behaviour: Understanding and Managing Life at Work (Toronto: Pearson/ Prentice-Hall, 2005), 449-451.

${ }^{212}$ Adam Smith, The Wealth Of Nations (New York: Oxford University Press, 1998), 15.

${ }^{213}$ James C. Dumville and Franciso A. Torano, "Division of Labor, Efficient? Empirical Evidence to Support the Argument," SAM Advanced Management Journal, Vol. 62, no. 2 (Spring 1997), 16.
} 
terms, or basically assuming that the average opportunity cost without specialization is constant, more workers or more units result in a higher total opportunity cost as the group gets bigger. In other words, larger organizations without any organizational specialization are highly inefficient. In relative terms, it is also quite possible that, in an organization without specialization, the opportunity cost per unit grows more pronounced as the organization grows in size. In this scenario, the opportunity cost per unit goes up as the group gets larger. A combination of both trajectories is probably most likely in most cases, although the former would always occur. The empirical expectation would be that large organizations should strongly tend to be specialized in order to avoid high opportunity costs in their production of output. In line with this observable expectation, research on how organizations structure themselves has consistently found a positive correlation between greater group size and the level of specialization the group is likely to have. ${ }^{214}$

Specialized organizational components need to be coordinated, controlled, and directed, in order to function coherently and result in efficiency gains. Coordination and controlled direction of organizational components is best achieved in more centralized organizations. Organizational centralization, therefore, is an essential requirement of effective organizational specialization. As Abdulkader H. Sinno notes, "Centralization is generally a necessary prerequisite for effective specialization, because the lack of central control and coordination can lead to confusion and the collapse of the differentiated

\footnotetext{
${ }^{214}$ A. Mryman, A.D. Breadsworth, E.T. Keil, and J. Ford, "Organizational Size and Specialization," Organizational Behaviour, Vol. 4, no. 3 (1983), 271-277; John Child, "Predicting and Understanding Organizational Structure," Administrative Studies Quarterly, Vol. 18, no. 2 (1973), 168-185; D.S. Pugh, D.J. Hickson, C.R. Hinings, and C. Turner, "Dimensions of Organizational Structure," Administrative Science Quarterly, Vol. 13, no. 1 (1968), 65-105.
} 
organization." ${ }^{215}$ Indeed, the efficiency benefits of organizational specialization are often a core impetus for organizational centralization. ${ }^{216}$

An insurgency that aims to developed specialized organizational features needs to have certain structures in place if the benefits of specialization are to emerge. The need to develop dedicated structural feature to obtain specialization means that a rebellion's fixed costs need to go up as it specializes its organization. For instance, effective horizontal specialization, where tasks are divided between units, requires that the different units be effectively coordinated. Effective coordination, as we saw in the last subsection, requires often costly coordination mechanisms. Similarly, a specialized organization needs to rely upon authoritative decision-makers and a functional hierarchy (vertical specialization), which is again costly for an insurgency. Finally, specialization, in its own right, imposes fixed costs onto an organization, since specialized activity requires extensive training, planning, and routinization of the task at hand before it can actually emerge. Although no research that I have found demonstrates this point one way or the other, it stands to reason that the fixed costs needed to develop sufficient organizational features to allow for specialization are greater than the fixed costs associated with maintaining a highly decentralized and unspecialized organization where every function is reproduced as every level of the insurgency.

Historical evidence again suggests that insurgent groups develop more specialized and differentiated organizational organs in order to better (more efficiently) produce

\footnotetext{
${ }^{215}$ Abdulkadar H. Sinno, Organizations at War: In Afghanistan and Beyond (Ithaca: Cornell University Press, 2008), 40.

${ }^{216}$ In the literature on organizations, this notion is a part of the "Mechanistic Model," where an organization "functions in a machinelike manner to accomplish the organization's goals in a highly efficient manner." One of the ways it does so is through organizational specialization. See, James Gibson, John Ivancevich, and James Donnelly, Organizations: Behaviours, Structures, Processes (Toronto: McGrawHill, 2006), 408.
} 
remunerative compensation and preference manipulation tactics, and thereby secure organizational growth. The evidence also suggests that groups that are growing in size tend to accommodate this growth through organizational change towards increased organizational specialization and greater centralization. During the Huk Rebellion in the Philippines, for instance, Luis Taruc, a communist party leader, later noted, "The haphazard and rather uncoordinated methods of the AMT were replaced by smoothrunning committees which had a division of labor. ... [As a result,] it was extremely easy to organize [and mobilize] the people." ${ }^{217}$ Similarly, during the 1980s and early 1990s, alJamma al-Islamiyya in Egypt changed organizationally towards a more functionally differentiated and centralized group as its popular support increased due to an extensive propaganda campaign ${ }^{218}$ and the state's use of indiscriminate repression. ${ }^{219}$ As Stefan Malthaner argues:

The group evolved organizationally. When al-Jamma reappeared in the mid-1980s, it did so in the form of small groups ... but seemed to gradually re-establish more centralized organizational structures and functional differentiation with separate branches, for example, for open political work and proselytism, for logistics and media, and the military operations. Leadership was in the hands of al-Jamaa's 'governing council' (majlis al-shura), comprising about 8-10 people. ${ }^{220}$

Likewise, Hezbollah, which began as an umbrella organization in Southern Lebanon, reformed organizationally towards higher levels of functional differentiation, with specialized branches dedicated to service provision, propaganda, and other functions, as

\footnotetext{
217 Luis Taruc, Born of the People (Westport: Greenwood Press, 1975), 218.

${ }^{218}$ Stefan Malthaner, Mobilizing the Faithful: Militant Islamist Groups and Their Constituencies (New York: Campus Verlag, 2011), 71-72.

${ }^{219}$ Mohammed M. Hafez and Quintan Wikorowicz, "Violence as Contention in the Egyptian Islamic Movement," Quintan Wiktorowicz ed., Islamic Activism: a Social Movement Theory Approach (Indianapolis: Indiana University Press, 2004), 67-71.

${ }^{220}$ Stefan Malthaner, Mobilizing the Faithful: Militant Islamist Groups and Their Constituencies (New York: Campus Verlag, 2011), 70.
} 
well as higher levels of institutional centralization. ${ }^{221}$ During the course of these reforms, popular support for Hezbollah expanded significantly as the organization reportedly grew from an estimated few hundred people in the early 1980 s to 20,000 to 30,000 group members by the mid-1990s, with, of course, Iranian money also facilitating this meteoric expansion. ${ }^{222}$

In sum, organizations that lack organizational centralization miss out on the enhanced productivity and efficiency that results from the increased organizational specialization that is made possible by this type of structure. As the historical evidence presented above suggests, groups that successfully centralize and use specialized organizational functions tend to obtain more popular support. Moreover, as organizations grow in size, the incentive to specialize a group's organizational functions tends to grow.

\subsection{7 - Agency Costs, Monitoring and Compliance Mechanisms, and Organizational} Centralization

The leadership of an organization typically relies, to a greater or lesser extent, upon its subordinates both to produce outputs and to provide information to the leadership about the subordinate unit's own behaviour and performance. ${ }^{223}$ Because organizational leadership does not always have a clear sense of what each of its agents are doing, and, therefore, cannot always distribute reward and punishment according to individual performance, each sub-unit has an incentive to pursue their own self-interest. Often, an

\footnotetext{
${ }^{221}$ On Hezbollah as an "umbrella organization," see Ibid., 82.

222 On Hezbollah's organization change and growth, see Ibid., 92.

${ }^{223}$ For a truly first-rate discussion of agency problems as they affect the organization and security of terrorist groups, see Jacob N. Shapiro, The Terrorist Dilemma: Managing Violent Covert Organizations (Princeton: Princeton University Press, 2013).
} 
individual's pursuit of self-interest occurs at the expense of organizational objectives. ${ }^{224}$

An agent's maximization of self-interest tends to manifest as defection, task-shirking, and outright appropriating or rent-seeking behaviour that is usually at variance with the goals of the organization.

Agency costs, therefore, are the "residual losses" in group performance that can result from individuals acting contrary to group goals. ${ }^{225}$ As a group's monitoring and control mechanisms weaken and more pronounced information asymmetries between a group's leadership and its membership emerge, agency costs tend to increase because more organizational sub-units pursue parochial self-interest, both pecuniary and nonpecuniary, at the expense of the organization's goals. An insurgency with pronounced agency costs is inefficient, since it needs to allocate more labour and capital to produce a given bundle of output than a rebellion with lower agency costs. Essentially, a rebel group with high agency costs has high variable production costs and is likely to be hard pressed to obtain organizational growth.

Both information asymmetries and the problem of controlling people's behaviour tend to increase as a group grows in size. Hence, agency costs tend to grow as an organization gets larger. The reason is that the clear identification of any individual's contribution (or lack thereof) to the production of outputs becomes more difficult as the

\footnotetext{
${ }^{224}$ For an analysis of the efficiency reducing effect of information asymmetries in competitive markets see, for example, George Akerlof, "The Market for 'Lemons': Qualitative Uncertainty and the Market Mechanisms," Quarterly Journal of Economics, Vol. 84, no. 3 (1970), 488-500. For an application of information asymmetry and the principal-agent problem as it applies to firms see, for example, Canice Prendergast, "The Provision of Incentives in Firms," Journal of Economic Literature, Vol. 37, no. 1 (1999), 7-63.

${ }^{225}$ This conceptualization of agency costs is adapted from Michael C. Jensen and William H. Meckling, "Theory of the Firm: Managerial Behavior, Agency Costs and Ownership Structure," Journal of Financial Economics, Vol. 3, no. 4 (1976), 308. Jensen and Meckling include monitoring costs and residual costs as part of agency costs and also include "bonding costs" as part of agency costs, which is something akin to granting bonds in a company.
} 
number of people involved rises. As the organization's ability to identify each individual's marginal contribution to a finished product declines, each person's actual contribution tends to fall as well. This process is commonly known as "social loafing,"226 although if the product produced is a public good it could also be called "free-riding". ${ }^{227}$ One study of individual contributions to menial tasks such as shouting and clapping, for instance, found that, when working in groups, people tend to produce less output. For example, one study found that two individuals produced only 71 percent of their collective potential, that is, 71 percent of the summed total of their maximum individual output, when working as a group. Basically, one or both individuals were working a total of 31 percent less hard because of the presence of another worker and a collectively produced and measured outcome. The same study also found that the effect grew more pronounced as the group size increased, so that, for example, a group of four individuals produced at only 51 percent of their maximum individually produced output, while a group of six individuals produced at only 40 percent of the summed individual effort. ${ }^{228}$ Indeed, another meta-analytical review of the phenomenon of social loafing found that its occurrence was fairly "generalizable across tasks and subject population."229 Basically, identifying any individual's particular contribution to a collectively produced product is harder in bigger organizations, because the information asymmetries and compliance

\footnotetext{
${ }^{226}$ Bibb Latane, Kipling Williams, and Stephen Harkins, "Many Hands Make Light the Work: The Causes and Consequences of Social Loafing," Journal of Personality and Social Psychology, Vol. 37, no. 6 (1979), 822-832; Steven J. Karau and Kipling D. Williams, "Social Loafing: A Meta-Analytical Review and Theoretical Integration," Journal of Personality and Social Psychology, Vol. 65, no. 4 (1993), 681-706. ${ }^{227}$ Mancur Olsen, The Logic of Collective Action: Public Goods and the Theory of Groups (Cambridge: Harvard University Press, 1971).

${ }^{228}$ Bibb Latane, Kipling Williams, and Stephen Harkins, "Many Hands Make Light the Work: The Causes and Consequences of Social Loafing," Journal of Personality and Social Psychology, Vol. 37, no. 6 (1979), 824.

${ }^{229}$ Steven J. Karau and Kipling D. Williams, "Social Loafing: A Meta-Analytical Review and Theoretical Integration," Journal of Personality and Social Psychology, Vol. 65, no. 4 (1993), 681-706.
} 
problems between the leadership and the subordinates become more pronounced as the group grows in size. The more pronounced that information asymmetries and compliance problems become, the more likely it is that individuals will task-shirk, free-ride, defect, or otherwise abjure organizational goals. As a result, more agency costs get entered into the group's production relationship.

To correct for information problems, an organization can develop monitoring mechanisms that help reduce the extent of the information asymmetries between leadership and sub-units. Effective monitoring mechanisms reduce the incentive for taskshirking of all types by establishing a better interrelationship between an individual's marginal productivity and the individual's receipt of appropriate reward or punishment. Effective monitoring occurs when a specified group is tasked with "measuring output performance, apportioning rewards, observing the input behavior of inputs as means of detecting or estimating their marginal productivity and giving assignments or instructions in what to do and how to do it."1230 Thus, when a group's monitoring mechanisms improve, individual behaviour is more likely to be brought in line with organizational goals and agency costs fall.

Identifying individual behaviour that is at variance with the objectives of the organization is only the first step toward fully correcting for organizationally defective individual behaviour and thereby toward reducing an organization's agency costs. Once identified, individuals who task-shirk, defect, rent-seek, or otherwise fail to pursue organizational aims need to be compelled to behave correctly. As Amitai Etzioni notes, organizations can endeavour to enhance individual compliance with group goals through

\footnotetext{
${ }^{230}$ Armen A. Alchian and Harold Demsetz, "Production, Information Costs, and Economic Organization," The American Economic Review, vol. 62, no. 5 (1972), 782.
} 
three predominant compliance mechanisms: coercive mechanisms (based around punishment), utilitarian mechanisms (based upon rewards and their withholding), and normative mechanisms (based upon persuasion) ${ }^{231}$ Each compliance mechanism can operate in tandem to some degree, although some of the effect of each is washed out when another form is used, for example, when normative appeals are mixed with coercion. Regardless, once defective individual behaviour has been identified, a rebel group can reward good behaviour (utilitarian and normative), sanction defective behaviour (withdrawal of utilitarian and coercive), and encourage self-monitoring (normative). Rebel groups that can effectively organize effective compliance mechanisms gain a clearly enhanced level of control over the actions and behaviour of their sub-units. Control, in turn, inhibits individual defection from organizational goals and enhances group solidarity, which reduce the agency costs that a group faces. ${ }^{232}$ As agency costs fall due to effective monitoring and compliance mechanisms, moreover, the efficiency with which an insurgency can produce remunerative compensation and preference manipulation tactics increases. In the end, a group with relatively low agency costs should find it easier to obtain organizational growth over time and be able to expand to larger total size.

Effective monitoring and compliance mechanisms are an integral part of organizational centralization. ${ }^{233}$ More centralized organizations tend to have stronger monitoring mechanisms and more effective compliance mechanisms in place to identify

\footnotetext{
${ }^{231}$ Amitai Etzioni, A Comparative Analysis of Complex Organizations (New York: The Free Press, 1975), 322.

${ }^{232}$ Michael Hechter, Principles of Group Solidarity (Berkeley: University of California Press, 1988), 53.

${ }^{233}$ I use the term centralized organization to denote more unitary organizational forms that are essentially the same as the U-shaped organizations found in Patrick Johnston, "The Geography of Insurgent Organization and its Consequences for Civil Wars: Evidence from Liberia and Sierra Leone," Security Studies, Vol. 17, no. 1 (2008), 112.
} 
and reward good behaviour and to notice and sanction bad behaviour. Thus, defection, task-shirking, and free-riding or social loafing tend to be less pronounced in more centralized organizations because individual behaviour is more closely monitored and more likely to be properly rewarded or sanctioned. As these individual behaviours decline, agency costs fall and a rebel group's efficiency should rise.

In more decentralized organizations, in contrast, effective monitoring and compliance mechanisms are generally weak, which encourages individual behaviour that is at variance with organizational goals and raises the group's agency costs. As Terry Moe argues, as an organization decentralizes, "tasks and authority are delegated to lower-level units in the expectation that they will use their specialized knowledge and productive capacities to contribute toward organizational ends; but the inevitable information asymmetries create incentive problems." ${ }^{234}$ A decentralized organizational structure, then, results in individual behaviour that is often at odds with the overarching goal of the insurgent organization. Such behaviour effectively increases the agency costs that an insurgency has to absorb and reduces the group's efficiency at producing popular supportsecuring outputs.

Rebel groups that seek to minimize the agency costs that they need to absorb have to develop appropriate control and monitoring mechanisms, as was previously mentioned. Establishing these mechanisms raises an insurgency's fixed costs. Specializing some units to supervise others requires special training and indoctrination, higher wages, and monitoring of the monitors. Likewise, developing specialized control mechanisms are costly, too, since control mechanisms need to be developed, paid for, and maintained

\footnotetext{
${ }^{234}$ Terry Moe, "The New Economics of Organization," American Journal of Political Science, Vol. 28, no. 4
} (1984), 755. 
even when they may not be immediately needed. Clearly, developing these monitoring and control mechanisms is far more costly than not maintaining any mechanisms to control or monitor an organization's membership. In this case, again, to increase its efficiency an insurgency can invest in its organizational structure, which raises its fixed costs, but lowers it variable costs. If variable costs are reduced by more than the increase in fixed costs, then the rebel group's total costs decline and the rebellion should be more likely to obtain organizational growth and should be able to grow to a larger overall size.

Both the positive effect of organizational centralization on individual behaviour and the negative effect of organizational decentralization on individual behaviour and group efficiency are evident historically. Hezbollah, for example, leverages its fairly centralized organizational form to closely monitor and sanction its membership using normative mechanisms in order to ensure that task-shirking, free-riding, and outright defection do not often occur. ${ }^{235}$ For instance, the individual members of Hezbollah who are tasked with providing services to the families of "martyrs" are a "part of a strict hierarchy, and neglecting their duties may lead to them being discharged, which is a punishment inflicted mainly through shame and ostracism from the individual's social environment." ${ }^{236}$ Likewise, in Liberia, LURD rebels maintained a centralized organizational form, with fairly effective monitoring and compliance mechanisms. As a result, "Agents [members of the rebel group] could not easily hide or misrepresent information from commanders because of the elites' immediate presence. Subordinates whose status in the organization might have otherwise led them to prefer defection had to

\footnotetext{
${ }^{235}$ Hizbollah also uses other compliance mechanism to be sure, but a lot of their internal cohesion seems to be generated by normative mechanisms.

${ }^{236}$ Stefan Malthaner, Mobilizing the Faithful: Militant Islamist Groups and Their Constituencies (New York: Campus Verlag, 2011), 228.
} 
weigh the potential costs of reprisal when making strategic choices. More often than not, LURD mid- and low-level personnel followed organizational directives." ${ }^{237}$ Likewise, the FARC in Colombia is a highly centralized organization that strongly inhibits defection from organizational tasks through the use of predominantly coercive mechanisms with limited normative appeals. ${ }^{238}$

Comparative historical evidence also suggests that more decentralized organizations have weaker monitoring and compliance mechanisms, which lead to more task-shirking, rent-seeking, and otherwise defective individual behaviour. These behaviours, in turn, increase the insurgency's agency costs. In Liberia, for example, the NPFL was a highly decentralized rebel organization led by Charles Taylor. During the early 1990s, at a high point in the group's decentralization, organizational sub-units engaged in all manner of defection, task-shirking, and rent-seeking behaviour, with many sub-groups attempting to enhance their own personal wealth rather than trying to obtain the broader objectives of the organization. ${ }^{239}$ Likewise, in Sierra Leone:

RUF elites delegated political control to town-based subcommanders. Such delegation allowed mid- and low-level agents free rein to pursue their own objectives, which often included summary executions, rape, forced labour, pillaging of civilians' possessions, burning of civilians' houses, and depriving civilians of food. ${ }^{240}$

Similarly, after some largely ineffective efforts at increased organizational centralization, the Huk insurgency in the Philippines remained fairly decentralized, particularly in areas

\footnotetext{
${ }^{237}$ Patrick Johnston, "The Geography of Insurgent Organization and its Consequences for Civil Wars: Evidence from Liberia and Sierra Leone," Security Studies, Vol. 17, no. 1 (2008), 127.

${ }^{238}$ Francisco Gutierrez Sanin and Antonio Giustozzi, "Networks and Armies: Structuring Rebellion in Colombia and Afghanistan," Studies in Conflict and Terrorism, Vol. 33, no. 9 (2010), 844-845.

${ }^{239}$ William Reno, "Foreign Firms and the Financing of Charles Taylor's NPFL," Liberian Studies Journal, Vol. 18, no. 2 (1993), 175-188, cited in, Patrick Johnston, "The Geography of Insurgent Organization and its Consequences for Civil Wars: Evidence from Liberia and Sierra Leone," Security Studies, Vol. 17, no. 1 (2008), 123.

240 Patrick Johnston, "The Geography of Insurgent Organization and its Consequences for Civil Wars: Evidence from Liberia and Sierra Leone," Security Studies, Vol. 17, no. 1 (2008), 130-131.
} 
outside of the heart of the insurgency in Central Luzon. The insurgency's fairly decentralized structure gave rise to pronounced information asymmetries and compliance problems as it tried to expand the insurgency into other provinces. In the end, the insurgency failed to expand, in large part, because the rebel agents that were sent to areas of limited insurgent influence tended to abuse their autonomy from the overarching revolutionary organization by extorting the population for personal gain. ${ }^{241}$ This sort of individual behaviour raised the rebellion's agency costs and reduced the amount of remunerative compensation and preference manipulation tactics that could be produced in the new areas, which, in turn, limited the amount of popular support the insurgency received. Likewise, the Taliban in the current Afghan conflict experience high agency costs, as "the decentralized nature of the movement makes it difficult to maintain a very strict discipline; all the leadership can do is to punish culprits from time to time, hoping to contain degenerative tendencies. ${ }^{242}$ In Aceh, the GAM insurgency decentralized command and control prerogatives to lower organizational levels. As a result, "actions carried out for hard-line ideological reasons or indeed for purely economic gain of individuals, cells, or factions are sometimes at odds with directives of the top leadership." ${ }^{243}$ The result of these actions is higher agency costs and a residual loss in the productive efficiency of the insurgency.

As these examples illustrate, more centralized rebel organizations tend to have better monitoring and compliance mechanisms that reduce task-shirking, rent-seeking,

\footnotetext{
${ }^{241}$ Benedict J. Kerkvliet, The Huk Rebellion: a Study of Peasant Revolt in the Philippines (New York: Rowman \& Littlefield Publishers, Inc., 2002), 235-236.

${ }^{242}$ Francisco Gutierrez Sanin and Antonio Giustozzi, "Networks and Armies: Structuring Rebellion in Colombia and Afghanistan," Studies in Conflict and Terrorism, Vol. 33, no. 9 (2010), 843.

${ }^{243}$ Kirsten E. Schulze, "The Free Aceh Movement (GAM): Anatomy of a Separatist Organization," (Washington: East-West Center, 2004), 12-13.
} 
and otherwise defective individual behaviour. As organizational mechanisms correct for these activities, a group's agency costs decline and the efficiency of the insurgency's production of remunerative compensation and preference manipulation tactics increases. More decentralized insurgent organizations, in contrast, face fairly pronounced information asymmetries and compliance problems due to generally weaker corrective organizational mechanisms. The result is a higher level of task-shirking, defection, and rent-seeking behaviour on the part of organizational members, which raises the agency costs of decentralized rebel groups. As with the other elements of organizational centralization, investing in control and monitoring mechanisms raises the group's fixed costs but lowers its variable costs. If the increase in fixed costs is less than the decrease in the group's variable costs, its total costs fall and the group is now more likely to obtain organizational growth.

\subsection{8 - Some General Relationships: Organizational Centralization, Group Size, and Group Productive Efficiency}

As the last four subsections have highlighted, specific component characteristics of organizational centralization can reduce a group's decision-making costs, coordination costs, opportunity costs, and agency costs. The beneficial effect of organizational centralization on rebel group production is not unending, however, as diminishing marginal returns and defects related to the core characteristics of centralization create their own costs that can then impede production. Hence, the efficiency enhancing characteristics of organizational centralization initially increase quite quickly, but taper off at a rapid pace once a high level of centralization is reached. Eventually, the marginal returns to further centralization approach zero. 
Moreover, it is quite possible that over-centralization could actually cause positive harm to an organization's production efficiency at some exceedingly high level. In such a case, the relationship between organizational centralization and efficiency gains would look like a inverted-U, initially rising as centralization increases and then declining as centralization becomes a burden rather than a benefit. At the very least, the diminishing effects of additional centralization shows that maximal levels of organizational centralization are not necessarily the best organizational objective of an insurgent group, but that centralization is generally of positive benefit to an insurgent group's productive efficiency. The implication of this analysis is that rebel groups that are attempting to secure enough popular support to ensure positive organizational growth may face a strong incentive to centralize their organization so as to produce outputs more efficiently.

The size of an insurgent group also has an effect on a group's productive efficiency, by again affecting the group's decision-making, coordination, opportunity, and agency costs. Each of these costs tends to increase as a rebel group grows in size. The positive relationship between size and production costs, and hence the negative relationship between size and group productive efficiency, is particularly pronounced in a group with unresolved organizational problems and limited centralization. ${ }^{244}$ As a result, it is reasonable to expect that a group that is growing larger may face an increasing incentive to centralize organizationally in order to correct for underlying organizational defects and to ensure that group inefficiency does not erode the group's production of outputs. As Peter Blau and W. Richard Scott put it, "The larger the group and the more

\footnotetext{
${ }^{244}$ Richard Z. Gooding and John Wagner III, "A Meta-Analytic Review of the Relationship between Size and Performance: The Productivity and Efficiency of Organizations and their Subunits," Administrative Science Quarterly, Vol. 30, no. 4 (1985), 462-481.
} 
complex the task it seeks to accomplish, the greater are the pressures to becomes explicitly organized. ... In an organization that has been formally established, a specialized administrative staff usually exists that is responsible for maintaining the organization as a going concern and for coordinating the activities of it members. Large and complex organizations require an especially elaborate administrative apparatus."245 In short, larger groups tend to become more centralized. ${ }^{246}$ The basic implication here is that the variance in insurgent group organizational forms should decrease as the groups in question grow size, with each adopting the component characteristics of organizational centralization. ${ }^{247}$ Empirical support for this proposition involving a sample of insurgent groups is found in chapter 5 .

As an organization increases in size, the various costs that can be introduced into the production process due to unresolved organizational deficiencies rise at an exponential rate. The implication of this association is that a group that is currently growing, but that has a certain level of defective organizational characteristics, might eventually reach an absolute size that results in either stagnation or even an outright loss of total output production. Moreover, given the underlying exchange relationship at work, an insurgent group that fails to increase its production of remunerative compensation and preference manipulation tactics will not be able to gain any more popular support above

\footnotetext{
${ }^{245}$ Peter M. Blau and W. Richard Scott, Formal Organizations: A Comparative Approach (Stanford: Stanford University Press, 2003), 7.

${ }^{246}$ Child finds, for example, that organizations do tend to become more bureaucratized as they grow in size. Bureaucratization and centralization, as I have conceptualized it, are very similar processes. See, John Child, "Predicting and Understanding Organizational Structure," Administrative Studies Quarterly, Vol. 18, no. 2 (1973), 168-185.

${ }^{247}$ In the literature on new institutionalism, this process is known as institutional isomorphism. See Paul J. DiMaggio and Walter W. Powell, "The Iron Cage Revisited: Institutional Isomorphism and Collective Rationality in Organizational Fields," American Sociological Review, Vol. 48, no. 2 (April 1983), 147-160. For an application of this principle to terrorist organizations, see Scott Helfstein, "Governance of Terror: New Institutionalism and the Evolution of Terrorist Organizations," Public Administration Review, Vol. 69, no. 4 (2009), 727-739.
} 
its current levels, assuming that the state's behaviour is constant, so many insurgent groups might hit an absolute size that necessitates either the stagnation of growth or reform towards increased levels of organizational centralization.

\subsection{9 - Conclusions}

Overall, I have argued in section 3.3 that organizational defects - namely, low levels of hierarchy, weak coordination mechanisms, low organizational specialization, and weak monitoring and compliance mechanisms - generate several costs that can reduce the production efficiency of insurgent groups. As a consequence, poor organization reduces the efficiency with which remunerative compensation and preference manipulation tactics can be produced by a rebel group and inhibits the organization's ability to grow over time and reach a large overall size.

I argued further that higher production process costs were negatively related with increased organizational centralization, proxied by hierarchy, coordination mechanisms, organizational specialization, and monitoring and compliance mechanisms. The implication of this interrelationship between costs and organizational structure is that a rebel group that is attempting to increase the efficiency of its production of outputs in order to secure more popular support may need to adopt some of the characteristics of organizational centralization. Crucially, as I have reiterated again and again in this chapter, what matters is whether the increase in fixed costs needed to develop more centralized organizational processes goes up less than the decrease in the variable costs that emerge due to more efficient production practices. If they do, then the rebellion's total costs decline and it is far more likely to obtain organizational growth. Additionally, 
I outlined how each of the four types of production process costs was exacerbated by increased organizational size.

\section{4 - Conclusions}

To illustrate how an insurgency can obtain organizational growth over time, I presented a simple profit margin model. This model formalizes how the willingness of the population to support an insurgency and the insurgency's production of popular support-securing outputs interact to determine whether or not an insurgency is mobilizing more popular support over time. The mobilization context of the insurgency determines how much the population is willing to pay in exchange for a given quantity of remunerative compensation and preference manipulation tactics. To produce output, an insurgency needs to pay two types of costs: fixed costs and variable costs. Fixed costs are the costs that need to be paid up front in order to establish and maintain an organizational and administrative presence in and around the population. Variable costs are a composite of both the raw materials used in the production of output (labour and capital) and the inefficiency of the production process.

I advanced the idea that there are two ways in which an insurgency that is currently not growing can obtain organizational growth over time. First, an insurgency can invest in expanding the scale of its administrative presence. Such an investment raises the rebel group's fixed costs, but also increases the quantity of output that the group can produce. The expansion of a rebel group's administrative presence can be accomplished through some combination of incorporating pre-existing socio-political organizations and wholly-original organization building. 
The second pathway to organizational growth for an insurgency that is currently not expanding is to invest in centralizing its organizational structure to make its production of popular support-securing output more efficient. Centralized organization costs more to maintain than decentralized organizational forms, so a rebel group's investment to improve its efficiency raises its fixed costs but lowers its variable production costs. If the decrease in variable costs is greater than the increase in the group's fixed costs, then the insurgency's total costs fall and the group is more likely to obtain organizational growth over time and more likely to grow to a large overall size. My focus of this chapter ignored, for the moment, the interaction between the state and the rebellion. The purpose of this chapter is to show that an insurgency that needs to become stronger over time, but that is not yet growing, faces an incentive to expand its administrative presence and centralize its organizational structure. In the next chapter, I consider how adopting these structural characteristics affects the interaction between the state and the insurgency. 


\section{Chapter 4: The Interaction of the State and the Insurgency}

In Chapter 2, I developed a model that showed how popular support for a rebel group is obtained through an exchange relationship. In this process, an insurgency demands a certain quantity of active and passive support from the population. To get its required level of popular support, a rebel group provides remunerative compensation to the people and uses preference manipulation tactics to affect the preference of the population in a favourable direction. A rebel group might need a certain amount of popular support in order to win, but, as the model suggests, it is not always able to mobilize that much support in a given period. In Chapter 3, I outlined how an insurgent group's efforts to mobilize enough popular support to effectively challenge the regime can necessitate both an expansion of the rebel group's administrative presence and the centralization of the group's organizational structure. In both of these chapters, I focused only on the relationship that exists between the insurgency and the population, while excluding any consideration of the interaction between the rebellion and the state.

Focusing only on the relationship between the population and an insurgency means that I left aside all the connections that exist between how an insurgency organizes both structurally and administratively and the actions of the regime's forces. In and of itself, focusing only on the internal organizational and administrative characteristics of an insurgent group and its relationship with the population is highly problematic, as clandestine groups usually need to balance group efficiency with group security. ${ }^{248}$ In the case of an insurgent group that is attempting to obtain a sufficient amount of popular

\footnotetext{
${ }^{248}$ Carlo Morselli, Cynthia Giguere, and Katia Petit, "The Efficiency/Security Trade-off in Criminal Networks," Social Networks, Vol. 29, no. 1 (2007), 143-153; Jacob N. Shapiro, The Terrorist Dilemma: Managing Violent Covert Organizations (Princeton: Princeton University Press, 2013).
} 
support through an exchange relationship so as to effectively challenge the state, the presence of a trade-off between group efficiency and group security raises two questions that I address in this chapter:

1. How does the scale of an insurgent group's administrative presence affect its vulnerability to state military activity?

2. How does the degree of an insurgency's organizational centralization affect its resiliency to state military action?

In response to the first question - How does the scale of an insurgent group's administrative presence affect its vulnerability to state military activity? - I argue that an increase in the scale of an insurgent group's administrative presence causes an increase in a rebel group's vulnerability to state military activity. Vulnerability, in this context, means that an insurgency with a larger administrative presence is more likely to be effectively targeted by counterinsurgent military forces than an insurgency with a smaller administrative presence. A rebel group's vulnerability to state military activity increases as the scale of its administrative presence expands because it gains fixed assets and responsibilities, which limit the group's mobility, which make it easier to target militarily. Similarly, the contrast between an insurgent group's organization and infrastructure and the surrounding population becomes more pronounced as its administrative presence grows in scale, making the insurgency a more visible target. Via these two mechanisms lost mobility and heightened contrast - an expanding rebel group administrative presence makes the group more vulnerable to state military activity. The extent to which a rebel group's vulnerability is increased by an expanding administrative presence is conditioned by the relative strength of the insurgency and the state within the area of expansion. 
When a rebellion is stronger than the state, it can deter regime activity, which means that the odds that the rebellion will be effectively targeted by the state are less pronounced compared to a relatively weaker insurgency.

In response to the second question - How does the degree of an insurgency's organizational centralization affect its resiliency to state military action? - I argue that a rebel group's organizational centralization and its resilience to state military activity are inversely related. As an insurgency's centralization rises, its organizational resilience goes down. Conversely, as a rebellion's level of centralization declines, its resilience to state military activity goes up, everything else being equal. A group's resilience denotes its ability to absorb being targeted militarily by the state, which includes more focused targeting like leadership decapitation as well as more broad-based military pressure. Centralized rebel groups are less resilient in the face of state military pressure than decentralized groups because the subunits of a centralized organization have a high degree of mutual reliance. This mutual reliance increases the efficiency of the rebel group, but is itself sensitive to being disrupted by state military activity. When a group's mutual reliance is disrupted to a sufficient degree, centralized rebel groups can collapse due to emergent organizational incoherence. Decentralized groups, in contrast, have far lower levels of mutual reliance between their organizational subunits, meaning their subunits are fairly autonomous from one another. While this reduces the efficiency of the group, it also entails that the collapse or destruction of any given part of a decentralized insurgency has little appreciable effect on the other segments of the revolution, making the group as a whole more organizationally resilient. The overall level of resilience that a rebel group has in the face of a given amount of state military pressure is also conditional 
upon the relative strength of the insurgency, with a rebellion that is relatively stronger than the state being more resilient than a rebel group that is weaker than the state, everything else being equal.

\section{1 - How does the scale of an insurgent group's administrative presence affect its vulnerability to state action?}

In this section, I outline how the scale of an insurgent group's administrative presence affects its vulnerability to state military activity. I define vulnerability as the ease with which a state can effectively target a rebel group. I argue, in particular, that a rebel group becomes more vulnerable to state military activity as its administrative presence expands in scale, although how pronounced that vulnerability becomes depends upon the capacity of the insurgency relative to the regime.

A larger insurgent group administrative presence entails two core sources of heightened vulnerability to state military activity: increased immobility and heightened contrast. Typically, an insurgency loses its tactical mobility and fluidity as its administrative presence grows for two reasons. First, as its administrative presence grows, a rebel group gains more fixed assets, infrastructure, and organization, which are easier for the state to target and destroy with military means. Second, an insurgent group often assumes more responsibility for the population as its administrative presence expands and displaces the state (or some other political authority) in a given area. Such heightened responsibility can compel an insurgency to stay and defend the population from counterinsurgent reprisals, again limiting the rebellion's mobility and increasing the odds that the state can effectively target the insurgent group. A larger rebel group administrative presence also increases the contrast between the surrounding population 
and an insurgency's infrastructure and organization, which means the group stands out from the people in more detail. In turn, a greater contrast between the surrounding population and a rebellion's organization and infrastructure makes the group more vulnerable to identification and targeting by state forces. Below, I explore each of these mechanisms in turn. I present various historical examples throughout the analysis to substantiate the claims that are made.

\subsection{1 - Administrative Presence and Rebel Group Mobility}

Mobility is one of the key qualitative military advantages that an insurgency possesses over the forces of the regime. By mobility, I mean an insurgency's fluidity and its ability to avoid points of counterinsurgent strength while targeting points of counterinsurgent weakness. As T.E. Lawrence puts it, rebels must remain "an influence, an idea, a thing intangible, invulnerable, without front or back, drifting about like a gas. [Counterinsurgent] armies [are] like plants, immobile, firm-rooted, nourished through long stems to the head. ... A regular soldier might be helpless without a target, owning only what he sat on, and subjugating only what, by order, he could poke his rifle at."249 Likewise, Ho Chi Minh, the political leader of the Vietminh, describes mobility and insurgency thusly:

If the tiger [the insurgent] ever stands still, the elephant [the counterinsurgent] will crush him with his mighty tusks. But the tiger will not stand still. He will leap upon the back of the elephant, tearing huge chunks from his side, and then he will leap back in the dark jungle. And slowly the elephant will bleed to death. Such will be the war in Indochina. ${ }^{250}$

\footnotetext{
249 T.E. Lawrence, Seven Pillars of Wisdom (London: Vintage Classics, 2008), 198.

${ }^{250}$ Ho Chi Minh, cited in, Wilbur H. Morrison, The Elephant \& the Tiger: The Full Story of the Vietnam War (New York: Hippocrene Books, 1990), 14.
} 
As its mobility is reduced, an insurgency becomes vulnerable to attack by the typically more powerful forces of the counterinsurgency. Two aspects of its growing administrative presence can impede the mobility of an insurgency: growing fixed assets and increased responsibility for the people. The fixed assets, infrastructure, and organization that compose an insurgency's administrative presence go up as the scale of its administrative presence increases. Typically, these assets are less mobile than insurgent forces whose sole purpose is hit-and-run guerrilla warfare. As a result, an insurgency erodes its mobility by developing fixed assets as it increases the scale of its administrative presence. As a rebel group's mobility declines, the odds increase that a counterinsurgency can successfully target the rebellion with military force.

Evidence suggests that as an insurgency expands its administrative presence, it displaces the state and develops largely immobile assets, infrastructure, and organizational structures. ${ }^{251}$ In Eritrea, for example, "inserting the EPLF's administrative structures into the village not only aimed at transforming internal village social, economic and political relations but also at breaking the connection [of the community] to the Ethiopian state." 252 In Peru, the Shining Path expelled the vestiges of state authority from much of the countryside as it expanded into the northern highlands, such that, "by 1990, about 80 percent of the rural districts of San Marcos, Cajabamba, Huamachuco and Santiago de Chuco lacked lieutenant governors, justices of the peace, land judges and other low-ranking authorities." ${ }^{253}$ In their place, the Shining Path set up

\footnotetext{
${ }^{251}$ Alexus G. Grynkewich, "Welfare as Warfare: How Violent Non-State Groups Use Social Services to Attack the State," Studies in Conflict and Terrorism, Vol. 31, no. 4 (2008), 350-370.

${ }^{252}$ David Pool, From Guerrillas to Government: The Eritrean People's Liberation Front (Athens: Ohio University Press, 2001), 118.

${ }^{253}$ Lewis Taylor, Shining Path: Guerrilla War in Peru's Northern Highlands, 1980-1997 (Liverpool: Liverpool University Press, 2006), 105.
} 
"popular committees" to govern the area and mobilize popular support. ${ }^{254}$ Likewise, in Algeria, "it was the primary duty of the OPA cells [of the FLN insurgency] to undermine the French administration at every level, gradually replacing it with officials and institutions of the revolutionary party." ${ }^{255}$ In Vietnam, Vietcong "coercion and terror were employed primarily to immobilize the GVN [Government of Vietnam's] structure, drive it from the countryside, and replace it with the Front's infrastructure. ${ }^{256}$ Insurgent groups across time and across contexts displace the regime in a given area and replace the vestiges of the state with their own assets, infrastructure and organizational structures. In turn, these fixed assets hinder the mobility of a rebel group to varying degrees, making the insurgency easier to target by state forces.

Insurgent groups also suffer from reduced mobility as their responsibility for the population increases. Once the population becomes beholden to an insurgency, it is more difficult for a rebel group to simply flee in the face of counterinsurgent military activity and abandon the population to the machinations of the state. To do so risks engendering significant and potentially long-lasting popular resentment and backlash against the rebellion. As Timothy Wickham-Crowley puts it, "When guerrillas do become the legitimate regional authorities in the areas they control, they must assume the obligations thereof. Failure to defend the populace may be grounds for loss of such authority." ${ }^{257}$ As the insurgency expands its administrative presence, it displaces the state, leaving an authority vacuum that the rebel group attempts to fill. Rebel groups that are very

\footnotetext{
${ }^{254}$ Simon Strong, Shining Path: Terror and Revolution in Peru (New York: Times Books, 1992), 87.

${ }^{255}$ Alf Andrew Heggoy, Insurgency and Counterinsurgency in Algeria (Bloomington: Indianapolis University Press, 1972), 120.

${ }^{256}$ Richard Shultz, "Breaking the Will of the Enemy During the Vietnam War: The Operationalization of the Cost-Benefit Model of Counterinsurgency Warfare," Journal of Peace Research, Vol. 15, no 2 (1978), 115.

${ }^{257}$ Timothy P. Wickham-Crowley, "The Rise (And Sometimes Fall) of Guerrilla Governments in Latin America," Sociological Forum, Vol. 2, no. 3 (Summer 1987), 492.
} 
successful at displacing the state also become quite responsible for the population and cannot simply flee when and if the state re-asserts itself in an area.

Historical examples support the idea that insurgents assume responsibility for the population as their administrative presence displaces that of the state and that ignoring this duty can generate grassroots resentment, making further popular mobilization more difficult by souring the population's preferences towards the rebellion. During the Shining Path insurgency in Peru, for example, "Peasant support for Sendero was eroded ... when cadres failed to honour their promise to stay and protect villagers following the armed forces' saturation of the countryside in 1983." ${ }^{258}$ In Eritrea, the EPLF recognized that they held responsibility for the population of the numerous urban centres that they had assumed control of between 1974 and 1977. When a Derg offensive in 1978 forced the EPLF to withdraw from the towns and cities, the insurgency was able to avoid unwanted popular backlash by, in an extraordinary feat of organization and planning, taking the population with them as they withdrew to more secure base areas in the Sahel. As Dan Connell puts it, "by effecting the withdrawals methodically and by giving the civilian population assistance with evacuation, the EPLF retained its core military strength and population support." ${ }^{259}$ During a Philippine government offensive in March 1975 , driven by a sense of responsibility for the population, "an entire detachment of guerrillas left behind in Aurora to defend a few hundred communist civilian supporters who chose to stay in the province was killed, and about 100 civilian supporters died."260

\footnotetext{
258 Lewis Taylor, Shining Path: Guerrilla War in Peru's Northern Highlands, 1980-1997 (Liverpool: Liverpool University Press, 2006), 25.

259 Dan Connell, Against All Odds: A Chronicle of the Eritrean Revolution (Lawrenceville: Red Sea Press, 1997), 166.

${ }^{260}$ Gregg R. Jones, Red Revolution: Inside the Philippine Guerrilla Movement (Boulder: Westview Press, 1989), 55.
} 
An insurgency, then, sacrifices some degree of its mobility as its administrative presence expands because the group gains more fixed assets and increased responsibilities. Framed from the opposite direction, an insurgency, as Lieutenant Colonel David Galula puts it, "is fluid [only] because [it] has neither responsibility nor concrete assets. ${ }^{261}$ In the end, an expanded insurgent group administrative presence results in less rebel group mobility. A decline in mobility, in turn, increases the chances that the forces of the counterinsurgency can effectively target the insurgency with military means, making the rebellion more vulnerable to state military activity.

The Chinese Communist Party's (CCP) fateful expansion into Kiangsi in the early 1930s is a premier example of how a growth in an insurgent group's administrative presence impedes its mobility through greater fixed assets and heightened responsibility. ${ }^{262}$ By 1934, the CCP had "administrative control of much of Kiangsi," making it a secure revolutionary base area. ${ }^{263}$ In response, the Kuomintang forces initiated a series of 'annihilation campaigns' to destroy the Communist administrative bases throughout the area. The fifth 'annihilation campaign' was launched in 1934. This campaign nearly defeated the CCP insurgency and gave rise to the famous 'Long March'. The Kuomintang counterinsurgents marshalled some 900,000 troops for their attack, with around 400,000 taking direct part in the offensive. The Red Army fielded around 180,000 men and approximately 200,000 partisans, although these forces were seriously

\footnotetext{
${ }^{261}$ David Galula, Counterinsurgency Warfare: Theory and Practice (Westport: Praeger Security International, 2006), 7. Emphasis added.

${ }^{262}$ For a full discussion of this period, see Ilpyong J. Kim, The Politics of Chinese Communism: Kiangsi Under the Soviets (Berkeley: University of California Press, 1973).

${ }^{263}$ Wilbur W. Dinegar, "The 'Long March' As Extended Guerrilla Warfare," in Franklin Mark Osanka ed., Modern Guerrilla Warfare (New York: The Free Press, 1967), 147.
} 
underequipped and lacked much in the way of basic armaments. ${ }^{264}$ More than 80,000 Red Army soldiers had been lost by August of $1934 .^{265}$ As the counterinsurgent forces methodically advanced, the insurgency became increasingly desperate until it eventually abandoned its administrative base area in Kiangsi, narrowly escaping the forces of the Kuomintang, and began the Long March to Yenan.

The Red Army's defeat and the near destruction of the eventually victorious CCP in 1934 was the result of two factors that interacted to the advantage of the Kuomintang counterinsurgents. First, the Red Army was weaker than the counterinsurgent forces, making positional battles and conventional warfare a poor choice for the insurgency. Second, the administrative presence that the CCP had developed in Kiangsi limited the mobility and fluidity of the Red Army because of fixed assets and an enlarged responsibility for the local population. Mao's own position, as Tetsuya Katoka characterises it, was that "the cause of the CCP's defeat in Kiangsi ... was due primarily to the numerical inferiority of the Red Army." Yet, the CCP was vulnerable in Kiangsi because:

The Red Army was hemmed into an area and was compelled to engage in positional warfare for several reasons. The regular army was mobile and could break out of the encirclement. But the soviet bases were stationary. Without the rest and replenishment provided by the bases, the Red Army could not fight a protracted war. At the same time, the support of the peasant masses for the Red Army depended in the last analysis on the degree of protection provided by it. ${ }^{266}$

As this expanded example illustrates, the CCP's development of a large-scale administrative presence in the Kiangsi area resulted in a loss of mobility due to the

\footnotetext{
${ }^{264}$ Edgar Snow, Red Star Over China (Harmondsworth: Penguin Books, 1972), 214-215.

${ }^{265}$ Wilbur W. Dinegar, "The 'Long March' As Extended Guerrilla Warfare," in Franklin Mark Osanka ed., Modern Guerrilla Warfare (New York: The Free Press, 1967), 149.

${ }^{266}$ Tetsuya Kataoka, Resistance and Revolution in China: The Communists and the Second United Front (Berkeley: University of California Press, 1974), 144. Both emphasises added.
} 
stationary nature of the rebel group's administrative organs and the insurgency's responsibility for the population. The loss of mobility experienced in Kiangsi very nearly led to the early defeat of the eventually victorious Chinese communist insurgency.

In sum, an expanding rebel group administrative presence can increase the vulnerability of an insurgency to state military activity by reducing its mobility, which is a core qualitative military asset of materially weaker guerrilla fighters.

\subsection{2 - Administrative Presence and the Contrast Between the Population and a Rebel Group's Organization and Infrastructure}

Another qualitative military advantage that an insurgency has over the forces of the state is that it is usually very difficult for the counterinsurgency to identify and to target the administrative organs of an insurgent group, including its formal organization, membership, and productive infrastructure. Without clear targets for military action, the state's typically greater material resources are far less effective. Elements of an insurgency's organization and administrative infrastructure are typically hard to target because they blend in with the surrounding population, creating what Stathis N. Kalyvas calls an "identification problem." 267 As David Galula puts it, "The destruction of the insurgent forces requires that they be localized and immediately encircled. But they are [often] too small to be spotted easily by the counterinsurgent's direct means of observation." ${ }^{268}$ Likewise, Lieutenant Colonel Roger Trinquier, notes that, "To carry out a war effectively, to win it, it is indispensable to identify the adversary exactly. This condition must be fulfilled so that our shots will strike home. ... [But,] in modern

\footnotetext{
${ }^{267}$ Stathis N. Kalyvas, The Logic of Violence in Civil War (New York: Cambridge University Press, 2009), 8991.

${ }^{268}$ David Galula, Counterinsurgency Warfare: Theory and Practice (Westport: Praeger Security International, 2006), 50.
} 
warfare, the enemy is ... difficult to identify," largely because there are often very blurry lines between the population and the organization of the insurgency. ${ }^{269}$ Indeed, Trinquier goes further to state that the counterinsurgency must "attack an enemy who is invisible, fluid, and uncatchable..$^{270}$ Essentially, a clear part of the reason why insurgents are hard to counter is because they are usually hard to identify.

Most insurgent groups begin with a small-scale administrative presence that is fairly clandestine, meaning that it does not contrast overly much with the surrounding population. As the scale of an insurgency's administrative presence increases, the contrast between the surrounding population and the group's administrative organization and infrastructure grows more pronounced. Put another way, the greater the scale of an insurgency's administrative presence, the more the group's organization and infrastructure stands out in greater relief from the surrounding population. The increased contrast between a rebel group's administrative presence and the surrounding population makes it easier for the military forces of the state to identify and target the infrastructure and organization of the insurgency. When the identification of the insurgency's administrative organs and organization becomes easier, the state can, generally speaking, launch more targeted and effective attacks against the rebellion.

The communist insurgency in Greece in the 1940s, for example, established a thin, yet broad-based administrative presence throughout much of the country in order to obtain higher levels of popular support. In the early stages of its development, the administrative presence of the communist insurgency was, as Greek Field Marshall Alexander Papagos describes it, largely an "invisible administrative hierarchy [that]

\footnotetext{
${ }^{269}$ Roger Trinquier, Modern Warfare: A French View of Counterinsurgency (Westport: Praeger Security International, 1964), 22.

${ }^{270}$ Ibid., 74.
} 
exacted subservience, concurrence or, at least, non-resistance [i.e., both active and passive popular support] from the inhabitants of a considerable number of villages."271 Later on in the conflict, the Greek insurgents establish a relatively large administrative presence in the Grammos-Vitsi area in an effort to develop a secure base area from which they could support larger military units. Having increased the scale of its administrative presence in Grammos-Vitsi, the communists found that state forces began to concentrate their military efforts against this comparatively identifiable target. ${ }^{272}$

A similar pattern holds in the Philippines. In the 1970s, the CPP established a significant administrative base area in the region of Sorsogon, the smallest province of Bicol. ${ }^{273}$ In 1973, the CPP began moving the population from the surrounding area into their mountainous base. Within this area, the administrative presence of the insurgency expanded in scale, allowing the insurgency to provide economic welfare to the residents of the base area and to effectively propagandize the people. The effect on the rebel group's mobilization of popular support within the area was significant, and, "by early 1974, communist strength in Sorsogon had mushroomed from a single armed propaganda unit into a force of nearly 250 cadres and fighters." ${ }^{274}$ As the theory suggests, the CPP's large-scale administrative presence in Sorsogon attracted the attention of the state, which blockaded the region and mobilized 1,000 soldiers and additional aircraft for an offensive in the middle of 1974. By the end of 1975, the CPP forces in the region were decimated

\footnotetext{
${ }^{271}$ Field Marshall Alexander Papagos, "Guerrilla Warfare," in Franklin Mark Osanka ed., Modern Guerrilla Warfare (New York: The Free Press, 1967), 234.

272 Ibid., 237-239.

${ }^{273}$ This account is based upon the one found in Gregg R. Jones, Red Revolution: Inside the Philippines Guerrilla Movement (Boulder: Westview Press, 1989), 98-100.

${ }^{274}$ Ibid., 99.
} 
and the rebel group administrative structure was demolished. Indeed, "only 10 of the once formidable force of 250 cadres and fighters remained." 275

The same pattern recurs across regions and conflicts. An expanded rebel group administrative presence leads to a heightened contrast between the insurgency and the surrounding population, which produces, in turn, a higher level of rebel group's vulnerability to state military activity. During the Eritrean revolution against Ethiopia, the EPLF established a growing administrative presence across much of contemporary Eritrea. The administrative presence remained clandestine at first, but gradually increased in scale as the conflict wore on. Eventually, after a certain scale of administrative development was reached in 1978, the Derg regime in Ethiopia launched a series of major offensives against comparatively identifiable EPLF positions. In the face of significant counterinsurgent strength, the EPLF was forced to retreat from many areas, particularly urban centres. As Dan Connell recounts, "The painstaking organizing in these towns, aimed at establishing self-rule, was undone; the people's assemblies were smashed." ${ }^{276}$ In the initial stages of the FLN insurgency in Algeria, when the administrative presence of the insurgency was still in development, the typical counterinsurgent military action was described as follows: "French forces surrounded a designated area with a cordon sanitaire, closed in, and searched all inhabitants and structures for incriminating evidence. As a rule, however, the rebels either blended into the population or slipped away in a terrain so rugged that it has been compared to the

\footnotetext{
${ }^{275}$ Ibid., 100.

${ }^{276}$ Dan Connell, Against All Odds: A Chronicle of the Eritrean Revolution (Lawrenceville: The Red Sea Press, Inc., 1997), 166.
} 
surface of the moon." ${ }^{277}$ In contrast, later on in the conflict, once the FLN's administrative presence had increased in scale, particularly in the city of Algiers, the French counterinsurgents were able to militarily target the rebellion with greater ease. ${ }^{278} \mathrm{In}$ Guinea Bissau, "The areas 'controlled' by PAIGC ... are constantly vulnerable to air strikes. Nevertheless, the party seeks to organize and administer its liberated areas, providing governmental, health, and educational services, and a modicum of economic infrastructure to revolutionize the country." ${ }^{279}$ In essence, as these examples illustrate, the contrast between the organizational and administrative organs of the insurgency and the surrounding population becomes more pronounced as the scale of a rebel group's administrative presence increases. Ultimately, the increased contrast between the population and the rebellion makes it easier for the forces of the counterinsurgency to identify and to target the insurgency with military force, although this is not to say that the state's use of force will necessarily be discriminate, only that it more easily can be.

A related intuition that helps to establish the boundaries of the proposed notion is that a calculating insurgent group should, when facing significant military pressure from state forces, attempt to scale back its administrative presence so as to increase its mobility and decrease the contrast between the surrounding population and its organization and infrastructure. Again, the Chinese communist insurgency provides a good example of this process as it occurs over time. From 1940 to 1941, the Japanese launched a massive pacification campaign against the $\mathrm{CCP}$ in Northern China. One of the main objectives of

\footnotetext{
${ }^{277}$ Alf Andrew Heggoy, Insurgency and Counterinsurgency in Algeria (Bloomington: Indianapolis University Press, 1972), 77-78. Emphasis added.

${ }^{278}$ Alf Andrew Heggoy, Insurgency and Counterinsurgency in Algeria (Bloomington: Indianapolis University Press, 1972); Alistair Horne, A Savage War of Peace: Algeria, 1954-1962 (New York: New York Review of Books, 2006), 183-207.

${ }^{279}$ Kenneth W. Grundy, Guerrilla Struggle in Africa: An Analysis and Preview (New York: Grossman Publishers, 1971), 99.
} 
this campaign was to destroy the CCP's base areas and source of material resources. ${ }^{280} \mathrm{In}$ response to the increased military pressures of the Japanese counterinsurgency, the CCP would disperse its administrative presence. "Such dispersion," notes Tetsuya Kataoka, "the stock-in-trade of the Communist partisans in hard times, was called hua-cheng weiling ('turning a whole into nothing') ... In its most extreme form, an army or a Party unit was required to reduce itself into a 'local bandit-style armed organization' .... The purpose of hua-cheng wei-ling was to conceal the army behind the mass of peasantry," making the insurgency less directly vulnerable to attack by counterinsurgent forces. ${ }^{281}$ Spatially, the FLN demonstrates the same principle in their differential development of an administrative presence across the territory of Algeria. As Alf Andrew Heggoy explains, "For security reasons, the urban participants in the revolution had nothing resembling the rural people's assemblies," meaning that the FLN's administrative presence was generally thinner in urban areas than in the rural countryside. ${ }^{282}$ As these examples highlight, under the threat of military action or in areas where counterinsurgent forces are likely strongest, rebel groups are at least somewhat calculating and they routinely try to minimize their administrative presence in order to reduce their vulnerability to counterinsurgent military activity.

4.1.3 - Some General Relationships between Rebel Group Administrative Presence, Rebel Group Vulnerability, and the Rebellion's Capacity Relative to the State

\footnotetext{
${ }^{280}$ Tetsuya Kataoka, Resistance and Revolution in China: The Communists and the Second United Front (Berkeley: University of California Press, 1974), 273.

${ }^{281}$ Ibid., 279.

282 Alf Andrew Heggoy, Insurgency and Counterinsurgency in Algeria (Bloomington: Indianapolis University Press, 1972), 129.
} 
When the state is stronger than an insurgency in a given area, the rate at which a rebel group's vulnerability increases as its administrative presence expands is typically more pronounced than when the rebellion is stronger than the state. As the administrative presence of a rebel group expands, its vulnerability increases rapidly if it is weaker than the state because the regime can attack a weaker insurgency without risking significant losses in terms of prestige, material, and personnel. Conversely, if an insurgency happens to be stronger than the state within a particular area, then the rate at which an expanding administrative presence results in heightened rebel group vulnerability is comparatively less pronounced. A rebel group's vulnerability increases at a slower rate if it is stronger than the state because it is able to deter military activity on the part of the regime by credibly promising significant and damaging reprisals against state forces. ${ }^{283}$

As outlined in Figure 4.1, the relationship between an insurgency's vulnerability to state military activity and its administrative presence is generally positive: an increase in rebel group administrative presence, $X$, results in an increase in the vulnerability of the insurgency to state military activity, Y. The generally positive relationship emerges because, as noted above, an increase in a rebel group's administrative presence both reduces the mobility of the insurgency and increases the contrast between the surrounding population and the insurgent's organization and infrastructure, both of which make the insurgency more vulnerable to state military activity. The relationship between rebel expansion and rebel vulnerability is non-linear, with the marginal contribution of an additional increase in a rebel group's administrative presence asymptotically approaching

\footnotetext{
${ }^{283}$ For one of the seminal works on deterrence theory, see Thomas C. Schelling, Arms and Influence (New Haven: Yale University Press, 1966). On deterrence theory applied to countering non-state criminal organizations, see Mark A.R. Kleiman, When Brute Force Fails: How to Have Less Crime and Less Punishment (Princeton: Princeton University Press, 2009).
} 
zero. The relationship takes on this particular shape because the continual expansion of a rebel group's administrative presence is not as helpful for the regime as an initial expansion, since, once the insurgency is fairly fixed and contrasting with the population, being more fixed and contrasting more becomes somewhat redundant.

\section{Figure 4.1. Rebel Group Administrative Presence and Group Vulnerability Conditioned by The Relative Capacity of the State and the Insurgency}

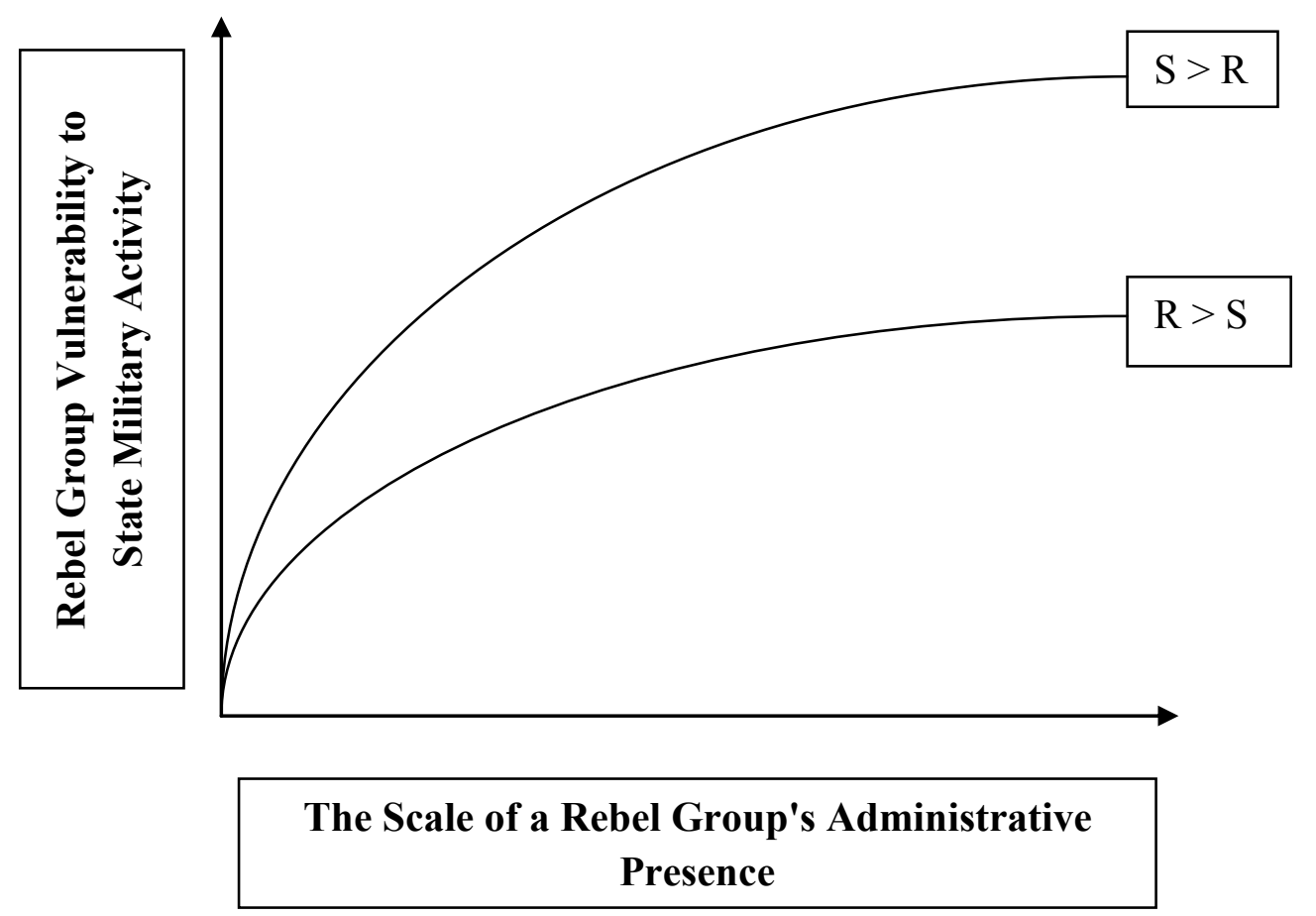

The conditional effect of relative capacity on the relationship between expanding rebel group administrative presence and the insurgency's vulnerability to state military activity emerges almost immediately, as is shown in Figure 4.1 Rebel groups that are relatively strong compared to regime forces are less vulnerable for any scale of administrative presence when compared to rebel groups that are weaker than the state. While state forces are usually stronger than an insurgency for most of a conflict at the national level, many states lack what Michael Mann has termed "infrastructural power" or 
the ability of the state to penetrate both territory and society to enforce its sovereignty. ${ }^{284}$ What this means is that some states lack the ability to control swaths of their national territory and might be unable to project considerable force levels into some areas, particularly the rough hinterlands of the countryside. ${ }^{285}$ As a result, an insurgency might well have relatively more capacity than the counterinsurgent forces of the regime in areas of weak state power. In such a situation, an expanding insurgent group administrative presence increases the vulnerability of the rebellion somewhat, as a loss of mobility and increased contrast do accrue. However, the insurgency, being relatively strong compared to the state, is capable of defending its administrative organization and productive infrastructure through positional battles against the regime, which means that it can cause a lot of damage (both material and moral) to state forces should they attempt an attack. For the state, the risk that significant costs can be imposed as a result of an attempted military action against an insurgency's administrative presence can effectively deter some of the aggression that would otherwise be forthcoming. Thus, insurgent groups that have more capacity than a regime in a localized area are less vulnerable to being targeted militarily than rebel groups that are chronically weaker than the state. Put another way, as outlined in Figure 4.1, where R (the rebellion) $>\mathrm{S}$ (the state), an expanding rebel group administrative presence in a given area is likely to result in some increased vulnerability, but the pace of the increase is likely to taper off fairly rapidly.

\footnotetext{
${ }^{284}$ Michael Mann, "The Autonomous Power of the State: Its Origins, Mechanisms and Results," Archives Européennes de Sociologie, Vol. 25 (1984), 185-213; Jeff Goodwin, No Way Out: States and Revolutionary Movements, 1945-1991 (New York: Cambridge University Press, 2003).

${ }^{285}$ On some of the factors affecting the projection of control, see Eric Jardine, "Controlling Territory and Population during Counterinsurgency: State Security Capacity and the Costs of Power Projection," Civil Wars, Vol. 14, no. 2 (2012), 228-253; James Fearon and David Laitin, "Ethnicity, Insurgency, and Civil War," The American Political Science Review, Vol. 97, no. 1 (Feb., 2003), p.75-90; Cullen S. Hendrix, "Head for the Hills? Rough Terrain, State Capacity, and Civil War Onset," Civil Wars, Vol. 13, no. 4 (2011), 345370.
} 
Relatively weak rebel groups, in contrast, are more vulnerable than stronger groups because a weak insurgency is at a clear disadvantage in terms of positional warfare when faced-off against stronger regime forces. Since a relatively weak insurgency cannot credibly cause significant material and human damage to state forces in the positional battles that are needed to defend its administrative presence, the state is less likely to be deterred from attacking the rebellion. Graphically, this process is captured by the slope of the $\mathrm{S}>\mathrm{R}$ curve. Along the $\mathrm{S}>\mathrm{R}$ curve, for every level of rebel group administrative presence, the insurgency is more vulnerable than if it was stronger than the regime, that is, along the $\mathrm{R}>\mathrm{S}$ curve.

Comparative historical evidence confirms the idea that an insurgency can deter some state encroachment into rebel-held areas if they posses enough strength to credibly harm regime forces, making it less vulnerable to being targeted. In Peru, state forces reacted to growing militant activity of the part of the Shining Path "by withdrawing to better-fortified larger stations in the largest population centers. For all intents and purposes, central-government authority gave up the Ayacucho countryside to the Shining Path in 1981 and 1982. Sendero used this unexpected opportunity to build support bases and the popular infrastructure it anticipated for its New Democracy." 286 Likewise, one Vietnamese province chief noted that, "The Vietminh had their areas, like the Plains of Reeds, which we just abandoned. Whatever the Vietminh wanted to do [in those areas], we did not bother them." 287 In rebel controlled areas in El Salvador, "The army has given up trying to maintain a fixed presence in the form of garrisons or 'civil defense' militias,

\footnotetext{
${ }^{286}$ David Scott Palmer, "The Revolutionary Terrorism of Peru's Shining Path," in Martha Crenshaw, ed., Terrorism in Context (Pennsylvania: The Pennsylvania State University Press, 2007), 293-294.

${ }^{287}$ Ho van Si, cited in, Jeffrey Race, War Comes to Long An: Revolutionary Conflict in a Vietnamese Province (Berkeley: University of California Press, 2010), 3.
} 
nor does it mount civic action programs to win over the people. Army leaders know these are pointless." ${ }^{288}$ Even against the mighty American military, Iraqi insurgents were able to repel American advances into Falluja in 2004. As a result, the city "was left more or less to its own devices, an unofficial 'free capital' of the growing Sunni insurgency." ${ }^{289}$ In sum, for any scale of rebel group administrative presence, a relatively strong insurgent group can deter state aggression, making it less likely that the insurgency will be targeted by the forces of the regime.

\subsection{4 - Conclusions}

A budding insurgency faces a core dilemma involving the growth of its administrative presence and its capacity relative to the state. On the one hand, a rebel group needs to minimize its administrative presence so as to avoid becoming too vulnerable to state military activity. At the same time, the insurgency needs to increase its administrative presence in order to reduce its average cost per unit of production, and, in turn, increase the amount of capacity augmenting popular support that it receives. A similar dilemma emerges with regards to a rebel group's organizational structure.

\section{2 - How does the degree of an insurgency's organizational centralization affect its resiliency to state military action?}

In this section, I consider how the degree of a rebel group's organizational centralization affects its resilience in the face of effective state military activity. I define rebel group resilience as the ability of an organization to absorb being effectively targeted by state military activity. A more resilient rebel group can withstand more intense state military

\footnotetext{
288 Jon Lee Anderson, Guerrillas: Journeys in the Insurgent World (New York: Penguin Books, 2004), 136.

289 Jason Burke, The 9/11 Wars (New York: Penguin Books, 2011), 132.
} 
activity while continuing to function when compared to a less resilient group. A group's lack of resilience can manifest in three non-exclusive ways: outright group disintegration (destruction), a decline in the amount of guerrilla activity, and a decline in the quality of guerrilla activity. ${ }^{290}$

Typically, as I argue below, more centralized rebel groups - or those organizations that are more efficient at obtaining popular support through the production of remunerative compensation and preference manipulation tactics - also tend to be less resilient to military attack by state forces because their subunits are generally mutually reliant. Disruptions of this mutual reliance between subunits can severely undermine a centralized group's ability to function, even to the point that the group fragments or collapses outright. In contrast, decentralized groups tend to be more resilient because their subunits are fairly autonomous from one another and do not rely upon each other to any great degree. In other words, a decentralized group's subunits exhibit low levels of mutual reliance. As with the relationship between a rebel group's administrative presence and the group's vulnerability, the relationship between insurgent group organizational structure and group resilience is conditional upon the capacity of an insurgency relative to the forces of the regime. The stronger an insurgency gets, the more resilient it becomes, everything else being equal.

I first discuss in more detail why centralized groups are less resilient in the face of state military activity than decentralized groups. I then outline how the resilience of a rebel group in a given period is conditional upon both its organizational form and its military capacity relative to the state. I also show how the relative capacity of a rebel group varies over time, depending upon the amount of military capacity that the

${ }^{290}$ See Daniel Byman, "Do Targeted Killings Work?," Foreign Affairs, Vol.85, no. 2 (2006), 95-105. 
insurgency loses in its confrontations with the state and its ability to mobilize fresh support from the population and alternative sources. To substantiate the points that are made in the second subsection, I test the intuitions that I develop against evidence from Vietnam and Malaya.

4.2.1 - Organizational Resilience and Subunit Mutual Reliance: Centralization and CoDependence, Decentralization and Autonomy

\section{Figure 4.2. Subunit Mutual Reliance and Organizational Decentralization and Centralization}

$\begin{array}{cc}\text { Decentralized } & \text { Centralized } \\ \text { Groups } & \text { Groups }\end{array}$



Every organization is composed of various subunits of differing size, purpose, and disposition. How a group's subunits interact with one another is the fundamental difference between more centralized and more decentralized organizations. Interaction between subunits ranges along a continuum of varying degrees of subunit mutual reliance. All rebel groups can be placed along this continuum. As illustrated in Figure 4.2, centralized organizations have more mutually reliant subunits, while decentralized organizations have less mutually reliant (more autonomous) subunits. 
As outlined graphically in Figure 4.2, decentralized groups, which exhibit low levels of mutual reliance between subunits, exist at one end of the organizational mutual reliance continuum. As a result of the low intra-subgroup mutual reliance, decentralized organizations typically have more autonomous subunits. More autonomous subunit interaction means that the different parts of a broader organization do not rely heavily on the other parts of the organization in order to undertake a given task. Centralized groups, in contrast, are at the other end of the continuum and exhibit high levels of mutual reliance between organizational subunits. More mutually reliant subunit interaction means that activities undertaken by one subunit are either a prerequisite for or in some other way dependent upon actions undertaken by another subunit. Essentially, a centralized group's subunits are typically more co-dependent upon other units within the organization in order to function properly and obtain their maximum level of efficiency. Co-dependence between subunits is prone to disruption by state military activity and makes centralized organizations less resilient to state military activity. In more decentralized organizations, in contrast, subunits are typically more autonomous and can usually operate at peak efficiency (which is usually less efficient than in more centralized groups) without relying on the other parts of the broader organizational structure. High subunit autonomy makes decentralized organizations more resilient to state military activity. ${ }^{291}$

\subsection{2 - Centralized Groups: Mutually Reliant and Lacking in Resilience}

\footnotetext{
${ }^{291}$ The idea that centralized groups are less resilient to military pressure than decentralized groups is now a well-worn one. See, for example, Ori Brafman and Rod A. Backstrom, The Starfish and the Spider: The Unstoppable Power of Leaderless Organizations (Toronto: Portfolio, 2007). For this idea applied to insurgent groups, see Abdulkader H. Sinno, Organizations at War: In Afghanistan and Beyond (Ithaca: Cornell University Press, 2008).
} 
The high level of both mutual reliance and co-dependence between organizational subgroups that is a typical hallmark of more centralized organizations explains why such groups often lack resilience to state military activity. Imagine, for example, a fairly centralized organization that has specialized subunits that need to be coordinated, monitored, and controlled and that are dependent upon a small leadership group for operational, strategic, and political direction. For these specialized subunits to operate effectively, all the other aspects of the organization also need to be operating correctly as well, particularly the leadership group. For example, a subunit of an insurgency that is dedicated to war-fighting in a particular area and that relies upon a logistical unit to bring it armaments, food, and other supplies, would be unable to function well if the logistical unit's ability to undertake its task was hampered by state military activity. Similarly, neither group could presumably function to their maximum efficiency if a unit dedicated to coordination and strategic planning did not direct the two together, and so forth. What this means in more general terms is that if the ability of a centralized organization's subunits to rely upon one another is disrupted or completely curtailed by state military activity, the organization is very prone to having all its activities disturbed. At an extreme level of centralization, the group might even fragment into smaller groups or collapse completely if any one part of the organization is destroyed, say through leadership decapitation. ${ }^{292}$ Put another way, if the ability of the subunits to be mutually reliant is disrupted by state military activity, then each unit cannot function to the best of its ability, if it can function at all.

\footnotetext{
${ }^{292}$ On the idea that effective leadership decapitation in counterinsurgency can contribute towards counterinsurgent victory, see Patrick B. Johnston, "Does Decapitation Work?: Assessing the Effectiveness of Leadership Targeting in Counterinsurgency Campaigns," International Security, Vol. 36, no. 4 (2012), 4779.
} 
Historical evidence substantiates the idea that centralized groups that are effectively targeted by state military activity do have trouble absorbing the damage and can suffer many negative consequences, including outright group collapse. The bulk of these examples involve the targeting of segments of an insurgency, often the leadership element. While disruptions of mutual reliance can result from more generalized state military pressure, the loss of a group's leadership is particularly disruptive. In Indonesia in the 1950s, for example, during a military confrontation between the communist party and the state, "the extraordinary passivity displayed by most PKI activists and organizations in the face of their persecution, amounting in some cases to voluntary surrender to the authorities, betrays a like dependence on a disintegrated center." ${ }^{293}$ Centralization made the subunits of the PKI quite mutually reliant on the center of the organization for guidance and contributed significantly to the defeat of the Indonesian communist party. Likewise, after the death of Dr. Fathi Shikaki, the leader of the fairly centralized Islamic Jihad, the organization slumped and undertook little activity for several years. ${ }^{294}$

The FLN-ALN in the city of Algiers also exemplifies the lack of resilience exhibited by centralized insurgent groups. The FLN-ALN organized differently in the capital of Algeria than it did in other urban areas and in the rural countryside. As Abdulkader H. Sinno puts it, "under the influence of Leninist organizational thinking, the [FLN-]ALN in Algiers adopted a strictly pyramidal centralized structure. This centralized structure allowed it to execute some impressive high profile operations, but ultimately it

\footnotetext{
${ }^{293}$ Rex Mortimer, "Traditional Modes and Communist Movements: Change and Protest in Indonesia," John Wilson Lewis, ed., Peasant Rebellion and Communist Revolution in Asia (Stanford: Stanford University Press, 1974), 122.

${ }^{294}$ Abdulkader H. Sinno, Organizations at War: In Afghanistan and Beyond (Ithaca: Cornell University Press, 2008), 77.
} 
led to its defeat in the notorious Battle of Algiers." ${ }^{295}$ Indeed, data on FLN-ALN activity within Algiers bears out Sinno's observations. Once the French army began to apply significant military pressure against the FLN-ALN in Algiers in January 1957, insurgent attacks in the metropolitan area declined precipitously as the organization was disrupted and destroyed. From January to December 1956, for example, the insurgency launched an average of 53.75 attacks per month within Metropolitan Algiers. After the application of extensive French military pressure against the FLN-ALN within the city, the average number of attacks per month fell to 32.5 from January to October 1957. Excluding the month of January 1957, which included the start of the so-called Battle of Algiers, the average number of insurgent attacks per month within the city fell to 23.67 per month from February to October of that year. ${ }^{296}$ A one-tailed t-test on the number of attacks in 1956 compared to the number of attacks from February to October 1957 results in a $p$ value of 0.01409 . In other words, the difference in attacks is statistically significant at the 98 percent-level. French military pressure easily disrupted and destroyed the centralized FLN-ALN organization within Algiers, leading to fewer insurgent attacks.

In sum, centralized groups are typically efficient in their activity but lacking in terms of innate organizational resilience. This lack of resilience makes such groups quite susceptible to being broken by state military activity, everything else being equal.

\subsection{3 - Decentralized Groups: Lacking in Mutual Reliance but Highly Resilient}

The low level of subgroup mutual reliance and high subunit autonomy that is a hallmark of more decentralized organizations explains why rebel groups of this structure are

\footnotetext{
295 Ibid., 76.

${ }^{296}$ Data for these calculations is taken from Philippe Tripier, Autopsie de La Guerre D'Algerie (Paris: Editions France-Empire, 1972), Annexe 9.
} 
generally more resilient in the face of state military activity. ${ }^{297}$ For instance, if an insurgent organization is fairly decentralized, with diffuse decision-makers, weak coordination mechanisms, limited organizational specialization, and weak monitoring and control mechanisms, then each unit does not rely upon other parts of the broader organization when it undertakes a productive, military, or political activity. If a counterinsurgent's military activity removes some part of such a decentralized organization, the bulk of the remaining subunits would still be able to operate in more or less the same fashion as before the attack. In essence, the organizational structure of a decentralized insurgency is based upon the principle of subunit autonomy and low intragroup mutual reliance, which makes the various parts of the organization less productive but which also makes the group as a whole more resilient. Decentralized insurgencies are more resilient because the subunits of the organization do not need one another to operate effectively.

Comparative historical evidence from multiple insurgencies suggests that decentralized groups are, in fact, quite resilient to state military activity due to their low level of intra-organizational mutual reliance and high degree of subunit autonomy. As a result of this resilience, decentralized insurgencies are able to maintain their organizational integrity and operational tempo fairly well in the face of counterinsurgent military pressure. In British Malaya, for example, the Malayan Communist Party (MCP) was fairly decentralized. The effect of this structure, as John Coates nicely puts it, was that: "The MCP's district organizations were analogous to the compartments of a battleship's hull; it was possible for the insurgents to lose a number of them without

\footnotetext{
${ }^{297}$ For the comparable idea that terrorist groups that are likely decentralized are more resilient to leadership decapitation, see Jenna Jordan, "When Heads Roll: Assessing the Effectiveness of Leadership Decapitation," Security Studies, Vol. 18, no. 4 (2009), 719-755.
} 
causing the collapse of the state organization. However, the very robustness of such an organization, built up on a series of semi-independent entities, became a positive drawback when it wanted to take the offensive." ${ }^{298}$ The Uruguayan Tupamaros were targeted several times by police raids, even losing their figurehead, Raul Sendic, and other Tupamaros commanders in August of $1970 .{ }^{299}$ While the Tupamaros were eventually defeated, it remained fairly resilient to state military activity. The cause of this resilience, as Richard Gillespie puts it, was that the, "Tupamaro forces were divided into self-sufficient columns, each possessing its own recruitment, intelligence, military and technical apparata $[s i c]$, as well as their own fronts of work among the people, students, trade unions, and army. ... The boast of Tupamaro 'indestructibility' rested upon the belief that, even if several columns were wiped out completely, the others would be unimpaired and therefore able to go on operating and multiplying." ${ }^{300}$ In Aceh, Indonesia, the GAM insurgency was a fairly decentralized organization. At least partially due the fact that the GAM insurgency's core leadership lived in Sweden, the group had a limited hierarchy and a confused decision-making process, despite some appearance of a more linear topto-bottom organizational design. As would be expected, the lack of group centralization led to suboptimal coordination between rebel units and high agency costs due to weak control and monitoring. ${ }^{301}$ However, it also made the group fairly resilient to state military activity. For example, in 2002, Abdullah Syafi'i, military commander of the Free

\footnotetext{
298 John Coates, Suppressing Insurgency: An Analysis of the Malayan Emergency, 1948-1954 (Boulder: Westview Press, 1992), 57. and Revolution (Brighton: Wheatsheaf Books, LTD, 1986), 165. For similar points, see Robert Moss, Urban Guerrillas: The New Face of Political Violence (London: Temple Smith, 1972), 222. James Kohl and John Litt, Urban Guerrilla Warfare in Latin America (Cambridge: The MIT Press, 1974), 188.

${ }^{301}$ Kirsten E. Schulze, "The Free Aceh Movement (GAM): Anatomy of a Separatist Organization," Policy Studies 2 (Washington: East-West Center, 2004), 12-13.
} 
Aceh Movement, was killed by state forces. ${ }^{302}$ Despite the loss of the military commander within Aceh, the insurgency's military activity and performance was not too adversely affected. ${ }^{303}$

A similar pattern in found in other insurgencies. In 1957 in Algeria, several members of the leadership of the FLN insurgency were captured. But, as LieutenantColonel David Galula notes, "Their capture ... had little effect on the direction of the rebellion, because the movement was too loosely organized to crumble under such a blow." ${ }^{304}$ Earlier in Algeria, the OS, which was a militant wing of the nationalist MTLD, was targeted by state forces after a series of terrorist incidents and had a lot of its core leadership destroyed. But, "Because it was a carefully compartmentalized secret organization, many sections survived intact.... By and large, however, leaders were captured and filled prisons. The organization was decapitated, but many local cell members escaped notice and simply waited for leaders to contact them, and for an occasion to reorganize." ${ }^{305}$ Indeed, many elements of the OS re-emerged to form the core of the FLN a decade or so later.

The ancillary prediction of the idea that organizational centralization and low resilience run in tandem and that organizational decentralization and high group resilience go together is that calculating rebel groups should assume a decentralized organizational structure when they are under intense military pressure or devolve their structure in areas where such intense pressure is more likely to occur. Historical

\footnotetext{
302 "We Came From Allah and to Him We Return," Free Aceh Times, (no date). Accessed online at: http://www.achehtimes.com/news2002/syafie/, accessed on December 24, 2012.

${ }^{303}$ Kirsten E. Schulze, "The Free Aceh Movement (GAM): Anatomy of a Separatist Organization," Policy Studies 2 (Washington: East-West Center, 2004), 13.

${ }^{304}$ David Galula, Pacification in Algeria, 1956-1958 (Santa Monica: RAND Corporation, 2006), 141.

${ }^{305}$ Alf Andrew Heggoy, Insurgency and Counterinsurgency in Algeria (Bloomington: Indianapolis University Press, 1972), 34.
} 
evidence substantiates this corollary prediction. The CCP in Northern and Central China, for example, responded to intense Japanese military pressure in the 1940s with organizational decentralization. As Tetsuya Kataoka puts it, "A pyramid form of organization was pushed down into the ground, as it were, to make a squat shape concealed beneath the surface [of the population]." ${ }^{306}$ Likewise, in most of the main urban centres of Algeria, where the French counterinsurgents were strongest, "These zones were granted extensive authority in local matters. Decentralization was the insurgents' [usual] answer to these special problems in security." ${ }^{1307}$ Hence, when pressured by counterinsurgent military forces, rebel groups respond by adopting or changing to more decentralized forms of organization, plausibly because this sort of organizational structure increases the group's resilience to state military activity.

In sum, the degree of mutual reliance among organizational subunits differs from more centralized groups, which have high levels of mutual reliance and subunit codependence, to more decentralized groups, which have limited mutual reliance and high levels of subunit autonomy. The higher level of mutual reliance that characterizes more centralized organizations is prone to disruption by state military activity, which generally makes centralized groups less resilient in the face of state action. In contrast, the lower level of subunit mutual reliance that characterizes more decentralized groups entails that most individual aspects of the broader organizations can be destroyed by state military activity without any appreciable effect on the other parts of the groups. What this means is that more centralized groups are less resilient to state military activity due to high

\footnotetext{
${ }^{306}$ Tetsuya Kataoka, Resistance and Revolution in China: The Communists and the Second United Front (Berkeley: University of California Press, 1974), 277-278.

${ }^{307}$ Alf Andrew Heggoy, Insurgency and Counterinsurgency in Algeria (Bloomington: Indianapolis University Press, 1972), 128.
} 
subunit co-dependence and, in comparative terms, more decentralized groups tend to be more resilient due to high subunit autonomy, everything else being equal.

\subsection{4 - Total Group Resilience as a Product of Both Organizational Form and Relative Capacity}

In this subsection, I outline the more general relationship that exists between a rebel group's organizational type, its capacity relative to the counterinsurgent forces of the regime, and its resilience in the face of state military activity using a logistic form contest success function. ${ }^{308}$ I also modify the typical model of a contest success function by adding in a rebel group attrition curve, which indicates how much military capacity an insurgency loses in a period of confrontation with the state. In particular, I argue that, everything else being equal, the most resilient rebel groups are relatively strong compared to the state and are decentralized organizationally. Groups of this sort should have a fairly low chance of being defeated by state military activity in a given period. In contrast, groups that are weaker and organizationally centralized should be less resilient in the face of state military activity and have a larger chance of being beaten by regime military pressure.

In what follows, I first discuss the general use of a contest success function. Then, I present my own variation of the basic model and articulate how this type of model helps to conceptualize how the resilience of an insurgency is conditioned by both a rebel group's war-fighting capacity relative to the state and its organizational structure. The

\footnotetext{
${ }^{308}$ On contest success functions, see Charles H. Anderton and John R. Carter, Principles of Conflict Economics (New York: Cambridge University Press, 2009), 246-249; Jack Hirshleifer, "Theorizing About Conflict," in Keith Hartley and Todd Sandler eds., Handbook of Defence Economics, Vol. 1 (New York: Elsevier, 1995), 165-189; Michelle R. Garfinkel and Stergios Skaperdas, "Economics of Conflict: An Overview," in Todd Sandler and Keith Hartley eds., Handbook of Defense Economics, Vol. 2 (New York: Elsevier, 2007), 649-709.
} 
model also includes an attrition curve, which shows the relationship between how much state military capacity is used and how much of a rebel group is destroyed during a particular offensive. I then test the process and predictions of the model against historical evidence from America's war in Vietnam and the British counterinsurgency in Malaya.

\subsection{5 - Contest Success Functions: An Overview}

Contest success functions are classically used to model the hostile interaction of two parties, each of which employs its respective military capacity to try to obtain some distribution of a good or resource. ${ }^{309}$ After the two sides meet in conflict, each side controls some proportion of the disputed resource. Alternatively, if the object in dispute is indivisible, the majority winner of the contest controls the entire disputed item. The classical use of contest success functions is not iterative and largely lacks a dynamic component. In its typical formulation, more intensive use of military capacity results in a larger share of the contested resource, although the relative effectiveness of each side's military technology and the decisiveness advantage that comes with being a superior force do matter too. ${ }^{310}$

\subsection{6 - A Modified Contest Success Function: State Offensives, Rebel Group Resilience, and Rebel Attrition}

In my variation of a contest success model, I frame the conflict as an offensive campaign by the state against the insurgency. The goal of the state's military offensive is to disrupt and destroy a rebel group through military pressure, while also attempting to destroy

\footnotetext{
${ }^{309}$ See Charles H. Anderton and John R. Carter, Principles of Conflict Economics (New York: Cambridge University Press, 2009), 246.

${ }^{310}$ Ibid., 246.
} 
some of the rebellion's military capacity. The state, in this conceptualization, is on the offensive and employs some amount of military capacity to secure some chance of defeating an insurgency during a particular campaign. At the same time, the state's use of military capacity against the rebel group invariably results in the attrition of some of the rebel group's military capacity. The rebel group, conversely, is on the defensive and uses its military capacity in an attempt to reduce to the greatest possible extent the chances that it will be defeated. The insurgency also leverages both its military capacity and its strategy in an effort to reduce its rate of attrition in a given period of interaction.

By including attrition in the model, I am able to assess how a rebel group's lost military capacity during an initial offensive affects the later stages of the conflict and I thus incorporate a dynamic element into the framework. The dynamic element is important as it helps to explain the gradual wearing down and destruction of rebel groups. Whether the military capacity that an insurgency fields in a second period is either greater or less than the amount fielded in the initial period depends upon both the amount of the insurgency that is destroyed during the first offensive and the rate at which the insurgency can take in new capacity from internal and external sources. ${ }^{311}$ Thus, the amount of military capacity it can field across multiple state offensives can vary considerably. In the logistic form, the state's contest success functions, $\mathrm{P}_{\mathrm{S}}$, can be expressed as the following equation: ${ }^{312}$

$$
P_{s}=\frac{1}{1+\exp \left[d\left(\mathrm{ZM}_{\mathrm{R}}-\mathrm{M}_{\mathrm{S}}\right)\right]}
$$

\footnotetext{
${ }^{311}$ Nathan Leites and Charles Wolf, Jr., Rebellion and Authority: An Analytic Essay on Insurgency Conflict (Santa Monica: RAND Corporation, 1970), 32-33.

${ }^{312}$ These equations are derivatives of those found in Charles H. Anderton and John R. Carter, Principles of Conflict Economics (New York: Cambridge University Press, 2009), 248.
} 
In a given period of conflict, the state deploys $\mathrm{M}_{\mathrm{S}}$ amount of military capacity, while the rebellion deploys some amount $\mathrm{M}_{\mathrm{R}}$. Two additional factors weigh into the calculation to determine the probability that the insurgency is defeated by the state during a particular offensive. First, there is a decisiveness coefficient, $d$, which determines the rate at which an increase in military capacity for the predominant side transforms into more success in the conflict, either greater offensive success from the state's perspective or greater defensive success from an insurgency's perspective. Lastly, there is an additional parameter $Z$. The $Z$ parameter captures the effect of a rebel group's organizational structure on the relative effectiveness of the insurgency's military capacity. Since the insurgency is attempting to defend itself from the state's offensive military activity, the inherent resilience of a particular insurgency's organizational structure, that is, its innate ability to resist state military activity organizationally, conditions how effective a group's military capacity is at defending the organization as a whole.

The value of the parameter $Z$, which conditions the relative effectiveness of the insurgency at defending itself against the state's offensives, changes in accordance with the degree of organizational centralization that the rebel group adopts. In my formulation, the $\mathrm{Z}$ parameter ranges from a value of 1 to some amount $1+X$, where $X$ is some positive number. A Z parameter value of 1 means that the insurgent group relies on only its military capacity to defend itself from a state's offensive, because the group's organizational structure provides no additional benefits in terms of resilience against defeat. A highly centralized rebel group would have a $\mathrm{Z}$ parameter around 1 . In contrast, the inherent resilience of a decentralized organizational structure means that the $\mathrm{Z}$ parameter for a decentralized rebel group is some value $X$ greater than 1, which 
essentially means that the insurgency is able to leverage the inherent resilience of its organizational structure to resist the state's offensive military advances more effectively for any level of military capacity.

When the state and the insurgency lock in conflict during a particular period, the insurgency loses some amount of military capacity through death, capture, and defection. The amount of military capacity that the insurgency loses during a confrontation with the state affects whether or not it is able to field less, more, or the same amount of military capacity during a subsequent state offensive. A rebel group's lost capacity needs to be subtracted from the amount of new capacity that it obtains from mobilizing popular support and from alternative sources, such as external support, the sale of illicit crops, and lootable natural resources. ${ }^{313}$ If the net amount of new capacity is positive, the insurgency is able to field more military capacity in a later period, which decreases the chances that the state is able to defeat the insurgency. Clearly, the state also loses some capacity in its confrontations with an insurgency. In the following discussion, I assume that the state is able to employ some amount of military capacity in a given period and that the amount it can field is not related to how much it loses due to a rebel group's military activity. In actuality, the state's attrition rate matters, of course, but generally speaking counterinsurgents are able to field far more capacity than they use at any given point and time, so a counterinsurgency could suffer losses while continuing to field as much if not more capacity over time.

\footnotetext{
${ }^{313}$ Nathan Leites and Charles Wolf, Jr., Rebellion and Authority: An Analytic Essay on Insurgency Conflict (Santa Monica: RAND Corporation, 1970), 32-33.
} 
The equation for the insurgency's attrition curve can be expressed as the following: ${ }^{314}$

$$
A_{R}=\frac{-\left(S M_{R}\right)^{m}}{\left(M_{S}\right)^{m}+\left[\left(S M_{R}\right)^{m}\right]}
$$

In this equation, $\mathrm{M}_{\mathrm{S}}$ is the state's commitment of military capacity during a particular offensive. The amount of state capacity used to determine the state's contest success function is necessarily the same as the amount used to determine the insurgency's attrition curve in the same period. $M_{R}$ is the insurgency's committed military capacity, which, again, is the same as the amount of military capacity used to calculate the state's contest success function for the same period. The $m$ coefficient captures how effectively the commitment of military force translates into either the attrition of rebel capacity from the state's perspective or resisting attrition from the insurgency's perspective. The parameter $S$ is the rebel group's strategy variable and captures the type of strategy that the insurgency uses, ranging from a conventional (at a value of 1) upwards toward elusive guerrilla strategies that allow the insurgency to better control its rate of attrition. ${ }^{315}$

\footnotetext{
${ }^{314}$ This equation is a derivative of the ratio form contest success function found in Charles H. Anderton and John R. Carter, Principles of Conflict Economics (New York: Cambridge University Press, 2009),247. ${ }^{315}$ For example, Laia Balcells and Stathis Kalyvas find that conventional conflicts are the most deadly in terms of battlefield casualties, when compared to irregular and symmetric non-conventional conflicts. See, Laia Balcells and Stathis Kalyvas, "Does Warfare Matter? Severity, Duration, and Outcomes of Civil War," ICIP Working Papers no. 5 (November 2012), 7-37.
} 
Figure 4.3. The State's Offensive Contest Success Function and a Rebel Group's Relative Capacity and Organization



Figure 4.3 outlines heuristically how these two processes interact to show both how resilient an insurgency is in the face of state military pressure during a particular period and how likely the insurgency is to grow or decline during the course of multiple state offensives. In Figure 4.3, the $x$-axis denotes the amount of military capacity (with 
undefined whole units) that the state brings to bear upon the insurgency during an offensive period. The positive $y$-axis, which is the measure of the outcome of the conflict period, is a proportional measure ranging from 0 to 1 and denotes the amount of rebel group activity that is disrupted by the state offensive. The logistic contest success function (CSF) depicts the relationship between an increase in the state's employment of military capacity, $\mathrm{M}_{\mathrm{S}}$, and the proportion of rebel group organizational activity that it disrupts, given some decisiveness coefficient, $d$, the military capacity of the rebel group, $\mathrm{M}_{\mathrm{R}}$, and the inherent resilience of the insurgency's organizational structure, $\mathrm{Z}$. The state's conflict success function begins part of the way up the $y$-axis because its incumbency status means that it disrupts a nascent insurgency's activity without even undertaking a military offensive due to the deterrent effect of its arsenal of military capacity.

The negative $y$-axis (which retains positive values for simplicity's sake) denotes the proportion of a rebel group that is destroyed during a particular offensive by the state. Rebel losses occur through three related processes: 1) death and maiming due to military confrontations with the state, 2) the state's capture of rebels, and 3) individual defection from rebel ranks. In general, the more military capacity the state employs during a particular offensive, the higher the losses due to death, maiming, capture and the higher the defection from rebel ranks. The rebel group's attrition curve (AC) denotes the rate at which an increase in the state's military capacity results in a loss of rebel group military capacity through casualties, capture, and defection. As I point out in more detail below, the amount of military capacity that an insurgency can field in a second period of confrontation is conditional upon both the amount of capacity it loses during some initial 
state offensive and the rate at which it can intake new inputs from internal and external sources. ${ }^{316}$

A heuristic example should help to clarify the logical operation of the model. I follow this heuristic example with some empirical evidence from state offensives against the insurgencies in Vietnam and Malaya. Imagine, first of all, that the state fields some 400 units of military capacity during an initial offensive campaign. Assume also that given this deployment of regime forces, the amount of rebel group military capacity, and the organizational structure of the insurgency, the state ends up along its contest success function CSF (1). The 400 units of state military capacity allow the state to disrupt 50 percent of the insurgency's organizational activity. At the same time, the state's use of military capacity in an offensive against the insurgency causes some attrition of the rebel group's capacity. Imagine that the rebellion is along its attrition curve AC (1), which is conditioned by the amount of capacity the state fields, the amount of military capacity the insurgency fields, and the strategy that the rebel group adopts. In this case, the 400 units of state military capacity result in a loss of around 40 percent of the insurgent group's military capacity through casualties, capture, and defection.

The percentage measure of how much of a rebel group is destroyed translates into some absolute amount, given the total size of the insurgency. For example, assume that the insurgency loses 100 units of military capacity due to the state's offensive and that this is 40 percent of the group's total capacity. At the same time, let's say that the insurgency is able to mobilize some 350 units of new capacity by purchasing popular support through the provision of remunerative compensation and the use of preference

\footnotetext{
${ }^{316}$ Nathan Leites and Charles Wolf, Jr., Rebellion and Authority: An Analytic Essay on Insurgency Conflict (Santa Monica: RAND Corporation, 1970), 32-33.
} 
manipulation tactics. In net terms, after the losses are subtracted from the newly obtained resources, the insurgency's capacity has grown by a maximum of 250 units. If we assume that some of the newly obtained capacity, say 150 units, is devoted towards the production of more popular support-securing outputs in a future period, then the insurgency is, in a second conflict period $\mathrm{T}+1,100$ units of military capacity stronger than it was during the state's initial offensive in period $\mathrm{T}$.

If the insurgency did indeed become 100 units stronger after the first offensive and if the state launched a second offensive using another 400 units of state military capacity, the state's contest success function would be, say, CSF (2), assuming that the insurgency's organizational structure is constant. With this new contest success function, the state disrupts around 20 percent of the insurgency's activity during the offensive, which is far less than the initial 50 percent that the 400 units of state military capacity secured during the original offensive. Similarly, if we assume that the additional military capacity shifts the rebel group's attrition curve to AC (2), then, as a result of the state's second offensive involving 400 units of state military capacity, the insurgency loses only around 10 percent of its total military capacity to death, maiming, and defection. The proportional amount of attrition that the insurgency suffers is reduced, when compared to the initial period, because the insurgency is more militarily capable and so better able to fight off the advances of the state. At the same time, since the size the insurgency is larger in absolute terms, the real number of insurgents killed might increase, even though the damage done by the state's offensive declines in proportional terms.

Of course, the opposite movement might occur if the state was able to destroy more military capacity than the insurgency could mobilize in replacement. If an 
insurgency shrunk in size following an initial offensive, then a second offensive would end up being more favourable from the state's perspective. For instance, an initial offensive could occur along the state's contest success function CSF (2). And, if the state fielded, say, 600 units of military capacity, it would disrupt around 60 percent of the insurgency's activity. Moreover, assuming that the insurgency is on its attrition curve AC (2), the state's commitment of 600 units of military capacity during the offensive would destroy around 25 percent of the rebel group's military capability. Assume that this proportion translates over into 50 units of military capacity. If the rebellion was only able to take in 25 units of new capacity through the mobilization of popular support and alternative sources, then the amount of military capacity that the insurgency could field in the second period would shrink by at least 25 units. If the decline in an insurgent group's military capacity shifted the state's contest success function to CSF (1) and the rebel's attrition curve to $\mathrm{AC}$ (1), then, in a second offensive, the state could field, say, 400 units of military capacity and disrupt around 50 percent of the insurgency's activity. It would also destroy 40 percent of the rebellion's military capacity in the second period, which would be 70 units of military capacity. If the rebellion was still only able to mobilize 25 units of additional capacity, then the insurgency would shrink by another 45 units heading into any subsequent period of conflict with the state, further favouring the regime in its efforts to fully disrupt rebellion.

\subsection{7 - Vietnam and Malaya: Empirical Examples of the Conflict Success Function and Attrition Curve}

Empirically, the processes linking group resilience to an insurgency's organizational structure and capacity relative to the regime, as outlined in the model, hold in Vietnam 
and Malaya. In Vietnam, the state was unable to destroy the insurgency's capacity at a greater rate than the insurgency mobilized new capacity through popular support and external assistance from North Vietnam. The result was an ever-growing insurgency that eventually defeated the United States and the South Vietnamese government. In Malaya, the British counterinsurgency was able to destroy the insurgency's military capacity at a faster rate than the rebel group could take in new support. What this meant was that, over time, the size and activity level of the Malaya communist insurgency declined, until it was eventually defeated by the state.

In Vietnam, for example, state forces were largely unable to inflict enough damage to the insurgency to cause it to decline in size over time, which meant that eventually the insurgency defeated the state. ${ }^{317}$ Robert McNamara summed up the basic trouble for United States and South Vietnamese forces in a memorandum dated October 14, 1966:

The one thing demonstrably going for us in Vietnam over the past year has been the large number of enemy kill-in-action resulting from big military operations. Allowing for possible exaggeration in reports, the enemy must be taking losses--deaths in and after battle--at the rate of more than 60,000 a year. ... Yet there is no sign of an impending break in enemy morale and it appears that he can more than replace his losses by infiltration from North Vietnam and recruitment in South Vietnam. ${ }^{318}$

Additional estimates produced in 1966 suggest that the average weekly loss of Vietcong and North Vietnamese insurgent forces was 2,330 personnel. This rate of attrition was obtained with 400,000 American personnel in the South Vietnam theatre. American

\footnotetext{
${ }^{317}$ See, for example, Richard Shultz, "Breaking the Will of the Enemy During the Vietnam War: The Operationalization of the Cost-Benefit Model of Counterinsurgency Warfare," Journal of Peace Research, Vol. 15, no. 1 (1978), 109-129; Richard Shultz, "Coercive Force and Military Strategy: Deterrence Logic and the Cost-Benefit Model of Counterinsurgency Warfare," Political Research Quarterly, Vol. 32, no. 4 (1979), 444-466.

${ }^{318}$ Robert McNamara, "Actions Recommended For Vietnam," in George C. Herring, ed., The Pentagon Papers: Abridged Edition (New York: McGraw-Hill, 1993), 159-160. Emphasis added.
} 
forces also estimated, as Richard Shultz puts it, that "it could increase enemy weekly casualties at a rate of 230 for each 100,000 troops deployed above the 400,000 level." ${ }^{\prime 319}$ The poor force-to-attrition ratio was partially produced by the guerrilla strategy that the Vietcong insurgency employed, which, up to 1968, allowed them to control an estimated 85 percent of the changes in their casualty rates by avoiding unfavourable combat situations. ${ }^{320}$ Moreover, in absolute terms, it was estimated that the Vietcong insurgency could mobilize a rough average of 3,500 recruits per week, with at least 2,275 coming from South Vietnam and an additional 1,225 recruits pouring in from the North. ${ }^{321}$ Period over period, these loss-to-gain figures indicate that the insurgency in South Vietnam was growing at a possible net average rate of 1,170 new recruits per week. The fact that the insurgency could maintain this level of mobilization activity, despite the intense pressure that the United States and the DRVN brought against it, is a testament to both the efficiency of the group's mobilization and how little of the insurgency's activity was disrupted as a result of state military pressure. The efficiency of the Vietcong's domestic mobilization was clearly enhanced by its centralized organizational structure, which, as the numbers indicate, allowed it to mobilize thousands of individuals per week. ${ }^{322}$ The resilience of the insurgency's organizational processes in the face of counterinsurgent military pressure was mostly a result of the strength of the Vietcong, as the organization itself was fairly centralized and so quite prone to disruption.

\footnotetext{
${ }^{319}$ Richard Shultz, "Coercive Force and Military Strategy: Deterrence Logic and the Cost-Benefit Model of Counterinsurgency Warfare," Political Research Quarterly, Vol. 32, no. 4 (1979), 460.

${ }^{320}$ These estimates are found in Thomas C. Thayer, "We Could Not Win the War of Attrition We Tried to Fight," in W. Scott Thompson and Donaldson D. Frizzell eds., The Lessons of Vietnam (New York: Crane, Russak, and Co., 1977), 88-89.

${ }^{321}$ Richard Shultz, "Coercive Force and Military Strategy: Deterrence Logic and the Cost-Benefit Model of Counterinsurgency Warfare," Political Research Quarterly, Vol. 32, no. 4 (1979), 460.

${ }^{322}$ Douglas Pike, Vietcong: The Organization and Techniques of the National Liberation Front (Cambridge: The MIT University Press, 1968).
} 
As the model suggests, over time, the chances that the counterinsurgency in Vietnam was going to be able to defeat the insurgency diminished. Likewise, the total amount of insurgents (or at least individuals counted as insurgents) that were killed or otherwise removed from combat rose in subsequent conflict periods, even as the proportion of the insurgency that was destroyed likely fell. ${ }^{323}$ Overall, the Vietnam example shows that the insurgency's attrition rate was conditioned by the number of United States personnel used during combat and both the size and strategy of the insurgency. ${ }^{324}$ In this case, the counterinsurgency was not able to destroy some proportion of the rebel group faster than the insurgency was able to mobilize new capacity. As a result, there was a gradual spiral of a growing insurgency and a declining probability that the state could defeat the rebellion. In the end, the Vietcong insurgency, despite being a fairly centralized organization with clear hierarchy in its decision-making, specialization, coordination mechanisms, and control and monitoring systems, proved to be very resilient because it became very strong. ${ }^{325}$

While using military force to slowly destroy the insurgency in Vietnam failed, in Malaya the state was able to exert enough military pressure to surpass the ability of the insurgency to recoup its losses, which meant that the insurgency fielded less and less military capacity over time as the regime quickly edged toward victory. Table 4.1 shows that the British counterinsurgents who fought the Malayan Communist insurgency were

\footnotetext{
${ }^{323}$ On the rise in total numbers, see Ibid., 460.

${ }^{324}$ Clearly, other factors, like the safe haven that the insurgency received in the North and in Laos and Cambodia, also affected the attrition rate of the Vietcong. In my formulation here, I would posit that the effect that external sanctuary had on the rebel group's attrition rate was conditional upon the strategy that the Vietcong employed, so the effect gets included via the strategy variable $S$ in the attrition function. Had they decided to stand and fight, rather than employ a guerrilla strategy, their available sanctuary would have availed them little.

${ }^{325}$ Douglas Pike, Vietcong: The Organization and Techniques of the National Liberation Front (Cambridge: The MIT University Press, 1968), 210-231.
} 
able to destroy more insurgents than the Min Yuen (which was the Communist's civilian infrastructure for mobilizing popular support) was able to replace. As early as 1951, regime forces were able to seriously reduce the net amount of growth in new insurgents that the rebellion was able to obtain. By 1952, the British counterinsurgents were destroying more insurgents than the rebellion was able to mobilize, meaning that the insurgency was shrinking year over year. This trend continued until 1956, when the insurgency was fairly well beaten, although the Malayan Emergency officially continued until $1960 .{ }^{326}$ Key to this process was the judicious application of military pressure. As Richard Clutterbuck notes, "Without military pressure, then, there were no surrenders. But once the first few SEPs [surrendered enemy personnel] came in, their information and cooperation led to more pressure by the army, which led to more narrow escapes, more kills, and more surrenders--a kind of galloping consumption that was fatal" to the Malaya insurgency. ${ }^{327}$

The insurgency's ability to withstand counterinsurgent military pressure without collapsing sooner than it did is at least partially attributable to its decentralized organizational structure, which ensured that some elements of the insurgency could be destroyed without resulting in the total destruction of the entire rebel group. ${ }^{328}$ At the same time, the organizational decentralization of the Malayan communist insurgency inhibited its ability to mobilize popular support, which eventually led to the group's defeat. Additionally, the insurgency had no external support and so it could not augment

\footnotetext{
${ }^{326}$ Eric Jardine, "The Influence of Military Materiel on Tactics and Strategy in Counterinsurgency: A Case of British Malaya," Defence Studies, Vol. 11, no. 4 (2011), 636-657.

${ }^{327}$ Richard Clutterbuck, The Long, Long War: The Emergency in Malaya, 1948-1960 (Toronto: Cassell \& Company, Ltd., 1967), 107.

${ }^{328}$ John Coates, Suppressing Insurgency: An Analysis of the Malayan Emergency, 1948-1954 (Boulder: Westview Press, 1992), 57.
} 
its capacity in this way. ${ }^{329}$ Other counterinsurgent programs, such as popular resettlement, also effectively disrupted the link between the insurgency and the population, making it harder and more costly for the communists to mobilize popular support. ${ }^{330}$ This trend is indicated in column five in Table 4.1 by the declining ability of the insurgency to mobilize popular support from 1950 onwards.

\begin{tabular}{|l|l|l|l|l|l|}
\hline \multicolumn{6}{|l|}{ Table 4.1. Insurgent Size, Attrition, and Replacement in Malaya } \\
\hline $\begin{array}{l}\text { Year } \\
\text { (January) }\end{array}$ & $\begin{array}{l}\text { Number of } \\
\text { Insurgents }\end{array}$ & $\begin{array}{l}\text { Number of } \\
\text { Insurgents } \\
\text { Killed, } \\
\text { Captured, or } \\
\text { Surrendered }\end{array}$ & $\begin{array}{l}\text { Proportion } \\
\text { of Rebel } \\
\text { Group } \\
\text { Destroyed }\end{array}$ & $\begin{array}{l}\text { Rebel Group } \\
\text { Capacity } \\
\text { Mobilization } \\
\text { in Prior } \\
\text { Period }\end{array}$ & $\begin{array}{l}\text { Change } \\
\text { in Rebel } \\
\text { Group } \\
\text { Size }\end{array}$ \\
\hline 1949 & 5,000 & 1,207 & $24 \%$ & N/A & N/A \\
\hline 1950 & 7,500 & 942 & $13 \%$ & 3,707 & 2,500 \\
\hline 1951 & 8,200 & 2,047 & $25 \%$ & 1,642 & 700 \\
\hline 1952 & 7,800 & 2,123 & $27 \%$ & 1,647 & -400 \\
\hline 1953 & 6,200 & 1,683 & $27 \%$ & 523 & $-1,600$ \\
\hline 1954 & 4,900 & 1,174 & $24 \%$ & 383 & $-1,300$ \\
\hline 1955 & 3,345 & 863 & $26 \%$ & -381 & $-1,555$ \\
\hline 1956 & 2,566 & $493 *$ & 84 & -779 \\
\hline $\begin{array}{l}* \\
\text { Densurgents that this value is taken from a different source than the remaining estimates of destroyed }\end{array}$ \\
\hline
\end{tabular}

In the Malayan case, the state was able to apply enough pressure to destroy more capacity than the insurgency could mobilize. While the organizational decentralization of the Malayan communist insurgency kept the group from collapsing sooner than it eventually did, the continual loss of military capacity that afflicted the insurgency meant

\footnotetext{
${ }^{329}$ Ibid., 49.

${ }^{330}$ Wade Markel, "Draining the Swamp: The British Strategy of Population Control," Parameters, Vol. 36, no. 1 (Spring 2006), 35-48; Eric Jardine, "Why Time Works against a Counterinsurgency," Journal of Military and Strategic Studies, Vol. 11, no. 4 (2009), 1-34.

331 John Coates, Suppressing Insurgency: An Analysis of the Malayan Emergency, 1948-1954 (Boulder: Westview Press, 1992). Data on the estimated size of the insurgency is found on page 76, footnote 76. 332 Data on the number of insurgents destroyed per period are drawn from John Coates, Suppressing Insurgency: An Analysis of the Malayan Emergency, 1948-1954 (Boulder: Westview Press, 1992), Appendix A.1 through A.6, Emergency Statistics in Detail. The * means the data for 1956 was taken from an alternative sources. See Ibid., Appendix B.
} 
that the amount of military resources that it could field decreased over time. By 1956, the insurgency was all but officially beaten.

The conflict success and attrition model presents an intuitive way to understand how an insurgency's resilience in the face of state military pressure is conditioned by both its military capacity relative to the state and its organizational structure. It also shows that these variables are far from static and that even the most organizationally resilient insurgency can be eroded until it shrinks into non-existence if it is losing more capacity to state military activity than it is able to mobilize via popular support or alternative sources.

In sum, I have argued that a rebel group's degree of organizational centralization affects its resilience to state military pressure, with more centralized groups generally being less resilient than more decentralized groups. More centralized groups are less resilient because their subunits are mutually reliant, which means that each organizational subunit is dependent upon other parts of the organization in order to function properly. A centralized organization's high degree of mutual reliance generally makes the group more efficient, but it is also prone to disruption, which can cause organizational disarray and even outright collapse. I also argued that an insurgency's resilience in the face of state military activity is also conditioned by a rebel group's level of military capacity relative to the state. Relatively stronger rebel groups are able to resist more state military activity than a relatively weaker group.

Once again, insurgents face a dilemma. Rebel groups that are organizationally decentralized are more resilient, so the chances that they will be destroyed by the state are smaller than if their organizational structure was more centralized. However, 
organizationally decentralized insurgent groups are also inefficient at producing popular support-securing outputs, which means they should obtain less support than more centralized groups, as the differential mobilization rates of the Vietcong and the MCP illustrate. As outlined above, an insurgency's ability to replace its lost military capacity is core to its long-term survival. Thus, an insurgency has to trade off, at some stage or another, its ability to withstand military pressure without being defeated against its ability to mobilize enough popular support to grow its capacity over time.

\section{3 - Conclusions}

In this chapter, I have argued that there are clear disadvantages to being a rebel group with a large-scale administrative presence and a high degree of organizational centralization. Insurgent groups increase the scale of their administrative presence in order to secure economies of scale in the production of popular support-securing outputs, which allow the group to grow faster and larger over time. However, as the scale of a group's administrative presence increases, an insurgency loses some of its tactical mobility and gains a heightened contrast between its organization and the surrounding population. Both of these emergent characteristics make it easier for the state to identify and target the insurgency. In the end, insurgencies with a small scale administrative presence should be comparatively hard for the state to target when compared to a similar insurgency with a large scale presence.

Organizational centralization is efficiency producing because it means that a group's subunits are mutually reliant. However, this mutual reliance is prone to disruption. If the state is able to target a highly centralized insurgency with military force, the mutual reliance between the organization's subunits can be severely impaired if not 
disrupted outright. The group's ability to undertake tasks suffers as a result. Indeed, at high enough levels of centralization, and given a strong enough push, the group might totally collapse. Decentralized groups, in contrast, exhibit low levels of subunit mutual reliance. This low level of mutual reliance makes decentralized organizational typically less efficient, but it also increases the innate amount of resilience the group is likely to exhibit. As a result, decentralized groups are harder to destroy with military means, everything else being equal.

In the next chapter, I weave these threads together to formulate a theoretical baseline statement on why some rebel groups win and others lose. 


\section{Chapter 5: Why do some rebel groups win and others lose?}

The mobilization and conflict outcome theory suggests that there is a relationship between a rebel group's need to mobilize popular support, how the group structures itself both organizationally and administratively in order to obtain high levels of popular support, and the state's ability to defeat an insurgency. The presence of this relationship raises three final questions that I address in this chapter:

1. What is the general relationship between an insurgent group's mobilization of popular support and conflict outcome?

2. If the theory is correct, what should we expect to see across multiple insurgencies?

3. What factors, as suggested by the theory, affect conflict outcome?

In this chapter, I derive an answer to the overarching research question of this work, namely, why do some rebel groups win while others lose? In its simplest formulation, the mobilization and conflict outcome theory predicts that the relationship between a rebel group's actual mobilization of popular support and the odds that the state can effectively defeat the insurgency is shaped like an inverted-U. At first, the state becomes more likely to win as the insurgency mobilizes more popular support, until the rebellion is stronger than the state. At the same time, a rebel group's mobilization of popular support increases its own chances of winning. Combined, these two trends suggest that as an insurgency mobilizes higher levels of popular support, the state becomes more likely to defeat an insurgency and the insurgency actually becomes more likely to defeat the state. As both parties become more likely to defeat their respective 
opponents, the odds that both sides will simply persist to fight another day decline, making the conflict more intense and more likely to produce a resolution.

In the first section, I outline the relationship between an insurgent group's mobilization of popular support through an exchange process and the likelihood that the state can defeat the insurgency. I start by briefly defining how I conceptualize rebel group success and failure. Following Jeff Goodwin, I argue that, in any given period of time, an insurgency can succeed, fail, or simply persist. ${ }^{333}$ The overall discussion in this first subsection is meant to form a theoretical baseline of how likely the state is to defeat an insurgency and how likely the insurgency is to beat the state. A theoretical baseline of this sort is important because assessing the causal effect that other variables have on the probability of a rebel group's success or failure requires some understanding of what the general odds are that the either the state or the insurgency would win before any additional variables are added. In this sense, the theoretical baseline allows for a more thorough causal assessment of the variables that alternatively favour the efforts of either the state or the insurgency. ${ }^{334}$

In the second section, I determine, in a preliminary way, the validity of the baseline framework. To do so, I derive and test three hypotheses from the mobilization and conflict outcome theory. These predictions are effectively logical implications of the core theory. Since the data to directly test the theory does not exist (reliable measures of popular support, both active and passive, do not exist), I test the some of the main implications of the theory to triangulate the general validity of the core theoretical notion.

\footnotetext{
333 Jeff Goodwin, No Other Way Out: States and Revolutionary Movements, 1945-1991 (New York: Cambridge University Press, 2003), 217-229.

${ }^{334}$ For a definition of causation involving the use of counterfactuals and the difference between the realized and the baseline outcome, see Gary King, Robert O. Keohane, and Sidney Verba, Designing Social Inquiry: Scientific Inference in Qualitative Research (Princeton: Princeton University Press, 1994), 76-82.
} 
In the third section, I outline how various factors can affect a rebel group's mobilization of popular support by determining the relative favourability of what I call the group's mobilization context. In turn, I specify how these conditions contribute to a rebel group's success or failure by making it easier or harder for the group to mobilize popular support, with all the attendant organizational and administrative consequences. I then specify those conditions and trace out how they affect a state's chances of beating an insurgency, which, by extension, affects conflict outcome.

\section{1 - What is the General Relationship between an Insurgent Group's Mobilization of Popular Support and Conflict Outcome?}

In this section, I argue that the relationship between growing popular support for an insurgency and rebel group success is positive, but that the relationship between a rebel group's mobilization of popular support and state success is shaped like an inverted-U. The shape of these relationships essentially means that two fundamentally antagonistic processes occur simultaneously as an insurgent group mobilizes higher levels of popular support through the exchange relationship that is at the core of the mobilization and conflict outcome theory. On the one hand, the insurgency's odds of winning go up as it mobilizes more popular support. On the other hand, as an insurgency mobilizes higher levels of popular support, insofar as it requires organizational centralization and an expansion of the group's administrative presence, the state's chances of defeating the insurgency increase. A rebel group's mobilization of popular support, therefore, is both necessary and dangerous for the overall viability of an insurgency.

In presenting a baseline conceptualization of how popular support for a rebel group affects conflict outcome, I assume a general ceteris paribus context. Many other 
factors affect the exchange relationship that is at the core of an insurgent group's mobilization of popular support. To develop a clear theoretical baseline, I assume, for the moment, that all other factors are equal. As I later show, when this assumptions is relaxed, changes to the value of other variables clearly affect the outcome of the conflict. For now, I maintain the broad simplifying assumption to generate a clear baseline understanding of the trend in insurgent success and failure as it is suggested by the mobilization and conflict outcome theory.

The mobilization and conflict outcome theory is probabilistic in its assessment of how a conflict should end, but it also disaggregates the process of a conflict into cycles or periods. Every conflict, broadly defined, has a single outcome. Eventually, either the state or the insurgency wins more or less decisively. Getting to a particular outcome, however, requires that the parties to a conflict interact and attempt to defeat one another. Usually, this process of conflictual interaction occurs many times over, with the ebb and flow of the conflict in one period affecting later periods of interaction. Viewed in this fashion, all internal wars are really a series of conflict cycles between the state and the insurgency, perhaps covering seasons or years. ${ }^{335}$ Viewed as a series of discrete, but clearly interrelated, cycles of interaction, an insurgency can win, lose, or simply continue fighting without a significant prospect of either success or failure in any particular period. ${ }^{336}$ What this essentially means is that during any given year, say, a rebel group could win, lose, or it could simply last through to fight again the following year. In what

\footnotetext{
${ }^{335}$ For a detailed account of how the different seasons saw different levels of conflict in Vietnam during both the French and the American wars, see Thomas C. Thayer, "Patterns of the French and American Experience In Vietnam," in W. Scott Thompson and Donaldson D. Frizzell eds., The Lessons of Vietnam (New York: Crane, Russak, and Co., 1977), 17-38.

336 Jeff Goodwin, No Other Way Out: States and Revolutionary Movements, 1945-1991 (New York: Cambridge University Press, 2003), 217-229.
} 
follows, I discuss how a rebel group's mobilization of popular support simultaneously increases the odds that the state can defeat an insurgency, increases the odds that the insurgency can beat the state, and typically reduces the odds that the parties will simply persist and carry on into the next conflict cycle.

As discussed in the first chapter, popular support for an insurgency and the likely outcome of a conflict cycle seems to have a fairly straightforward relationship. ${ }^{337}$ The conventional perspective is that as an insurgent group's level of popular support increases, its chances of success go up and the state's chances of success go down. ${ }^{338}$ More popular support is, in this view, pretty well always a good thing for an insurgency. As Mao Tse-Tung puts it, "Because guerrilla warfare basically derives from the masses and is supported by them, it can neither exist nor flourish if it separates itself from their sympathies and cooperation. [...] The moment that this war of resistance dissociates itself from the masses of the people is the precise moment that it dissociates itself from the hope of ultimate victory." ${ }^{339}$ Likewise, Ernesto "Che" Guevara posits that, "Guerrilla warfare is a war of the masses, a war of the people. ... The guerrilla fighter needs full help from the people of the area. This is an indispensable condition" [for a successful conflict outcome]. ${ }^{340}$ Mirroring these sentiments, Lieutenant Colonel David Galula posits that, "If

\footnotetext{
${ }^{337}$ For a more nuanced view, see Gordon H. McCormick, Steven B. Horton, and Lauren A. Harrison, "Things Fall Apart: The Endgame Dynamics of Internal Wars," Third World Quarterly, Vol. 28, no. 2 (2007), 321-367.

${ }^{338}$ See, for example, Mao Tse-Tung, On Guerrilla Warfare (New York: Dover Publications, Inc., 2005), 44; The Handbook for Volunteers in the Irish Republican Army, cited in, Eli Berman, Jacob N. Shapiro, and Joseph H. Felter, "Can Hearts and Minds Be Bought? The Economics of Counterinsurgency in Iraq," Journal of Political Economy, Vol. 119, no. 4, (August 2011), 767; David Galula, Counterinsurgency Warfare: Theory and Practice (Westport: Praeger Security International, 2006), 4; Bernard B. Fall, cited in, Bard O'Neill, Insurgency \& Terrorism: Inside Modern Revolutionary Warfare (Dulles: Brassey's, Inc., 1990), 70; Roger Trinquier, Modern Warfare: A French View of Counterinsurgency (Westport: Praeger Security International, 2006), 6.

${ }^{339}$ Mao Tse-Tung, On Guerrilla Warfare (New York: Dover Publications, Inc., 2005), 44.

${ }^{340}$ Che Guevara, Guerrilla Warfare (Lincoln: University of Nebraska, 1998), 9-10.
} 
the insurgent manages to disassociate the population from the counterinsurgent, to control it physically, to get its active support, he will win the war." ${ }^{341}$ Lieutenant Colonel Roger Trinquier, claims, in a similar fashion, "We know that the sine qua non of victory in modern warfare is the unconditional support of a population." ${ }^{342}$

\section{Figure 5.1. Rebel Group Relative Capacity and Chance of State Victory}

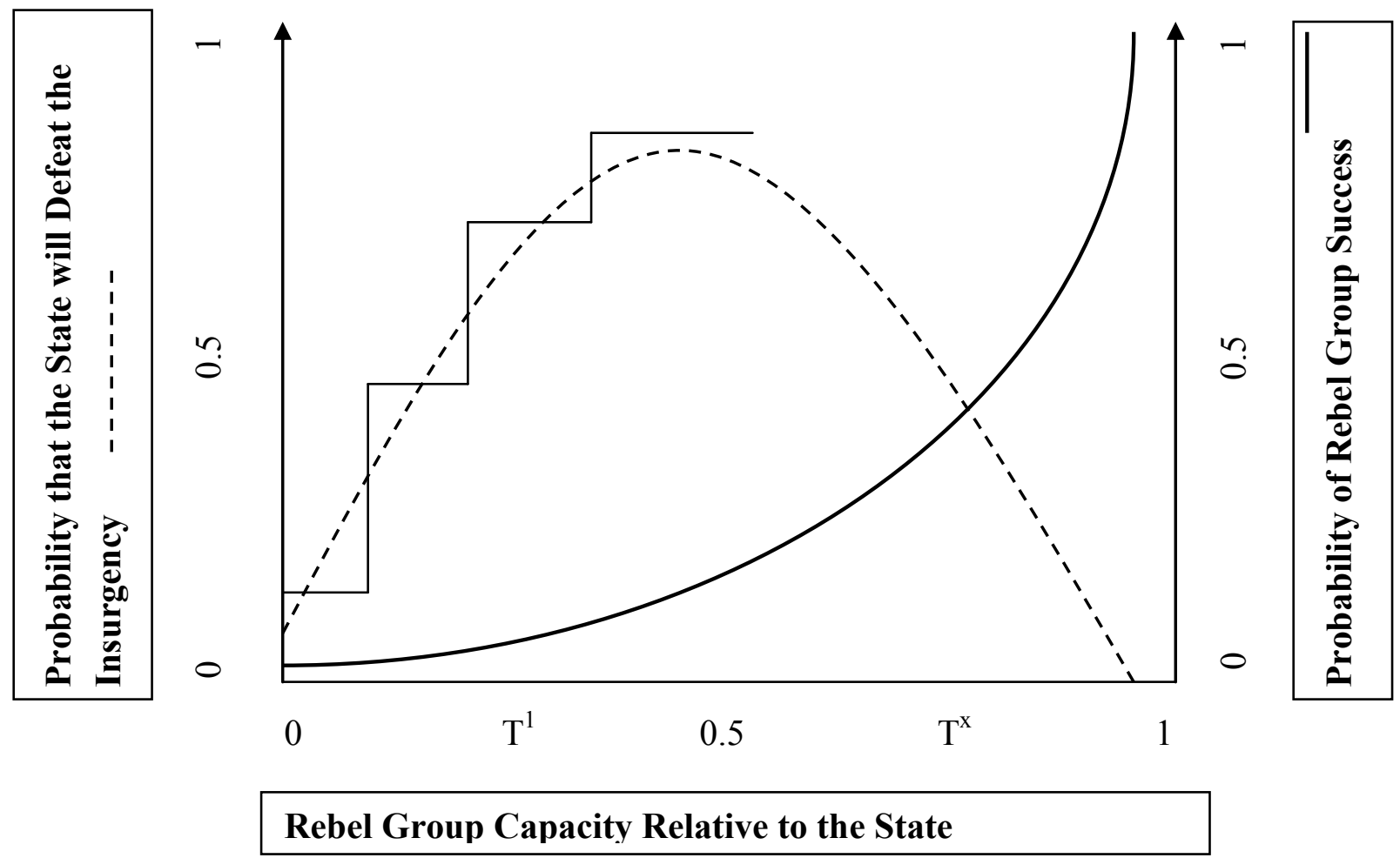

The mobilization and conflict outcome theory posits a differently structured relationship between a rebel group's actual mobilization of popular support and conflict outcome. This relationship is presented in Figure 5.1. The rebel group's capacity relative

\footnotetext{
${ }^{341}$ David Galula, Counterinsurgency Warfare: Theory and Practice (Westport: Praeger Security International, 2006), 4.

${ }^{342}$ Roger Trinquier, Modern Warfare: A French View of Counterinsurgency (Westport: Praeger Security International, 2006), 6. Emphasis in original.
} 
to the state is depicted along the $\mathrm{x}$-axis. The $\mathrm{x}$-axis is a measure of the relative share of the total mobilized capacity controlled by both the state and the insurgency within the conflict area. At origin on the x-axis, the state controls all the mobilized capacity within the country. At this point, the insurgency is, effectively, non-existent. At a value of one on the $\mathrm{x}$-axis, the insurgency controls all the mobilized capacity within a country and the state controls none, which basically means that the state has been thoroughly beaten and displaced by the rebellion. Since the rebel group's capacity relative to the state increases as it mobilizes popular support, an insurgent group that is only able to obtain a small amount of popular support in a given period is near to the origin point on the x-axis, while a group that is able to obtain a lot of popular support is nearer to the far right hand side of the x-axis. In a dynamic sense, as an insurgent group secures more popular support through the production of popular support-securing outputs, it moves from origin towards the far right hand side of the $\mathrm{x}$-axis. This axis captures the idea, as Lieutenant Colonel David Galula puts it, that "The insurgent $[\ldots]$ has to grow in the course of the war from small to large, from weakness to strength, or else he fails. The counterinsurgent will decline from large to small, from strength to weakness, in direct relation to the insurgent's success." ${ }^{343}$ Likewise, Mao Tse-tung advances a similar idea that an insurgency "must start from nothing and grow." ${ }^{344}$ The primary y-axis depicts the probabilistic chance, ranging from zero to one, that the state can defeat an insurgency in a given period of time. The secondary y-axis on the right-hand side of the figure depicts the probabilistic chances, again ranging from zero to one, that the rebel group will defeat the state.

\footnotetext{
${ }^{343}$ David Galula, Counterinsurgency Warfare: Theory and Practice (Westport: Praeger Security International, 2006), 4.

${ }^{344}$ Mao Tse-tung, cited in, Gordon H. McCormick, Steven B. Horton, and Lauren A. Harrison, "Things Fall Apart: The End Game Dynamics of Internal Wars," Third World Quarterly, Vol. 28, no. 2 (2007), 321-367.
} 
The solid curve in Figure 5.1 depicts the relationship between a rebel group's mobilization of popular support and the odds that the insurgency can successfully defeat the state in a given period of conflict. The relationship is positive with a non-linear slope. What this basically means is that the more popular support an insurgency mobilizes, the greater the chances that the rebel group can defeat the regime. More popular support improves the rebel group's odds of winning because a more powerful insurgency is typically better able to destroy both the material and political assets of the state and thereby obtain victory. In this sense, an insurgent group wins by mobilizing enough capacity to effectively challenge the state, which is consistent with the general concept of rebel group success used throughout this work. The relationship between an increasingly capable and well-supported rebellion and the defeat of the state is likely non-linear because regimes often tend to collapse in a rapid cascade rather than dwindling away at a steady rate. ${ }^{345}$

Clearly, the idea that an insurgency wins by simply mobilizing enough capacity relative to the state to be able to destroy its adversary is a fairly blunt explanation of rebel group success. While not particularly nuanced, this explanation is accurate in some measure as a continually growing rebel group should eventually win, just so long as it does not first lose. As Henry Kissinger put it during the Vietnam War, "We lost sight of one of the cardinal maxims of guerrilla war: the guerrilla wins if he does not lose. The conventional army loses if it does not win." ${ }^{346}$ Similarly, Jeffrey Record posits that, "The insurgent can win simply by not losing, whereas the counterinsurgent power can lose by

\footnotetext{
${ }^{345}$ Theodore McLauchlin, "Loyalty Strategies and Military Defection in Rebellion," Comparative Politics, Vol. 42, no. 3 (April 2010), 333-350; Gordon H. McCormick, Steven B. Horton, and Lauren A. Harrison, "Things Fall Apart: The Endgame Dynamics of Internal Wars," Third World Quarterly, Vol. 28, no. 2 (2007), 321-367.

${ }^{346}$ Henry Kissinger, "The Viet Nam Negotiations," Foreign Affairs, Vol. 47, no. 2 (1969), 214.
} 
not winning. ${ }^{347}$ The mobilization and conflict outcome theory offers few direct insights into the factors that could improve a rebel group's odds of beating the state for a given level of mobilized popular support. It simply maintains that more capable rebel groups are, everything else being equal, more likely to win than less capable groups.

In Figure 5.1, the step-like curve shows the relationship between an insurgent group's ability to mobilize popular support, the organizational and administrative requirements of effective mobilization at that particular level, and the state's ability to defeat the insurgency. The curve is punctuated to show that an insurgency of a particular form can only mobilize so much popular support before it needs to reform either administratively (by increasing the scale of its presence) or organizationally (by centralizing its organization). Such reforms, as noted in chapter 3, improve its ability to mobilize popular support. However, these reforms also, as noted in chapter 4, favour the state by increasing its vulnerability to state military activity and decreasing its ability withstand being targeted by regime forces. Thus, there is an immediate and rapid increase in the state's odds of winning after each reform is undertaken, which is captured by the vertical portion of the curve. This is followed by a plateau (horizontal portion) as the rebel group mobilizes more support through its more productive and efficient structure, which continues until it needs to reform again to grow larger still.

The dashed reaction curve that is shaped like an inverted- $\mathrm{U}$ depicts a smoothed out trend line of the relationship between a rebel group's mobilization of popular support and the odds of state success. Overall, what this means in more general terms is that, everything else being equal, a movement to the right along the $x$-axis, insofar as it necessitates organizational centralization and an increase in the scale of the rebel

347 Jeffrey Record, Beating Goliath: Why Insurgencies Win (Washington: Potomac Books, Inc., 2009$), 13$. 
group's administrative presence, is likely to cause clear movement upwards along the primary y-axis. In other words, up to a certain point, as an insurgency mobilizes popular support and becomes relatively more capable, the odds that the state can defeat the insurgency go up.

This process of a rebel group growing relatively stronger even while the state's odds of defeating the insurgency improve continues until the insurgency becomes stronger than the state. As noted in chapter 4, the negative effects of both organizational centralization and a large-scale administrative presence on the resilience and vulnerability of an insurgency are conditional upon the strength of an insurgent group relative to the forces of the counterinsurgency in the conflict area. Once an insurgency's capacity eclipses that of the state, a rebellion with a large-scale administrative presence and a high degree of organizational centralization is strong enough to reduce its vulnerability by deterring offensive action by the regime and powerful enough to compensate for its lack of inherent organizational resilience through greater strength. As a result, the odds that the state can defeat the insurgency decline, even as the insurgency continues to mobilize higher levels of popular support, which might well necessitate even further centralization and an even larger expansion in the scale of the group's administrative presence.

Two examples should help to clarify how a rebel group's mobilization of popular support affects the potential outcome of a conflict period according to the above framework. There are three possible outcomes to any given period of conflict interaction: the state wins, the rebel group wins, or both the insurgency and the state continue on into the next period of interaction scathed but unbeaten. Imagine, for instance, that a rebel group has mobilized $\mathrm{T}^{1}$ amount of capacity within the country, as it is depicted in Figure 
5.1. At this level of mobilization, the insurgent group has a fairly negligible chance of defeating the state. Tracing upwards from $\mathrm{T}^{1}$ to the intersection with the solid rebel success curve and across to the secondary y-axis gives you a potential rebel group success probability of around 5 percent. Tracing upwards from point $\mathrm{T}^{1}$ to the dashed state success curve and across to the primary y-axis gives you a state success probability of around 50 percent. Since the probability of state success, rebel group success and persistence into the next period have to add up 1, the difference between the combined odds that one or the other side will win and 1 denotes the probability that the conflict will simply continue. In this example, at point $\mathrm{T}^{1}$ the odds that the conflict will simply continue on are at around 45 percent. The most likely outcome to this conflict period, therefore, is that the state will win ( $50 \%$ chance), followed by both sides persisting into the next period of conflict ( $45 \%$ chance), with the rebel group's chances of victory coming last (only 5\%).

Now, imagine that the insurgency has survived this initial period, and likely several others, and has now mobilized $\mathrm{T}^{\mathrm{x}}$ worth of capacity relative to the state as it is depicted in Figure 5.1. If we replicate the process employed above, the insurgency's chances of defeating the state in this period have increased to around 40 percent. The state's odds of winning have also increased to around 55 percent, although they have declined from the previous highs at the apex of the state's success curve. The odds that both sides can simply persist into the next conflict period, meanwhile, have declined to around 5 percent. In the end, even though the insurgency has mobilized more than 50 percent of the total capacity in the country, its odds of winning are only now begin to converge with the state's chances of success, which goes to show the inherent advantage 
that incumbents usually have over challengers. Indeed, tracing to the right along the insurgent group's solid success function, the insurgency's chances of winning eventually surpass the state's and eventually approach 100 percent as some very high level of relative mobilized capacity.

The framework for understanding the interrelationship between a rebel group's mobilization of popular support (manifest in theory as relative capacity and measured in practice as the insurgency's relative share of troops in the country) and the odds that either the state or the insurgency can win or that both parties will simply persist into the next period is clearly scalable. In one sense, the framework can be applied at the macro level, with the country in question taken as a unit of analysis. At this level of analysis, the predicted likelihood of any given outcome would speak to the overall outcome of the campaign. Yet the framework could also be applied at a sub-national level, potentially at the regional, provincial, or some other form of local level. The same general mechanics should be in operation in every case, and, since the model is scaleable, it is useful for understanding not just the final conclusion of the conflict, but also the ebb and flow of the numerous conflict cycles that lead to that more final outcome.

In summary, I have argued that as an insurgent group mobilizes popular support, its chances of defeating the state in a given period of interaction increase. Paradoxically, however, to the extent that mobilization necessitates organizational centralization and an expansion of a rebel group's administrative presence, an insurgent group's mobilization of higher levels of popular support also increases the odds that the state can defeat the insurgency, at least up to a certain point. 


\section{2 - If the theory is correct, what should we expect to see across multiple insurgencies?}

In this subsection, I derive three hypotheses from the baseline framework and test them against data from two large-n dataset: the Correlates of Insurgency and How Insurgencies End. $^{348}$

In conducting these tests, I impose a strict assumption on the data, namely, that the country exists in a condition of autarky, which can be defined as a closed-system that is totally reliant on its own resources. ${ }^{349}$ In such a system, both the state and the insurgency obtain capacity from the same pool of resources, which is nominally held by the population of the country. Under this condition of autarky, the insurgency receives no assistance from external sources, such as states or diaspora groups, and cannot access international markets to sell illicit crops or lootable natural resources. Likewise, the state is only able to draw upon the resources within the country and does not receive arms or other material assistance from other states, although this element of the assumption of autarky is far less important in many ways as states always hold an initial material advantage over the insurgency even without any external assistance. ${ }^{350}$

This is an important assumption to make when testing the initial plausibility of the theory because the condition of autarky strips away other factors (external support for an

\footnotetext{
${ }^{348}$ For the first presentation of the Correlates of Insurgency, see Jason Lyall and Isaiah Wilson III, "Rage Against the Machines: Explaining Outcomes in Counterinsurgency Warfare," International Organization, Vol. 63, no. 1 (2009), 67-106; For the first analysis using the How Insurgencies End dataset, see Ben Connable and Martin C. Libicki, How Insurgencies End (Santa Monica: RAND Corporation, 2010). ${ }^{349}$ This definition is adapted from trade theory. In particular, Michael Todaro and Stephen Smith define autarky as: "a closed economy that attempts to be completely self-reliant." See, Michael Todaro and Stephen Smith, Economic Development, 10th ed., (Toronto: Pearson, Addison Wesley, 2009), 819. ${ }^{350}$ For the idea that the withdrawal of state support to a state can produce a positive outcome for an insurgency, see Timothy P. Wickham-Crowley, Guerrillas \& Revolution in Latin America: A Comparative Studies of Insurgents and Regimes since 1956 (Princeton: Princeton University Press, 1992), 312.
} 
insurgency) that have a measurable effect on conflict outcome. Additionally, the autarky assumption helps to make the rebel group's share of the total mobilized manpower in a country a viable proxy for its overall level of mobilized popular support, which is useful for the empirical testing that is to follow. When external support is present, the number of mobilized insurgents is not a very good measure of the extent of popular support that a rebel group controls, since material and human support for external sources can have a significant effect on an insurgency's fighting strength. For example, in the Vietcong case, of the 3,500 individuals that were mobilized per week in 1968 , some 35 percent $(1,225)$ came from North Vietnam rather than from domestic sources in the South. ${ }^{351}$

When the focus is strictly placed on the idea that a rebel group's mobilization of popular support favours the state's efforts to destroy an insurgency, three predictions can be derived from the theoretical baseline. First, under autarkic conditions, where the insurgency cannot obtain resources from outside of the conflict zone and needs to mobilize popular support in order to grow stronger, the state should almost always win. The second prediction is that as long as the insurgency remains weaker than the state (that is, as long as the insurgency controls less than roughly 50 percent of the total mobilized capacity in the conflict area), the relationship between higher levels of insurgent group capacity and state success should be positive. In other words, as the insurgency gets stronger, but is not yet stronger than the regime itself, the state should win more often as the rebel group's strength improves. Finally, the baseline framework indicates that the state's odds of defeating an insurgency should go up as an insurgent group mobilizes more capacity because the 'typical' rebel group is often compelled to

\footnotetext{
${ }^{351}$ Richard Shultz, "Coercive Force and Military Strategy: Deterrence Logic and the Cost-Benefit Model of Counterinsurgency Warfare," Political Research Quarterly, Vol. 32, no. 4 (1979), 460.
} 
centralize its organization and expand its administrative presence in order to mobilize the highest possible level of popular support. As a result, it is reasonable to predict that the rebel groups that have the largest absolute amount of mobilized capacity should be predominantly centralized organizations with a large-scale administrative presence. The smallest rebel groups, in contrast, should be more decentralized with a smaller administrative presence, everything else being equal. Below, I first describe the datasets that I use to test the three derivative hypotheses. Then, I test each ancillary hypothesis against this data and find admittedly tentative, yet generally supportive, evidence for each.

\subsection{1 - The Datasets}

The Correlates of Insurgency first appeared in 2009 and was constructed by Jason Lyall and Isaiah Wilson III. ${ }^{352}$ Lyall and Wilson III define an insurgency as "a protracted violent struggle by nonstate actors to obtain their political objectives — often independence, greater autonomy, or subversion of existing authorities — against the current political authority (the incumbent)." ${ }^{353}$ The authors included only those conflicts that met a minimum threshold of battle deaths (1,000 total and at least 100 per side) and restricted the sample to only those conflicts where the insurgency used guerrilla warfare tactics. ${ }^{354}$ These coding procedures yielded a total of 286 conflicts between the year 1800 and the year 2005. These data are generally compatible with the definition of insurgency used in this study, with only two divergent elements. First, Lyall and Wilson did not

\footnotetext{
${ }^{352}$ See Jason Lyall and Isaiah Wilson III, "Rage Against the Machines: Explaining Outcomes in Counterinsurgency Warfare," International Organization, Vol. 63, no. 1 (2009), 67-106.

${ }^{353}$ Ibid., 70.

${ }^{354}$ Ibid.,
} 
specify that the group needed to try and control territory. Second, my study does not rely upon an explicit minimum casualty threshold in order for an insurgency to be counted as such. These small differences should not bias the results of the tests, making this dataset a good source of empirical data for my own study.

The How Insurgencies End dataset was compiled and analysed by Ben Connable and Martin C. Libicki. ${ }^{355}$ Connable and Libicki began the construction of their dataset by using a dataset first assembled by James D. Fearon and David D. Laitin. ${ }^{356}$ In their dataset, Fearon and Laitin included insurgencies that met three criteria: 1) there was a conflict between the state and a nonstate actor whose aim was to obtain control of the government, secede, or reform current policy; 2) the conflict had to have a minimum of 1,000 casualties and an average per year of 100 casualties; 3 ) of the total number of casualties, 100 had to be suffered by each side. ${ }^{357}$ These initial coding efforts yield 127 conflicts up to 1999. Connable and Libicki added 11 conflicts that occurred after 1999 that still met Fearon and Laitin's three basic rules for inclusion. They also excluded 51 others that were not well characterised as insurgencies. As Connable and Libicki put it, "We tended to omit conflicts that would shed little light on our key question of how insurgencies end. Many of these are closer in nature to civil disturbances, coups, and coup attempts, or spontaneous insurrections. Of the 51 [excluded], almost half (25) did not see their second birthday, and all but nine of them ended within six years." ${ }^{358}$ Given these new inclusions and exclusions, Connable and Libicki are left with 89 insurgencies

\footnotetext{
${ }^{355}$ See Ben Connable and Martin C. Libicki, How Insurgencies End (Santa Monica: RAND Corporation, 2010).

${ }^{356}$ James Fearon and David Laitin, "Ethnicity, Insurgency, and Civil War," American Political Science Review, Vol. 97, no. 1 (2003), 75-90.

${ }^{357}$ Ibid., 76.

${ }^{358}$ Ben Connable and Martin C. Libicki, How Insurgencies End (Santa Monica: RAND Corporation, 2010), 199.
} 
that began between 1934 and 2004. Again, the How Insurgencies End dataset has many strong similarities to the definition of insurgency used in my study, with the only real theoretical exception being that Connable and Libicki maintain a minimum casualty threshold while I do not - or at least I do not do so in any formal way. Additionally, the How Insurgencies End and the Correlates of Insurgency datasets are generally comparable with each other, although each includes a variety of different independent variables.

\subsection{2 - Hypothesis 1: The State Should Almost Always Win}

The state should win most of the time under autarky because a rebel group often has to adopt high levels of organizational centralization and a large scaled administrative in order to mobilize high levels of popular support. As an insurgency adopts these characteristics, it increases its vulnerability and undermines its organizational resilience to state military activity. Thus, under autarky, as a rebel group attempts to mobilize enough popular support to defeat the state, the chances that the state can defeat the insurgency increase even as the rebellion's capacity relative to the regime also rises. What this means, in other words, is that most insurgent groups should be beaten by the state when the rebellion can only rely upon the population of a country as its source of capacity augmenting support. As Jeffrey Record puts it, "One has difficulty finding a successful, externally unassisted insurgency, except in those cases of exceptionally weak or disintegrating governments." ${ }^{359}$

Figure 5.2 presents descriptive data on 187 insurgencies that lacked an international patron to test the hypothesis that, semi-autarkic conditions, insurgent groups

359 Jeffrey Record, Beating Goliath: Why Insurgencies Win (Washington: Potomac Books, Inc., 2009), 64. 
should usually lose. The data for this figure is drawn from Jason Lyall and Isaiah Wilson III's dataset, Correlates of Insurgency. ${ }^{360}$ The Figure includes all conflicts between 1800 and 2002 where the insurgency did not have an international patron, which is not to say that the rebel group did not receive support from other sources or that the state was not supported by another state or international organization. In this sense, the insurgencies in this sample exist in some semi-autarkic conditions. Lacking in external state support, the rebel groups in this sample could only challenge the state by mobilizing popular support from within the country (although some had access to international markets and fewer still had access to overseas diaspora networks). Excluding insurgent groups that received external support helps to approximate the condition of autarky, which provides the clearest picture of the hypothesized effects.

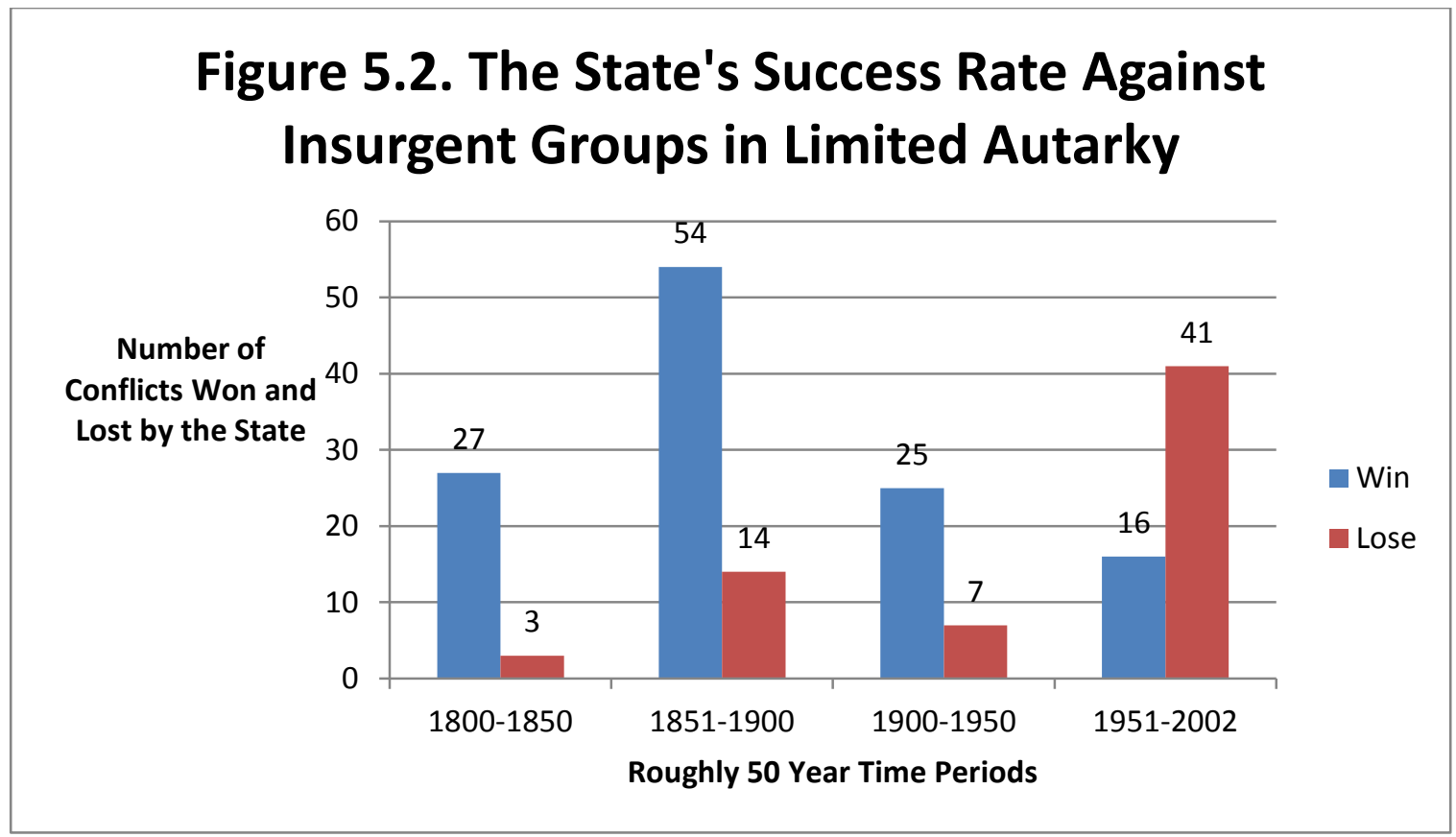

As the data in Figure 5.2 illustrates, during the 202-year period from 1800 to 2002, the state won 122 of the 187 conflicts. This figure translates over into a state

\footnotetext{
${ }^{360}$ Jason Lyall and Isaiah Wilson III, "Rage Against the Machines: Explaining Outcomes in Counterinsurgency Warfare," International Organization, Vol. 63, no. 1 (2009), 67-106.
} 
success rate of 65 percent. Given that a multitude of other factors, particularly insurgent access to international markets or diaspora groups, are not controlled for in these cases, the finding that the state wins an easy majority of cases when no international patron provided material support to the insurgency is, at the very least, tentatively supportive of the mobilization and conflict outcome theory. Under what could be dubbed semi-autarkic conditions, the state stands a fairly good chance of beating the insurgency over the 202 years in this sample.

Focusing in on just the 150 year period before 1950, where international trade and international capital flows were far less than in the 1950-2002 period, the state defeated insurgent challenges that lacked an international patron some 82 percent of the time. Despite the period of increasing world trade that occurred from the 1870 s to the early 20th century, this timeframe more aptly conforms to the assumption of autarky, as rebel groups during this 150 years period likely had less access to international markets or diaspora support than insurgent groups from 1950 to 2002. That the state won a significant majority of conflicts during this time provides fairly robust support for the hypothesis that the state should almost always win under autarkic conditions.

Moreover, generally speaking, the further back in time you go, the more closely the conflict in question is likely to resemble genuinely autarkic conditions, where an insurgency is only able to obtain capacity by mobilizing popular support within the country. As expected, the further back in time the observation is made, the higher the chances that the state wins the conflict, which is again strongly supportive of the derivative hypothesis. From 1901 to 1950, for example, insurgent groups lost to the regimes that they were challenging some 78 percent of the time. From 1851 to 1900 , the 
state won 79 percent of the time. Finally, during the oldest period, 1800 to 1850 , the state defeated 90 percent of insurgent challengers that lacked an international patron. The fact that state success increases as the likelihood of autarkic conditions increases strongly suggests that the theoretical baseline statement of the mobilization and conflict outcome theory, which posits that states under autarky should almost always win, is accurate in some measure.

The trends in state success are suggestive of the validity of the theory developed here. The alternative conceptualization that the relationship between popular support for an insurgency and state success is inherently linear and negative would also predict that, under autarky, the state should win most of the time. As such, the tests conducted in this section are in no way definitive proof of the theory, even if they are suggestive. The test conducted here is a "certain" one, even though it is not unique. ${ }^{361}$ A more crucial test is what the relationship between a rebel group's mobilized capacity, that is, popular support for an insurgency, and conflict outcome really is under autarky.

\subsection{3 - Hypothesis 2: The Relationship between A Rebel Group's Mobilized Capacity and State Success Should be Positive so Long as the Insurgency is Weaker}

The second prediction that can be derived from the theoretical baseline is that the relationship between growing insurgent group capacity relative to the state and the odds that the state can beat the insurgency should be positive. In other words, insurgencies that are growing in strength should be more likely to lose. This notion is exactly opposite to

\footnotetext{
${ }^{361}$ Stephen Van Evera, Guide to Methods for Students of Political Science (Ithaca: Cornell University Press, 1997), 31.
} 
the idea that more popular support is always a good thing for an insurgency, making this a "certain" and "unique" prediction of the mobilization and conflict outcome theory. ${ }^{362}$

To test this hypothesis, I operationalize popular support for an insurgency as the relative share of total mobilized capacity within the conflict zone controlled by the insurgency at its peak strength. In other words, I operationalize popular support for an insurgency as the absolute size of the rebel group divided by the total mobilized capacity (insurgent group size plus the state's forces) in the conflict zone. Since a rebel group's ability to obtain a peak size, especially under autarkic conditions, depends upon their ability to produce enough popular support-securing outputs to grow their membership, the measure of a rebel group's share of the total mobilized capacity in the conflict zone at its peak strength likely results from the extent of an insurgency's organizational centralization and the scale of its administrative presence. Using the relative measure also accommodates the variable absolute size of both rebel groups and state forces, which also facilitates comparisons across cases. As noted in the introductory chapter, this particular measure is far less accurate as a proxy for a rebel group's mobilized level of popular support under non-autarkic conditions.

Table 5.1 lists 11 conflicts since 1950 where the insurgency did not have international support. The data on these conflicts are drawn from Ben Connable and Martin C. Libicki's dataset, How Insurgencies End. ${ }^{363}$ I test this hypothesis against only the one dataset because the Correlates of Insurgency lacked data on insurgent troop levels. I made six changes to the original data. First, I removed the CCP in China from the list of insurgencies that did not receive international support, as they did receive

\footnotetext{
362 Ibid.,

${ }^{363}$ Ben Connable and Martin C. Libicki, How Insurgencies End (Santa Monica: RAND Corporation, 2010).
} 
assistance at various times from the Soviet Union. ${ }^{364}$ Second, I added the Mau Mau's in Kenya to the list of groups that did not have international sponsorship and revised the size of the insurgency downwards from the mistaken level of 120,000 to the far more reasonable level of $15,000 .^{365}$ Third, I revised the size of the MCP in Malaya downwards from a peak size of 15,000 to $8,200 .{ }^{366}$ Since both of these insurgencies lost, the lower troop levels in both cases actually works against the hypothesis. Fourth, I revised the number of Shining Path guerrillas upwards from 5,000 to $10,000 .^{367}$ Estimates of the Shining Path's peak strength vary, with some reaching as high as $23,000 .^{368}$ Given that Sendero Luminoso lost the conflict, I used the lower number as this works against my hypothesis that a rebel group's mobilization of high levels of support favours state success. Fifth, I recoded conflict outcome into a dichotomous variable. ${ }^{369}$ State success now includes both the unambiguous cases of state victory and more mixed outcomes. Insurgent success now includes both outright rebel group success and ongoing insurgencies. Finally, the How Insurgencies End dataset was published in 2009 and some conflicts that were ongoing at that time have now ended. I updated the outcome of this

\footnotetext{
${ }^{364}$ See, Jeffrey Record, Beating Goliath: Why Insurgencies Win (Washington: Potomac Book, Inc., 2009), 38-44.

${ }^{365}$ For the revised estimate on the size of the Mau Mau, see Kenneth W. Grundy, Guerrilla Struggle in Africa: An Analysis and Preview (New York: Grossman Publishers, 1971), 81.

${ }^{366}$ John Coates, Suppressing Insurgency: An Analysis of the Malayan Emergency, 1948-1954 (Boulder: Westview Press, 1992). Data on the estimated size of the insurgency is found on page 76, footnote 76.

${ }^{367}$ The estimate of 10,000 guerrillas is taken from Cynthia McClintock, Revolutionary Movements in Latin America (Washington: United States Institute of Peace Press, 1998), 73.

368 James F. Rochlin, Vanguard Revolutionaries in Latin America: Peru, Colombia, Mexico (Boulder: Lynne Rienner Publishers, 2003), 39.

${ }^{369}$ I coded the outcome to these internal conflicts as a dichotomous variable to facilitate the empirical testing. The difficultly with the previous measure was that there was no clear way to ordinally rank conflict continuation, insurgent success, mixed outcomes and state success. Using a dichotomous ranking allows for the clearest analysis of the basic trend in the data.
} 
conflict to correspond with the dichotomous coding of outcomes as either state success or failure. $^{370}$

Table 5.1 includes data on the peak size of the insurgency in each case, data on the size of the state's forces (mainly the military either nationally or locally depending upon the geographical distribution of the insurgency), the summed total mobilized capacity within the conflict area, and the insurgent group's relative share of that total. Two of the conflicts in the sample, Sierra Leone and Peru, are clear instances where lootable natural resources or illicit crops, respectively, played a significant role in financing the insurgency. To generate the largest sample possible, I include both cases in the initial round of analysis below. I also test the relationship between a rebel group's relative share of total mobilized capacity within the conflict zone and state success without these cases. The results are consistent across both samples.

\begin{tabular}{|c|c|c|c|c|c|}
\hline \multicolumn{7}{|c|}{ Table 5.1. Insurgencies without External Support } \\
\hline Conflict & $\begin{array}{c}\text { State } \\
\text { Wins }\end{array}$ & $\begin{array}{c}\text { Insurgent } \\
\text { Peak Size }\end{array}$ & $\begin{array}{c}\text { State Size } \\
\text { (mainly } \\
\text { armed } \\
\text { forces) }\end{array}$ & $\begin{array}{c}\text { Total } \\
\text { Mobilized } \\
\text { Capacity }\end{array}$ & $\begin{array}{c}\text { Insurgent } \\
\text { Group's } \\
\text { Relative } \\
\text { Share of Total } \\
\text { Capacity }\end{array}$ \\
\hline $\begin{array}{c}\text { Kenya, 1946- } \\
\text { 1955 }\end{array}$ & Yes & 15,000 & 55000 & 70000 & 0.21 \\
\hline $\begin{array}{c}\text { Philippines } \\
\text { HUK, 1946- } \\
\text { 1955 }\end{array}$ & Yes & & & & \\
\hline $\begin{array}{c}\text { Malaya, } \\
\text { 1948-1960 }\end{array}$ & Yes & 8,200 & 28,000 & 36,200 & 0.23 \\
\hline $\begin{array}{c}\text { Cuba, 1953- } \\
\text { 1959 }\end{array}$ & No & 700 & 35,000 & 35,700 & 0.02 \\
\hline $\begin{array}{c}\text { Uruguay, } \\
\text { 1963-1973 }\end{array}$ & Yes & 4,000 & 34,000 & 38,000 & 0.11 \\
\hline $\begin{array}{c}\text { Balochistan, } \\
\text { 1973-1977 }\end{array}$ & Yes & 12,000 & 80,000 & 92,000 & 0.13 \\
\hline
\end{tabular}

\footnotetext{
${ }^{370}$ I ran the statistical tests below on the original sample. The direction of the relationship is the same and only the size of the $R^{2}$ changes.
} 


\begin{tabular}{|c|c|c|c|c|c|}
\hline $\begin{array}{c}\text { Peru, 1981- } \\
1992\end{array}$ & Yes & 10,000 & 120,000 & 125,000 & 0.08 \\
\hline $\begin{array}{c}\text { Sierra Leone, } \\
1991-2002\end{array}$ & Yes & 6,000 & 13,000 & 19,000 & 0.32 \\
\hline $\begin{array}{c}\text { Algeria } \\
\text { (GIA), 1992- } \\
2004\end{array}$ & Yes & 10,000 & 160,000 & 170,000 & 0.06 \\
\hline $\begin{array}{c}\text { Nigeria } \\
\text { (Niger Delta), } \\
\text { 1991- } \\
\text { present }\end{array}$ & No & & & & \\
\hline $\begin{array}{c}\text { Darfur, 2003 } \\
\text { - present }\end{array}$ & No & 10,000 & 40,000 & 50,000 & 0.03 \\
\hline
\end{tabular}

The 11 cases in the sample include all the insurgencies from the How Insurgencies End dataset where the insurgency both lacked international support and controlled less than 50 percent of the total mobilized capacity within the country. Limiting the sample to only those insurgencies that lacked international support helps to approximate the assumption of autarky, where the relationship between a rebel group's relative capacity and state success should be most apparent. Moreover, since the mobilization and conflict outcome theory suggests that the negative effects of both a rebel group's organizational centralization and its large-scale administrative presence are conditional upon the relative strength of the state and the insurgency, I have excluded cases where the insurgency controlled a majority share (anything at 50 percent or greater) of the capacity within the country.

Figure 5.3 plots the relationship between an insurgent group's share of the total mobilized capacity within the conflict zone against state success, both including and excluding the conflicts where the sale of natural resources or illicit crops helped to finance the rebellion. The independent variable of interest, $\mathrm{x}$, is the insurgent group's relative share of the total mobilized capacity within the conflict area, which, under 
generally autarkic conditions, is a proxy for the amount of popular support that the insurgency is able to mobilize. The dependent variable, $y$, is a measure of the state's success (2) or failure (1). The logarithmic trend lines point out both the direction and the $\mathrm{R}^{2}$ of the relationship between $\mathrm{x}$ and $\mathrm{y}$ in each sample. As the theory suggests, under autarkic conditions and with the insurgency controlling less than 50 percent of the total mobilized capacity within the country, the relationship between the insurgency's relative share of mobilized capacity and conflict outcome is positive. In other words, an increase in a rebel group's realized level of popular support results in an increase in state success.

The 'No External Support' sample in Figure 5.3 includes Peru and Sierra Leone, where access to international markets helped the rebel group grow in capacity through the sale of illicit crops and lootable natural resources, respectively. The $\mathrm{R}^{2}$ in this series is 0.3348 , which essentially means that about 34 percent of the variation in the dependent variable, state success, is being explained by the insurgent group's relative share of the total mobilized capacity within the country. The baseline theoretical framework suggests that the positive relationship between the insurgent group's relative share of mobilized capacity within the country and state success should be more pronounced the closer the assumption of autarky is to being satisfied. The 'Pure Autarky' sample excludes Peru and Sierra Leone. The relationship between an insurgent group's share of the total mobilized capacity within the country and state success remains positive. Additionally, as the theoretical baseline suggests, the amount of variation in state success that higher levels of rebel group relative capacity explains increases when more autarkic conditions hold sway, with the $\mathrm{R}^{2}$ increasing to 0.3506 . 




The positive relationship between the rebel group's share of total mobilized capacity within a conflict zone and state success remains even if the assumption of autarky is relaxed and the sample is expanded to include all 21 rebel groups in the How Insurgencies End dataset that had either no, some, or little international support and less than 50 percent of the mobilized capacity. ${ }^{371}$ In this somewhat larger sample, as outlined in Figure 5.4, rebel groups with higher levels of mobilized capacity are, once again, more likely to be defeated than weaker groups. Under even semi-autarkic conditions, the capacity of the insurgency is at least partially derived from the population. As such, this finding indicates that the relationship between popular support for an insurgency and state success is positive as long as the insurgency is weaker than the state. In other words, rebel groups that mobilize more popular support, but that still remain weaker than the state, are more likely to lose the stronger they get. Indeed, the relationship between

\footnotetext{
${ }^{371}$ The expanded sample includes the original 11 insurgencies outlined in Table 5.1 as well as the MNLF in the Philippines, Indonesia (Aceh), Burma, Morocco, Philippines (MILF), Liberia, Mozambique (RENAMO), Congo (anti-Kabila), Nepal, and South Thailand. Some of the entries in the original dataset listed the source of the support rather than giving any intimations about the scale of that support. For example, that support came from the Soviet Bloc or NATO countries. These cases were excluded and only those cases where support was identified as being fairly minimal in scale were included in Figure 5.4.
} 
growing popular support and state success is likely stronger than the larger sample indicates, since at least a portion of the insurgency's capacity in many of the cases in the sample is derived from external sources and not from the population. ${ }^{372}$



These tests are indicative of the generalizability of the theory, but are certainly not definitive. In this case, the small size of the sample makes the results highly prone to the value of any individual observation, particularly in the 'No External Support' and 'Pure Autarky' samples. Additionally, the lack of controls makes generalization on the basis of these data problematic, although some important characteristics are controlled for through sample truncation on the key independent variables of external support and the rebel group's relative share of mobilized capacity. Likewise, while the mobilization and conflict outcome theory posits a clear explanation for why the relationship between relatively more capable insurgencies and state success would be positive and why the

\footnotetext{
${ }^{372}$ When the autarky assumption is completely dropped and the same tests are run on the whole sample of 71 insurgencies in the How Insurgencies End dataset, the relationship between a rebel group's mobilization of capacity relative to the state and state success remains positive, although the $R^{2}$ drops to 0.0024 . Since an insurgency's troop levels can be inflated by foreign fighters and is likely a function of how many guns a group has, which would be increased by external support, rebel group troop levels is not a very strong proxy for the concept of mobilized popular support when external actors play a role in the conflict on behalf of an insurgency.
} 
closer the conditions are to general autarky the more pronounced the relationship should be, it is not possible to say definitively that the proposed mechanisms are necessarily at work without in-depth analysis of each particular case. It is also possible, for example, that insurgent groups that control a small share of the total mobilized capacity within the country are simply not worth beating and that as the group grows stronger the state tries harder to win. ${ }^{373}$ Nevertheless, the prediction that a rebel group's increased mobilization of popular support should be positively related to state success is both a "certain" and a "unique" prediction of the mobilization and conflict outcome theory. ${ }^{374}$ That the theory passes this test is certainly supportive of the theory, despite the limitations noted above.

\subsection{4 - Hypothesis 3: High Levels of Absolute Mobilization Require Centralization and an Expansion of a Rebel Group's Administrative Presence}

In this section, I test the final hypothesis that I derived from the baseline framework.

Below, I first restate the core hypothesis and its empirically testable parameters.

Following that, I outline how I operationalize insurgent organizational structure, rebel group administrative presence, and what measure I use to proxy for total mobilized popular support in this case. I then test the hypothesis against data from the How Insurgencies End dataset. Again, I only test the hypothesis against a single dataset because data on the organizational structure and administrative presence of the insurgency are not available in the Correlates of Insurgency. Once again, I find roughly supportive evidence for this element of the theory. The data again supports the baseline framework.

\footnotetext{
${ }^{373}$ I am grateful to Theo McLaughlin for this observation.

${ }^{374}$ Stephen Van Evera, Guide to Methods for Students of Political Science (Ithaca: Cornell University Press, 1997), 31.
} 
First, to briefly re-state the hypothesis, the theory suggests that the most popular insurgent groups should be both centralized and have an expanded administrative presence, while decentralized groups with a smaller-scale administrative presence should be generally able to mobilize less popular support, everything else being equal. The empirical implication of this hypothesis is that the rebel groups that command the largest number of guerrillas should be centralized with a large-scale administrative presence. In contrast, rebel groups with a smaller numbers of soldiers should be decentralized with a small scale administrative presence - or at least there should be a healthy diversity of organizational forms at the low end of the guerrilla numbers.

I operationalize rebel group organizational centralization and the scale of a rebel group's administrative presence using two variables from the How Insurgencies End dataset. I operationalize organizational centralization using the dataset's rebel group structure variable, which is essentially a measure of whether an insurgency was organized hierarchically, in a mixed fashion, or as a network. I disagree with some of the coding of individual cases (for instance, I would not code the Mau Mau in Kenya as a "mixed" organization or the MCP in Malaya as a "Hierarchy"). At its root, this disagreement is largely conceptual, as the concepts of hierarchies and networks do not completely overlap with my own conceptualization of organizational centralization and decentralization as a matter of differing degrees of subunit mutual reliance. Nevertheless, and despite some points of disagreement, the variable does generally capture the difference between centralized (hierarchy) and decentralized (network) insurgent groups. In the end, I did not alter any of the observations of the organizational variable because I did not want to 
introduce any subjective measurement error into the coding. ${ }^{375}$ Instead, I have chosen to maintain the current operationalization of the organizational variable used in the original dataset. It is, I believe, close enough to my own conceptualization of organizational centralization and decentralization to allow for good testing. As a result, the tests likely under-represent the magnitude of the relationship and are, in some ways, more valid than if I had coded each case with a particular theory in mind, although this is not to say that coding of this sort cannot also produce sound results.

The operationalization of an expanded rebel group administrative presence is a rather more crude measure. As a proxy for the scale of the rebel group's administrative presence, I used a dichotomous variable for whether the insurgent group tried to hold territory during the conflict. This is a reasonable proxy for an expanded administrative presence. As was noted in chapter 3, as a rebel group expands its administrative presence and assumes control of an area, it displaces the state or incorporates or displaces other pre-existing socio-political organizations. Thus, if a rebel group did not control territory during the conflict, then its administrative presence was probably low. If an insurgent group did control territory during the conflict, then its administrative presence was likely high. Of course, as I return to in more detail below, there is a problem of endogeneity here, as stronger rebel groups might be more likely to control territory rather than the proposed causal relationship which is that those groups that control territory (have a larger administrative presence) are likely to be stronger. Despite its limitations, this measure is, unfortunately, the best one available.

\footnotetext{
${ }^{375}$ On subjective measurement error, see Gary King, Robert O. Keohane, and Sidney Verba, Designing Social Inquiry: Scientific Inference in Qualitative Research (Princeton: Princeton University Press, 1994), 157.
} 
Lastly, I use a slightly different measure as a proxy for the amount of popular support that an insurgent group has successfully organized. In this case, I do not use the insurgent group's relative share of the total mobilized capacity in the country as a metric for how much popular support the group obtains. The relative measure, while theoretically more accurate when looking at conflict outcome (as warfare is an inherently relative business), is a less suitable measure in this case. The problem with the relative measure is that a group could have a very high share of the total mobilized capacity but only a small amount of actual mobilized capacity, provided that the insurgency is facedoff against a weak state. In contrast, a rebel group could have a small share of the total mobilized capacity within the country but could have actually mobilized a large amount of capacity in absolute terms, provided that it is faced-off against a very strong state. The mobilization and conflict outcome theory suggests that to mobilize a lot of people through an exchange relationship may require that an insurgent group organize itself in a centralized way and that it expand its administrative presence in order to produce a lot of popular support-securing outputs in the most efficient way possible. To align best with this theoretical proposition, I use the absolute measure of the total number of troops an insurgent group mobilized during the conflict as a proxy for the amount of popular support that it obtained. This measure avoids the problems of the relative measure, and, in this case, fits the dictates of the theory better.

To test the third derivative hypothesis, I used an expanded version of the "Limited Autarky" sample, which I also used above to test hypothesis 2. The "Limited Autarky" sample includes all 23 conflicts in the How Insurgencies End dataset where the insurgency had no, some, limited, or little international support. Thus, I maintain a weak 
version of the autarky assumption in order to better isolate for the relationship between an insurgent group's efforts at mobilizing popular support and its organizational and administrative form. Unlike the "Limited Autarky" sample used above to test hypothesis 2, the sample used to construct Figure 5.5 and Figure 5.6 also includes those conflicts where the insurgency had mobilized more than 50 percent of the total capacity within the conflict. The conflicts in the sample are clustered into groupings according to the standard deviation (19,500 insurgents) of the entire sample. ${ }^{376}$

Figure 5.5 presents a histogram of the distribution of insurgent groups across the entire "Limited Autarky" sample. As Figure 5.5 shows, the smallest rebel groups in the sample - those under 19,500 insurgents - have a healthy diversity of organizational forms. Hierarchies represent 41 percent of the observations. Mixed organizational forms make up 23 percent. And, lastly, network types organizations make up 35 percent. As the mobilization and conflict outcome theory suggests, more decentralized organizational forms (mixed structures or networks) stop appearing as the absolute size of the insurgent group increases. Of the six insurgent groups that managed to obtain between 19,500 and 39,000 insurgents, only 1 group (or 17 percent of the observations) is a network. The remaining 5 groups (or 83 percent of the observations) are centralized groups. Lastly, the outlier case again fits the proposed pattern, as it too is a hierarchy. While the sample size is limited and the results are descriptive rather than statistical, the outcome of this test nevertheless supports the idea that in order to grow stronger in absolute terms an insurgent group needs to adopt a centralized organizational structure to improve its

\footnotetext{
${ }^{376}$ Running the same procedure excluding the outlier case of the Lebanese Civil War, which shrinks the standard deviation considerably, produces a similar result.
} 
productive efficiency and to obtain more popular support, at least under weakly autarkic conditions. $^{377}$

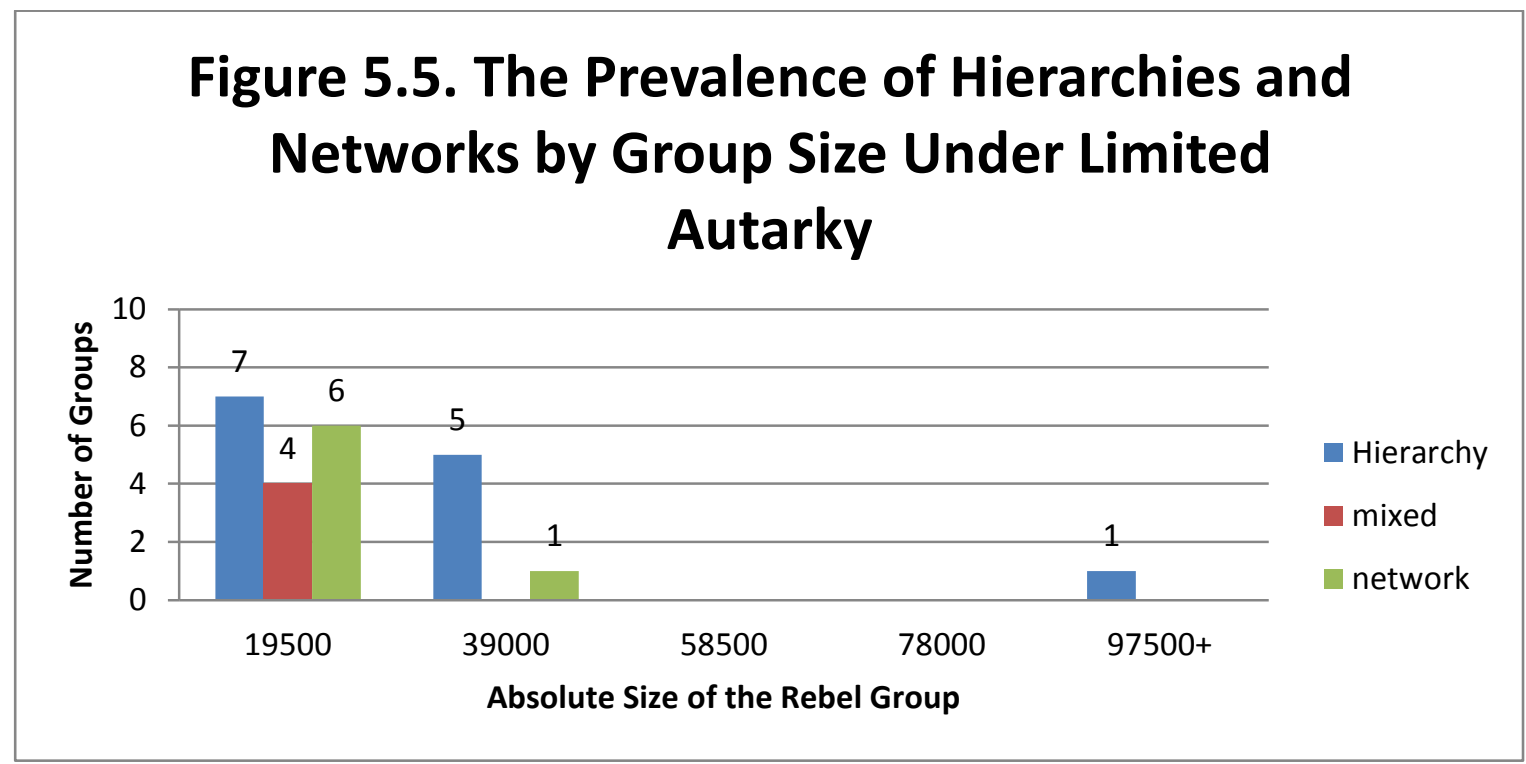

The second part of hypothesis 3 is that a rebel group usually has to expand its administrative presence in order to mobilize high levels of popular support. I tested this element of the proposition, once again, against the expanded "Limited Autarky" sample divided into units of standard deviation. As Figure 5.6 shows, the results are again consistent with the theory. The largest rebel groups are those that have an expanded administrative presence, proxied by the insurgency's efforts to control territory. The smallest insurgent groups have a mixture of both those that controlled territory and those that did not, with those controlling territory making up 76 percent of the observations and those that did not control territory making up the remaining 24 percent. However, above the 19,500 insurgents cut-off, there are no insurgent groups that maintained a large size and did not control territory. This finding suggests that rebel groups do indeed need to

\footnotetext{
${ }^{377}$ Similar results, although they are less pronounced, emerge when the relative capacity measure is used in place of the absolute capacity measure.
} 
expand their administrative presence in order to mobilize higher levels of popular support. ${ }^{378}$



Admittedly, there is a significant potential limitation with interpreting this result as unambiguous support for the hypothesis; namely, endogeneity between the proxy for the independent variable and the dependent variable. For example, it is possible that, rather than having an expanded administrative presence (proxied by a rebel group's control of territory) cause a growth in the absolute size of an insurgent group, a large insurgent group might simply be more likely to control territory. To some extent, the relationship between absolute rebel group size and the proxy of controlling territory likely is endogenous, so the test is imperfect. The mobilization and conflict outcome theory still suggests, however, that the relationship between an expanded insurgent group administrative presence and group size should be distinct and clear and the data contained in Figure 5.6 supports this interpretation, even if the problem of endogeneity cannot be

\footnotetext{
${ }^{378}$ Again, the relationship holds even if the relative capacity measure is used in place of the absolute measure.
} 
discounted. Lagged observations over multiple time periods would be needed to correct for this problem. Unfortunately, the data needed for such a test does not currently exist. In sum, the third derivative hypothesis, namely, that in order to get bigger, a rebel group may need to centralize its organizational structure and expand its administrative presence is tentatively supported by the data from the expanded "Limited Autarky" sample of the How Insurgencies End dataset. Once again, the results are not definitive, although they are indicative of the general validity of the baseline framework.

\subsection{5 - Conclusions}

To test the validity of theoretical baseline, I derived and tested three core implications from the mobilization and conflict outcome theory: 1) the state should defeat insurgent challengers most of the time (a certain but not unique prediction); 2) the relationship between growing popular support for an insurgency and state success should be positive, as long as the insurgency is weaker than the state (a certain and unique prediction); 3) insurgent groups should need to adopt a centralized organization and a large-scale administrative presence in order to reach a large size (a certain and potentially unique prediction). Each of these derived implications was supported by cross-national data, which indicates that the theory is valid in some measure. The theory, of course, also suggests that a multitude of other factors influence the odds that the state can defeat an insurgency and whether an insurgent group has an incentive to reform organizationally and administratively. The next subsection deals with those conditions.

\section{3 - What factors, as suggested by the theory, affect conflict outcome?}


In this section, I start by outlining how a condition can affect the state's success curve. I argue that any condition that allows an insurgent group to mobilize a given level of capacity augmenting popular support with less need for organizational centralization or with a smaller administrative presence favourably affects an insurgency's chance of success by making it harder for the regime to destroy the rebellion. In contrast, conditions that make the mobilization of a given amount of popular support more difficult for a rebellion, and therefore necessitate more organizational centralization and a more expanded administrative presence, improve the odds that the state can win in a given conflict cycle. I then detail the various conditions, as they are contained in the mobilization and conflict outcome theory, that explain why an insurgent group might be more or less likely to win or lose in certain circumstances.

\subsection{1 - Will a Rebel Group Lose Before it Can Win? How Conditions Affect the Slope of the State's Success Reaction Curve}

A condition can affect the outcome of a conflict by either positively or negatively altering the state's odds of destroying an insurgency in a given period. A condition can have a positive effect on state success by pressuring an insurgency into adopting a centralized organizational form and an expanded administrative presence in order to mobilize popular support. A condition can have a negative effect on state success by allowing an insurgency to remain relatively decentralized with a small administrative presence, while still allowing the group to mobilize popular support.

As depicted in Figure 5.7, different conditions can align to alter the slope of the state's success reaction curve, which basically makes the inverted-U-shaped relationship that exists between a rebel group's mobilization of popular support, proxied by the 
insurgency's capacity relative to the regime, and state success more or less pronounced. How pronounced the inverted- $U$ relationship is in any given context depends entirely upon the extent to which an insurgency that is mobilizing popular support through an exchange relationship needs to adopt a higher level of organizational centralization and an expanded administrative presence in order to mobilize enough popular support to effectively challenge the state. A more pronounced inverted-U means that an insurgent group's mobilization of popular support through an exchange relationship necessitates significant organizational centralization and a fairly large expansion of the group's administrative presence. A less pronounced inverted-U shaped relationship, in contrast, means that an insurgent group's mobilization of popular support can be accomplished with relatively less centralization and a smaller scaled administrative presence.

Figure 5.7 heuristically plots a state's success reaction curve under two different set of conditions, which align to generate what I call a rebel group's mobilization context. $^{379}$ I define a rebel group's mobilization context as the alignment of conditions that determine how easy it is for an insurgent group to mobilize a given amount of popular support. In this sense, mobilization involves the return that a group receives on the production of a bundle of popular support-securing outputs, which is composed of some combination of remunerative compensation and preference manipulation tactics.

\footnotetext{
${ }^{379}$ The mobilization context, in the sense that I am using it here, is similar to the political opportunity structure found in Sidney Tarrow, Power in Movement: Social Movements and Contentious Politics (Cambridge: Cambridge University Press, 2011).
} 


\section{Figure 5.7. Rebel Group Relative Capacity and Chance of State Success} Under Variable Conditions

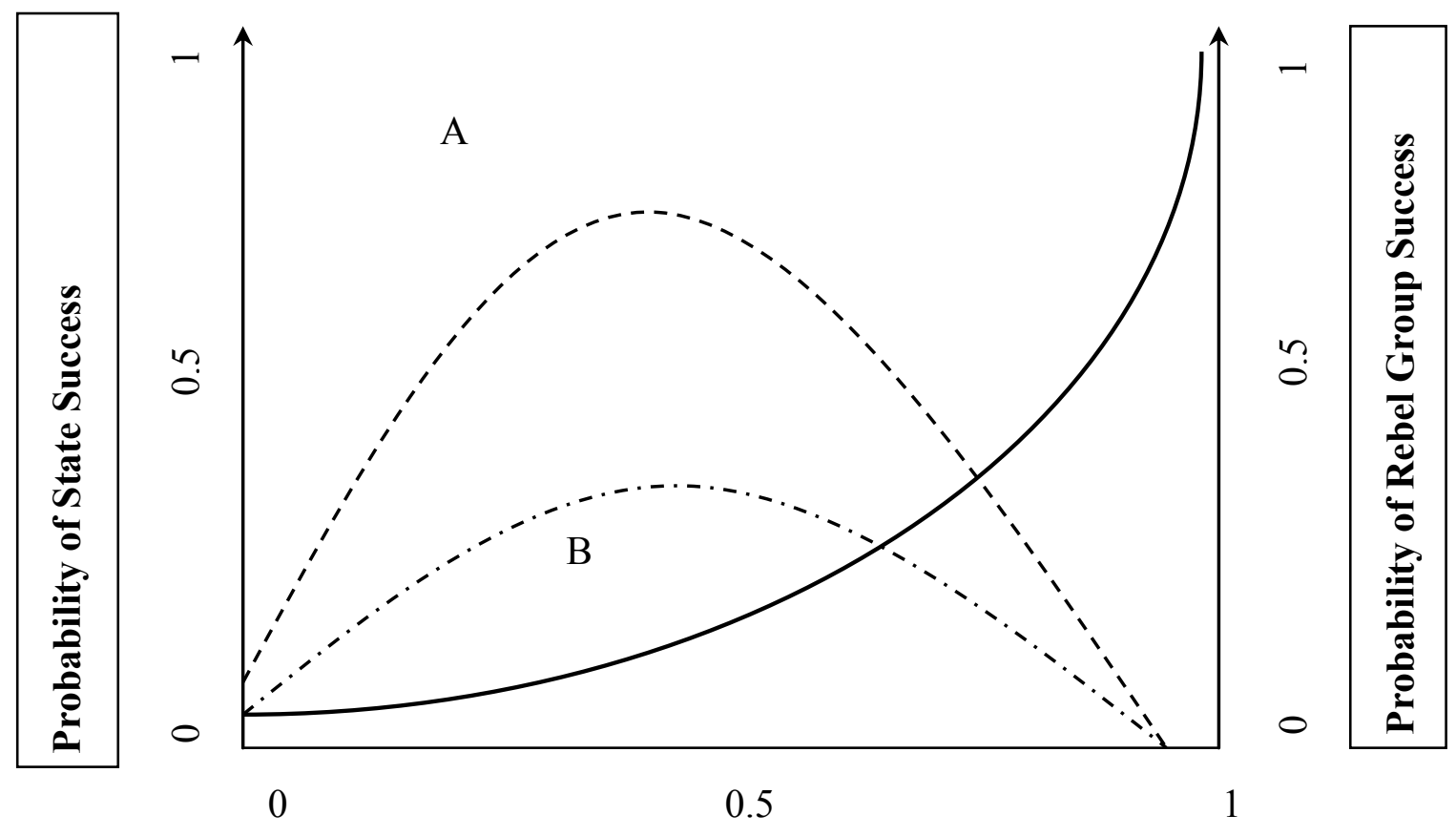

\section{Rebel Group Capacity Relative to the State}

Figure 5.7 depicts two state success curves: curve A and curve B. Curve A depicts a mobilization context wherein various conditions align to require that an insurgent group adopt some combination of a significant degree of organizational centralization and a large-scale administrative presence in order to mobilize higher levels of popular support over time. ${ }^{380}$ Since the insurgent group is compelled by the context of its mobilization efforts to become fairly centralized and to develop a large-scale administrative presence, the state stands a fairly good chance of beating the insurgency. Curve B, in contrast, depicts a state's success curve under some set of conditions that are more favourable to an

\footnotetext{
${ }^{380}$ For a similar idea that terrorist groups structure themselves in response to internal and external factors, see Joshua Kilberg, "A Basic Model Explaining Terrorist Group Organizational Structure," Studies in Conflict and Terrorism, Vol. 35, no. 11 (2012), 810-830.
} 
insurgency's efforts at mobilizing popular support. Here, the rebel group's more favourable mobilization context entails that it can abjure high degrees of organizational centralization and an expansion of its administrative presence to some extent, while still mobilizing a large amount of popular support. As a result, the state should find that the insurgency is harder to target (less vulnerable) and more resilient to being attacked by military means (more organizationally resilient) than would otherwise be the case. Put another way, the state should find it harder to defeat the insurgency through the application of military force, which means the rebel group is more likely to win the conflict overall, particularly if it can continue to mobilize higher levels of popular support over time. The fundamental point is that the context of a rebel group's mobilization (and all the conditions that form that context) can have a fairly radical effect on the odds that the state can defeat the insurgency. In very general terms, the presence or absence of any condition that reduces the need for an insurgency to adopt a centralized organizational structure and a large-scale administrative presence in order to mobilize higher levels of popular support contributes to the favourability of a rebel group's mobilization context.

\subsection{2- Condition 1: The Political Exclusivity of the State (A)}

The political exclusivity or openness of the regime affects, as noted in chapter 2 , the baseline preferences of the population for a political alternative such as the one that a rebel group invariably provides. ${ }^{381}$ Typically, the more politically exclusive the regime, the less likely it is that the bulk of the population is able satisfy its political, and likely economic, desires under the current regime. Such political exclusivity breeds an appetite

\footnotetext{
${ }^{381}$ See Jeff Goodwin, No Other Way Out: States and Revolutionary Movements, 1945-1991 (New York: Cambridge University Press, 2003).
} 
for a different political system, which an insurgent group readily offers. If a regime is more politically open and accessible to the population, or becomes more accessible during the course of a conflict, the population generally has less of a desire for a political alternative, meaning the rebel group's political program should be less attractive. When the population's preferences align in favour of a rebel group, as would occur in a more politically exclusive regime, an insurgency's mobilization of an average unit of popular support is cheaper than it would be under a more open or accessible political system.

In the context of Figure 5.7, curve A and curve B could represent an insurgent group's mobilization of popular support under a politically open and a politically exclusive regime, respectively. Under a fairly open regime, the population would have a lower preference for an alternative form of governance, as would be the case in the mobilization context surrounding curve A. As a result, the cost of an average unit of popular support for an insurgency would be higher than if the population held more favourable preferences towards the rebel group, as would plausibly be the case in mobilization context surrounding curve B. The less favourable the preferences of the population are towards an insurgency, the more matters of organizational efficiency and the scale of production are likely to matter in order for the group to increase its level of mobilized capacity to a level that will allow it to effectively challenge the state.

\subsection{3 - Condition 2: The State's Use of Indiscriminate Repression (B)}

As was noted in chapter 2, the state often faces an "identification problem" when facing an insurgency. ${ }^{382}$ This lack of information inhibits the state's ability to use discriminate

${ }^{382}$ Stathis N. Kalyvas, The Logic of Violence in Civil War (New York: Cambridge University Press, 2009), 8991. 
force that would selectively target insurgents amongst the mass of the population.

Instead, the state is often compelled to rely upon some form of indiscriminate repression in order to counter an insurgency. The problem with indiscriminate repression, in this context, is that it gives the population an incentive to join the rebellion in order to receive protection and avoid the worst of the state's violence. ${ }^{383}$ Often, in a context of large-scale repression, large swaths of the population join the insurgency, and provide the rebellion with other forms of active and passive support, without even demanding any compensation in return. ${ }^{384}$ Essentially, an insurgency that faces an indiscriminately repressive regime needs to provide less remunerative compensation and use less preference manipulation tactics in order to obtain a given level of support.

Since the amount of output that a group needs to produce in exchange for a given amount of support is less when the state is indiscriminately repressive, the incentive that a group faces towards either adopting a centralized organizational structure or developing a large-scale administrative presence is reduced. In the context of Figure 5.7, an insurgent group that is facing an indiscriminately repressive state could develop along, say, curve B. An insurgent group that is facing a restrained state that avoids using force against the population as much as possible could develop along, say, curve A. Repression can facilitate rebel mobilization.

\subsection{4 - Condition 3: Expansion of a Rebel Group's Administrative Presence by} Incorporating Pre-Existing Socio-Political Networks (C)

\footnotetext{
${ }^{383}$ Stathis N. Kalyvas and Matthew Adam Kocher, "How 'Free' is Free Riding in Civil Wars? Violence, Insurgency, and the Collective Action Problem," World Politics, Vol. 59, no. 2 (2007), 177-216.

${ }^{384}$ Elisabeth Jean Wood, Insurgent Collective Action and Civil War in El Salvador (New York: Cambridge University Press, 2003).
} 
As noted in chapter 3, a rebel group can expand its administrative presence via a combination of two processes: original organizational building and the incorporation of pre-existing socio-political networks. Original organization building requires that an insurgent group devote a considerable amount of capacity towards establishing and developing administrative organizations. This process of original organizational building is costly, as there are many fixed costs associated with setting up administrative structures for the first time. If, instead, an insurgent group is able to expand its administrative presence by effectively incorporating pre-existing socio-political structures into the insurgency's overarching organizational structure, then many of the fixed costs associated with establishing and developing functional administrative processes have already been paid by the initial socio-political actors. In essence, a rebel group that expands by building original administrative organizations typically has to pay higher average costs than a group that expands by incorporating pre-existing sociopolitical networks. The lower a group's average costs are, the faster an insurgency is able to grow and the more popular support it is able to mobilize, everything else being equal. In the context of Figure 5.7, an insurgent group that expands its administrative presence via the incorporation of pre-existing socio-political networks could develop a smaller scale administrative presence than a group that expands via original organization building, everything else being equal, and still mobilize a considerable amount of popular support. As a result, a state that is confronted by an insurgent group that expands its administrative presence via the incorporation of pre-existing networks would be along the state's success curve B. If the same state faced an insurgent group that expanded its 
administrative presence only through original organization building, then the regime would be along the state's success curve A.

\subsection{5 - Condition 4: External Support for an Insurgency (Illicit Crops, Lootable Resources, Diasporas, International Patrons, and International Markets)}

The material form of external support for an insurgent group includes armaments, money, other material resources and manpower. Popular support and external support are substitutes. External support reduces the amount of popular support that an insurgency requires in order to effectively challenge the regime. Since the amount of popular support that the group requires is less than would otherwise be the case, external support reduces the incentive that an insurgency faces towards centralizing organizationally and expanding its administrative presence. Plausibly, external support might also affect the quality of a group's weapons and armaments, which would increase their chances of winning. Here, I focus only on the former.

In Figure 5.7, a rebel group that receives external support could develop along curve B. Along this curve, the rebel group is able to mobilize capacity relative to the regime without needing to adopting too much organizational centralization and a largescale administrative presence. As a result, the rebel group's odds of winning improve quickly as it mobilizes more popular support, but the extent to which the group adopts the characteristics that favour the state does not grow that rapidly. In the end, the state should have a relatively hard time defeating an insurgency that has external support. This conclusion is consistent with various studies of the outcome of insurgent conflicts. ${ }^{385}$

\footnotetext{
385 Jason Lyall and Isaiah Wilson III, "Rage Against the Machines: Explaining Outcomes in Counterinsurgency Warfare," International Organization, Vol. 63, no. 1 (2009), 67-106; Jeffrey Record, Beating Goliath: Why Insurgencies Win (Washington: Potomac Books, Inc., 2009).
} 
In contrast, a rebel group that has to mobilize capacity without recourse to external support would need to rely more fully on the population. An insurgency without external support would be developing along, for example, curve A. In this sort of situation, the rebel group would need to become fairly centralized and expand its administrative presence to a significant degree in order to obtain enough capacity to be able to effectively challenge the state. As a result, the state's odds of defeating the rebel group increase a fair amount as the group reforms itself in an effort to mobilize more popular support.

\subsection{6 - Condition 5: A Weak State}

Research on civil war onset routinely shows that weak states favour the outbreak of rebellion. ${ }^{386}$ Likewise, rebel groups are more likely to win if the state is weak or is weakened during the course of the conflict due to some exogenous shock. ${ }^{387}$ At least a part of the relationship between state weakness and rebel group success clearly derives from the simple fact that a weaker opponent should be easier for an insurgency to beat, everything else being equal.

An additional element of why weak states are easier for an insurgency to defeat plausibly hinges upon the organizational and administrative advantages that come along with facing a weaker opponent. When engaged in warfare, the relative strength of the two sides matters. Yet, when an insurgent group is trying to grow larger, the absolute size that

\footnotetext{
386 James D. Fearon and David Laitin, "Ethnicity, Insurgency, and Civil War," The American Political Science Review, Vol. 97, no. 1 (2003), 75-90; Cullen S. Hendrix, "Head for the Hills? Rough Terrain, State Capacity, and Civil War Onset," Civil Wars, Vol. 13, no. 4 (2011), 345-370.

${ }^{387}$ See, for example, Theda Skocpol, States and Social Revolutions: A Comparative Analysis of France, Russia, and China (New York: Cambridge University Press, 2008); Jeff Goodwin, No Other Way Out: States and Revolutionary Movements, 1945-1991 (Cambridge: Cambridge University Press, 2003); Timothy P. Wickham-Crowley, Guerrillas \& Revolution in Latin America (Princeton: Princeton University Press, 1993).
} 
it is trying to reach determines what sort of organizational and administrative pressures the group faces. An insurgency can be relatively weak, say, 1,000 guerrillas, but be facing a weak state that controls, say, 1,500 soldiers. The fairly weak rebel group in this case controls 40 percent of the mobilized capacity within the country. The same insurgency might face a strong state that marshals, say, 40,000 soldiers, which leaves the insurgency with control over only 2.5 percent of the mobilized capacity in the country. In the first case, assuming a population of a reasonable size, mobilizing 1,000 people is not too difficult in the grand scheme of things. The rebel group might need to mobilize more popular support in order to win, but it can likely do so without significant reforms to its organizational and administrative structures. Without serendipitous intervention, the rebellion in the second case needs to grow way bigger in order to win. To even reach parity with the state in terms of mobilized capacity, the insurgency needs to mobilize 40,000 guerrillas. Growing to that large of an absolute size likely entails significant organizational reform towards higher levels of centralization and a large-scale expansion of the group's administrative presence, both of which make the group more likely to lose.

In the context of Figure 5.7, the rebel group that is faced off against a strong state would be along curve A, since this rebellion likely needs to adopt a high degree of organizational centralization and a large-scale administrative presence in order to reach its needed absolute size. The rebel group that is faced off against a relatively weak state would be along curve B, since this group can grow to be bigger than the state without needing to become that centralized or develop that expansive of an administrative presence. The absolute strength of the state determines how large, in absolute terms, the rebellion is going to need to grow. Since growth in absolute terms is what determines the 
sort of organizational and administrative structures the rebel group needs to adopt, insurgents that face weak states can remain decentralized and maintain a fairly small scale administrative presence and still grow large enough to win. At the same time, rebel groups that are faced off against strong states need to grow large in absolute terms in order to stand a chance of success, but this means they need to become, on average, more centralized and maintain a larger scale administrative presence.

\subsection{7 - Condition 6: A Large Population Base}

Studies on the onset of civil war have also found that large populations "favour insurgency" by allowing militarily weaker rebel groups to hide amongst the people. ${ }^{388}$ Certainly, it is probably easier to find an insurgent in a pool of ten people than in a pool of one hundred or one thousand, so the concealment benefits of a large population cannot be discounted. However, the mobilization and conflict outcome theory suggests an alternative mechanism through which a large population base can favour insurgency. An insurgency needs a certain amount of relative capacity in order to win. As it mobilizes more support, a rebel group's odds of defeating the state improve as well. For any given level of state strength, a larger population base should make mobilizing a larger absolute amount of popular support easier, in the same way that a larger market for a product makes securing profit more likely. This initiation suggests that, in countries that have larger populations, rebel groups should be able to mobilize higher levels of absolute support without needing to reform themselves organizationally or administratively in ways that favour the state.

\footnotetext{
${ }^{388}$ James D. Fearon and David Laitin, "Ethnicity, Insurgency, and Civil War," The American Political Science Review, Vol. 97, no. 1 (2003), 80.
} 
In the context of Figure 5.7, rebel groups that are trying to mobilize to challenge a regime in a sparely populated country would be along, say, Curve A. Here, to mobilize enough support would require an organizational structure that is centralized to maximize efficiency and a large-scale administrative presence to secure the best possible margins on its production of popular support-securing outputs. In contrast, an insurgent group that is mobilizing to challenge a regime in a heavily populated country would find a larger market for their popular support-securing outputs and should, therefore, be able to mobilize more support with less of a pressure to reform organizationally or administratively. Such a rebel group could mobilize relative capacity along, say, curve B.

\section{4 - Conclusions}

In this chapter, I presented a baseline framework for understanding why some rebel groups win and others lose. In testing the baseline framework, I imposed a condition of autarky upon the data because it is under this condition that the anticipated effects will be most pronounced and under this condition that the proxy for popular support that I used to test the framework is most accurate. Overall, the theory basically suggests that as an insurgent group mobilizes more popular support relative to the regime, its odds of winning go up. At the same time, and quite paradoxically, the state's odds of winning also improve, in as much as the rebellion's mobilization of popular support requires that it adopt a centralized organizational structure and an expanded administrative presence. Both rebel and state success can improve because the odds that the conflict will simply continue into another period goes down.

I derived three hypotheses from this theory. First, the state should almost always win under generally autarkic conditions. Second, the relationship between an 
insurgency's mobilization of popular support under autarkic conditions and state success should be positive, just as long as the insurgency controls less than 50 percent of the total mobilized capacity within the conflict. Finally, the biggest rebel groups in absolute terms (as in they have the most insurgents) should also be predominantly centralized with a large-scale administrative presence. I found tentative support for each hypothesis.

Lastly, I outlined several conditions that combine together to compose what I have called a rebel group's mobilization context. Furthermore, I outlined how these factors affect the ease with which an insurgency can mobilize popular support and therefore the rebel group's odds of winning the conflict. 


\section{Chapter 6: Evidence on the Mechanisms from Four Types of Insurgencies}

In the previous chapter, I tested the general plausibility of the mobilization and conflict outcome theory. In this chapter, I develop a typology of insurgent groups based upon each group's exhibited level of organizational centralization (either high or low) and the scale of each group's administrative presence (again, either high or low). Four types of insurgencies emerge from this classification: diffuse, vanguard, fragmented, and bureaucratic. The typology illustrates that different types of rebel groups have different general strengths and weaknesses. Moreover, each type of insurgency likely has a unique propensity towards success or failure, with groups with low administrative presence and low organizational centralization being both hard to defeat and unlikely to win, while groups with a high administrative presence and a high degree of organizational centralization being the most likely to win but also the easiest to defeat, everything else being equal. The typology of rebel groups also provides specific predictions about how a conflict involving each type of group should generally unfold, as well as an explicit depiction of what mechanisms should be involved. In this chapter, I test the predictions associated with each type of rebel group against evidence from an insurgency that exemplifies each type. The results are consistent with the predictions of the mobilization and conflict outcome theory, which suggests that the theory has a large degree of internal validity.

\section{1 - A Typology of Rebel Groups: Administrative Presence and Organizational Centralization}

In this section, I develop a typology of insurgent groups. The typology categorizes all insurgent organizations according to two voluntarily selected features of the group: the 
scale of the group's administrative presence and its organizational centralization. After presenting the typology, I discuss the dominant characteristics of each type of insurgency. The typological theory also specifies some predictions about how a conflict involving each type of insurgency should generally unfold. I test these predictions against the historical evidence from an insurgency of each type. The typological theory is well supported by the evidence from these cases.

\section{Table 6.1. A Typology of Rebel Organizations}

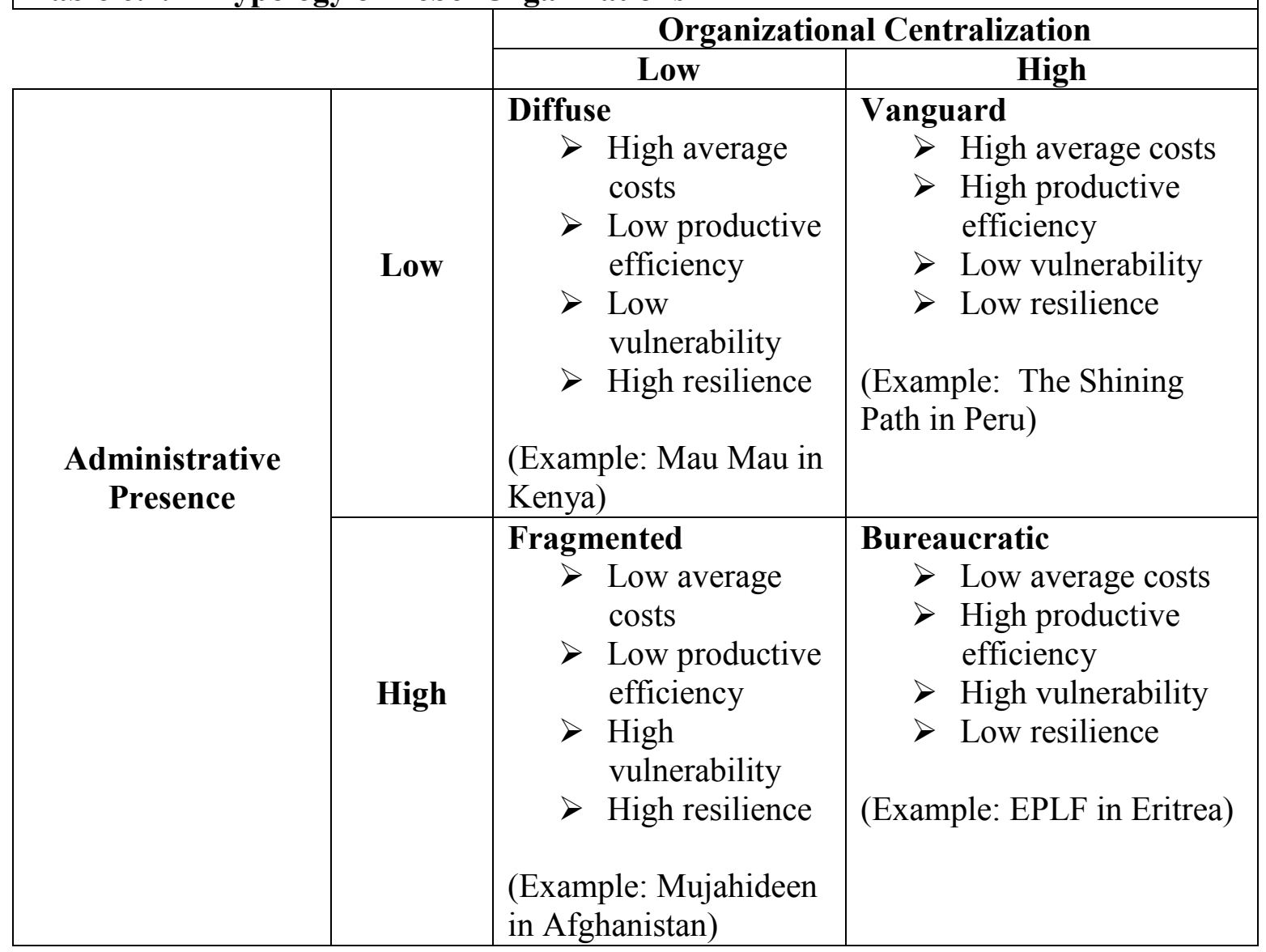


A functional typology must classify phenomenon in a way that is both exhaustive and mutually exclusive. ${ }^{389}$ What this means, in this case, is that the typology needs to be able to, first, classify all insurgent groups (exhaustive), and, second, place each insurgent group in one and only one cell of the typology at any point and time (mutually exclusive). A typology can be developed using as many conceptual dimensions as are necessary to adequately describe the forms of the phenomenon at hand. In developing a typology, there is a core trade-off between increased explanatory power and increased complexity. More explanatory power is generally obtained if the number of conceptual dimensions expands, but this also increases the complexity of the typology exponentially. The basic formula for calculating the number of cells in a typological formulation involving only dichotomous variables is $2^{\mathrm{x}}$, so a typology with two dimensions leads to four possible types, a typology with 3 dimensions leads to 8 types, and a typology of 4 dimensions leads to 16 types, and so forth. ${ }^{390}$ A good typology maximizes the similarity of units within each type and maximizes the differences between types. ${ }^{391}$ The main aim of typological theory, as I develop it here, is to predict how segments of a broader phenomenon (insurgency, in this case) unfold differently depending upon their type.

There are already several works that classify rebel or terrorist groups according to their level of organizational centralization. Joshua Kilberg, for example, classifies insurgent and terrorist groups according to each organization's level of centralization. In

\footnotetext{
${ }^{389}$ The discussion of typologies is drawn from Kenneth D. Bailey, Typologies and Taxonomies: An Introduction to Classification Techniques (London: Sage Publications, 1994), 3-5; see, also, Alexander L. George and Andrew Bennett, Case Studies and Theory Development in the Social Science (Cambridge: MIT Press, 2005), 233-262.

${ }^{390}$ Kenneth D. Bailey, Typologies and Taxonomies: An Introduction to Classification Techniques (London: Sage Publications, 1994), 4-5.

${ }^{391}$ Alexander L. George and Andrew Bennett, Case Studies and Theory Development in the Social Science (Cambridge: MIT Press, 2005), 237.
} 
his classification, groups range, in descending order of centralization, from bureaucratic, to hub-and-spoke, to all-channel, to market structure. ${ }^{392}$ In a similar fashion, Patrick Johnston develops a classification of rebel group organizational structure ranging from "U-form" to "M-form" insurgent groups - or from more centralized to more decentralized groups ${ }^{393}$ Francisco Gutierrez Sanin and Antonio Giustozzi develop a typology of rebel organizations that ranges from diffuse and decentralized "networks" to hierarchical and centralized "armies." ${ }^{394}$ Finally, in an extensive book on insurgent group organizational structure and group military performance, Abdulkader H. Sinno proposes a classification of organizational forms that ranges from centralization, to decentralization, to clientage, to multiplicity, and, finally, to organizational fragmentation. ${ }^{395}$

Each of these typologies classifies insurgencies according to only a single conceptual dimension, namely, the extent of each insurgent group's organizational centralization. My typology of insurgent movements classifies each group according to both its administrative presence and its organizational centralization. In order to manage the number of types included in the typology, I treat both conceptual variables as being dichotomous, with every insurgent group having either a high or a low value on each. ${ }^{396}$ As Table 6.1 outlines, a typology based upon a rebel group's organizational centralization

\footnotetext{
392 Joshua Kilberg, "A Basic Model Explaining Terrorist Group Organizational Structure," Studies in Conflict and Terrorism, Vol. 35, no. 11 (2012), 810-830. For further discussion, see Joshua Kilberg, Organizing for Destruction: How Organizational Structure Affects Terrorist Group Behaviour (Ottawa, Carleton University: Unpublished Ph.D. Dissertation).

393 Patrick Johnston, "The Geography of Insurgent Organization and Its Consequences for Civil Wars: Evidence from Liberia and Sierra Leone," Security Studies, Vol. 17, no.1 (2008), 107-137.

${ }^{394}$ Francisco Gutierrez Sanin and Antonio Giustozzi, "Networks and Armies: Structuring Rebellion in Colombia and Afghanistan," Studies in Conflict and Terrorism, Vol. 33, no. 9, (2010), 836-853.

${ }^{395}$ Some of Sinno's classifications do not directly vary along the centralization-decentralization scale, but all do speak to the internal organizational structure of the group in question. See, Abdulkader H. Sinno, Organizations at War: In Afghanistan and Beyond (Ithaca: Cornell University Press, 2008).

${ }^{396}$ On typologies as a form of theory, see D. Harold Doty and William H. Glick, "Typologies as a Unique Form of Theory Building: Toward Improved Understanding and Modeling," Academy of Management Review, Vol. 19, no. 2, (1994), 230-251.
} 
and the scale of its administrative presence leads to a typology including four types of insurgencies: diffuse, fragmented, vanguard, and bureaucratic. Each type of insurgency has different exhibited behaviours that are produced by the group's administrative presence and organizational centralization. These characteristics are listed below the name of each type of insurgency in each respective cell. Each type of insurgency, moreover, has a different propensity towards success and failure, again due to their divergent administrative and organizational components, which will be discussed in more detail below.

Table 6.2 outlines the four discrete criteria that I use to operationalize each concept. Below each operational measure, I list the precise question that I asked in the coding of each insurgency and an example of some of the more ambiguous terms. A group's organizational centralization is operationalized through measurement of the four organizational elements outlined in Chapter 3: hierarchical decision-making, coordination mechanism, organizational specialization, and control and monitoring mechanisms. A group's administrative presence is operationalized through measurement of the scope of the group's political associations, the size of its remunerative compensation infrastructure, the capacity of its preference manipulation system, and the geographical scope of the group's administrative penetration, broadly defined. 


\section{Table 6.2. Operational Measures of Rebel Group Organizational Centralization and Administrative Presence}

\begin{tabular}{|l|}
\hline Organizational Centralization \\
\hline 1) Specialization of the group's subunits \\
-Are subunits self-sufficient or do \\
they depend upon other elements in \\
the broader organization to a \\
significant degree? (For example, \\
compartmentalized cells versus \\
groups with distinct tasks)
\end{tabular}

2) Hierarchy in the group's decisionmaking

-Are strategic and political decisions made by a well-defined leadership? (For example, a single or small collective of individuals who direct the group's operations)

\section{3) Centrally planned and coordinated} efforts

-Are there well-defined and effective coordinating and planning element in the insurgency's organization? (For example, specialized military and administrative organs that allocate resources)

4) Scope of the group's monitoring and control mechanisms

Is the organization able to monitor and control its membership? (For example, organizational reporting and verification systems and clear punishment mechanisms)

\section{Administrative Presence}

1) Scope of the group's political associations

- Does the group have a significant and well-developed political association in areas it aims to control? (For example, parallel hierarchies)

2) Size of the group's remunerative compensation infrastructure

- How well-developed are the facilities used to produce popular support-securing outputs in contested areas? (For example, hospitals and schools)

3) Capacity of the group's preference manipulation system

- How well-developed are the facilities used to produce popular support-securing outputs in contested areas? (For example, guerrilla units tasked to manipulate the population through coercion or propaganda)

4) Geographical scope of the group's administrative structures

- How much of the contested area is infiltrated by insurgent administrative organs? (For example, the number of villages that have a concrete rebel group presence) 
To determine whether an insurgency has a high or a low value on each of these conceptual measures, I employ a variant set membership to formally operationalize each concept. ${ }^{397}$ In this process, I assigned each insurgent group a score, ranging from 0 to 1 , on each of the four discrete operational measures of each concept. A score of 0 indicates that the component was totally absent. A score of 1 indicates that the component was present in an extremely large degree. Maximal or minimal scores of this sort were not assigned in any cases considered here. A value of 0.5 means that the component is present to some qualitatively significant extent. On the basis of this coding, I aggregated the scores and divided the summed total by the number of operational components. This process results in a final average score for each concept, still ranging from 0 to 1 , that indicates the extent of a rebel group's centralization and the scale of its administrative presence. Values at or above 0.5 fall into the high end of each concept, while values below 0.5 are coded as being low on that concept.

I deliberately developed the coding criteria for the scale of a rebel group's administrative presence to emphasize the depth of a group's presence over its breath. As is apparent in Table 7.2, the first three criteria deal with the density or thickness of the insurgency's administrative presence. These criteria show how present the various components are in a given area for a given period of time. The fourth criterion captures the actual geographical scope of the insurgency's administrative presence. Given the coding procedure employed in this study, rebel groups that have a large geographical reach but limited administrative depth are unlikely to be coded as having a high overall

\footnotetext{
${ }^{397}$ On set theory, see Charles Ragin, The Comparative Method: Moving Beyond Qualitative and Quantitative Strategies (Berkeley: University of California Press, 1987); Charles Ragin, Fuzzy-Set Social Science (Chicago: University of Chicago Press, 2000). On the basics of using set-theoretic methods, see Carsten Q. Schneider and Claudius Wagemann, Set-Theoretic Methods for the Social Sciences: A Guide to Qualitative Comparative Analysis (New York: Cambridge University Press, 2012).
} 
administrative presence. In contrast, rebel groups with a well-developed administrative presence in fewer areas stand a better chance of being coded as having a high administrative presence.

This coding rule, while seemingly biased toward geographically concentrated groups, is better than a more equal weighting. Since it emphasizes density over breadth, the measurement rule can actually code both nationalist and secessionist insurgencies without requiring any ex ante knowledge of the goals and territorial aims of the various groups. Nationalist insurgencies usually aim to control as much territory as possible so as to capture the state. Secessionist insurgencies usually aim to control only historic territory and aim to carve this chunk of territory off from the main whole. ${ }^{398}$ If administrative breadth were to be given equal weight to administrative depth in the coding rules, few secessionist insurgencies would ever have a high score on the administrative variable. In other words, they would never be of either the bureaucratic or fragmented types, unless an additional rule was put into place that stipulated that breadth should only be measured relative to the rebel group's desired scope of territorial control. By placing a greater emphasis on administrative depth, the current coding rules give a more reasonable estimate of the true type of both nationalist and secessionist insurgencies, although the coding rules might somewhat under represent the 'real' type of nationalist insurgencies.

There are three limitations to this coding procedure that need to be acknowledged. First, the results of the coding process are equifinal, so two groups can have a score on their organizational dimension of, say, 0.55 , but reach this level through very different routes. One rebel group, for example, could have a strong hierarchy with well-defined

\footnotetext{
${ }^{398}$ On secessionist conflicts, see Monica Duffy Toft, The Geography of Ethnic Violence: Identity, Interests, and the Indivisibility of Territory (Princeton: Princeton University Press, 2005).
} 
coordination mechanisms, but lack in subunit specialization and have only moderate control and monitoring mechanisms. The other group could be the exact opposite, with weak leadership and coordination mechanisms, but a lot of subunit specialization and very robust control and monitoring mechanisms. If the numbers fell correctly, both groups could score 0.55 on their measure of organizational centralization and be coded as one of the two types of centralized insurgent groups. However, these two groups would clearly have somewhat different strengths and weaknesses that could presumably affect the ebb and flow of the conflict. Two things can be said about this issue. First, the aim of the typology is to compare groups with markedly divergent scores on each concept (high versus low), so comparisons between groups within each category are less important at this stage. Second, it is likely that, in empirical terms, the various operational elements of each concept are mutually reinforcing, so the actual level of similarity within each category likely remains greater than the differences that are theoretically possible.

A second, related problem is that the coding procedure weights each of the four operational elements equally. For example, both a well-defined leadership and high subunit specialization each compose 25 percent of the group's overall organizational centralization score. This weighting assumes, first, that each operational component is equally as important to a group's aggregate level of centralization as every other measure. Secondly, the weighting is fixed at 25 percent, which assumes that the marginal contribution of each component to a group's overall level of organizational centralization (or administrative presence) is constant. Likely, both concerns are valid in some measure, but attempting to vary the weight of each component across time and context is likely to 
reduce the reliability of the coding and increase the subjectivity of the results. The fixed weighting makes for a more replicable coding procedure.

The third potential problem is that the assigned scores on each operational measure are necessarily pinpointed relative to an incomplete knowledge of the general distribution of values for all insurgent groups. For example, I might code an insurgency as having a very high level of, say, 0.8 on all four of the components of organizational centralization. This coding invariably relies upon some implicit understanding of what a 'very high level' on each of the components is relative to other insurgent groups. Without a definitive understanding of where each insurgent group falls along the distribution of all groups, the value assigned to any particular group is invariably set relative to some theoretical ideal (an ideal that is, of course, informed by an empirical foundation that is as broad as possible). ${ }^{399}$ The problem is that I could come across another subset of the entire universe of insurgent groups that all have far higher demonstrable levels on each of the operational components of organizational centralization. I would then need to recalibrate my initial measure downwards to accommodate the newly discovered subsample. In this sense, the assigned measurements remain somewhat tentative. Of course, every effort has been made to develop both a strong theoretical and empirical understanding of the general distribution of insurgencies before assigning the measures to the four cases considered here.

Finally, a few thoughts on case selection are in order. My core aim in selecting the cases for the analysis in this chapter was to avoid picking any instances of insurgency according to the values on the dependent variables of interest, namely, the expected

\footnotetext{
${ }^{399}$ This is similar to the principle of calibration in set-theory. See Carsten Q. Schneider and Claudius Wagemann, Set-Theoretic Methods for the Social Sciences: A Guide to Qualitative Comparative Analysis (New York: Cambridge University Press, 2012), 32.
} 
outcomes of the scope and rate of mobilization and the rebel group's resiliency and vulnerability. Instead, I aimed to select cases that had clear values on the two independent variables of interest, that is, group centralization and the scale of the group's administrative presence. ${ }^{400}$ The outcomes, then, were allowed to vary so long as the cases fit into the cells of the typology using the coding criteria outlined above. While I was obviously not oblivious to the outcome of the cases when I selected them for more detailed research, my main aim was to pick cases that had the right causes and to let the effects fall as they may. As is evident below, the EPLF case study does not conform perfectly with the theory, which shows both some of the limits of the theory and the reliability of the case selection process.

Below, I discuss the empirical characteristics that each type of insurgency possesses as a result of the various combinations of administrative presence and organizational centralization. I also outline how the typological theory predicts each type of insurgency should generally unfold. I then provide an historical example of each type of insurgency and test the accuracy of the predictions that I derive from the theory against the case history. When discussing the characteristics of each type of insurgency in general terms, I assume a more or less neutral mobilization context, which is to say that the population is not favourably disposed either for or against the insurgency. In the empirical examples, I provide a preliminary assessment of the mobilization context that each respective insurgency faced in order to provide some background about the environment within which each insurgency emerged.

\footnotetext{
${ }^{400}$ On the perils of selecting cases on the dependent variable, see Gary King, Robert O. Keohane, and Sidney Verba, Designing Social Inquiry: Scientific Inference in Qualitative Research (Princeton: Princeton University Press, 1994), 129-132.
} 


\section{2 - Diffuse Insurgencies}

Diffuse insurgencies have a low administrative presence and a low level of organizational centralization. Groups of this type manifest two main tendencies simultaneously. Diffuse insurgencies are, first of all, unlikely to mobilize a significant amount of popular support, due to their lack of a large administrative presence and their minimal degree of organizational centralization. At the same time, controlling for the strength of each respective rebel group, diffuse insurgencies are likely hard to defeat with military means since they are not very vulnerable to targeting, due to their low administrative presence, and are likely fairly resilient to state military pressure, due to their decentralized organizational structure. Of the four types of insurgencies, the combination of characteristics that is indicative of this type of group means that, at a given point and time, diffuse insurgencies are unlikely to defeat the state (too weak to do so) and are fairly hard for the state to actually defeat (hard to hit and hard to hit effectively), everything else being equal. 
Figure 6.1. Diffuse Insurgencies

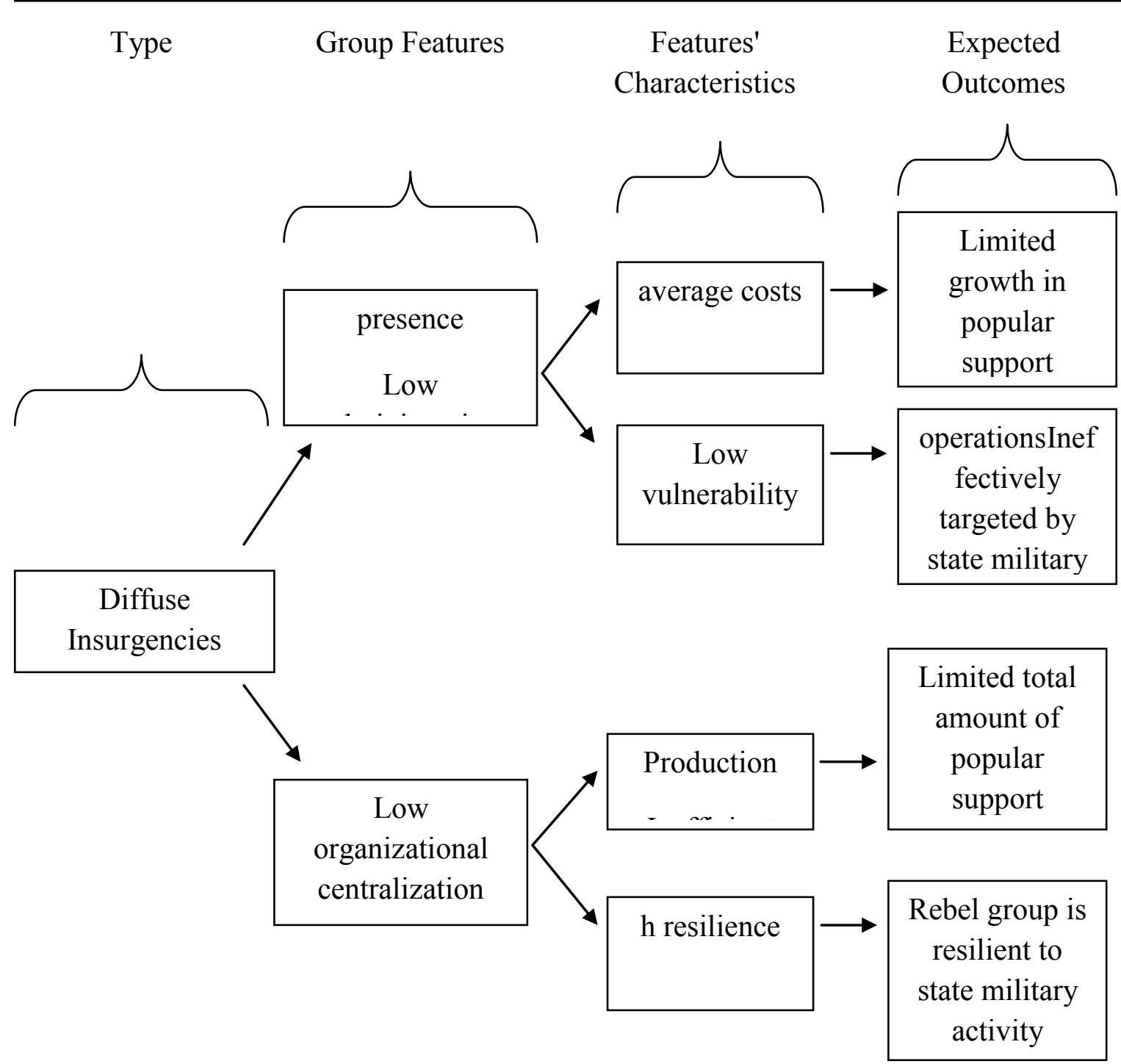

The causal relationships between the features of a diffuse insurgency (low administrative presence and low organizational centralization) and its ability to both mobilize popular support and stand against the regime is depicted in Figure 6.1. The figure outlines the general expectations of what ought to occur during a conflict if an insurgency is of the diffuse type. The predicted outcomes that should occur during a conflict involving a diffuse insurgency are listed as the final outcomes of the sequence at the far right-hand side of the figure under 'Expected Outcomes.' In short, diffuse 
insurgencies should have a limited rate of mobilization of popular support, be limited in the overall amount of support they can mobilize, be hard for the regime to target militarily, and resilient if they are targeted.

\subsection{1 - The Mau Mau Insurgency, 1952-1956}

A good example of a diffuse insurgency is the Mau Mau insurrection in Kenya, which broke out in 1952 and continued until military operations largely ceased in 1956. From the insurgency's perspective, the Mau Mau faced a fairly favourable mobilization context, due to the exclusive nature of the colonial state and the pronounced concentration of political and economic power in the hands of the European settlers. ${ }^{401}$ The favourable context of the insurgency made popular support a lot cheaper for the insurgency, which somewhat reduced the incentive for the insurgency to adopt a highly centralized organizational structure and an expanded administrative presence. Efforts were still made at both expanding the Mau Mau's administrative presence and at centralizing its organization, but these attempts largely failed to produce any significant results. ${ }^{402}$ In the end, the Mau Mau failed to mobilize a significant amount of popular support, posed little real challenge to the colonial regime as a result, and were eventually defeated by the British counterinsurgents.

The Mau Mau rebellion's administrative presence was limited in breadth, certainly, and also fairly limited in depth. The insurrection was confined geographically to the Aberdare Range, the Kikuyu reserves, the area around Mount Kenya in Central

\footnotetext{
${ }^{401}$ Wunyavari O. Maloba, Mau Mau and Kenya: An Analysis of a Peasant Revolt (Indianapolis: Indiana University Press, 1993).

${ }^{402}$ See, for example, Donald L. Barnett and Karari Njama, Mau Mau from Within: Autobiography and Analysis of Kenya's Peasant Revolt (London: MacGibbon \& Kee, 1966), 157-168.
} 
Province, and, to a limited extent, to the capital city of Nairobi. The Mau Mau were unable to develop any significant administrative breadth in other areas of the country. ${ }^{403}$ Rebel recruitment of popular support was also largely confined to the Kikuyu tribal group, although it was able find some purchase among the Embu and the Meru. Within the Kikuyu tribal grouping, the Mau Mau had fairly widespread adherence, and, by 1952, "somewhere between 75 per cent and 90 per cent of the Kikuyu population had taken the Oath of Unity," which was the insurgency's main method of securing a very basic degree of popular support. ${ }^{404}$

The Mau Mau had several political associations governing the people who fled into the forests of Central Province, although the extent of these political groupings remained limited and autonomous from one another. ${ }^{405}$ The Mau Mau did not undertake any significant provision of remunerative compensation, providing little-to-no services and few material goods to the people. The Mau Mau did use more extensive preference manipulation tactics, as they mainly attempted to secure popular support through a combination of physical coercion and the various Oaths of Unity that were intended to 'magically' bond the population to the insurgency (a process that would, today, be known as propaganda). Overall, the administrative presence of the Mau Mau insurgency was

\footnotetext{
${ }^{403}$ Wunyavari O. Maloba, Mau Mau and Kenya: An Analysis of a Peasant Revolt (Indianapolis: Indiana University Press, 1993), 65.

${ }^{404}$ Donald L. Barnett and Karari Njama, Mau Mau from Within: Autobiography and Analysis of Kenya's Peasant Revolt (London: MacGibbon \& Kee, 1966), 66.

${ }^{405}$ The Mwathe Meeting was one of the main efforts at building some sort of overarching organizational system that could coordinate and oversee the four autonomous areas of Aberdare forest, namely, Nyeri, Murang'a, Nderagwa, and North Kinangop. These efforts were not overly successful. See, Donald L. Barnett and Karari Njama, Mau Mau from Within: Autobiography and Analysis of Kenya's Peasant Revolt (London: MacGibbon \& Kee, 1966), 225-268.
} 
very low, which made the production of large quantities of popular support-securing outputs prohibitively costly for the insurgency in most cases. ${ }^{406}$

The Mau Mau's low administrative presence meant that the insurgency remained highly mobile, as it lacked any fixed assets and organization and held little pressing responsibility for the population. The Mau Mau's organization and membership also blended in with the surrounding population, which reduced the contrast between the rank and file of the insurgency and the people. As a result of these factors, the insurgency was very difficult to target militarily. ${ }^{407}$ In response, the British counterinsurgency took to indiscriminately targeting members of the Embu, Meru, and, in particular, Kikuyu tribal groups. ${ }^{408}$ It also resorted to large-scale detention and resettlement in order to sever the links between the population and the insurgency. Overall, the low administrative presence of the Mau Mau insurgency generally inhibited the ability of the British counterinsurgency to target the insurrection with military means, although there were, of course, some engagements. ${ }^{409}$

\footnotetext{
${ }^{406}$ On the basis of this survey of the Mau Mau's administrative presence, I gave each of the four operational components of a rebel group's administrative presence the following values: political associations (0.4), remunerative compensation infrastructure (0.2), preference manipulation capacity (0.5), geographical scope (0.3). Employing the coding procedure outlined above, the summation of these values and the division of that total by the number of operational components results in an aggregate score of 0.325 for the Mau Mau's administrative presence. In other words, the Mau Mau had a very low administrative presence, as befits a diffuse insurgency.

${ }^{407}$ For a detailed account of the British counterinsurgency against the Mau Mau, see Hew Bennett, Fighting the Mau Mau: The British Army and Counter-Insurgency in the Kenya Emergency (New York: Cambridge University Press, 2013).

${ }^{408}$ Wunyavari O. Maloba, Mau Mau and Kenya: An Analysis of a Peasant Revolt (Indianapolis: Indiana University Press, 1993), 82-86.

${ }^{409}$ For a detailed semi-autobiographical account of the Mau Mau Emergency, see Donald L. Barnett and Karari Njama, Mau Mau from Within: Autobiography and Analysis of Kenya's Peasant Revolt (London: MacGibbon \& Kee, 1966).
} 
As a diffuse insurgency, the Mau Mau also lacked much in the way of organizational centralization. ${ }^{410}$ Shortly after the British had declared a state of emergency, state forces arrested many prominent African leaders associated with the Kikuyu Central Association (KCA) and the Kenya African Union (KAU). For the Mau Mau, the removal of the leadership of these organizations "practically wiped out its key leadership committees and severed the coordinating linkages between central institutions and the rank and file [of the insurgency] in the reserves." ${ }^{411}$ While the actual linkages between the formal political associations and the emergent Mau Mau revolt were never particularly strong, the removal of the prominent African leadership eroded both the actual and the potential level of hierarchical organization that the movement could obtain.

The lack of organizational centralization resulted in inefficient production of popular support-securing outputs and caused the group to suffer from higher-thannecessary production costs, including high decision-making, coordination, opportunity, and agency costs. Agency costs, or the costs that an insurgency must absorb if it cannot effectively control and monitor its membership, were particularly pronounced. As Wunyavari O. Maloba puts it, "As the revolt dragged on, parasitic and criminal elements in Central Province emerged and took advantage of Mau Mau's diffuse and incoherent organizational structure" to loot and abuse the population, which reduced the amount of popular support that the group received. ${ }^{412}$ Other costs due to organizational

\footnotetext{
${ }^{410}$ Wunyavari O. Maloba, Mau Mau and Kenya: An Analysis of a Peasant Revolt (Indianapolis: Indiana University Press, 1993), 77.

${ }^{411}$ Kenneth W. Grundy, Guerrilla Struggle in Africa: An Analysis and Preview (New York: Grossman Publishers, 1971), 80; Donald L. Barnett and Karari Njama, Mau Mau from Within: Autobiography and Analysis of Kenya's Peasant Revolt (London: MacGibbon \& Kee, 1966), 70.

${ }^{412}$ Ibid., 123. Agency costs of this sort are also noted in Donald L. Barnett and Karari Njama, Mau Mau from Within: Autobiography and Analysis of Kenya's Peasant Revolt (London: MacGibbon \& Kee, 1966), 221.
} 
decentralization were also present. The "organization," as the former Mau Mau Karari Njama recalls it, "was loose in the sense that there was no clear-cut division of labour, hierarchy of roles or differential privileges." ${ }^{413}$ This lack of organizational specialization increased the group's opportunity costs, while the lack of hierarchy compounded the costs of decision-making. Moreover, even after some efforts at centralizing the organizational structure of the insurgency had been made, the Mau Mau ruling "Council lacked what might be termed an independent enforcement arm" to sanction task-shirking or rent seeking behaviour. ${ }^{414}$ Additionally, "no formal relations existed [between the various subunits of the organization] whereby policies, strategy, and tactics could be unified or coordinated." ${ }^{415}$ In short, the Mau Mau's lack of organizational centralization generated high agency, coordination, opportunity and decision-making costs, which undermined its ability to produce a significant amount of popular support-securing outputs. As a result, while many recruits were pushed into the insurgency through the state's use of indiscriminate repression, the overall size and growth of the insurgency was inherently limited. ${ }^{416}$ At its peak, the Mau Mau insurgency mobilized only around 15,000 guerrillas, many of whom fled to join the insurgency in response to the state's use of indiscriminate force rather than in response to any active behaviour on the part of the rebels. ${ }^{417}$

While the organizational decentralization of the Mau Mau insurgency inhibited the group's ability to secure popular support in some measure by reducing the efficiency

\footnotetext{
413 Donald L. Barnett and Karari Njama, Mau Mau from Within: Autobiography and Analysis of Kenya's Peasant Revolt (London: MacGibbon \& Kee, 1966), 153.

414 Ibid., 169.

415 Ibid., 171.

${ }^{416}$ On the basis of this discussion, I coded the Mau Mau insurgency as having the following dimensions on the four organizational components: Specialization (0.2), Coordination mechanisms (0.3), control and monitoring mechanism (0.2), hierarchy (0.4). Following the coding procedures outlined above, this gives the Mau Mau an organizational centralization score of 0.275 , well below the 0.5 cut off.

${ }^{417}$ Donald L. Barnett and Karari Njama, Mau Mau From Within: Autobiography and Analysis of Kenya's Peasant Revolt (New York: Modern Readers Paperback, 1966), 197.
} 
of its production of popular support-securing outputs, the insurgency's loose

organizational structure also increased the group's resiliency in the face of state military pressure. For instance, according to one characterisation, "The lack of obvious leaders made it difficult for the authorities to dismantle the organization without large-scale detention." ${ }^{418}$ The British counterinsurgency essentially needed to use more military force in order to contend with the Mau Mau's lack of organizational centralization than would otherwise have been the case had the group been more centralized with more mutually reliant organizational subunits. ${ }^{419}$ The insurgency was, in other words, fairly resilient in the face of state military pressure, although its ultimate ability to resist state pressure was undermined by its sheer weakness relative to the regime.

The case study of the Mau Mau rebellion as an example of a diffuse insurgency conforms with the predicted expectations of the theory. All four predicted outcomes limited growth in popular support, ineffectually targeted state military operations, limited total amount of popular support, and high rebel group resiliency to state military activity - were apparent in the Mau Mau insurrection.

In sum, diffuse insurgencies have both a low administrative presence and a low level of organizational centralization. As a result of this combination of traits, diffuse insurgent groups are unlikely to grow very quickly and are likely to be fairly limited in their total size, as they are unable to mobilize significant amounts of popular support. In turn, the lack of popular support suggests that, everything else being equal, diffuse insurgencies are not likely to present a serious challenge to the state that they are

\footnotetext{
${ }^{418}$ Ian F.W. Beckett, Modern Insurgencies and Counter-Insurgencies (New York: Routledge, 2001), 123.

${ }^{419}$ For a recent account of the British counterinsurgency in Kenya that emphasizes how the British were never able to cleanly identify the insurgency and relied upon costly uses of force, see Huw Bennett, Fighting the Mau Mau: The British Counter-Insurgency in the Kenya Emergency (Cambridge: Cambridge University Press, 2013).
} 
confronting. Put otherwise, it should be rare for a diffuse insurgency to be able to defeat the regime. At the same time, diffuse insurgencies are both hard to target militarily (not very vulnerable) and organizationally resilient to being targeted, everything else being equal.

\section{3 - Vanguard Insurgencies}

Vanguard insurgencies have a low administrative presence and a high level of organizational centralization. The low administrative presence of a vanguard insurgency limits the amount of popular support-securing outputs that the group can produce, but also limits the group's vulnerability to being targeted by state forces. The high organizational centralization of this type of insurgency results in fairly efficient production of popular support-securing outputs, but a lack resilience to being targeted by counterinsurgent military means. 


\section{Figure 6.2. Vanguard Insurgencies}

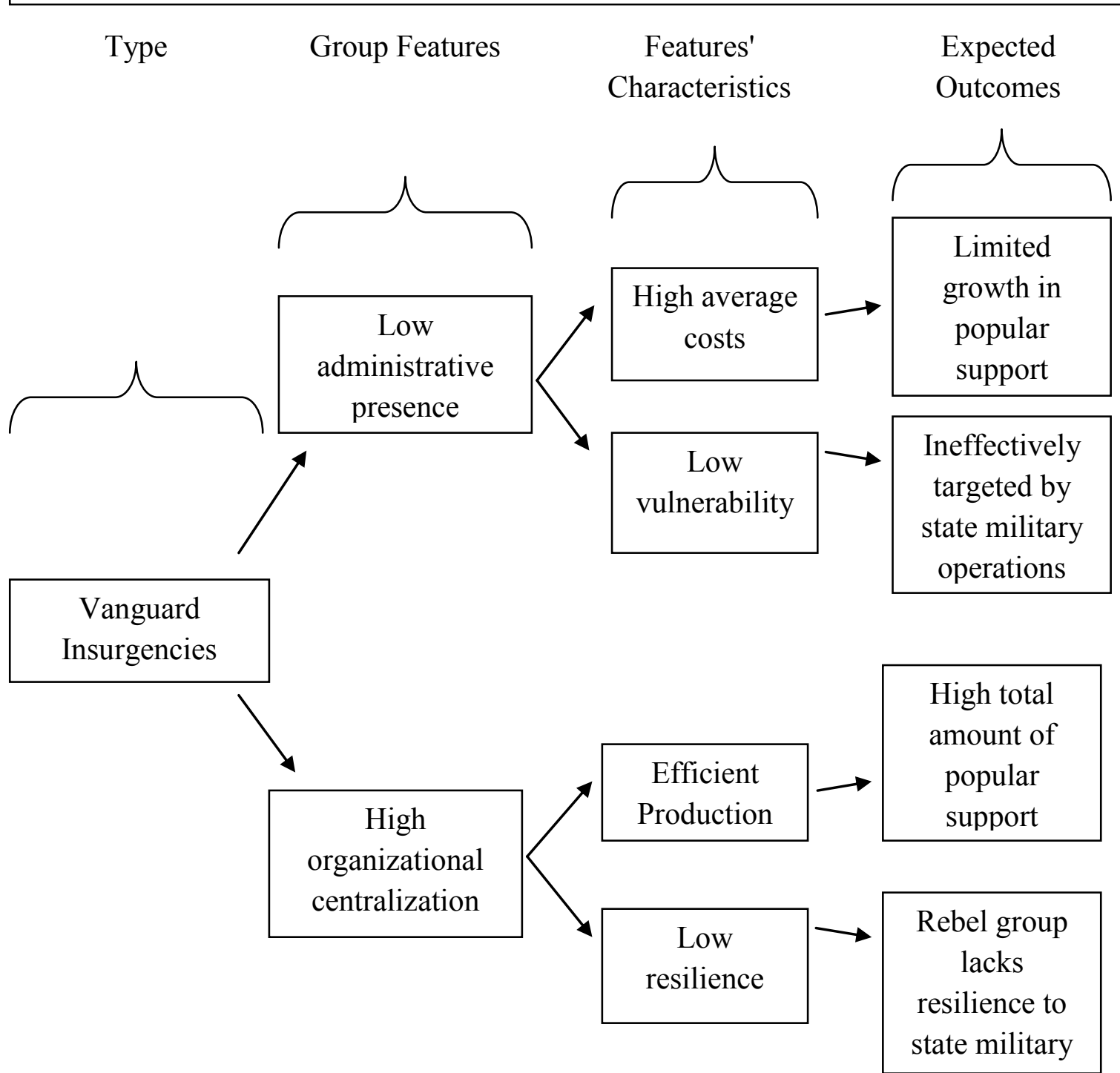

Figure 6.2 summarizes the general relationship between a vanguard insurgency's

features (low administrative presence and high level of organizational centralization) and conflict outcome. The predicted outcomes of what should be observable in a particular conflict are, once again, presented in the far right hand side of the figure. In general terms, the expectation would be that vanguard insurgencies should have a limited ability to produce popular support-securing outputs, which should limit the overall growth of the insurgency. At the same time, the high level of organizational centralization that is 
characteristics of this type of group should result in fairly efficient behaviour, which should improve the ability of the insurgency to grow in size for any given level of production by lowering its variable production costs. Focusing in on the interaction of the insurgency and the state, the low administrative presence of a vanguard insurgency should make it hard for the state to effectively target these sorts of groups. Empirically, this should mean that the state relies upon large scale and largely indiscriminate tactics, as discriminate targeting of insurgents and their infrastructure should be difficult. The high level of organizational centralization indicative of this form of insurgency should mean that vanguard insurgencies lack resilience when they are effectively targeted, with a decline in activity or outright group collapse being two primary empirical expectations.

\subsection{1 - The Shining Path in Peru, 1980 to 1993}

An example of a vanguard-type insurgency is Peru's Sendero Luminoso or the Shining Path. The Shining Path first acted in 1980, when it burned electoral ballot boxes in Chuschi, and was all but destroyed by 1993. The Shining Path emerged, unlike the other three cases under consideration here, in a mobilization context that was not completely favourable to insurgency. Before the Shining Path initiated its violent campaign, economic conditions had deteriorated during the course of the 1970s, while democratic government returned to the country in 1979. These divergent features of the mobilization context in Peru conditioned the population's baseline preference for revolution in different ways. Peru's poor economic performance, outrageously high inflation, and high unemployment created a pool of resentment that made rebel promises of an alternative political and economic arrangement attractive. The re-emergence of democracy in Peru had the opposite effect, essentially providing a peaceful outlet through which peasants 
and other disenfranchised groups could pursue their political objectives. ${ }^{420}$ Given, as Cynthia McClintock points out, that most peasants believed that the Peruvian state lacked legitimacy despite the changes that occurred to the political regime in 1979, economic hardships outweighed any of the suppress effects that democracy had on the population's preference for revolution. ${ }^{421}$ Put otherwise, the net effect of these two macro-level trends was to condition the population's initial preferences in favour of rebellion, although the total effect was likely smaller than if democratic government had not been reintroduced. ${ }^{422}$ Favourable preferences for rebellion made popular support cheaper for the Shining Path insurgency than would otherwise have been the case. From its early beginnings, Sendero Luminoso was able to grow quite rapidly. By the early 1990s, the insurgency had between roughly 10,000 to 23,000 guerrilla soldiers. ${ }^{423}$ In September of 1992, the leader of the Shining Path, Abimael Guzman, was captured in a Lima apartment house. The organizational structure of Sendero Luminoso quickly disintegrated after his capture. By 1993, the Shining Path was all but defeated.

\footnotetext{
${ }^{420}$ On the state of Peru's nascent democracy, see Cynthia McClintock, Revolutionary Movements in Latin America (Washington: United States Institute of Peace Press, 1998), 93-154. On the idea that nascent rebels chose their course of action by weighting the costs and benefits of peaceful versus violent action, that is, that the two are substitutes, see Mark Irving Lichbach, "Deterrence or Escalation? The Puzzle of Aggregate Studies of Repression and Dissent," Journal of Conflict Resolution, Vol. 31, no 2. (1987), 266297. For an empirical test of Lichbach's theory, see Will H. Moore, "Repression and Dissent: Substitution, Context, and Timing," American Journal of Political Science, Vol. 42, no. 3 (1998), 851-873.

${ }^{421}$ Cynthia McClintock, Revolutionary Movements in Latin America (Washington: United States Institute of Peace Press, 1998), 93-154.

${ }^{422}$ Jon Elster calls this sort of scenario (where two effects are triggered that have countervailing effects) the operation of "type B mechanisms." Basically, the net effect in these scenarios is unclear ex ante. See Jon Elster, "A Plea for Mechanisms," in Peter Hedstrom and Richard Swedberg eds., Social Mechanisms: An Analytical Approach to Social Theory (Cambridge: Cambridge University Press, 1998), 50.

${ }^{423}$ For the estimate of 10,000, see Cynthia McClintock, Revolutionary Movements in Latin America (Washington: United States Institute of Peace Press, 1998), 73. For the estimate of 23,000, see James F. Rochlin, Vanguard Revolutionaries in Latin America: Peru, Colombia, Mexico (Boulder: Lynne Rienner Publishers, 2003), 39.
} 
During the course of the insurgency, the Shining Path's administrative presence expanded from its humble beginnings in the poor, rural department of Ayacucho in 1980 to a national scope by the end of $1985 .^{424}$ The insurgency remained more-or-less national in scope until the early 1990s. ${ }^{425}$ The Shining Path expanded its administrative presence largely by displacing local political authority and replacing it with its own popular committees. As Lewis Taylor puts it, "A key component of Abimael Guzman's policy of 'churning up the countryside' involved the 'cleansing' (i.e., elimination) of the Peruvian state from rural districts. ${ }^{426}$ Once it had entered into an area and removed some of the state's presence, the insurgency would set up a 'people's committee'. An amalgamation of a few dozen of these people's committees formed a 'support base.' By February of 1990, there were 24 support bases across Peru. ${ }^{427}$ As it expanded, the Shining Path did not really attempt to amalgamate pre-existing socio-political groups into its organizational structure to any significant extent, which meant that it usually had to pay the entire cost of establishing a new cell as its geographical scope expanded. ${ }^{428}$

Despite this geographically broad administrative breadth, the Shining Path's administrative structures were typically lacking in depth. Certainly, the administrative presence of the insurgency was more concentrated in some regions rather than others. At

\footnotetext{
${ }^{424}$ Jeremy Weinstein, Inside Rebellion: The Politics of Insurgent Violence (New York: Cambridge University Press, 2009), 85.

${ }^{425}$ Although this means the Shining Path maintained a presence in most every department in Peru, it does not mean that it was active everywhere at all times.

${ }^{426}$ Lewis Taylor, Shining Path: Guerrilla War in Peru's Northern Highlands, 1980-1997 (Liverpool: Liverpool University Press, 2006), 103.

${ }^{427}$ Simon Strong, Shining Path: Terror and Revolution in Peru (New York: Times Books, 1992 ), 87.

${ }^{428}$ For evidence on the Shining Path's limited use of "voluntary associations" and the relationship of this choice to conflict outcome, see Ogen Goldman, "The Importance of Voluntary Associations For Guerrilla Movements," Studies in Conflict and Terrorism, Vol. 36, no. 10 (2013), 789-818. For details on some of the organizations that were incorporated into the Shining Path's organization, see Michael Radu and Vladimir Tismaneanu, Latin American Revolutionaries: Groups, Goals, Methods (Washington: Pergamon-Brassey's, 1990), 324-325.
} 
the time of its peak size and capacity around 1990, Sendero Luminoso had an estimated 23,430 guerrilla fighters. It was also supported by a civilian network of between 50,000 to 100,000 people. The depth of the Shining Path's support base varied, however, and upwards of 86 percent of its guerrilla fighters were located in the departments of Ayacucho, Huancavelico, Apurímac, Junín, and Pasco. ${ }^{429}$ By this count, the rest of the country had only 14 percent of the armed insurgents. Certainly, areas with larger populations should likely result in a larger insurgent presence, everything else being equal. Yet, to the extent that the concentration of Shining Path fighters was a product of the rebel group's localized administrative presence (with some additional part of the calculation depending on the distribution of state forces across the country), it is quite likely that the insurgency only had a significant administrative depth in these five departments. Other departments, by extension, had a far thinner administrative depth, even if the rebel group was still present to some extent.

Additional evidence is also consistent with this assessment that the administrative depth of the Shining Path was fairly limited in most parts of Peru. Since an insurgency must necessarily displace the state in an area if it is to fully develop its administrative presence, a clear empirical expectation would be that the state should lack control of any areas where the Shining Path had a large-scale administrative presence. Evidence collected by Cynthia McClintock and her research team shows that in 1989 only 28 percent of Peru's municipalities were under the control of the insurgency, suggesting that the insurgency did not develop a particularly deep administrative presence in over two

\footnotetext{
${ }^{429}$ James F. Rochlin, Vanguard Revolutionaries in Latin America: Peru, Colombia, Mexico (Boulder: Lynne Rienner Publishers, 2003), 39.
} 
thirds of the country. ${ }^{430}$ Likewise, only one third of Peru's departments were under a State of Emergency in 1989. ${ }^{431}$ Overall, the administrative presence of the Shining Path of Peru was certainly broad, but not particularly deep in a majority of the country.

In an effort to secure the support of the population, Sendero Luminoso used its limited administrative presence to produce a fairly minor amount of remunerative compensation and a fair amount of preference manipulation tactics. ${ }^{432}$ Typically, the Shining Path provided a few services in an effort to purchase popular support, with the provision of justice and law enforcement being particularly common. ${ }^{433}$ In the coca rich Upper Huallaga Valley, the Shining Path also protected the population from both the state and the Colombian drug traffickers in exchange for a portion of the profits garnered from the sale of illicit drug crops. ${ }^{434}$ Such actions reportedly netted Sendero Luminoso something on the order of an estimated 20 to 30 million U.S. Dollars per annum, although estimates vary widely. ${ }^{435}$ It also organized and provided armed assistance to the peasantry if it undertook spontaneous land invasions. Additionally, particularly later on in the insurgency, the Shining Path would pay its membership a salary of between $\$ 250$ and \$500 dollars a month, which was quite rich for Peruvian standards at the time. ${ }^{436}$ Despite

\footnotetext{
${ }^{430}$ Cynthia McClintock, Revolutionary Movements in Latin America (Washington: United States Institute of Peace Press, 1998), 73, Table 2.1.

${ }^{431}$ Gabriela Tarazona-Sevillano, Sendero Luminoso and the Threat of Narcoterrorism (New York: Praeger 1990), 94.

${ }^{432}$ For a detailed account of how the peasantry wanted more services and how the Shining Path failed to provide them, see Lewis Taylor, Shining Path: Guerrilla War in Peru's Northern Highlands, 1980-1997 (Liverpool: Liverpool University Press, 2006),163-167.

433 Jeremy Weinstein, Inside Rebellion: The Politics of Insurgent Violence (New York: Cambridge University Press, 2009), 85.

${ }^{434}$ Jose E. Gonzales, "Guerrillas and Coca in the Upper Huallaga Valley," in David Scott Palamer, ed., Shining Path of Peru (New York: St. Martin's Press, 1992), 108.

435 James F. Rochlin, Vanguard Revolutionaries in Latin America: Peru, Colombia, Mexico (Boulder: Lynne Rienner Publishers, 2003), 42.

${ }^{436}$ Cynthia McClintock, Revolutionary Movements in Latin America (Washington: United States Institute of Peace Press, 1998), 73.
} 
the clear presence of some minimal levels of remunerative compensation provision, the rebellion was not consistent in its provision of these services and material benefits. For example, in Puno, the insurgency "supported the peasants in a number of land invasions, but proved unable to protect them when government forces reacted." ${ }^{437}$ Additionally, unlike many other insurgencies, the Shining Path did not provide the population with much education (as a service, at least, although it did use extensive ideological programs) or any significant health or veterinary care. Failing to provide these more costly services was at least partially a result of the limited administrative presence that the rebellion developed in most areas, which resulted in prohibitively high costs of producing these services.

Sendero Luminoso used fairly extensive preference manipulation tactics to mobilize popular support. The Shining Path often coerced the local population into supporting the rebellion, usually demanding their silence or the provision of information on state activity and material goods such as food or shelter. Indeed, an integral part of the Shining Path's administrative structure were the so-called "Annihilation Squads," which were "used for the murder of prominent government or opposition members and for the execution of alleged traitors to Sendero." ${ }^{438}$ The rebellion also undertook an extensive program of ideological indoctrination (preference manipulation tactics), which it applied in an effort to convince the population of the virtue of Guzman's version of revolutionary

\footnotetext{
${ }^{437}$ David Scott Palmer, "The Revolutionary Terrorism of Peru's Shining Path," in Martha Crenshaw, ed., Terrorism in Context (Pennsylvania: The Pennsylvania State University Press, 2007), 286-287.

${ }^{438}$ Michael Radu and Vladimir Tismaneanu, Latin American Revolutionaries: Groups, Goals, Methods (Washington: Pergamon-Brassey's, 1990), 331. Emphasis added.
} 
Maoism. ${ }^{439}$ Despite producing some remunerative compensation and a fair amount of preference manipulation tactics, the extent of popular support that the insurgency obtained remained bounded by its limited supply of popular support-securing outputs. Cynthia McClintock, for example, estimates that, in 1989, Sendero Luminoso wielded the support of only an estimated 15 percent of the population, despite controlling 28 percent of Peruvian municipalities. This contrasts unfavourably with the FMLN in El Salvador, which controlled only 15 percent of the municipalities and commanded roughly 25 percent of the population's allegiances. ${ }^{40}$ The Shining Path lacked a truly strong base of popular support, which bespeaks to their limited provision of popular support-securing outputs. $^{441}$

The fairly small-scale administrative presence of the Shining Path inhibited the ability of the state to effectively target the rebellion, particularly due to insurgency's lack of any real administrative depth in most areas. In other words, the insurgency was not particularly vulnerable because its small-scale administrative presence allowed it to retain its mobility and limited the contrast between its organizational presence and the local population. For example, retaining its mobility, the Shining Path routinely abandoned the peasantry to the machinations of the state and easily avoided government patrols, although this did undermine the population's willingness to support the insurgency later

\footnotetext{
${ }^{439}$ On the ideological indoctrination used by the Shining Path, particularly its relationship to Inca mythology, see Simon Strong, Shining Path: Terror and Revolution in Peru (New York: Times Books, 1992), 32-63.

${ }^{440}$ Cynthia McClintock, Revolutionary Movements in Latin America (Washington: United States Institute of Peace Press, 1998), 73, Table 2.1.

${ }^{441}$ On the basis of this review, I assigned the following scores to the four coding components of a rebel group's administrative presence the following values: political associations $(0.4)$, remunerative compensation infrastructure (0.2), preference manipulation capacity (0.6), geographical scope (0.7). Employing the coding procedure outlined above, the summation of these values and the division of that total by the number of operational components results in an aggregate score of 0.475 for the Shining Path's administrative presence. In other words, the administrative presence of the Shining Path when assessed at its peak and at the national level is low, although it is quite close to the 0.5 cut-off point.
} 
on. ${ }^{442}$ Ronald Berg also notes the minimal contrast between the guerrillas and the people quite well, stating, "The police were unsuccessful in their efforts to identify or capture Sendero militants. Rather, many suspects were rounded up in hopes of capturing a few active guerrillas." 443

The state, as a result of the rebellion's small-scaled administrative presence, had to rely, as would be expected, upon highly indiscriminate force that failed to distinguish between the insurgents and the bulk of the population. ${ }^{444}$ As one analysis puts it, "Army officers and soldiers in turn were frustrated by their complete inability to distinguish members of the insurgency from local inhabitants. Their rage was unleashed in largely futile attempts to strike back at the subversive movement." ${ }^{445}$ After the military launched its first efforts at contending with the insurgency in 1984, indiscriminate violence and civilian casualties mounted precipitously before gradually falling in the following years. ${ }^{446}$ Deaths from state violence leaped immediately in 1984 to 4,319 . In subsequent years, the death rate remained high, with 1,359 suspected deaths in 1985 and 1,268 deaths in $1986 .{ }^{447}$ Granted, during this period some data suggests that the percentage of total deaths (not just civilian deaths noted above) made up by "presumed subversives" was as

\footnotetext{
442 Lewis Taylor, Shining Path: Guerrilla War in Peru's Northern Highlands, 1980-1997 (Liverpool: Liverpool University Press, 2006), 25.

${ }^{443}$ Ronald H. Berg, "Peasant Responses to Shining Path in Andahuaylas," in David Scott Palmer ed., Shining Path of Peru (New York: St. Martin's Press, 1992), 95.

444 Ibid; Lewis Taylor, Shining Path: Guerrilla War in Peru's Northern Highlands, 1980-1997 (Liverpool: Liverpool University Press, 2006), 112; Simon Strong, Shining Path: Terror and Revolution in Peru (New York: Times Books, 1992), 134.

${ }^{445}$ Gabriela Tarazona-Sevillano, Sendero Luminoso and the Threat of Narcoterrorism (New York: Praeger 1990), 91.

${ }^{446}$ Prior to the military becoming involved, the police were left to confront Sendero alone.

${ }^{447}$ James F. Rochlin, Vanguard Revolutionaries in Latin America: Peru, Colombia, Mexico (Boulder: Lynne Rienner Publishers, 2003), 65.
} 
high as 62 percent in 1983, 48 percent in 1984, and 44 percent in $1985 .{ }^{448}$ Like most body count figures that are meant to express how many 'terrorists', 'insurgents', 'guerrillas,' or, in this case, "presumed subversives" are being killed, the numbers are likely inflated to a significant, but largely unknown, extent. Regardless, in line with the mobilization and conflict outcome theory, evidence does suggest that the small scale of the Shining Path's administrative structure did limit the state's ability to find and pin-down the organization of the insurgency. Conceptualized from the insurgency's perspective, the Shining Path was not particularly vulnerable to being targeted by state forces, for it easily avoid its adversaries due to a high degree of mobility and its low contrast with the population.

As a vanguard insurgency, Sendero Luminoso had a highly centralized organizational structure. ${ }^{449}$ Sendero Luminoso adopted what its leader, Abimael Guzman, called the axiom of "strategic centralization and tactical decentralization." ${ }^{450}$ This organizational schema resulted in a ridged hierarchical organizational structure, with the devolution of day-to-day tactical decisions to local cell commanders. In this hierarchical structure, the central committee, headed by Guzman himself, directed the activity of the regional committees, which, in turn, directed the zonal committees. The zonal committees, finally, directed the individual Sendero Luminoso cells. ${ }^{451}$ The reliance upon

\footnotetext{
${ }^{448}$ David Scott Palmer, "The Revolutionary Terrorism of Peru's Shining Path," in Martha Crenshaw eds., Terrorism in Context (University Park: The Pennsylvania State University Press, 2007), 274, Table 7.4.

${ }^{449}$ As Jeremy Weinstein notes, there was regional variation in the degree to which the organizational structure of the Shining Path was centralized and how good its organizational features operated. However, assessed on a national level, the group was quite centralized as the following evidence suggests. See, Jeremy Weinstein, Inside Rebellion: The Politics of Insurgent Violence (New York: Cambridge University Press, 2009).

${ }^{450}$ Cited in, David Scott Palmer, "The Revolutionary Terrorism of Peru's Shining Path," in Martha Crenshaw eds., Terrorism in Context (University Park: The Pennsylvania State University Press, 2007), 283.

${ }^{451}$ David Scott Palmer, "The Revolutionary Terrorism of Peru's Shining Path," in Martha Crenshaw eds., Terrorism in Context (University Park: The Pennsylvania State University Press, 2007), 269; James F. Rochlin, Vanguard Revolutionaries in Latin America: Peru, Colombia, Mexico (Boulder: Lynne Rienner
} 
hierarchical decision-making made the Shining Path a highly efficient organization. As Cynthia McClintock describes it:

The Shining Path was an authoritarian organization dominated by one man, Abimael Guzman. From 1980 until 12 September 1992 [when Guzman was captured], authoritarianism appeared to abet the organization's advance. ... Having one man decide what was right and what was wrong enabled the organization to be cohesive, purposeful, and efficient. ${ }^{452}$

The Shining Path also relied on a specialized division of labour in order to promote its organizational efficiency. As James F. Rochlin aptly puts it, "Centralized under the command of Guzman, the group's pyramid structure featured a variety of specialized and efficient departments." ${ }^{453}$ The central committee, for example, was responsible for providing overall strategic direction to the insurgent organization. The zonal committees and the cells that they presided over were mainly involved in the production of preference manipulation tactics and the mobilization of popular support. ${ }^{454}$ By the early 1990s, Sendero Luminoso also developed a series of organizations to coordinate between the central committee's directives and lower level operational activities. ${ }^{455}$ The Shining Path developed strict rules and many mechanisms to both monitor and control its membership, although some parts of the organization were better

Publishers, 2003), 58-59; Gabriela Tarazona-Sevillano, Sendero Luminoso and the Threat of Narcoterrorism (New York: Praeger 1990), 57.

${ }^{452}$ Cynthia McClintock, Revolutionary Movements in Latin America (Washington: United States Institute of Peace Press, 1998), 91.

453 James F. Rochlin, Vanguard Revolutionaries in Latin America: Peru, Colombia, Mexico (Boulder: Lynne Rienner Publishers, 2003), 58. Emphasis added.

${ }^{454}$ Gabriela Tarazona-Sevillano, Sendero Luminoso and the Threat of Narcoterrorism (New York: Praeger 1990), 61.

${ }^{455}$ Gabriela Tarazona-Sevillano, "The Organization of Shining Path," in David Scott Palmer ed., Shining Path of Peru (New York: St. Martin's Press, 1992), 173; David Scott Palmer, "The Revolutionary Terrorism of Peru's Shining Path," in Martha Crenshaw, ed., Terrorism in Context (Pennsylvania: The Pennsylvania State University Press, 2007), 267-268. 
controlled than others. ${ }^{456}$ As Guzman himself once put it, "We must impose discipline with rigor no matter what the cost." ${ }^{457}$ In short, Sendero Luminoso was a very centralized organization with hierarchical decision-making, clear coordination mechanisms, specialized organizational subunits, and control and monitoring mechanisms.

These organizational features helped the Shining Path efficiently and effectively produce what little remunerative compensation the group did provide. It also made the use of preference manipulation tactics more efficient by harmonising both the message behind the propaganda and the aim of the coercive violence that Sendero Luminoso routinely employed. Evidence also suggests that, in addition to centralization facilitating the efficient production of popular support-securing outputs, the few remaining decentralized elements of the insurgency, like its cellular organization at the local level, limited "the [insurgency's] mobilization of mass support." ${ }^{458}$ Consistent with the mobilization and conflict outcome theory, the evidence presented here suggests that the insurgency was more efficient due to its organizational centralization, but retained certain inefficiencies that limited its ability to mobilize popular support due to its decentralization at the tactical level.

The final empirical prediction is that a vanguard-type rebel group should lack resilience when effectively targeted by state military force. There are two observable predictions here. First, if pressured militarily, the group should be prone to collapse. Second, if the organization is targeted, it should disrupt the operation of the insurgency,

\footnotetext{
${ }^{456}$ Jeremy Weinstein, Inside Rebellion: The Politics of Insurgent Violence (New York: Cambridge University Press, 2009).

${ }^{457}$ Abimael Guzman, cited in, Jeremy Weinstein, Inside Rebellion: The Politics of Insurgent Violence (New York: Cambridge University Press, 2009), 154.

${ }^{458}$ Ronald H. Berg, "Peasant Responses to Shining Path in Andahuaylas," in David Scott Palmer ed., Shining Path of Peru (New York: St. Martin's Press, 1992), 103.
} 
resulting in a decline in both the quality and quantity of guerrilla activity. All of these expectations fit well with the evidence from the Shining Path insurgency's rapid demise in the early 1990 s.

On 12 September, 1992, Sendero Luminoso's leader, Abimael Guzman, was captured in a Lima apartment building. Following his capture, state forces were able to able to round up upwards of 300 senior leaders of the Shining Path, further pressuring the integrity of the organization. ${ }^{459}$ The months leading up to the effective decapitation of the organization were increasingly violent, with the insurgency launching several large-scale attacks that had placed the Peruvian military on its heels. ${ }^{460}$ Ultimately, however, the Shining Path broke under the pressure that was placed against its organization. As one characterisation puts it,

Sendero Luminoso fell apart when Guzman was captured. This godlike figurehead was instantly demoted to the position of incarcerated thug. Sendero's support base, having been the subject of dictation, did not know how to act when its director was jailed. Thus the combination of dictatorship and commensurate lack of autonomous power among members represented a crucial weakness for Sendero. ${ }^{461}$

The membership of the Shining Path also defected in droves after Guzman was captured. Defecting insurgents tended to start cascades of defection that rapidly weakened the rebel group, which was a fairly cost free option given the Shining Path's emergent organizational incoherence (which limited the group's ability to punish defectors) and the state's adoption of the Repentance Law, which gave

\footnotetext{
${ }^{459}$ David Scott Palmer, "The Revolutionary Terrorism of Peru's Shining Path," in Martha Crenshaw, ed., Terrorism in Context (Pennsylvania: The Pennsylvania State University Press, 2007), 301.

${ }^{460}$ For a detailed description of the months leading up to the capture of Guzman, see Cynthia McClintock, Revolutionary Movements in Latin America (Washington: United States Institute of Peace Press, 1998), 8689.

461 James F. Rochlin, Vanguard Revolutionaries in Latin America: Peru, Colombia, Mexico (Boulder: Lynne Rienner Publishers, 2003), 49.
} 
amnesty to former guerrillas. For example, while few insurgents turned themselves in during 1992, some 68 surrendered in 1993. Between January and October of 1994, the number of defections had increased to 292, a year-overyear increase of 330 percent. ${ }^{462}$ In short, pressured by state military activity, the mutual reliance of the organization was eroded and its membership felt comfortable to defect.

The capture of Guzman also disrupted the activity of the Shining Path across the country, with a decline in both the number of and the lethality of militant attacks. As Table 6.3 shows, from April 1992 to the month of Guzman's capture in September, there was a generally escalatory trend in both insurgent-launched incidents and fatalities due to militant attacks. Following Guzman's capture, there is a two-month spike in incidents and fatalities, before the total number of both decline significantly. It is plausible that the short run activity witnessed after Guzman's capture is the result of a combination of preplanned attacks being carried out and the spontaneous outburst of insurgent activity in retaliation for the capture of the Shining Path leadership. Indeed, Guzman reportedly told the Shining Path membership to undertake the already planned "sixth military campaign" from his jail cell on October 7, 1992. ${ }^{463}$

After Guzman's capture, the number of attacks dropped by 9 percent, falling from 944 incidents in the six months prior to his capture to 862 in the six months following. ${ }^{464}$ Even more telling, the number of deaths due to insurgent activity fell by a full 24 percent, with the average number of deaths per attack falling from 1.26 in the months leading up

\footnotetext{
${ }^{462}$ Lewis Taylor, Shining Path: Guerrilla War in Peru's Northern Highlands, 1980-1997 (Liverpool: Liverpool University Press, 2006), 174.

${ }^{463}$ Simon Strong, Shining Path: Terror and Revolution in Peru (New York: Times Books, 1992), 270.

${ }^{464}$ An unpaired 1 tail T-test returns a p-statistic of 0.37 , which indicates that this finding is not statistically significant in a classical sense.
} 
to the capture of the Shining Path leadership to 1.05 in the months following.

Additionally, the results of an unpaired 1-tail t-test comparing the first six months to the second six month period returns a p-statistic of 0.048 , which indicates that the drop in deaths was statistically significant. Clearly, the effective targeting of the Shining Path insurgency disrupted the group's organizational processes and undermined (somewhat) its ability to launch attacks at all and undermined significantly its ability to launch effectively coordinated and executed attacks. These findings are in line with the core expectation that Sendero Luminoso, as a centralized rebel organization, was not particularly resilient to being targeted by state military forces.

Table 6.3. Incidents and Deaths by Month, April 1992-March 1993

\begin{tabular}{|c|c|c|}
\hline & Incidents & Deaths \\
\hline April & 119 & 133 \\
\hline May & 151 & 379 \\
\hline June & 96 & 168 \\
\hline July & 296 & 191 \\
\hline August & 117 & 173 \\
\hline September & 165 & 149 \\
\hline $\begin{array}{l}\text { Six-month totals (to } \\
\text { Guzman capture) }\end{array}$ & $944 *$ & 1,193 \\
\hline October & 119 & 175 \\
\hline November & 272 & 254 \\
\hline December & 167 & 89 \\
\hline January & 154 & 157 \\
\hline February & 72 & 153 \\
\hline March & 78 & 79 \\
\hline $\begin{array}{l}\text { Six-month total (since } \\
\text { Guzman capture) }\end{array}$ & 862 & 907 \\
\hline $\begin{array}{l}\text { Percentage change from } \\
\text { first six months to second }\end{array}$ & - 9 percent change & - 24 percent change \\
\hline \multicolumn{3}{|c|}{$\begin{array}{l}\text { This table is taken from David Scott Palmer, "The Revolutionary Terrorism of Peru's } \\
\text { Shining Path," in Martha Crenshaw, ed., Terrorism in Context (Pennsylvania: The } \\
\text { Pennsylvania State University Press, 2007), 284, Table } 7.5 \\
\text { * The original table indicated that the sum of the first six months was } 924 \text {. This was a } \\
\text { small miscalculation that was not actually used in the original calculation of the } \\
\text { percent change between the two periods. The correct figure for the first six months is } \\
944 \text {. }\end{array}$} \\
\hline
\end{tabular}


The case study of Sendero Luminoso in Peru shows that all four predicted outcomes are fairly well supported. The insurgency was limited in its production of popular support-securing outputs, was hard for the state to target, was fairly efficient at production, and did collapse rapidly when the group was effectively targeted. In sum, the evidence from this case strongly supports the internal validity of the mobilization and conflict outcome theory.

In sum, in the case of a vanguard insurgency, the typological formulation of the mobilization and conflict outcome theory predicts four outcomes. First, due to its small scale administrative presence, the insurgency should produce few popular supportsecuring outputs, which limits the amount of popular support the insurgency receives. Second, again as a result of its small scale administrative presence, the insurgency should be fairly invulnerable to being targeted by state military activity, which results in poorly targeted state violence. Third, the insurgency should be fairly efficient in its production of popular support-securing outputs, due to its centralized organizational structure. Finally, because centralization limits a group's resilience to being targeted militarily, vanguard insurgencies should be prone to disruption and collapse if they are targeted effectively by military force.

\section{4 - Fragmented Insurgencies}

Fragmented insurgencies have a high administrative presence and a low level of organizational centralization. Fragmented insurgencies are likely to grow at a moderately fast rate because of their large administrative presence, high production capacity, and the probable presence of economies of scale in the production of popular support-securing 
outputs, which distributes a group's fixed costs over a large number of outputs. At the same time, due to the inefficient nature of their decentralized organizational structure, fragmented insurgencies are likely to be limited in their growth of popular support because of their inherent inefficiencies. Fragmented insurgencies are also likely to be fairly vulnerable to being targeted by state military forces and fairly resilient in the face of state military pressure. This combination of characteristics makes fragmented insurgencies difficult to defeat without significant military pressure, as the insurgency can quite rapidly regenerate its membership and is organizationally resilient. Moreover, since fragmented insurgencies likely obtain a fair amount of popular support, their chances of winning are greater than a diffuse insurgency, other things being equal. 


\section{Figure 6.3. Fragmented Insurgencies}

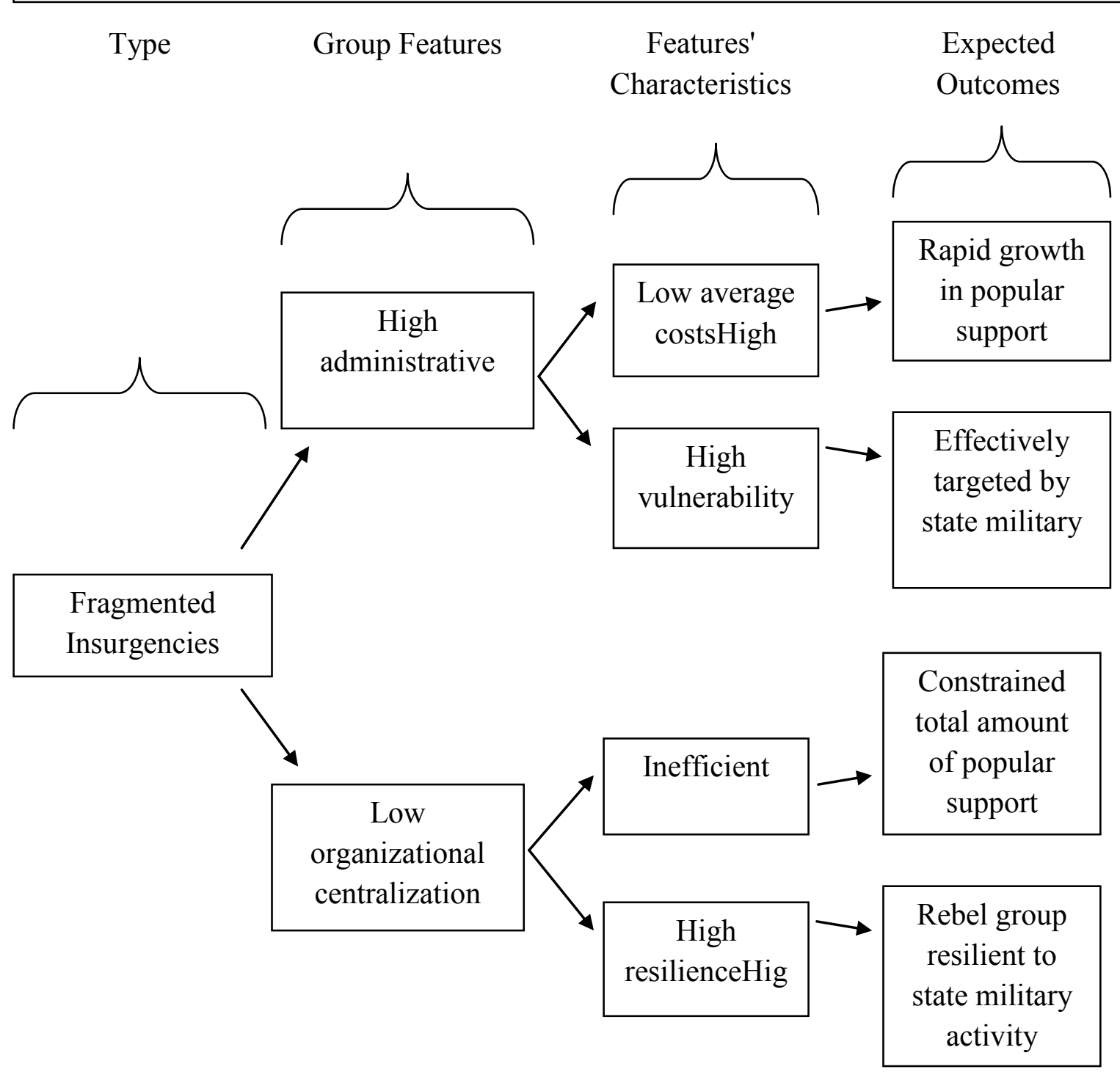

Figure 6.3 summarizes the general causal relationship between a fragmented insurgency's high administrative presence and its low organizational centralization and its ability to obtain popular support and its position relative to the state. The figure also depicts the general expectation of what should happen during the course of a fragmented insurgency's challenge to the state. The general predictions of what a conflict involving a fragmented insurgency should look like are, once again, outlined in the far right-hand 
side of the figure. In general, fragmented insurgencies should be able to mobilize popular support fairly rapidly due to their large-scale administrative presence, but this rate of mobilization should be limited by group inefficiencies. The state should find it fairly easy to target a fragmented insurgency because of the rebel group's large-scale administrative presence, but the insurgency should also be fairly resilient in the face of military pressure due to its low level of organizational centralization.

\subsection{1 - The Afghan Mujahideen against the Soviets, 1978-1989}

An example of a fragmented insurgency is the Mujahideen in Afghanistan. ${ }^{465}$ The Mujahideen insurgency emerged within a favourable mobilization context. The Afghan people had - and continue to have - a strong sense of localised identity, and, at best, only weak connections to the central government. When the Soviet-backed People's Democratic Party of Afghanistan (PDPA) took power in 1978, they instituted a series of socio-political reforms that brought the central government into direct confrontation with rurally based tribes, often resulting in violent confrontations. The effect of these imposed reforms, as explained by Gerard Chaliand, was to unify "villagers and even entire tribes around local leaders opposed to the central authority of the state. What they resented most was the outsiders' intervention in tribal and regional affairs where they were used to governing autonomously." ${ }^{466}$ The direct intervention of the Soviet Union in December of 1979 further conditioned the population's preferences toward favourably supporting the

\footnotetext{
${ }^{465}$ See Eric Jardine, "The Tacit Evolution of Coordination and Strategic Outcomes in Highly Fragmented Insurgencies: Evidence from the Soviet War in Afghanistan," Journal of Strategic Studies, Vol. 35, no. 4 (2012), 541-572. For a lucid within-case comparison of the relative effectiveness of the different commanders leading differently organized rebel groups within Afghanistan, see Abdulkader H. Sinno, Organizations at War: In Afghanistan and Beyond (Ithaca: Cornell University Press, 2008).

${ }^{466}$ Gerard Chaliand, Report from Afghanistan, Tamar Jacoby trans., (New York: Viking Books, 1982), 37-38.
} 
insurgency. The Mujahideen insurgency, which emerged to confront the PDPA and the Soviets, had a large-scale administrative presence and a low level of organizational centralization. In 1989, the Mujahideen were able to successfully expel the Soviets after 10 long years of war, although they were unable to consolidate their position and were eventually beaten by the emergent Taliban insurgency in 1996 .

After the PDPA's seizure of power, the Mujahideen insurgency rapidly emerged. The administrative presence of the insurgency was based upon local solidarity networks known as Qawms. The insurgency expanded its administrative presence largely through the incorporation of these pre-existing socio-political networks, rather than through much original organization building, although some commanders, such as Ismail Khan in Herat, Gulbuddin Hekmatyar, and Ahmed Shah Massoud in Panjshir, built more original organizational and administrative structures in the areas that they controlled. ${ }^{467}$ In areas where the insurgency was mainly an outgrowth of pre-existing socio-political networks, the production of popular support-securing outputs occurred via traditional communitybased mechanisms. In areas where more original insurgent organization had been developed, the insurgent commanders produced popular support-securing outputs using their newly develop administrative structures in an effort to obtain popular support. ${ }^{468}$ As expected by the mobilization and conflict outcome theory, the Mujahideen's expansion via the incorporation of pre-existing Qawm ties reduced the overall cost of the rebellion.

\footnotetext{
${ }^{467}$ On the organization building of Ismail Khan and Ahmed Massoud, see Gilles Dorronsoro, Revolution Unending: Afghanistan, 1979 to the Present (New York: Columbia University Press, 2005), 125-129; on Gulbuddin Hekmatyar, see Abdulkader H. Sinno, Organizations at War: In Afghanistan and Beyond (Ithaca: Cornell University Press, 2008), 153-154.

${ }^{468}$ Ibid, 152-158.
} 
As Abdulkaher H. Sinno puts it, "the Mujahideen were able to mobilize much of the population at little cost because the close qawm ties." 469

The Mujahideen insurgency quickly developed a significant administrative breadth, particularly in rural areas, with varying levels of administrative depth. By the 1980s, all of Afghanistan's provinces were afflicted with insurgent activity and there were several thousand active Mujahideen commanders throughout the country. ${ }^{470}$ The depth of the Mujahideen's administrative presence varied, with some commanders leading upwards of 10,000 men, while others consisted of only "a village notable at the head of a handful of [Mujahideen]." ${ }^{471}$ The large scale of the insurgency's administrative presence throughout the country meant that the insurrection grew at a fairly fast rate and could rapidly replace the capacity that it lost in engagements with state forces. ${ }^{472}$

In addition to increasing the rate at which popular support was obtained by the insurgency, the Mujahideen's large-scale administrative presence also increased the ability of the regime's counterinsurgent forces to target the rebellion's organization, support base, infrastructure, and assets. The resistance's large administrative presence meant that the segments of the insurgency were tied to particular areas and held a large responsibility towards the local population, which severely limited the mobility of the different guerrilla armies. The insurgency's vulnerability to attack by state forces was

\footnotetext{
${ }^{469}$ Abdulkader H. Sinno, Organizations at War: In Afghanistan and Beyond (Ithaca: Cornell University Press, 2008), 158.

${ }^{470}$ Estimates on the number of commanders varies. See, for example, Antonio Giustozzi, War, Politics and Society in Afghanistan, 1978-1992 (Washington: Georgetown University Press, 2000), 242.

${ }^{471}$ See, Gilles Dorronsoro, Revolution Unending: Afghanistan, 1979 to the Present (New York: Columbia University Press, 2005), 108.

472 On the basis of this evidence, I coded the Mujahideen insurgency as having the following values on the four components of administrative presence: political associations (0.9), remunerative compensation infrastructure (0.4), preference manipulation tactics (0.6), geographical scope (0.9). Using the coding procedures outlined above, the Mujahideen score of 0.7 on the overall scale of their administrative presence.
} 
made even more pronounced due to the fact that the insurgency often expanded primarily through the incorporation of pre-existing networks, so insurgent commanders were extraordinarily beholden to the local organization for resources and recruits. Moreover, since pre-existing organizations were often dragged into the insurgency directly, the distinction between the rebel group and the socio-political institutions that governed a particular area prior to the conflict were, in some cases, non-existent. The complete fusion between the insurgency and the local socio-political institutions meant that the organization and infrastructure of the insurgency was, after a fashion, well-known to state forces because it was virtually identical to more well-known and well-established forms of socio-political organization that preceded the insurrection. This fusion led to excessively brutal military tactics on the part of Soviet forces, although other factors contributed to this trend as well. Overall, the final result of the Mujahideen's large administrative presence was, as Gilles Dorronsoro puts it, that "The guerrillas did not put a high value on secrecy or mobility, since the government was well aware of their positions on the ground." ${ }^{473}$

As a fragmented insurgency, the Mujahideen, despite some limited and largely ineffectual efforts at organizational centralization via the Peshawar-based parties, was also, as a whole, highly decentralized. ${ }^{474}$ In theory, the organizational decentralization of the insurgency should have limited the overall size of the rebellion and its rate of growth. Two factors make pinpointing these effects difficult in this case. First, the favourable context of the insurgency meant that the population was, by and large, heavily opposed to

\footnotetext{
${ }^{473}$ Gilles Dorronsoro, Revolution Unending: Afghanistan, 1979 to the Present (New York: Columbia University Press, 2005), 207.

${ }^{474}$ On the seven Peshawar-based parties, see Mohammad Yousaf and Mark Adkin, The Battle for Afghanistan: The Soviets Versus the Mujahideen during the 1980s (Barnsley: Pen and Sword, 2009), 37-43.
} 
the regime in Kabul, particularly in rural areas, which made it easier for the insurgency to grow and to reach a large size. Second, the Mujahideen's large-scale administrative presence increased the amount of popular support that was mobilized over time, so that the insurgency grew both rapidly and extensively. Still, within the Mujahideen itself, there is some limited evidence that the commanders of more centralized subunits, such as Ahmed Shah Massoud in Panjshir and Gulbuddin Hekmatyar, who founded Hizb-i Islami, were able to mobilize more popular support than other more internally decentralized segments of the revolt, particularly in areas where the social fabric of the qawms had been disrupted and replace by new organizational patterns. ${ }^{475}$ Tentatively, this internal variation in the level of mobilization between the various subunits of the Mujahideen suggests that had the insurgency as a whole been more centralized, the inefficiently organized subunit could have mobilized more popular support. As these subunits' mobilization of popular support increased, the total level of popular support that the insurgency was able to obtain in the aggregate would have risen as well. The counterfactual prediction is that, had the Mujahideen successfully obtained a more centralized organizational form, they could have mobilized an even higher than of popular support than was otherwise the case. This conclusion is tentative, but in line with the mobilization and conflict outcome theory. ${ }^{476}$

As expected, the lack of organizational centralization increased the resilience of the insurgency in the face of state military pressure. As Abdulkader H. Sinno puts it,

\footnotetext{
${ }^{475}$ Abdulkader H. Sinno, Organizations at War: In Afghanistan and Beyond (Ithaca: Cornell University Press, 2008), 152-158; Gilles Dorronsoro, Revolution Unending: Afghanistan, 1979 to the Present (New York: Columbia University Press, 2005), 108.

${ }^{476}$ The organizational structure of the Mujahideen, as a single insurgency, resulted in the following values on the various operational components of organizational centralization: Specialization (0.3), Coordination mechanisms (0.5), control and monitoring mechanism (0.4), hierarchy (0.4). Following the coding procedures outlined above, this gives the Mujahideen an organizational centralization score of 0.4 .
} 
"The multiplicity of Afghan [M]ujahideen parties and their patronage-based structures deprived the Soviets of shortcuts to end resistance through the assassination of key figures, disarmament, dismantling, or by interrupting their execution of organizational processes.." ${ }^{477}$ Put in the language developed here, the decentralization of the Mujahideen insurrection meant that the vast majority of the localized elements of the insurgency were highly autonomous from one another and could operate effectively even if other parts of the rebellion were successfully targeted and destroyed by state military forces. Indeed, throughout the course of the conflict, the Soviet counterinsurgency applied a significant amount of military pressure and successfully cowed or defeated many commanders - if only for a while. The defeat of a commander in a particular area limited the activity of the insurgency in the host region. However, the activity of other elements of the insurgency was rarely affected by the loss of any individual commander. Each segment of the insurgency usually conducted its own logistical appropriations, strategic planning and fighting, meaning that the insurgency essentially withstood significant military pressure without collapsing. ${ }^{478}$ The inherent resilience of the Mujahideen's organizational structure was significant. Although it was heavily and effectively targeted by Soviet and Afghan forces, the Mujahideen nevertheless withstood the pressure without cascading into collapse.

The Mujahideen in Afghanistan, as a case study of a fragmented insurgency, strongly fits most of the predictions of the typological theory. The one predicted outcome that was only tentatively supported by the evidence was that the organizational decentralization of the insurgency limited the total size of the insurrection. Some

\footnotetext{
${ }^{477}$ Abdulkader H. Sinno, Organizations at War: In Afghanistan and Beyond (Ithaca: Cornell University Press, 2008), 160.

${ }^{478}$ Ibid., 161-162.
} 
tentative evidence drawing on a rough comparison of the scope of mobilization of more centralized versus more decentralized segments of the broader insurgency suggests that, as predicted, the Mujahideen insurgency could have become a larger, faster, and even more formidable revolution had they developed a more centralized organizational structure at the national level. More research is needed to more fully substantiate this point in this case.

In sum, fragmented insurgencies have a high administrative presence and a low level of organizational centralization. As a result of this combination of traits, fragmented insurgencies are able to mobilize a significant amount of popular support at a rapid pace, but are limited in the total amount of popular support. What this means is that fragmented insurgencies are not likely to grow to as big as they otherwise might due to their poor organizational structure, but insurgencies of this sort should produce a fairly large amount of popular support-securing outputs. Fragmented insurgencies are also both easy for the state to target militarily and fairly resilient to being targeted.

\section{5 - Bureaucratic Insurgencies}

Bureaucratic insurgencies have both a high administrative presence and a high level of organizational centralization. When it comes to a rebel group's chances of victory or failure, this combination of characteristics produces two extremes. To their benefit, bureaucratic insurgencies are likely to mobilize a significant amount of popular support due to their high administrative presence and high organizational centralization. Because this type of insurgency is likely to mobilize a lot of popular support, it is likely to present a serious challenge to the state and, therefore, stands a fairly good chance of winning. But, since bureaucratic insurgencies have a large administrative presence and a high level 
of organizational centralization, they are also likely to be routinely and effectively targeted by state forces and should have, controlling for the strength of the group, a fairly minimal degree of organizational resilience in the face of state military pressure.

\section{Figure 6.4. Bureaucratic Insurgencies}

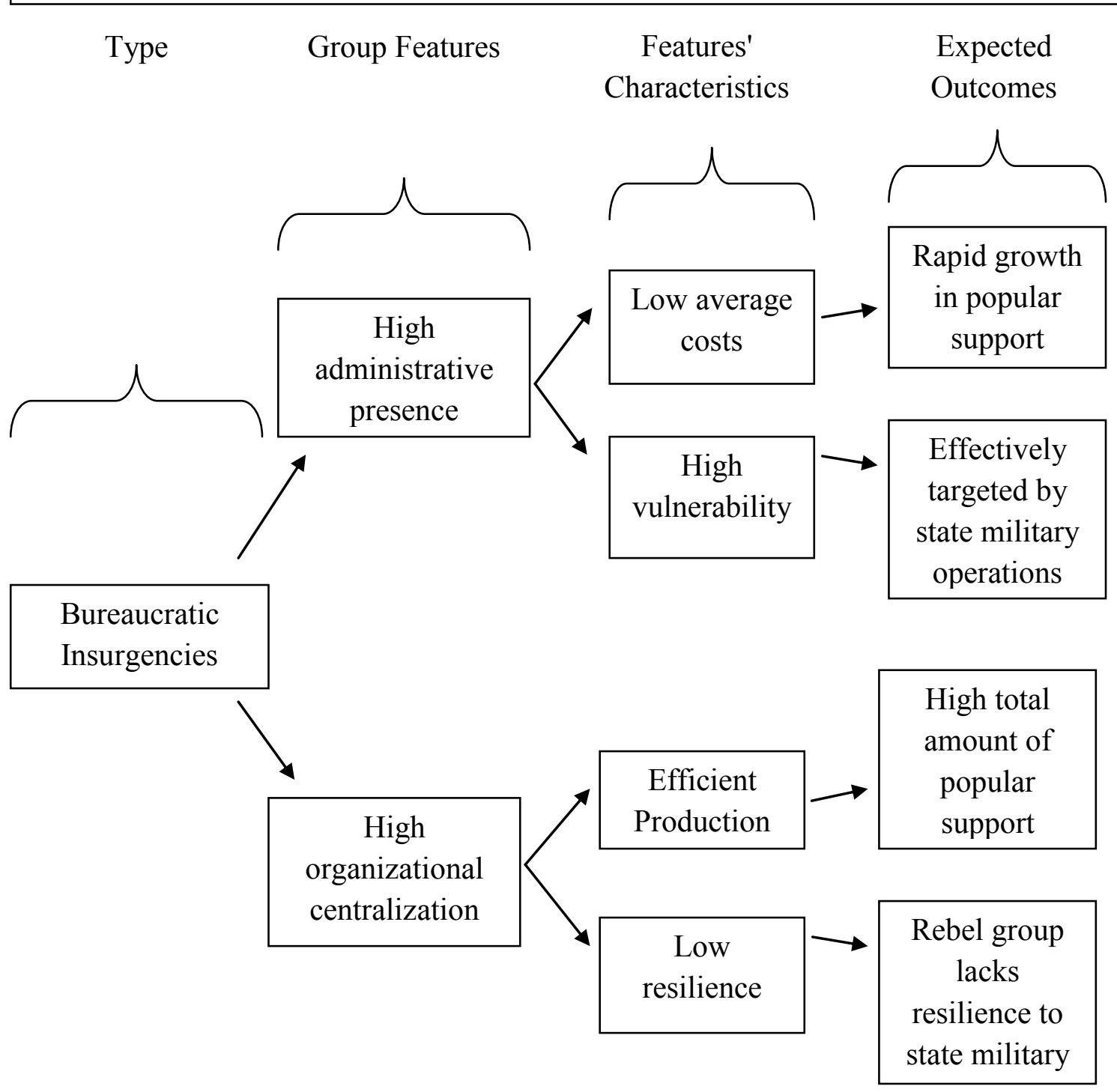

Figure 6.4 provides a summary of the general interrelationship that exists between a bureaucratic insurgency's high administrative presence and its high organizational centralization and the factors that both favourably and unfavourably affect the group's 
chances of beating, or being beaten by, the state. For the subsequent empirical example, the causal relations depicted in Figure 6.4 also clarify and provide an easy reference regarding what should likely occur within a war that involves a bureaucratic insurgency. The predictions of how the conflict should look are made in the far right-hand side of the figure. Generally, a conflict involving a bureaucratic insurgency should be intense, marked by high levels of mobilization and high levels of state violence. The insurgency should be both fairly easy to target and prone to collapse, although the EPLF did not collapse in this case.

\subsection{1 - The Eritrean People's Liberation Front in then-Ethiopia}

The Eritrean People's Liberation Front (EPLF) is a prime example of a bureaucratic insurgency, as it had both a large-scale administrative presence and a high level of organizational centralization. The EPLF fought within a very favourable mobilization context. During the time of the insurgency, what is now Eritrea was officially part of Ethiopia. Under the Ethiopian state, the population of Eritrea had failed to see much material benefit and lacked political representation. Additionally, the EPLF, which emerged in 1972 and held its first official congress in the Sahel region of northern Eritrea in 1977, benefited from the fact that it grew out of the ongoing ELF insurgency. ${ }^{479}$ The ELF had been conducting low-level resistance against the Ethiopian state since the late 1960s. The ongoing insurrection against the regime meant that the state had previously used indiscriminate coercion against the population, which pushed the people of Eritrea even further towards supporting the insurgency. The one negative factor working against

\footnotetext{
${ }^{479}$ David Pool, From Guerrillas to Government: The Eritrean People's Liberation Front (Athens: Ohio University Press, 2001), 63.
} 
the EPLF was that the population's support was split between the two insurgent groups, with some supporting the ELF and some the EPLF. This limitation on EPLF mobilization was removed in the late 1970s, when the ELF had experienced a rash of defections and the EPLF rapidly emerged as the dominant rebel organization within Eritrea. Given these favourable conditions and the bureaucratic structure of the EPLF insurgency, the insurrection eventually prevailed over the Ethiopian state and obtained independence for Eritrea, although the course of the conflict was filled with marked wartime ebbs and flows.

As a bureaucratic insurgency, the EPLF had a large and expansive administrative presence, which increased the rate at which it attracted popular support over time, as well as the total scope of its mobilization. The EPLF expanded its administrative presence by developing original, overlapping, and mutually reinforcing vertical and horizontal administrative structures, which facilitated the production of popular support-securing outputs and garnered considerable popular support in exchange. ${ }^{480}$ The EPLF expanded into a region by, in the first instance, displacing local administration and providing remunerative compensation to the population, including health services, education, labour, and effective land reform. Additionally, as the EPLF's administrative presence took root in an area, the insurgency established administrative committees of various densities, ranging from somewhat superficial people's committees to popular assemblies to more developed resistance committees. ${ }^{481}$ In addition to these political associations, the EPLF operated four hospitals, 20 clinics and 11 mobile medical teams by 1976, all with the aim of providing considerable levels of remunerative compensation to the

\footnotetext{
${ }^{480}$ Ibid., 112.

${ }^{481}$ Ibid., 119.
} 
population in insurgent-controlled areas at low average costs to the insurgency. The EPLF also implemented large-scale education programs and mass literacy campaigns within its areas of control, which acted as both a remunerative compensation output and as a vehicle for insurgent propaganda. ${ }^{482}$

By 1977, the EPLF had a fairly dense administrative presence across a significant portion of Eritrean territory, including the Highlands of the Sahel region and a large number of major cities and towns, including Nacfa, Fah, Decamare, and, importantly, Keren, which was the second largest city in Eritrea. ${ }^{483}$ The EPLF's large-scale administrative presence was advantageous for the insurgency because it meant that a lot of popular support-securing outputs could be produced and supplied to the population, reducing the average cost per unit of output. Between 1974 and 1978, popular support for the EPLF accrued at a rapid pace and bolstered the rebellion's position relative to the regime, which is consistent with the idea that the scale of the insurgency's administrative presence produced lower average costs and better margins for the insurgency ${ }^{484}$ Indeed, in 1976, the membership of the insurgency numbered around 10,000 members. ${ }^{485}$ By 1977, following the expansion of the insurgency's administrative presence into urban centres and the more expansive provision of remunerative compensation and the fuller use of preference manipulation tactics, the number of students in EPLF 'vanguard schools' that aimed at increasing the size of the insurgency was around 1,100, which means the insurgency was expanding its active membership by at least 11 percent per

\footnotetext{
${ }^{482}$ Richard Sherman, Eritrea: The Unfinished Revolution (New York: Praeger Publishers, 1980), 102-105.

${ }^{483}$ Dan Connell, Against All Odds: A Chronicle of the Eritrean Revolution (Lawrenceville: Red Sea Press, 1997), 93-108.

${ }^{484}$ David Pool, From Guerrillas to Government: The Eritrean People's Liberation Front (Athens: Ohio University Press, 2001), 103.

${ }^{485}$ Dan Connell, Against All Odds: A Chronicle of the Eritrean Revolution (Lawrenceville: Red Sea Press, 1997), 315.
} 
during this year. ${ }^{486}$ Other estimates note that the EPLF had amassed roughly 20,000 guerrilla fighters during 1978 and early $1979 .{ }^{487}$ Presumably, the number of passive and active supporters amongst the broader population that stopped short of actually joining the insurgency was far larger still. ${ }^{488}$

The EPLF's administrative presence had increased to a large enough scale by 1978 that it made the insurgency quite vulnerable to military activity by the Derg counterinsurgency. ${ }^{489}$ After rapidly expanding its administrative breadth and depth from 1974 to 1977, the EPLF insurgency, along with the ELF, faced a massive Derg counteroffensive in the summer of 1978 that was well targeted towards the location and administrative structures of the insurgency. The insurgency proved most vulnerable in the major urban centres of Eritrean territory, where it had developed an administrative presence of considerable depth in an effort to accommodate the large population base of the cities. By July 4th, 1978, the Ethiopian regime, buoyed by Soviet, Cuban, and Israeli military assistance, marshalled some 100,000 soldiers for an offensive into ELF- and EPLF- controlled territory. ${ }^{490}$ By the 21 st of July, 1978, the state forces had smashed through the ELF positions and turned its military pressure more directly onto the EPLF.

\footnotetext{
${ }^{486}$ David Pool, From Guerrillas to Government: The Eritrean People's Liberation Front (Athens: Ohio University Press, 2001), 99.

${ }^{487}$ Ibid., 145.

${ }^{488}$ I gave each of the four operational components of a rebel group's administrative presence the following values in this case: political associations (0.8), remunerative compensation infrastructure (0.8), preference manipulation capacity (0.6), geographical scope (0.3). Employing the coding procedure outlined above, these values result in a score of 0.625 for the EPLF's administrative presence. The EPLF, in short, had a large-scale administrative presence.

${ }^{489}$ The following description is based upon the firsthand account of the offensive reported by Dan Connell. See Dan Connell, Against All Odds: A Chronicle of the Eritrean Revolution (Lawrenceville: Red Sea Press, 1997), 158-177.

${ }^{490}$ Dan Connell, Against All Odds: A Chronicle of the Eritrean Revolution (Lawrenceville: Red Sea Press, 1997), 160.
} 
Between the end of July and the beginning of 1979, Derg forces had successfully targeted areas of EPLF administrative control. As the state forces advanced, they expelled the EPLF's organizational formations from most of the region's major towns and cities and had pushed the insurgency into the mountains surrounding the northern town of Nacfa, which remained the last major urban centre under the control of the insurgents. Once the military elements of the insurgency had been displaced from an area, the administrative structures of the insurgency were destroyed in detail. ${ }^{41}$ In other words, the insurgency's significant administrative presence limited the rebellion's mobility to a certain extent, and, even more importantly in this case, increased the contrast between the insurgency's organization and productive infrastructure and the surrounding population. The Derg regime was, as a result, able to target EPLF-controlled areas with significant levels of force, which destroyed most of the administrative structures that the insurgency had put into place. By early 1979 , the EPLF was heavily battered and marginalized to a small sliver of their original territory.

As a bureaucratic insurgency, the EPLF was a highly centralized organization that maintained disciplined and effective control over its membership. Essentially, "The underlying pattern [of organization]," notes David Pool, "was one of centralized control and guidance balanced by considerable scope for initiative on the part of EPLF cadres." ${ }^{492}$ The centralized structure of the EPLF was adopted fairly early on in its development. The founding membership of the EPLF, which split off of the ELF, aimed to ensure that the organizational structure of the insurgency was centralized and cohesive so as to avoid some of the factionalism and organizational limitations of the progenitor

\footnotetext{
${ }^{491}$ See Ibid., 166.

${ }^{492}$ David Pool, From Guerrillas to Government: The Eritrean People's Liberation Front (Athens: Ohio University Press, 2001), 106.
} 
group ${ }^{493}$ The EPLF's organizational structure was further centralized in 1973 in response to an internal challenge to the EPLF leadership from the so-called Manqa opposition. At this time, new organizational structures and procedures were put into place to coordinate the provision and production of health services and other forms of remunerative compensation, ultimately with an eye towards increasing the efficiency with which popular support-securing outputs were produced. Indeed, the years following this further centralization in structure, from 1974 to late 1977, was a period of significant organizational growth for the EPLF. ${ }^{494}$ In other words, the total size of the insurgency was positively affected by the organizational centralization of the EPLF, which enhanced the group's efficiency and allowed the insurgency to reach a larger overall size than would likely have otherwise been possible. ${ }^{495}$

The typological formulation of the mobilization and conflict outcome theory predicts that a bureaucratic insurgent group, such as the EPLF, should have limited organizational resilience in the face of state military pressure due to its centralized organizational structure and the consequently high level of mutual reliance between organizational subunits. In this particular case, the EPLF withstood all the military pressure that the Derg regime brought to bear and never collapsed. Since the EPLF eventually defeated the Ethiopian counterinsurgency, the insurgency could not have lost, which is what organizational collapse implies, if not means in actual point and fact. The reason for the EPLF's stunning resilience in the face of Derg military pressure hinges

\footnotetext{
493 Ibid., 55.

494 Ibid., 81.

${ }^{495}$ Based upon the criteria presented above, I coded the EPLF as having the following on the organizational components: Specialization (0.6), Coordination mechanisms (0.6), control and monitoring mechanism (0.7), hierarchy (0.8). These values result in a centralization score of 6.75, making the EPLF a highly centralized rebel group.
} 
upon, as pointed out in chapters four and five, the idea that a rebel group's capacity relative to the state conditions the amount of pressure that an insurgency of any organizational type can withstand before cascading into total collapse. To reiterate the proposition briefly, for a given organizational structure, the stronger the rebel group, the more pressure the state needs to apply in order to push the group beyond its organizational tipping point.

The EPLF was able to resist the military pressure of the counterinsurgency, as I expand upon below, because it retained and even expanded its popular support base, concentrated its forces in the Sahel region around Naqfa, which was topographically favourable to insurgent warfare, and fielded guerrilla warfare units behind the advancing Derg formations. All of these wartime dimensions essentially made the EPLF relatively capable when compared to the Derg regime. As a result, it was able to withstand the military pressure that was brought to bear against it and to eventually prevail in the conflict.

During the Derg offensives in 1978 and 1979, the Ethiopian state applied a considerable amount of pressure against both the ELF and the EPLF, with committed forces topping 100,000 soldiers during the initial campaign. ${ }^{496}$ The ELF insurgency, which was also a fairly centralized organization (although less so than the EPLF), crumbled under the pressure, although they remained active in a minor way into the first few years of the 1980s. The ELF was the initial target of the Derg offensives, was materially weaker than the EPLF, and had a fairly centralized structure, so its collapse conforms to expectations of the fate that should befall a heavily pressured, centralized

\footnotetext{
${ }^{496}$ Dan Connell, Against All Odds: A Chronicle of the Eritrean Revolution (Lawrenceville: Red Sea Press,
} 1997), 160. 
rebel group. The EPLF, however, withstood the pressure and did not collapse. During 1978 and the following offensives, the EPLF lost some 3,000 guerrilla fighters, which is a considerable amount given that the insurgency had only around 20,000 fighters at this point and time. ${ }^{497}$ Despite these losses, several factors coalesced to ensure that the EPLF retained much of its core strength and therefore retained enough capacity to resist the military pressures that were brought to bear by the counterinsurgency.

First of all, as the Derg offensives unfolded, the EPLF implemented a strategic withdrawal from most of the towns and cities that it controlled in 1977. The insurgency was able to leverage their centralized and efficient organizational structure to move large segments of the population together with the withdrawing guerrillas. ${ }^{498}$ Along with the collapse of the ELF and the migration of large swaths of the population from former ELF-controlled territory into EPLF base areas in the Sahel, the movement of the population from major urban centres of Keren and Decamhare that had previously been under EPLF control meant that the popular support base of the EPLF insurgency remained intact despite the Derg offensives. In its effect, the largely unspoiled support base allowed the EPLF to continue to replace its organizational membership and retain a large amount of its warfighting capacity. Some ELF fighters also fled the collapsing organization and joined the EPLF at this time. ${ }^{499}$

Additionally, the topography and geographical space of the Sahel region benefited the EPLF and increased its resilience in two ways. First, the Sahel region is mountainous

\footnotetext{
497 David Pool, From Guerrillas to Government: The Eritrean People's Liberation Front (Athens: Ohio University Press, 2001), 145.

${ }^{498}$ Richard Sherman, Eritrea: The unfinished Revolution (New York: Praeger Publishers, 1980), 93; David Pool, From Guerrillas to Government: The Eritrean People's Liberation Front (Athens: Ohio University Press, 2001), 144.

${ }^{499}$ Dan Connell, Against All Odds: A Chronicle of the Eritrean Revolution (Lawrenceville: Red Sea Press, 1997), 170.
} 
and inhospitable, which favoured the guerrilla fighters over the Derg forces, as the regime forces were armed with modern Soviet weaponry that could not easily navigate the terrain. The terrain, in this case, blunted the total pressure that the counterinsurgency was able to bring to bear against the EPLF's last base area in the Sahel region. Secondly, the area that the EPLF needed to defend after the end of 1978 and 1979 Derg offensives shrunk by about one third. ${ }^{500}$ Correspondingly, the amount of territory that the Derg regime needed to control expanded in proportional terms. All this meant that the EPLF had concentrated its forces in a smaller area and could marshal more force at any given point, while the Derg forces dispersed their forces and could now concentrate less force against any specific location. Together, this combination of insurgent concentration and counterinsurgent dispersion led to a relative balance of capacity that favoured the insurgency to a greater extent.

Finally, the EPLF fielded guerrilla formations to harass Derg forces behind the front lines, tie down counterinsurgent capacity, and maintain some links with the population in the newly re-occupied towns and cities. As Dan Connell puts it, "The EPLF had moved back into position throughout much of Ethiopia's exposed and thinly defended rear. The fighters were maintaining links to supporters in the occupied towns and keeping the Ethiopians off balance with a stream of commando raids and propaganda operations." Reportedly, by mid-1979, the guerrilla forces had destroyed 560 trucks and 150 armoured vehicles, all of which diminished the amount of pressure that the Derg counterinsurgents could apply against the EPLF in the Sahel.

\footnotetext{
${ }^{500}$ David Pool, From Guerrillas to Government: The Eritrean People's Liberation Front (Athens: Ohio University Press, 2001), 145.
} 
The example of the EPLF as a bureaucratic insurgency strongly supports three of the four predicted outcomes of the typological theory. The EPLF rapidly mobilized popular support due to its high administrative presence. It was also able to mobilize significant amounts of support due to its high degree of organizational centralization. At the same time, the large-scale administrative presence of the EPLF made it vulnerable to attack by counterinsurgent forces. The EPLF was, contrary to the predicted outcome, able to resist the military pressure that the Ethiopian regime brought to bear and proved to be remarkably resilient. The resilience of the EPLF in this case is attributable to the relative capacity of the insurgency in relation to the regime, which does itself conform to the full theory. The ELF, the other fairly centralized Eritrean insurgent group that was materially weaker than the EPLF, did collapse under the applied military pressure - which is consistent with the predicted outcome of the typological theory.

In sum, bureaucratic insurgencies have both a large-scale administrative presence and a high level of organizational centralization. The combination of both a large-scaled administrative presence and high organizational centralization entails that bureaucratic insurgencies can grow rapidly and to a significant size. Compared to the other types of rebel groups, bureaucratic insurgencies are likely to have the best chance of defeating the state because they can obtain a lot of popular support via the broad-based and efficient production of popular support-securing outputs. At the same time, a large-scale administrative presence means that bureaucratic insurgencies are highly vulnerable to being targeted and attacked by state forces, particularly if they are weaker than state forces. Additionally, at least when compared to an equally capable but decentralized insurgency, centralized rebel groups like a bureaucratic insurgency should have low 
organizational resilience, meaning that it is easier for the state to pressure them into organizational collapse through the application of military pressure.

\section{6 - Conclusions}

In this chapter, I also constructed a typology of rebel groups that classifies each group according the scale of the insurgency's administrative presence (either high or low) and its level of organizational centralization (either centralized or decentralized). Combining these characteristics results in four types of insurgencies: diffuse insurgencies, vanguard insurgencies, fragmented insurgencies, and bureaucratic insurgencies. The typological theory predicts that the conflict in each case should take on certain distinct processes due to the rebel group's high or low level of administrative presence and their level of organizational centralization. I tested these predictions against a case study of each type of insurgency and found that the theory was fairly accurate at predicting some of the more general trends that were found in each type of conflict. 


\section{Chapter 7: Some Brief Conclusions}

In my dissertation, I have developed what I call the mobilization and conflict outcome theory to explain why some rebel groups win and others lose. Core to the theory is the uncoupling of a rebel group's possession of popular support from the processes through which that support is mobilized. By disaggregating possession from process, the mobilization and conflict outcome theory suggests that having popular support helps an insurgency win (because the group gets stronger and more capable), but that the organizational and administrative requirements of effective mobilization hurt an insurgency's chances of success by making it more vulnerable and less resilient to state military activity (because those most effective at mobilization tend to be both based around a large-scale administrative presence and centralized).

By disaggregating the possession and the mobilization of popular support, it becomes apparent that a rebel group faces a core dilemma. It can reform organizationally and administratively in order to mobilize the greatest amount of popular support so as to stand the best chance of defeating the regime, but doing so also helps the state in its efforts at defeating the insurgency. Alternatively, an insurgency can retain the organizational and administrative characteristics that reduce the state's ability to deal with an insurgency, but doing so limits the amount of popular support that the rebellion will mobilize, which makes rebel success unlikely. Threading this needle is the realm of politics attuned to the each group's context, and, most likely, not a small amount of luck. 
In the introductory chapter, I noted that a theory purporting to explain the outcome of insurgencies should be able to render a statement on four trends. To reiterate those trends, I posited that a useful theory of conflict outcome should:

1) Be able to account for why rebel groups are winning more now than they did previously;

2) Be able to explain the drivers of the use of force within the conflict;

3) Be able to account for variation in the level of support that the population provides to the insurgency, in addition to the other relevant factors affecting conflict outcome;

4) Be able to account for how the requirements of mobilizing popular support might have an independent effect on conflict outcome.

On the first point, the mobilization and conflict outcome theory posits that rebel groups are winning more now than they did before because the conditions that favour rebel group mobilization are now more common and often more pronounced. The most obvious condition favouring mobilization is the presence of external support for rebel factions. As Chapter 5 pointed out, under more autarkic conditions, rebel groups do tend to lose and to lose even as they mobilize more popular support. As the world becomes increasingly globalized, the conditions of autarky have become very rare. Hence, insurgencies win more often. Other conditions that favour rebel group mobilization have also become more common over time, with things like growing populations and the withdrawal of colonial rule, which left weak states in its wake, likely making mobilization easier. The emergence of more favourable mobilization contexts over time 
should allow rebel groups to mobilize higher levels of support without needing to adopt as much organizational centralization or as large scale of an administrative presence.

On the second point, the mobilization and conflict outcome theory posits a clear explanation for the drivers of a state's use of force, although it is silent on what determines a rebel group's use of military means. In the theory, the direction of a state's use of force is conditioned by the scale of the rebel group's administrative presence, with a larger scaled presence making the discriminate use of force easier and a smaller presence making it harder. This element suggests the times and locations of targeted state violence will be those occasions where the insurgency has a large scale presence and that the times of more indiscriminate state violence will be the times of low administrative presence. The theory also posits that centralized groups are typically less resilient than decentralized groups, everything else being equal. When the state uses force against centralized groups, therefore, you are more likely to see it emerge victorious, while state force against a decentralized group should be less effective. In other words, the theory illustrates both the times and locations when certain types of state violence should be used and the likely effect of that violence.

On the third point, the mobilization and conflict outcome theory develops a clear framework for understanding which groups are going to be mobilizing the most popular support and which will be mobilizing the least. Given the state's degree of political exclusivity and its use of indiscriminate violence, the most popular rebel groups will be those that supply the most remunerative compensation to the people and use the most extensive preference manipulation tactics. Less popular groups, in contrast, will supply less benefits to the people and use less propaganda and coercion. 
On the final point, the mobilization and conflict outcome theory clearly links the means that a rebel group uses to secure popular support (remunerative compensation and preference manipulation tactics) with the organizational and administrative structure of the rebel group. As the core Insurgent's Dilemma suggests, these links pull the group towards higher levels of centralization and a large-scale administrative presence, but these features of a rebel group can actually harm an insurgency by reducing its resilience to state military activity and by increasing its vulnerability to being targeted. Thus, those groups that are the most effective at mobilization are also the most likely to be defeated by the regime.

The mobilization and conflict outcome theory makes some fairly strong predictions about how events should unfold. Given the data that is currently available, I have made every effort to test the theory against the evidence. These tests are certainly not without their limitations. The descriptive statistics in Chapter 5 can, at best, be characterised as indicative of the theory. The small sample size and the strong assumption about autarkic conditions mean that these test are very controlled. More, and more refined, data is needed to test the theory using a large sample. Another useful avenue would be to extrapolate more hypotheses from the theory and to test these against whatever data is available. Such tests would likely be worthwhile.

The case studies, too, are not without their own limitations. While the internal mechanics of the theory are borne out in the cases, there are still some nagging problems. First of all, the cases were selected because they fit well into the four categories of insurgency. Cases that are firmly within each category are not necessarily the strongest tests of the theory. In this sense, these are "most likely" cases, which means that the 
theory has the highest chance of being supported in the cases that I looked at. Replicating the analysis in cases that should not fit, that is, "least likely" cases could help to determine the breadth and applicability of the theory. ${ }^{501}$

Secondly, the tests are largely synchronic, measuring variation across cases rather than variation over time. The four insurgencies studied in-depth in this work chose their respective organizational structures and did not change them very much over the course of the conflict. The larger groups, such as the EPLF, the Mujahideen and, to some extent, the Shining Path, did expand their administrative presence over the course of the conflict. The use of synchronic tests is problematic in some ways as the theory has a strong dynamic element to it. Diachronic tests of a single case over time would be interesting to conduct, even if it would be difficult to assess the full theory since it is probabilistic and ultimately speaks to conflict outcome - and a group can only win or lose once.

Additionally, very refined data would be needed to test the theory over time with a single group, which creates a feasibility barrier to this sort of test.

The theory itself, while compelling overall, is also hostage (as all theories are) to the assumptions that I made in its formulation and articulation. Some of the initial assumptions, such as the idea that the people can only support the insurgency, support the state, or remain neutral, with flight not being an option, is not very realistic in practice. How population movement affects the basic story told here is an interesting question and potentially worthy of future research.

\footnotetext{
${ }^{501}$ On "most likely" and "least likely" case studies and their use and limitations, see Alexander L. George and Andrew Bennett, Case Studies and Theory Development in the Social Sciences (Cambridge: MIT University Press, 2005), 121-122.
} 
Another area where further research would be beneficial involves the assumption that rebel group production technology is constant both over time and across groups. This assumption is not particularly realistic, as some rebel groups have access to modern technologies (medical, telecommunications, and so forth) that would allow them to produce more (and better) remunerative compensation and preference manipulation tactics. What is not clear is how these new technologies would affect the basic story told here, but it plausible that modern technological advancements have likely made it easier for an insurgency to mobilize support without the need for centralized organization and a large-scale administrative presence. The most obvious case is the role of modern telecommunications, like the Internet, which allows for long-distance communication and is virtually costless. To the extent that these technologies work in this expected direction, they make rebel success more likely, although this account does not factor in the numerous countervailing actions that the state can undertake to exploit groups that rely too extensively on modern telecommunications.

Another area of further research would be to pinpoint the precise conditions under which an insurgent group is able to expand its administrative presence via incorporation of pre-existing socio-political networks rather than needing to build up its own structures in an area. Determining these conditions would allow for a more refined treatment of the idea that rebel groups that are closer to pre-existing socio-political trends are more likely to win.

The mobilization and conflict outcome theory can inform policy in some interesting ways. First of all, the core exchange relationship that governs rebel group mobilization is heavily structured and affected by the state's nature (its degree of 
exclusivity) and its actions (its degree of indiscriminate violence). Since the ease of mobilization affects the incentives that the rebel group faces when it comes to selecting an organizational form and the scale of its administrative presence, the state can either make its own counterinsurgency task easy or hard by making rebel group mobilization easy or hard. To inhibit rebel mobilization, states should refrain from using indiscriminate violence to the largest possible extent and should try to create and maintain an inclusive state structure (two processes that are far easier said than done, certainly).

Other factors also affect the mobilization context that a rebel group finds itself in. Some other these factors, such as state strength, can be directly manipulated by a regime. Stronger is better, in this case. Stronger regimes require stronger insurgencies to defeat them, which means the rebel group will need to be better at mobilization to reach a larger absolute size. State strength helps defeat an insurgency because stronger states have more resources, but it also helps by forcing the insurgency to structure itself in ways that are easier for the state to deal with.

Lastly, rebel groups need capacity to challenge a regime, but they can get capacity either from the people or from alternatives, such as illicit crops, external patrons, or lootable natural resources. The relationship between mobilization and organizational and administrative form that is presented here only emerges if the insurgency is actually trying to mobilize a lot of popular support. If substitutes to popular support are plentiful and cheap, the rebel group is less likely to adopt the sort of structures that will aid the state in its efforts to destroy the insurgency. Cutting off external funding to a rebellion and controlling the exploitation of crops and resources will limit the capacity available to 
an insurgency and force them into mobilizing the population if they want to get large enough to win. Such a move forces the insurgency into the processes discussed at length in this work and contributes to the prospect of state victory.

In short, I have argued here that rebels face a core dilemma: mobilize a lot of support to try and win but suffer a higher risk losing or remain small and hard to defeat but remain unlikely to win.

The End 


\section{Bibliography}

Adhikari, Prakash and Steven Samford. 2013. "The Nepali State and Dynamics of the Maoist Insurgency," Studies in Comparative International Development 48:4, 457-481.

Afsar, Shahid, Chris Samples, and Thomas Wood. 2008. "The Taliban: An Organizational Analysis." Military Review, 58-73.

Ahmad, Eqbal. 1982. "Revolutionary Warfare and Counterinsurgency." In Gerard Chaliand (ed.), Guerrilla Strategies: An Historical Anthology from the Long March to Afghanistan, 241-262. Berkeley: University of California Press.

Akerlof, George. 1970. "The Market for 'Lemons': Qualitative Uncertainty and the Market Mechanisms." Quarterly Journal of Economics 84:3, 488-500.

Alchian, Armen A. and Harold Demset. 1972. "Production, Information Costs, and Economic Organization." The American Economic Review 62:5, 777-795.

Anderson, Jon Lee. 2004. Guerrillas: Journeys in the Insurgent World. Toronto: Penguin Books.

Anderton, Charles H. and John R. 2009. Carter, Principles of Conflict Economics. New York: Cambridge University Press.

Arreguin-Toft, Ivan. 2001. "How the Weak Win Wars: A Theory of Asymmetric Conflict." International Security 26:1, 93-128.

Arreguin-Toft, Ivan. 2008. How the Weak Win Wars: A Theory of Asymmetric Conflict. New York: Cambridge University Press.

Asprey, Robert B. 2002. War in the Shadows: The Guerrilla in History, vol. 1. Lincoln: Backinprint.com.

Bailey, Kenneth D. 1994. Typologies and Taxonomies: An Introduction to Classification Techniques. London: Sage Publications.

Balcells, Laia and Stathis Kalyvas. 2012. "Does Warfare Matter? Severity, Duration, and Outcomes of Civil War." ICIP Working Papers 5, 7-37.

Barnett, Donald L. and Karari Njama. 1966. Mau Mau From Within: Autobiography and Analysis of Kenya's Peasant Revolt. New York: Modern Readers Paperback.

Beckett, Ian F.W. 2001. Modern Insurgencies and Counter-Insurgencies. New York: Routledge. 
Bennett, Hew. 2013. Fighting the Mau Mau: The British Army and Counter-Insurgency in the Kenya Emergency. New York: Cambridge University Press.

Berg, Ronald H. 1992. "Peasant Responses to Shining Path in Andahuaylas." In David Scott Palmer ed., Shining Path of Peru, (New York: St. Martin's Press, 1992), 83104.

Berman, Eli, Jacob N. Shapiro, and Joseph H. Felter. 2011. "Can Hearts and Minds Be Bought? The Economics of Counterinsurgency in Iraq." Journal of Political Economy 119:4, 766-819.

Blau, Peter M. and W. Richard Scott. 2003. Formal Organizations: A Comparative Approach. Stanford: Stanford University Press.

Blaydes, Lisa and Jennifer De Maio. 2010. "Spoiling the Peace? Peace Process Exclusivity and Political Violence in North-Central Africa." Civil Wars 12:1-2, 328.

Booth, John A. 1985. The End and The Beginning: The Nicaraguan Revolution. Boulder: Westview Press.

Boquerat, Gilles. 2009. "Maoism and the Ethnic Factor in the Nepalese People's War." In Laurent Gayer and Christophe Jaffrelot (eds.), Armed Militias of South Asia:

Fundamentalists, Maoists, and Separatists, 45-64. New York: Colombia University Press.

Brafman, Ori and Rod A. Backstrom. 2007. The Starfish and the Spider: The Unstoppable Power of Leaderless Organizations. Toronto: Portfolio.

Buchanan, James M. and Gordan Tullock. 2004. The Calculus of Consent: Logical Foundations of Constitutional Democracy (Indianapolis: Liberty Fund.

Burke, Jason. 2011. The 9/11 Wars. New York: Penguin Books.

Byman, D. Peter Chalk, Bruce Hoffman, William Rosenau, and David Brannan. (2001). Trends in Outside Support for Insurgent Movements. Santa Monica: RAND Corporation Publishing.

Byman, Daniel. 2006. "Do Targeted Killings Work?" Foreign Affairs 85:2, 95-105.

Chaliand, Gerard. 1982. Report from Afghanistan, Tamar Jacoby trans. New York: Viking Books.

Child, John. 1973. "Predicting and Understanding Organizational Structure." Administrative Studies Quarterly 18:2, 168-185. 
Clutterbuck, Richard. 1967. The Long, Long War: The Emergency in Malaya, 1948-1960. Toronto: Cassell \& Company, Ltd.

Coase, Ronald. 1937. "The Nature of the Firm." Economica 4:16, 386-405.

Coates, John. 1992. Suppressing Insurgency: An Analysis of the Malayan Emergency, 1948- 1954. Boulder: Westview Press.

Collier, Paul and Anke Hoeffler. 2004. "Greed and grievance in civil war." Oxford Economic Papers 56:4, 563-595.

Connable, Ben, and Martin Libicki. 2010. How Insurgencies End. Santa Monica: RAND Corporation.

Connell, Dan. 1997. Against All Odds: A Chronicle of the Eritrean Revolution. Lawrenceville: Red Sea Press.

Crawford, Oliver. 1958. The Door Marked Malaya. Bungay: Richard Clay and Company, Ltd.

Davison, W.P. 1967. "Some Observations on Viet Cong Operations in the Villages." RAND Research Memorandum, RM-5267/2-ISA/ARPA.

De Votta, Neil. 2004. Blowback: Linguistic Nationalism, Institutional Decay, and Ethnic Conflict in Sri Lanka. Stanford: Stanford University Press.

DiMaggio, Paul J. and Walter W. Powell. 1983. "The Iron Cage Revisited: Institutional Isomorphism and Collective Rationality in Organizational Fields." American Sociological Review 48:2, 147-160.

Dinegar, Wilbur W. 1967. "The 'Long March' As Extended Guerrilla Warfare." In Franklin Mark Osanka (ed.), Modern Guerrilla Warfare, 147-158. New York: The Free Press.

Dix, Robert H. 1984. "Why Revolutions Succeed \& Fail." Polity 16:3, 423-446.

Dorronsoro, Gilles. 2005. Revolution Unending: Afghanistan, 1979 to the Present. New York: Columbia University Press.

Doty, D. Harold and William H. Glick. 1994. "Typologies as a Unique Form of Theory Building: Toward Improved Understanding and Modeling." Academy of Management Review 19:2, 230-251. 
Downes, Alexander B. 2007. "Draining the Sea by Filling the Graves: Investigating the Effectiveness of Indiscriminate Violence as a Counterinsurgency Strategy." Civil Wars 9:4, 420-444.

Dumville, James C. and Franciso A. Torano. 1997. "Division of Labor, Efficient? Empirical Evidence to Support the Argument," SAM Advanced Management Journal 62:2, 16-20.

Early, Bryan R. 2006. "'Larger than a Party, Yet Smaller than a State."' World Affairs $168: 3,115-128$.

Elliot, David W.P. 2007. The Vietnamese War: Revolution and Social Change in the Mekong Delta, 1930-1975. Armonk: M.E. Sharpe.

Elster, Jon. 1998. "A Plea for Mechanisms." In Peter Hedstrom and Richard Swedberg (eds.), Social Mechanisms: An Analytical Approach to Social Theory, 45-73. Cambridge: Cambridge University Press.

Englehart, Neil A. 2010. "A Tale of Two Afghanistans: Comparative Governance and Insurgency in the North and the South." Asian Survey 50:4, 735-758.

Etzioni, Amitai. 1975. A Comparative Analysis of Complex Organizations. New York: The Free Press.

Fair, C. Christine. 2005. "Diasproa Involvement in Insurgencies: Insights From the Khalistan and Tamil Eelam Movements." Nationalism and Ethnic Politics 11:1, 125-156.

Fearon, James D. and David Laitin. 2003. "Ethnicity, Insurgency, and Civil War." The American Political Science Review 97:1, 75-90.

Fearon, James D. 2005. "Primary Commodity Exports and Civil War." The Journal of Conflict Resolution 49:4, 483- 507.

Flanigan, Shawn Teresa. 2008. "Nonprofit Service Provision by Insurgent Organizations: The Cases of Hizballah and the Tamil Tigers." Studies in Conflict and Terrorism 31:6, 499-519.

Gaip, Vo Nguyen. 1962. People's War, People's Army: The Viet Cong Insurrection Manual for Underdeveloped Countries. New York: Bantam Books.

Gall, Norman. 1965. "Venezuela and the Continental Revolution." The New Leader 48, 3-7.

Galula, David. 2006. Counterinsurgency Warfare: Theory and Practice. Westport: Praeger Security International. 
Galula, David. 2006. Pacification in Algeria, 1956-1958. Santa Monica: RAND Corporation.

Garfinkel, Michelle R. and Stergios Skaperdas. 2007. "Economics of Conflict: An Overview." In Todd Sandler and Keith Hartley (eds.), Handbook of Defense Economics, Vol. 2, 649-709. New York: Elsevier.

George, Alexander L. and Andrew Bennett. 2005. Case Studies and Theory Development in the Social Science. Cambridge: MIT Press.

Gerring, John. 2012. Social Science Methodology: A Unified Framework. New York: Cambridge University Press, 61.

Gibson, James, John Ivancevich, and James Donnelly. 2006. Organizations: Behaviours, Structures, Processes. Toronto: McGraw-Hill.

Gillespie, Richard. 1986. "The Urban Guerrilla In Latin America." In Noel O'Sullivan (ed.), Terrorism, Ideology, and Revolution, 150-177. Brighton: Wheatsheaf Books, LTD.

Giustozzi, Antonio. 2000. War, Politics and Society in Afghanistan, 1978-1992. Washington: Georgetown University Press.

Giustozzi, Antonio. 2008. Koran, Kalashnikov and Laptop: The Neo-Taliban Insurgency in Afghanistan. New York: Columbia University Press.

Gonzales, Jose E. 1992. "Guerrillas and Coca in the Upper Huallaga Valley." In David Scott Palamer (ed.), Shining Path of Peru, 105-126. New York: St. Martin's Press.

Gooding, Richard Z. and John Wagner III. 1985. "A Meta-Analytic Review of the Relationship between Size and Performance: The Productivity and Efficiency of Organizations and their Subunits," Administrative Science Quarterly 30:4, 462481.

Goodwin, Jeff. 1997. "State-Centered Approaches to Social Revolutions: Strengths and Limitations of a Theoretical Tradition." In John Foran (ed.), Theorizing Revolutions, 11-37. London: Routledge.

Goodwin, Jeff. 2003. No Other Way Out: States and Revolutionary Movements, 1945 1991. Cambridge: Cambridge University Press.

Goldman, Ogen. 2013. "The Importance of Voluntary Associations For Guerrilla Movements." Studies in Conflict and Terrorism 36:10, 789-818. 
Greenhill, Kelly M, and Paul Staniland. 2007. "Ten Ways to Lose at Counterinsurgency." Civil Wars 9:4, 402-419.

Grundy, Kenneth W. 1971. Guerrilla Struggle in Africa: An Analysis and Preview. New York: Grossman Publishers.

Grynkewich, Alexus G. 2008. "Welfare as Warfare: How Violent Non-State Groups Use Social Services to Attack the State." Studies in Conflict and Terrorism 31:4, 350370 .

Guevara, Ernesto 'Che'. 1998. Guerrilla Warfare. Lincoln: Bison Books.

Hafez, Mohammed M. and Quintan Wikorowicz. 2004. "Violence as Contention in the Egyptian Islamic Movement." In Quintan Wiktorowicz (ed.), Islamic Activism: a Social Movement Theory Approach, 61-88. Indianapolis: Indiana University Press.

Hardin, Russell. 1995. One for All: The Logic of Collective Action. Princeton: Princeton University Press.

Hechter, Michael. 1988. Principles of Group Solidarity. Berkeley: University of California Press.

Heggoy, Alf Andrew. 1972. Insurgency and Counterinsurgency in Algeria. Bloomington: Indiana University Press.

Helfstein, Scott. 2009. "Governance of Terror: New Institutionalism and the Evolution of Terrorist Organizations." Public Administration Review 69:4, 727-739.

Hendrix, Cullen S. 2011. "Head for the Hills? Rough Terrain, State Capacity, and Civil War Onset." Civil Wars 13:4, 345-370.

Hirshleifer, Jack. 1995. "Theorizing About Conflict." In Keith Hartley and Todd Sandler (eds.), Handbook of Defence Economics, Vol. 1, 165-189. New York: Elsevier.

Horowitz, David L. 2000. Ethnic Groups in Conflict. Berkeley: University of California Press.

Horne, Alistair. 2006. A Savage War of Peace: Algeria, 1954-1962. New York: New York Review of Books.

Humphreys, Macartan. 2005. "Natural Resources, Conflict, and Conflict Resolution: Uncovering Mechanisms." Journal of Conflict Resolution 49:4, 508-537. 
Humphreys, Macartan and Jeremy M. Weinstein. 2008. "Who Fights? The Determinants of Participation in Civil War." American Journal of Political Science 52:2, 436455 .

Jardine, Eric. 2009. "Why Time Works against a Counterinsurgency." Journal of Military and Strategic Studies 11:4, 1-34

Jardine, Eric. 2011. "The Influence of Military Materiel on Tactics and Strategy in Counterinsurgency: A Case of British Malaya." Defence Studies 11:4, 636-657.

Jardine, Eric. 2012. "Population-Centric Counterinsurgency and the Movement of Peoples." Small Wars and Insurgencies 23:2, 264-294.

Jardine, Eric. 2012. "Controlling Territory and Population during Counterinsurgency: State Security Capacity and the Costs of Power Projection." Civil Wars 14:2, 228253.

Jardine, Eric. 2012. "The Tacit Evolution of Coordination and Strategic Outcomes in Highly Fragmented Insurgencies: Evidence from the Soviet War in Afghanistan." Journal of Strategic Studies 35:4, 541-572.

Jensen, Michael C. and William H. Meckling. 1976. "Theory of the Firm: Managerial Behavior, Agency Costs and Ownership Structure." Journal of Financial Economics 3:4, 305-360.

Johns, Gary and Alan M. Saks. 2005. Organizational Behaviour: Understanding and Managing Life at Work. Toronto: Pearson/ Prentice-Hall.

Johnston, Patrick B. 2008. "The Geography of Insurgent Organizations and its Consequences for Civil War: Evidence from Liberia and Sierra Leone." Security Studies 17:1, 107-137.

Johnston, Patrick B. 2012. "Does Decapitation Work?: Assessing the Effectiveness of Leadership Targeting in Counterinsurgency Campaigns." International Security $36: 4,47-79$.

Jones, Gregg R. 1989. Red Revolution: Inside the Philippine Guerrilla Movement. Boulder: Westview Press.

Jordan, Jenna. 2009. "When Heads Roll: Assessing the Effectiveness of Leadership Decapitation." Security Studies 18:4, 719-755.

Kafoglis, Milton Z. and Richard J. Cebula. 1981. "The Buchanan-Tullock Model: Some Extensions." Public Choice 36:1, 179-186. 
Kalyvas, Stathis N. 2004. "The Paradox of Terrorism in Civil War." Journal of Ethics $8: 1,97-138$.

Kalyvas, Stathis N. and Matthew Adam Kocher. 2007. "How 'Free' is Free Riding in Civil Wars? Violence, Insurgency, and the Collective Action Problem." World Politics 59:2, 177-216.

Kalyvas, Stathis N. 2009. The Logic of Violence in Civil Wars. New York: Cambridge University Press.

Karau, Steven J. and Kipling D. Williams. 1993. "Social Loafing: A Meta-Analytical Review and Theoretical Integration." Journal of Personality and Social Psychology 65:4, 681-706.

Kasfir, Nelson. 2005. "Guerrillas and Civilian Participation: The National Resistance Army in Uganda, 1981-1986." The Journal of Modern African Studies 43:2 (June 2005), 272.

Kataoka, Tetsuya. 1974. Resistance and Revolution in China: The Communists and the Second United Front. Berkeley: University of California Press.

Kenny, Paul D. 2010. "Structural Integrity and Cohesion in Insurgent Organizations: Evidence from Protracted Conflicts in Ireland and Burma." International Studies Review 12:4, 533-555.

Kerkvliet, Benedict J. 2002. The Huk Rebellion: A Study of Peasant Revolt in the Philippines. New York: Rowman \& Littlefield Publishers, Inc.

Kilberg, Joshua. 2012. "A Basic Model Explaining Terrorist Group Organizational Structure," Studies in Conflict and Terrorism 35:11, 810-830.

Kilberg, Joshua. 2012. Organizing for Destruction: How Organizational Structure Affects Terrorist Group Behaviour. Ottawa: Unpublished Ph.D. Dissertation.

Kilcullen, David. 2009. The Accidental Guerrilla: Fighting Small Wars in the Midst of Big Ones. New York: Oxford University Press.

Kilcullen, David. 2010. Counterinsurgency. New York: Oxford University Press.

Kim, Ilpyong J. 1973. The Politics of Chinese Communism: Kiangsi Under the Soviets. Berkeley: University of California Press.

King, Gary, Robert O. Keohane, and Sidney Verba. 1994. Designing Social Inquiry: Scientific Inference in Qualitative Research. Princeton: Princeton University Press. 
Kissinger, Henry. 1969. "The Viet Nam Negotiations." Foreign Affairs 47:2, 211-234.

Kleiman, Mark A.R. 2009. When Brute Force Fails: How to Have Less Crime and Less Punishment. Princeton: Princeton University Press.

Kohl, James and John Litt. 1974. Urban Guerrilla Warfare in Latin America. Cambridge: The MIT Press.

Kriger, Norma J. 2008. Zimbabwe's Guerrilla War: Peasant Voices. New York: Cambridge University Press.

Kydd, Andrew H. and Barbara F. Walter. 2006. "The Strategies of Terrorism." International Security 31:1, 49-80.

Latane, Bibb, Kipling Williams, and Stephen Harkins. 1979. "Many Hands Make Light the Work: The Causes and Consequences of Social Loafing." Journal of Personality and Social Psychology 37:6, 822-832.

Lawrence, T.E. 2008. Seven Pillars of Wisdom. London: Vintage Books.

Leites, Nathan, and Charles Wolf Jr, 1970. Rebellion and Authority: An Analytic Essay on Insurgency Conflict. Santa Monica: RAND Corporation.

Lichbach, Mark Irving. 1987. "Deterrence or Escalation? The Puzzle of Aggregate Studies of Repression and Dissent." Journal of Conflict Resolution 31:2, 266-297.

Lichbach, Mark Irving. 2009. The Rebel's Dilemma. Ann Arbour: University of Michigan Press.

Lilja, Jannie. 2009. "Trapping Constituents or Winning Hearts and Minds? Rebel Strategies to Attain Constituent Support in Sri Lanka." Terrorism and Political Violence 21:2, 306-326.

Lundry, Chris, Steven R. Corman, R. Bennett Furlow, and Kirk W. Errickson. 2012. "Cooking the Books: Strategic Inflation of Casualty Reports by Extremists in the Afghanistan Conflict." Studies in Conflict and Terrorism 35:5, 369-381.

Lyall, Jason, and Isaiah Wilson III. (2009). "Rage Against the Machines: Explaining Outcomes in Counterinsurgency Warfare," International Organization 63:1, 67106.

Mack, Andrew J.R. 1975. "Why Big Nations Lose Small Wars: The Politics of Asymmetric Conflict," World Politics 27:2, 175-200.

Maloba, Wunyavari O. 1993. Mau Mau and Kenya: An Analysis of a Peasant Revolt. Indianapolis: Indiana University Press. 
Malthaner, Stefan. 2011. Mobilizing the Faithful: Militant Islamist Groups and Their Constituencies. New York: Campus Verlag.

Mampilly, Zachariah Cherian. 2011. Rebel Rulers: Insurgent Governance and Civilian Life During War. Ithaca: Cornell University Press.

Mankiw, N. Gregory, Ronald D. Kneebone, Kenneth J. McKenzie, and Nicolas Rowe. 2008. Principles of Microeconomics, 4th ed. Toronto: Thomson Nelson.

Mann, Michael. 1984. "The Autonomous Power of the State: Its Origins, Mechanisms and Results." Archives Européennes de Sociologie 25, 185-213

March, James and Herbert Simon. 1993. Organizations. Oxford: Blackwell Publishing.

Markel, Wade. 2006. "Draining the Swamp: The British Strategy of Population Control." Parameters 36:1, 35-48

Mason, T. David and Dale A. Krane. 1989. "The Political Economy of Death-Squads: Toward a Theory of the Impact of State-Sanctioned Terror." International Studies Quarterly 33:2, 175-198.

McClintock, Cynthia. 1998. Revolutionary Movements in Latin America. Washington: United States Institute of Peace Press.

McCormick, Gordan H. 1990. The Shining Path and the Future of Peru. Santa Monica: RAND Corporation.

McCormick, Gordon H., Steven B. Horton, and Lauren A Harrison. (2007). "Things Fall Apart: The Endgame Dynamics of Internal Wars," Third World Quarterly 28:2, 321-367.

McKenna, Thomas M. 1998. Muslim Rulers and Rebels: Everyday Politics and Armed Separatism in the Southern Philippines. Berkely: University of California Press.

McLauchlin, Theodore. 2010. "Loyalty Strategies and Military Defection in Rebellion." Comparative Politics 42:3, 333-350.

McNamara, Robert. 1993. "Actions Recommended For Vietnam." In George C. Herring (ed.), The Pentagon Papers: Abridged Edition, 159-168. New York: McGrawHill.

Migdal, Joel S. 1974. Peasants, Politics, and Revolution: Pressures towards Political and Social Change in the Third World. Princeton: Princeton University Press. 
Miller, Gary J. 2002. Managerial Dilemmas: The Political Economy of Hierarchy. Cambridge: Cambridge University Press.

Moe, Terry. 1984. "The New Economics of Organization." American Journal of Political Science 28:4, 739-777.

Moore, Will H. 1998. "Repression and Dissent: Substitution, Context, and Timing," American Journal of Political Science 42:3, 851-873.

Morrison, Wilbur H. 1990. The Elephant \& the Tiger: The Full Story of the Vietnam War. New York: Hippocrene Books.

Morselli, Carlo, Cynthia Giguere, and Katia Petit. 2007. "The Efficiency/Security Tradeoff in Criminal Networks." Social Networks 29:1, 143-153.

Mortimer, Rex. 1974. "Traditional Modes and Communist Movements: Change and Protest in Indonesia." In John Wilson Lewis (ed.), Peasant Rebellion and Communist Revolution in Asia, 99-124. Stanford: Stanford University Press.

Moss, Robert. 1972. Urban Guerrillas: The New Face of Political Violence. London: Temple Smith.

Mryman, A., A.D. Breadsworth, E.T. Keil, and J. Ford. 1983. "Organizational Size and Specialization," Organizational Behaviour 4:3, 271-277.

Olsen, Mancur. 1971. The Logic of Collective Action: Public Goods and the Theory of Groups. Cambridge: Harvard University Press.

O'Neill, Bard. 1990. Insurgency and Terrorism: Insider Modern Revolutionary Warfare. Dulles: Brassey's, Inc.

Palmer, David Scott. 2007. "The Revolutionary Terrorism of Peru's Shining Path." in Martha Crenshaw (ed.), Terrorism in Context, 249-310. Pennsylvania: The Pennsylvania State University Press.

Papagos, Alexander. 1967. "Guerrilla Warfare." In Franklin Mark Osanka (ed.), Modern Guerrilla Warfare, 228-244. New York: The Free Press.

Peterson, Roger D. 2006. Resistance and Rebellion: Lessons From Eastern Europe. Cambridge: Cambridge University Press.

Pike, Douglas. 1968. The Vietcong: The Organization and Techniques of the National Liberation Front of South Vietnam. Cambridge: MIT University Press.

Pool, David. 2001. From Guerrillas to Government: The Eritrean People's Liberation Front. Athens: Ohio University Press. 
Popkin, Samuel L. 1979. The Rational Peasant: The Political Economy of Rural Society in Vietnam. Berkeley: University of California Press.

Powell, Walter. "Neither Market nor Hierarchy: Network Forms of Organization." Research in Organizational Behavior 12, 295-336.

Prendergast, Canice. 1999. "The Provision of Incentives in Firms." Journal of Economic Literature 37:1, 7-63.

Pugh, D.S., D.J. Hickson, C.R. Hinings, and C. Turner. 1968. "Dimensions of Organizational Structure," Administrative Science Quarterly 13:1, 65-105.

Race, Jeffrey. 2010. War Comes to Long An: Revolutionary Conflict in a Vietnamese Province. Berkeley: University of California Press.

Radu, Michael and Vladimir Tismaneanu. 1990. Latin American Revolutionaries: Groups, Goals, Methods. Washington: Pergamon-Brassey's.

Ragin, Charles. 1987. The Comparative Method: Moving Beyond Qualitative and Quantitative Strategies. Berkeley: University of California Press.

Ragin, Charles . 2000. Fuzzy-Set Social Science. Chicago: University of Chicago Press.

Record, Jeffrey. 2009. Beating Goliath: Why Insurgencies Win. Washington: Potomac Books, Inc.

Reno, William. 1993. "Foreign Firms and the Financing of Charles Taylor's NPFL." Liberian Studies Journal 18:2, 175-188.

Rochlin, James F. 2003. Vanguard Revolutionaries in Latin America: Peru, Colombia, Mexico. Boulder: Lynne Rienner Publishers.

Ross, Michael. 2004. "How Do Natural Resources Influence Civil War? Evidence from Thirteen Cases." International Organization 58:1, 35-67.

Rudner, Martin. 2010. "Hizbullah: An Organizational and Operational Profile," International Journal of Intelligence and Counterintelligence 23:2, 226-246.

Salehyan, Idean. 2007."Transnational Rebels: Neighboring States as Sanctuary for Rebel Groups," World Politics 59:2, 217-242.

Sanin, Francisco Gutierrez and Antonio Giustozzi. 2010. "Networks and Armies: Structuring Rebellion in Colombia and Afghanistan," Studies in Conflict and Terrorism 33:9, 836- 853. 
Shapiro, Jacob N. 2013. The Terrorist Dilemma: Managing Violent Covert Organizations. Princeton: Princeton University Press.

Schelling, Thomas C. 1966. Arms and Influence. New Haven: Yale University Press.

Schneider, Carsten Q. and Claudius Wagemann. 2012. Set-Theoretic Methods for the Social Sciences: A Guide to Qualitative Comparative Analysis. New York: Cambridge University Press.

Schulze, Kirsten E. 2004. "The Free Aceh Movement (GAM): Anatomy of a Separatist Organization." Policy Studies 2, 1-76.

Sharma, Sudheer. "The Maoist Movement: An Evolutionary Perspective." In Michael Hutt (ed.), Himalayan 'People's War': Nepal's Maoist Rebellion, 38-57. London: Hurst \& Company.

Sherman, Richard. 1980. Eritrea: The Unfinished Revolution. New York: Praeger Publishers.

Shultz, Richard. 1978. "Breaking the Will of the Enemy During the Vietnam War: The Operationalization of the Cost-Benefit Model of Counterinsurgency Warfare." Journal of Peace Research 15:2, 109-129.

Shultz, Richard. 1979. "Coercive Force and Military Strategy: Deterrence Logic and the Cost-Benefit Model of Counterinsurgency Warfare." Political Research Quarterly $32: 4,444-466$.

Sinno, Abdulkader H. 2008. Organizations at War: In Afghanistan and Beyond. Ithaca: Cornell University Press.

Skocpol, Theda. 2008. States and Social Revolutions: A Comparative Analysis of France, Russia, and China. Cambridge: Cambridge University Press.

Smith, Adam. 1998. The Wealth Of Nations. New York: Oxford University Press.

Snow, Edgar. 1972. Red Star Over China. Harmondsworth: Penguin Books.

Staniland, Paul. 2012. "Organizing Insurgency: Networks, Resources, and Rebellion in South Asia," International Security 37:1, 142-177.

Staniland, Paul. 2014. Networks of Rebellion: Explaining Insurgent Cohesion and Collapse. Ithaca: Cornell University Press.

Steiner, Ivan D. 1972. Group Processes and Productivity. New York: Academic Press. 
Strong, Simon. 1992. Shining Path: Terror and Revolution in Peru. New York: Times Books.

Tarazona-Sevillano, Gabriela. 1990. Sendero Luminoso and the Threat of Narcoterrorism. New York: Praeger.

Tarazona-Sevillano, Gabriela. 1992. "The Organization of Shining Path." In David Scott Palmer ed., Shining Path of Peru, 171-190. New York: St. Martin's Press.

Tarrow, Sidney. 1994. Power in Movement: Social Movements, Collective Action, and Politics. Cambridge: Cambridge University Press.

Taruc, Luis. 1975. Born of the People. Westport: Greenwood Press.

Taylor, Lewis. 2006. Shining Path: Guerrilla Warfare in Peru's Northern Highlands, 1980-1997. Liverpool: Liverpool University Press.

Thayer, Thomas C. 1977. "Patterns of the French and American Experience In Vietnam." In W. Scott Thompson and Donaldson D. Frizzell (eds.), The Lessons of Vietnam, 17-38. New York: Crane, Russak, and Co.

Thayer, Thomas C. 1977. "We Could Not Win the War of Attrition We Tried to Fight." In W.Scott Thompson and Donaldson D. Frizzell (eds.), The Lessons of Vietnam, 85-92. New York: Crane, Russak, and Co.

Tilly, Charles. 1974. "Town and Country in Revolution." In John Wilson Lewis (ed.), Peasant Rebellion and Communist Revolution in Asia, 271-302. Stanford: Stanford University Press.

Tilly, Charles. 2008. Contentious Performances. New York: Cambridge University Press.

Todaro, Michael P. and Stephen C. Smith. 2009. Economic Development 10th ed. New York: Pearson, Addison Wesley.

Toft, Monica Duffy. 2005. The Geography of Ethnic Violence: Identity, Interests, and the Indivisibility of Territory. Princeton: Princeton University Press.

Treistman, Jeffrey. 2012. "Home Away From Home: Dynamics of Counterinsurgency Warfare," Comparative Strategy 31:3, 235-252.

Trinquier, Roger. 2006. Modern Warfare: A French View of Counterinsurgency. Westport: Praeger Security International.

Tripier, Philippe. 1972. Autopsie de La Guerre D'Algerie. Paris: Editions France-Empire. Tse-tung, Mao. 2001. On Protracted War. Honolulu: University of the Pacific Press. 
Tse-tung, Mao. 2005. On Guerrilla Warfare, Samuel B. Griffith trans. Mineola: Dover Publications.

US Army and Marine Corps Field Manual, FM 3-24. 2007. Counterinsurgency. Chicago: University of Chicago Press.

Van Creveld, Martin. 2008. The Changing Face of War: Combat from the Marne to Iraq . New York: Ballantine Books.

Van Evera, Stephen. 1997. Guide to Methods for Students of Political Science. Ithaca: Cornell University Press.

Viterna, Jocelyn S. 2006. "Pulled, Pushed and Persuaded: Explaining Women's Mobilization into the Salvadoran Guerrilla Army." American Journal of Sociology 112:1, 1-45.

Walt, Stephen M. 2005. "The Relationship between Theory and Policy in International Relations." Annual Review of Political Science 8, 23-48.

"We Came From Allah and to Him We Return," Free Aceh Times, (no date). Accessed online at: http://www.achehtimes.com/news2002/syafie/, accessed on December 24, 2012.

Weinstein, Jeremy M. 2009. Inside Rebellion: The Politics of Insurgency Violence. New York: Cambridge University Press.

Whitehead, Alfred North. 1926. Science and the Modern World. Cambridge: Cambridge University Press.

Wickham-Crowley, Timothy P. 1987. "The Rise (And Sometimes Fall) of Guerrilla Governments in Latin America." Sociological Forum 2:3, 473-499.

Wickham-Crowley, Timothy P. 1991. Exploring Revolution: Essays on Latin American Insurgency and Revolutionary Theory. Armonk: M.E. Sharpe, Inc.

Wickham-Crowley, Timothy P. 1993. Guerrillas and Revolutions in Latin America: a Comparative Study of Insurgents and Regimes since 1956. Princeton: Princeton University Press.

Wood, Elisabeth Jean. 2003. Insurgent Collective Action and Civil War in El Salvador. New York: Cambridge University Press.

Wood, Reed M. "Rebel Capability and Strategic Violence against Civilians." Journal of Peace Research 47:5, 601-614. 
Wou, Odoric Y.K. 1994. Mobilizing the Masses: Building Revolution in Henan. Stanford: Stanford University Press.

Young, John. 2006. Peasant Revolution in Ethiopia: The Tigray People's Liberation Front, 1975-1991. New York: Cambridge University Press.

Yousaf, Mohammad and Mark Adkin. 2009. The Battle for Afghanistan: The Soviets Versus the Mujahideen during the 1980s. Barnsley: Pen and Sword. 